\title{
VALOR ECONÔMICO DA ÁGUA PARA IRRIGAÇÃO NO SEMI-ÁRIDO CEARENSE
}

\author{
JOSÉ CÉSAR VIEIRA PINHEIRO \\ Engenheiro Agrônomo
}

Orientador: Prof. Dr. RICARDO SHIROTA

Tese apresentada à Escola Superior de Agricultura "Luiz de Queiroz", Universidade de São Paulo, para obtenção do título de Doutor em Ciências, Área de Concentração: Economia Aplicada.

PIR A C I C A B A

Estado de São Paulo - Brasil

Fevereiro de 1998 
Pinheiro, José César Vieira

Valor econômico da água para irrigação no semi-árido cearense / José César Vieira Pinheiro. - - Piracicaba, 1998.

$195 \mathrm{p}$.

Tese (doutorado) - - Escola Superior de Agricultura Luiz de Queiroz, 1998. Bibliografia.

1. Água 2. Água de irrigaçăo 3. Aspecto econômico 4. Economia aplicada 5. Irrigação 6. Seca l. Título 


\section{VALOR ECONÔMICO DA ÁGUA PARA IRRIGAÇÃO NO SEMI-ÁRIDO CEARENSE}

JOSÉ CÉSAR VIEIRA PINHEIRO

Aprovada em: 29.05.1998

Comissão julgadora

Prof. Dr. RICARDO SHIROTA

ESALQ/USP

Prof. Dr. PAULO FERNANDO CIDADE DE ARAÚJO ESALQ/USP

Prof. Dr. GERALDO SANT'ANA DE CAMARGO BARROS ESALQ/USP

Prof. Dr. JOÃO FERNANDO MARQUES EMBRAPA

Prof. Dr. PAULO EDGARD NASCIMENTO DE TOLEDO

IEA-SP

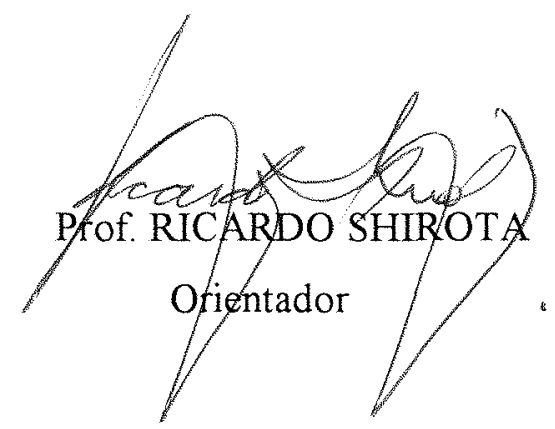


Aos que me são mais caros: meus pais José e Irene; meus irmãos Araujinho e Liduina; meus sogros Raimundo e Ana.

ofereço

Aos meus amores: minha esposa Eunice e meus filhos César Jr. e Andréa. dedico 


\section{AGRADECIMENTOS}

É com o sentimento de gratidão que manifesto o meu reconhecimento às seguintes pessoas e intituições, por suas contribuições à elaboração deste trabalho:

Agradeço ao prof. Ricardo Shirota, pela orientação segura, argúcia e inteligência incomum, além de ter sido o principal mentor desta pesquisa; agradeço ao prof. Paulo Cidade, por me indicar os rumos certos nos meus grandes momentos de indecisão, que não foram poucos, guiado por sua vasta cultura e sensibilidade humana; agradeço ao prof. Geraldo Sant'Ana, que por sua reconhecida capacidade intelectual, aparecia com sugestões sempre lúcidas e esclarecedoras daqueles pontos-chave que para mim eram tão obscuros.

Agradeço também aos professores João Marques da EMBRAPA e Paulo Toledo do IEA, pelas palavras de incentivo e valiosas críticas e sugestões apresentadas por ocasião da defesa desta tese. Gostaria também de estender meus agradecimentos:

-Aos demais professores e funcionários do Departamento de Economia e Sociologia Rural da ESALQ/USP, por promoverem um ambiente de companheirismo, dedicação e trabalho;

- À Coordenação de Aperfeiçoamento de Pessoal de Ensino Superior (CAPES), através do Programa de Incentivo à Capacitação de Docentes (PICD), pelo apoio financeiro e pontualidade, sem os quais este trabalho não teria sido realizado;

-À Universidade Federal do Ceará por ter me proporcionado este curso, especialmente aos professores, Ahmad Saeed Khan, Irles Mayorga e José Aluísio Pereira; -Ao presidente da Cooperativa dos Irrigantes do Projeto Curu-Paraipaba, Sr. José Francisco de Souza, por ter facilitado e me oferecido todas as condições para a coleta de dados;

-Aos professores Manuel Osório de Lima Viana e Patrícia Veronica Pinheiro Sales, pelas discussões úteis na etapa final deste trabalho;

-À minha esposa Eunice, que além do meu reconhecimento pelo apoio em 
todas as fases da tese, apresento minhas desculpas pelos longos períodos em que eu estive ausente de casa, especialmente aos meus filhos César Jr. e Andréa, pelo tempo em que fomos privados do convívio nos melhores momentos de suas vidas; e,

-A todos os colegas de curso, pelo companheirismo sempre presente e solidariedade nos momentos mais dificeis. 


\section{SUMÁRIO}

\section{Página}

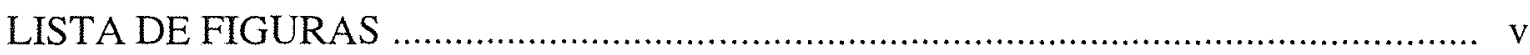

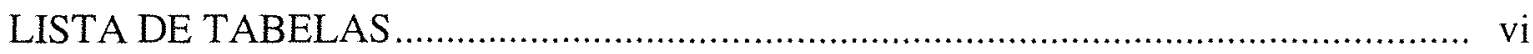

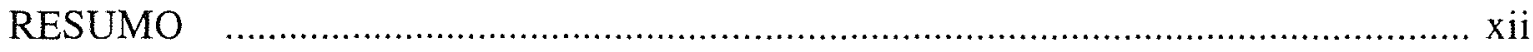

SUMMARY

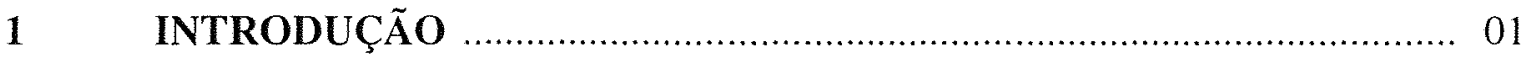

1.1 A Política de Combate as Secas ……..................................................... 03

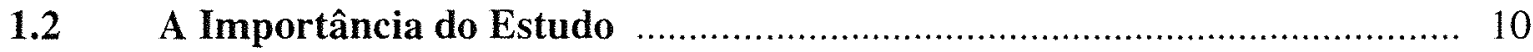

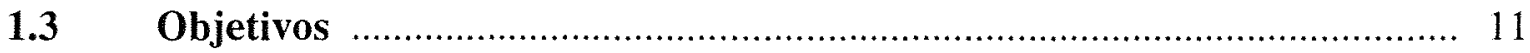

2 OS RECURSOS HÍDRICOS E SEUS ATRIBUTOS …....................... 13

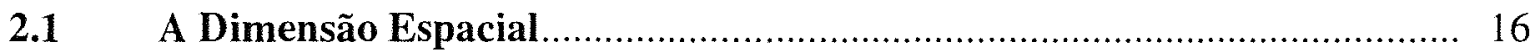

2.1.1 O ambiente natural a ser estudado ........................................................... 16

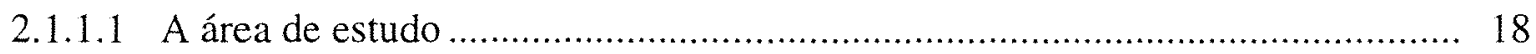

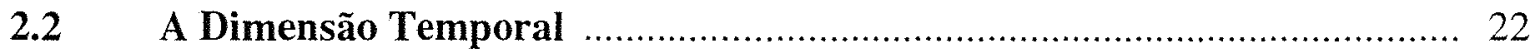

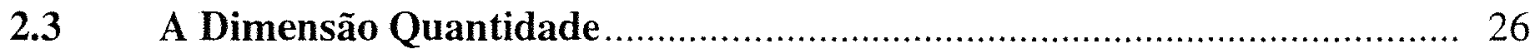

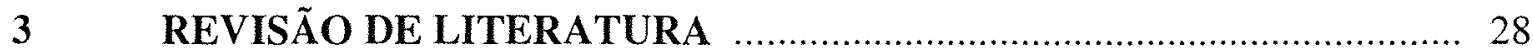

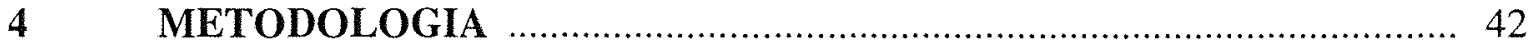

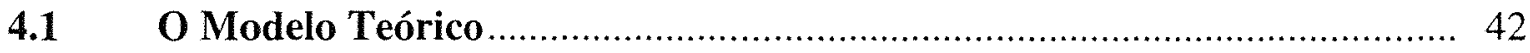

4.1.1 A contribuição da teoria microeconômica ao estudo .................................... 42

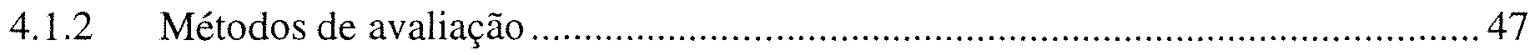

4.1.2.1 Método da programação linear................................................................... 47

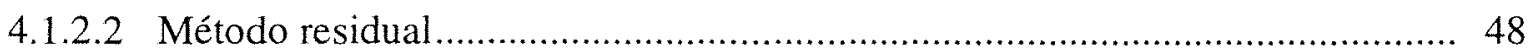




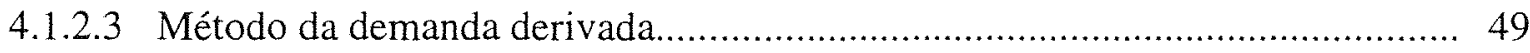

4.1.2.4 Método da função de produção .................................................................. 51

4.1.3. A função de produção............................................................................... 52

4.1.4 A utilização da função de produção .............................................................. 56

4.1.4.1 A. eficiência técnica e econômica no uso dos fatores .................................... 56

4.1.4.2 A demanda por um fator variável ............................................................. 59

4.1.4.3 Procedimento analítico com as funções de demanda .................................... 60

4.1.5. Disposição a pagar por um fator de produção …………………….................... 62

4.1.6 Elasticidade de demanda derivada ..........................................................6 65

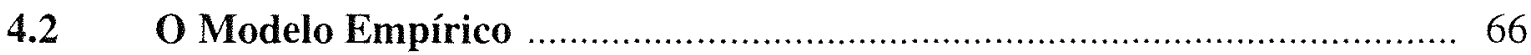

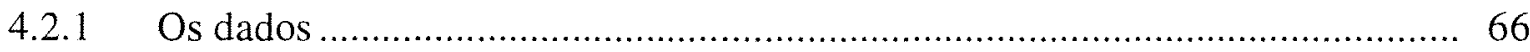

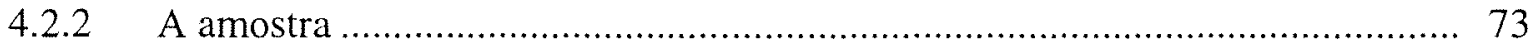

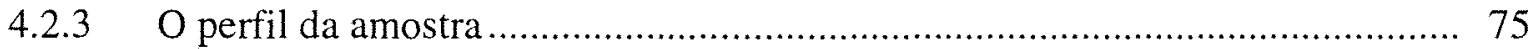

4.2.4 Definição dos elementos de análise ............................................................. 79

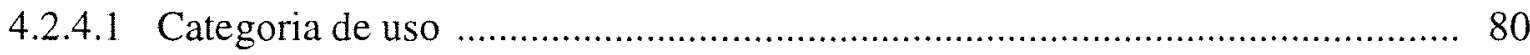

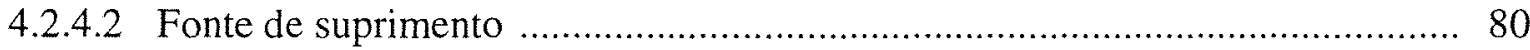

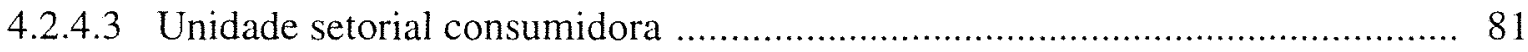

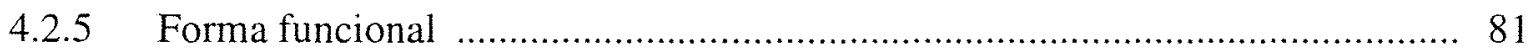

4.2.5.1 Ajustamento das funções (Modelo Ulveling-Fletcher) …........................... 92

4.3 Descrição das Variáveis Independentes …........................................... 93

4.4 Considerações Sobre as Variáveis Utilizadas nos Modelos

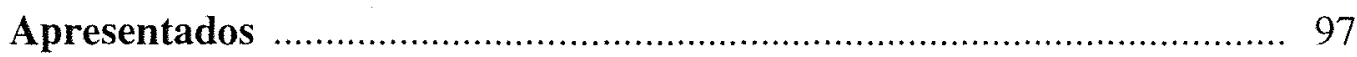

$5 \quad$ ANÁLISE E DISCUSS ÃO

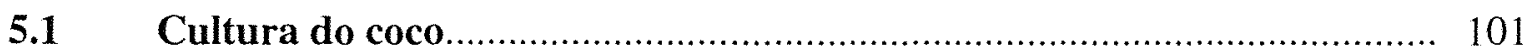

5.1.1 A demanda dágua para coco ............................................................ 108

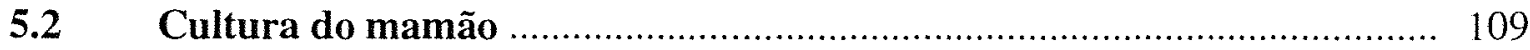

5.2.1 A demanda dágua para mamão ........................................................... 118

5.3 Cultura da cana-de-açúcar (Etapa I) ................................................... 119 
5.3.1 A demanda dágua para cana-de-açúcar (etapa I) .................................... 125

5.4 Cultura da cana-de-açúcar (Etapa II) ................................................. 126

5.4.1 A demanda dágua para cana-de-açúcar (etapa II) ...................................... 131

5.5 A Oferta Dágua para as Culturas em Estudo .......................................... 132

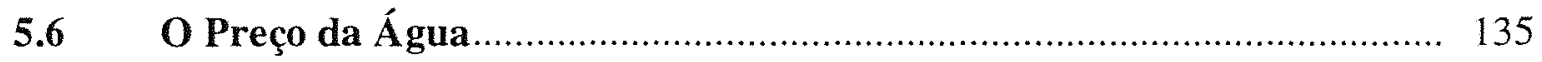

5.7 Disposição à Pagar por Água ….................................................... 140

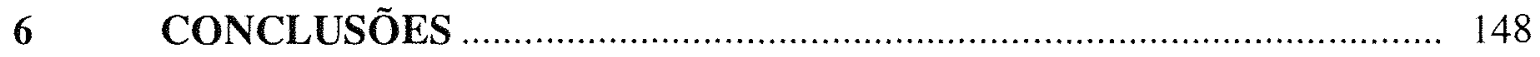

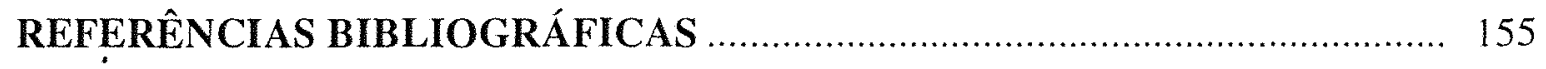

Apêndice 1: DADOS BÁSICOS UTILIZADOS PARA A ESTIMATIVAS

DAS FUNÇÕES DE PRODUÇÃO ....................................................... 162

Apêndice 2: MODELOS TESTADOS NAS ESTIMATIVAS DAS

FUNCÕES DE PRODUÇÃO ..................................................................... 167

Apêndice 3: TESTES E ANÁLISES ESTATÍSTICAS UTILIZADOS ........................... 172

Apêndice 4: METODOLOGIAS DE CÁlCULO DO PRODUTO MÉDIO,

DO VALOR DO PRODUTO MARGINAL E

INFORMAÇÕES SOBRE OS PREÇOS DOS FATORES E

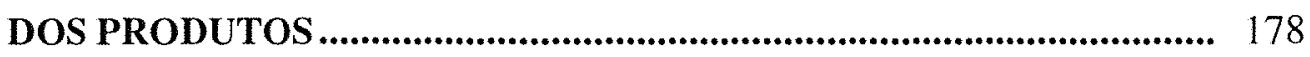

Apêndice 5: CÁLCULO DO PREÇO DA ÁGUA .................................................. 181

Apêndice 6: CÁlCULO DAS ELASTICIDADES PREÇOS DA ÁGUA ..................... 184

Apêndice 7: CÁlCULO DA dISPOSIÇÃo A PAGAR (DAP) POR ÁGUA ................. 186 
Apêndice 8: PORTARIA $\mathrm{N}^{\circ}$ 18, DE 13 DE FEVEREIRO DE 1995, DO MINISTÉRIO DO MEIO AMBIENTE, DISPONDO SOBRE FIXAÇÃO DE TARIFAS DE ÁGUA 188

Apêndice 9: MODELO DO QUESTIONÁRIO APLICADO NO PROJETO CURU-PARAIPABA 191 


\section{LISTA DE FIGURAS}

Página

1 Localização geográfica da Bacia do Curu no Estado do Ceará..

2 O projeto Curu-Paraipaba no contexto da Bacia do Curu

3 O impacto econômico resultante do deslocamento da demanda dágua

4 O impacto econômico resultante do deslocamento da oferta dágua 25

5 Representação gráfica do modelo benefício-custo

6a Água disponível no reservatório, oferta e demanda das culturas relevantes 45

6b Oferta e demanda de curto prazo de água das culturas relevantes 45

7 Alocação ótima de água entre dois produtores 60

8 Alocação ótima versus alocação feita pelo governo 61

9 Ajustamento do mercado decorrente de ineficiências 62

10. Valor do produto marginal de um serviço produtivo 64 


\section{LISTA DE TABELAS}

Página

1 Resenha de algumas pesquisas sobre o preço da água, feitas nos EUA, destacando as culturas, métodos e autores. Período 1973-1984

2 Área cultivada por etapa segundo as formas de exploração no projeto Curu-Paraipaba, safra 1994/95

3 Área cultivada das linhas de exploração e importância relativa por etapa do projeto Curu-Paraipaba, safra 1994/95.

4 Valor bruto da produção das linhas de exploração e importância relativa por etapa do projeto Curu-Paraipaba, safra 1994/95

5 Número de produtores, área cultivada, produção e valor da produção por estrato de área da cana-de-açúcar, etapa I do projeto CuruParaipaba, safra 1994/95

6 Número de produtores, área cultivada, produção e valor da produção por estrato de área da cana-de-açúcar, etapa II do projeto CuruParaipaba, safra 1994/95

7 Número de produtores, área cultivada, produção e valor da produção por estrato de área do mamão, etapa I do projeto Curu-Paraipaba, safra 1994/95 
8 Número de produtores, área cultivada, produção e valor da produção por estrato de área de coco, etapa I do projeto Curu-Paraipaba, safra $1994 / 95$

9 Parâmetros utilizados para o cálculo do tamanho da amostra para as culturas de cana-de-açúcar, coco e mamão na etapa I e cana-de-açúcar na etapa II

10 Valor do produto médio (VPMe $\mathrm{xi}_{\mathrm{i}}$ ) (exceto água), valor do produto marginal $\left(V P M g_{x i}\right)$, preços dos fatores $\left(\mathrm{Px}_{\mathrm{i}}\right)$ e relação entre os valores dos produtos marginais e os preços fatores $\left(\mathrm{VPMg}_{\mathrm{xi}} / \mathrm{Px}_{\mathrm{i}}\right)$, incluídos na função de produção de coco, projeto Curu-Paraipaba, Estado do Ceará. Ano agrícola 1995/96

11 Taxa marginal de substituição entre os fatores (exceto água) incluídos na função de produção de coco do projeto Curu-Paraipaba, Estado do Ceará, ano agrícola 1995/96 107

12 Relação entre os preços dos principais fatores (exceto água) utilizados no projeto de irrigação Curu-Paraipaba, Estado do Ceará, ano agrícola 1995/96. 108

13 Valor do produto médio (VPMe $\mathrm{xi}_{\mathrm{i}}$ ) (exceto água), valor do produto marginal $\left(\mathrm{VPMg}_{\mathrm{x} i}\right)$, preços dos fatores $\left(\mathrm{Px}_{\mathrm{i}}\right)$ e relação entre os valores dos produtos marginais e os preços fatores $\left(\mathrm{VPMg}_{\mathrm{xi}} / \mathrm{Px}_{\mathrm{i}}\right)$, incluídos na função de produção de mamão, projeto Curu-Paraipaba, Estado do Ceará. Ano agrícola 1995/96. 
14 Taxa marginal de substituição entre os fatores (exceto água) incluídos na função de produção de mamão do projeto Curu-Paraipaba, Estado do Ceará, ano agrícola 1995/96

15 Valor do produto médio (VPMe $\mathrm{x}_{\mathrm{xi}}$ ) (exceto água), valor do produto marginal $\left(\mathrm{VPMg}_{\mathrm{xi}}\right)$, preços dos fatores $\left(\mathrm{Px}_{\mathrm{i}}\right)$ e relação entre os valores dos produtos marginais e os preços fatores $\left(\mathrm{VPMg}_{\mathrm{xi}} / \mathrm{Px}_{\mathrm{i}}\right)$, incluídos na função de produção de cana-de-açúcar (etapa I), projeto CuruParaipaba, Estado do Ceará. Ano agrícola 1995/96.

16 Taxa marginal de substituição entre os fatores (exceto água) incluídos na função de produção de cana-de-açúcar (etapa I) do projeto CuruParaipaba, Estado do Ceará, ano agrícola 1995/96.

17 Valor do produto médio (VPMe $\mathrm{xi}_{\mathrm{i}}$ ) (exceto água), valor do produto marginal ( $\left.\mathrm{VPMg} \mathrm{g}_{\mathrm{xi}}\right)$, preços dos fatores $\left(\mathrm{Px}_{\mathrm{i}}\right)$ e relação entre os valores dos produtos marginais e os preços fatores $\left(\mathrm{VPMg}_{\mathrm{xi}} / \mathrm{Px}_{\mathrm{i}}\right)$, incluídos na função de produção de cana-de-açúcar (etapa II), projeto CuruParaipaba, Estado do Ceará. Ano agrícola 1995/96.

18 Taxa marginal de substituição entre os fatores (exceto água) incluídos na função de produção de cana-de-açúcar (etapa II) do projeto CuruParaipaba, Estado do Ceará, ano agrícola 1995-96 130

19 Quantidades de água fornecida e despesas com energia elétrica por etapa, no perímetro Curu-Paraipaba, Estado do Ceará, ano agrícola de $1995 / 96$ 
20 Quantidades de água e despesas com energia elétrica previstas e efetivas nas culturas selecionadas para estudo, no projeto CuruParaipaba, Estado do Ceará, ano agrícola de 1995/96

21 Distribuição da água por cultura e etapa, segundo o critério de preço e pelo sistema prevalecente no projeto Curu-Paraipaba, ano agrícola $1995 / 96$.

22 VBP proposto e efetivo, despesas fixas, DAP* proposta e efetiva e gastos efetivos com energia elétrica por cultura, projeto CuruParaipaba, Estado do Ceará, ano agrícola 1995/96 (em mil reais)

23 DAP*, valor a pagar, excedente, e despesas com energia elétrica, relacionadas com a água, por cultura, no projeto Curu-Paraipaba, ano agrícola 1995/96 (em mil reais)

24 Produtividade da água expressa pelo valor bruto da produção (em mil reais) por mil $\mathrm{m}^{3}$ de água, no modelo de distribuição proposto e vigente, por cultura, no projeto Curu-Paraipaba, Estado do Ceará, ano agrícola de 1995/96.

25 DAP por água proposta e efetiva e custos totais de operação e manutenção de sistema de suprimento propostos e efetivos, por cultura, etapa I do projeto Curu-Paraipaba, Estado do Ceará, (em mil reais), a preços de dezembro de 1995

26. Dados utilizados na estimativa da função de produção de coco, projeto Curu-Paraipaba, Estado do Ceará, ano agrícola 1995/96 
27. Dados utilizados na estimativa da função de produção de mamão, projeto Curu-Paraipaba, Estado do Ceará, ano agrícola 1995/96 164

28. Dados utilizados na estimativa da função de produção de cana-deaçúcar, etapa I, projeto Curu-Paraipaba, Estado do Ceará, ano agrícola 1995/96

29. Dados utilizados na estimativa da função de produção de cana-deaçúcar, etapa II, projeto Curu-Paraipaba, Estado do Ceará, ano agrícola $1995 / 96$

30. Modelos testados em estimativas da função de produção de coco no projeto Curu-Paraipaba, Estado do Ceará, ano agrícola-1995/96 168

31. Modelos testados em estimativas da função de produção de mamão no projeto Curu-Paraipaba, Estado do Ceará, ano agrícola-1995/96

32. Modelos testados em estimativas da função de produção de cana-deaçúcar, etapa I, no projeto Curu-Paraipaba, Estado do Ceará, ano agrícola-1995/96 170

33. Modelos testados em estimativas da função de produção de cana-deaçúcar, etapa II, no projeto Curu-Paraipaba, Estado do Ceará, ano agrícola-1995/96

34. Teste de Glejser para heterocedasticidade 173

35. Diagnóstico de colinearidade 
36 .Coeficientes de correlação simples entre as variáveis independentes utilizadas nas estimativa de função de produção de coco, projeto Curú-Paraipaba, Estado do Ceará, ano agrícola 1995/96

37 .Coeficientes de correlação simples entre as variáveis independentes utilizadas nas estimativa de função de produção de mamão, projeto Curú-Paraipaba, Estado do Ceará, ano agrícola 1995/96

38 . Coeficientes de correlação simples entre as variáveis independentes utilizadas nas estimativa de função de produção de cana-de-açúcar, etapa I, projeto Curú-Paraipaba, Estado do Ceará, ano agrícola $1995 / 96$

39 .Coeficientes de correlação simples entre as variáveis independentes utilizadas nas estimativa de função de produção de cana-de-açúcar, etapa II, projeto Curú-Paraipaba, Estado do Ceará, ano agrícola $1995 / 96$

40. Preço máximo, mínimo, anual e, médio mensal do coco, mamão e cana-de-açucar, recebidos pelos produtores do projeto CuruParaipaba no período de julho de 1994 a março de 1998 


\title{
VALOR ECONÔMICO DA ÁGUA PARA IRRIGAÇÃO NO SEMI-ÁRIDO CEARENSE
}

\author{
Autor: JOSÉ CESAR VIEIRA PINHEIRO \\ Orientador: Prof. Dr. RICARDO SHIROTA
}

\section{RESUMO}

Este trabalho é o resultado de um esforço de avaliação do critério atual de distribuição e fixação da tarifa dágua destinada à irrigação. Procurou-se fazer a valoração da água através das suas curvas de demanda de curto prazo. Estas curvas foram obtidas a partir das funções de produção de culturas selecionadas. A parte empírica foi desenvolvida no projeto Curu-Paraipaba no Estado do Ceará utilizando-se informações referentes ao ano agrícola de 1995/96. O trabalho analisa também o efeito indireto de algumas características sócioeconômicas do produtor, tais como, nível de educação, idade, e grau tecnológico do irrigante, sobre a produção.

No cenário atual, o governo faz a distribuição da água com base no consumo médio por hectare e a tarifa é definida com vistas à recuperação dos custos operacionais de suprimento. Não existe exclusividade de uso para a água. A rentabilidade das culturas e a disposição do produtor a pagar pela água não são consideradas no critério alocativo.

Os resultados das simulações revelaram que os preços dos produtos afetam diretamente o valor da água. Assim, sendo a água escassa no semi-árido, uma forma de valorizá-la seria irrigar culturas de alto valor.

O estudo mostrou que, na situação prevalecente, o preço eficiente da água seria de $\mathrm{R} \$ 140,61 / \mathrm{mil} \mathrm{m}^{3}$. A cultura do coco deveria ser fortemente estimulada, 
mediante a redistribuição da água que vinha sendo utilizada na cana-de-açúcar e no mamão. O confronto do uso atual da água com a distribuição sugerida pelo modelo mostra que $36,6 \%$ da água não estava sendo alocada em culturas de maior valor (coco). Este é um indicador do tamanho do desperdício.

Se cada cultura recebesse a quantidade ótima de água, o VBP cresceria substancialmente. A receita gerada pelo pagamento da água cobriria com folga os custos de operação e manutenção do sistema de suprimento. A pesquisa ganha importância particular por ter sido feita no semi-árido cearense, onde a água é escassa e a agricultura depende da irrigação para produzir durante a estação seca.

Isto confirma os resultados de vários estudos de avaliação econômica de projetos de irrigação no Nordeste. Muitos deles apresentaram rentabilidade modesta e não puderam remunerar adequadamente os fatores de produção empregados. 


\title{
ECONOMIC VALUE OF WATER FOR IRRIGATION IN THE SEMI-ARID REGION OF CEARÁ
}

\author{
Author: JOSÉ CESAR VIEIRA PINHEIRO \\ Adviser: Prof. Dr. RICARDO SHIROTA
}

\section{SUMMARY}

This study is the result of an attempt to evaluate the current irrigation water distribution and price setting criteria in a irrigation project located in the semi-arid region in the State of Ceará, Brazil. The value of water was calculated using estimated short-run demand curves. These curves were obtained from empirically determined production functions for selected crops. The empirical part of the study was conducted in

the 'Curu-Paraipaba' Irrigation Project using data collected for the 1995/96 crop season. This work also estimates the indirect effect of a few social-economic characteristics of the farmers, such as education, age and the level of technology on the production.

In the scheme prevailing, a public company distributes the water according to a given, per hectare, average consumption and the rate is determined to a level that recovers the operational costs. There is no exclusivity in the water use. The returns of the different crops as well as the farmers' willingness to pay are not considered in the allocative criteria.

The results from a simulation show that crops prices directly affect the water value. Thus, considering that the water is scarce in the semi-arid region, an alternative to increase its value could be obtained through the irrigation of high price crops.

The study shows that the efficient rate for water in the project would be $\mathrm{R} \$$ 140.61 / thousand cubic meter. The coconut would be strongly stimulated through the redistribution of water from sugar-cane and papaya. The comparison of the actual water use with the distribution suggested by the model indicates that $36.6 \%$ of the water is 
being allocated in the wrong crop. This is an indication of the current level of inefficiency.

If each crop received the optimal quantity of water, the gross production value would increase significantly. The receipt generated by the payment for the water would be more than enough to cover the cost of operation and maintenance. This study is particularly relevant in the semi-arid region of the State of Ceara, where the water is scarce and the agriculture depends on the irrigation in the periods.

This confirms the results obtained in several studies of economic evaluation of irrigation projects in the northeast region of Brazil. Many of them show modest returns and did not adequately remunerate the factors of production used. 


\section{INTRODUÇÃO}

A ocorrência periódica de secas ${ }^{\prime}$ tem sido citada pelos estudiosos do semi-árido nordestino como uma das principais causas da crescente urbanização, resultante de um fluxo migratório intenso e contínuo na direção das cidades e de estados do Centro-Sul do País (Sampaio, 1987). Neste contexto, o Ceará apresenta as características edafoclimáticas comuns no semi-árido nordestino, que são a baixa precipitação média anual, de cerca de $750 \mathrm{~mm}$, e grandes variações pluviométricas intra e interanuais (Figueroa, 1977). O autor acrescenta, ainda, que os solos da região são cristalinos, impermeáveis, rasos e pedregosos, com relevo variando de suave a acentuado.

Estudos da Secretaria de Recursos Hídricos (SRH, 1994) permitem fazer uma estimativa da repetição de ocorrência de secas no Estado entre 10 e 15\%. A análise dos índices mensais de pluviometria e deficits médios, em 33 postos pluviométricos com representatividade espacial em todo o Estado ${ }^{2}$, mostraram que os períodos com maior deficiência hídrica, em ordem decrescente, foram: 1978/83, 1951/54, 1940/44, 1957/60, 1931/33, 1936/37, 1969/71 e 1918/19 (Herbst 1986). Secas extremas em grau de severidade ocorreram, respectivamente, em 1983, 1953, 1942, 1958, 1932, 1970 e 1919. Um estudo mais recente, cobrindo o período 1960-90 acrescenta os anos de 1987 e 1990, classificados como de secas severas (DNOCS, 1993).

\footnotetext{
${ }^{1}$ O conceito de seca não é de fácil e imediato consenso. Uma seca climatológica (pequenas quantidades e má distribuição das precipitaçōes) pode ou não significar uma seca agrícola (insucesso da agricultura de sequeiro). Isto vai depender da capacidade de convivência da população atingida e, quanto mais carente e despreparada ela for, maior será seu grau de severidade.

${ }^{2}$ As séries em 16 postos foram de muito longa duração (1913/88), e, em 13 postos, de longa duração $(1935 / 88)$.
} 
A distribuição interanual de chuvas apresenta um coeficiente de variação (CV) entre $40 \%$ e $50 \%$. Segundo a Secretaria de Recursos Hídricos (SRH, 1991), em algumas regiões do Estado, o CV pode ultrapassar a taxa de 55\%. A área de maior abrangência no Estado recebe uma média anual de chuvas de $750 \mathrm{~mm}$. A região dos Inhamuns tem a menor média de precipitação anual, em torno de $400 \mathrm{~mm}$. No outro extremo, em alguns locais da região da Ibiapaba, a média pode alcançar os $2.000 \mathrm{~mm}$.

No semi-árido cearense, há grande concentração de precipitações pluviométricas no primeiro semestre do ano, chegando a representar $90 \%$ da chuva anual. Dois terços dessas chuvas ocorrem num só trimestre, que pode ser março/maio (na região Leste do Estado) e em fevereiro/abril (na região Oeste). No mês de março, chove, em média, $25 \%$ da precipitação anual. Nestas épocas ocorrem, com freqüência, precipitações intensas em curto intervalo de tempo intercalados com períodos de total ausência de chuvas. Conforme Nimer (1979), o regime anual de chuvas na região semiárida do Nordeste tem como característica mais marcante sua forte concentração estacional, em 2, 3 ou 4 meses. Isto evidencia o fato de que, nos anos de redução drástica de chuvas não haverá compensação hídrica em outras épocas do ano. O autor diz enfaticamente que uma outra peculiaridade importante do semi-árido é a brusca passagem da estação seca para a chuvosa e vice-versa.

A insolação no semi-árido é muito alta. O número médio de horas de sol tem amplitude que varia de 2.650 horas/ano, até quase 3.000 horas/ano. Como conseqüência, a evaporação é responsável por grandes perdas hídricas, sobretudo no segundo semestre do ano, agravando os períodos de secas. Os níveis médios de evaporação encontrados em tanque Classe A situam-se em $2.300 \mathrm{~mm}$ no litoral e $2.800 \mathrm{~mm}$ no sertão.

A peculiaridade do Ceará no contexto do semi-árido nordestino está no aspecto geológico. As consequiências em termos de disponibilidades hídricas, citadas anteriormente, são ainda mais agravadas pela predominância de rochas cristalinas que abrangem 70\% do território estadual (SRH, 1991). Essa publicação menciona que "o aproveitamento deste tipo de solos como aqǘfero comporta restrições sérias quanto a 
vazão e a qualidade da água, freqüentemente salinizada". O baixo poder de retenção de água dos solos cristalinos impede a formação de reservas significativas de água nos períodos secos.

Dentro destes condicionantes climáticos e geológicos, os rios de praticamente todo o semi-árido cearense são periódicos, parando de escoar, em média, um mês após cessarem as chuvas (Gondim Filho, 1988). Quando ocorre uma seca no ano seguinte, não há reposição dágua e os rios podem passar secos 20 ou mais meses.

\subsection{A Política de Combate às Secas}

O quadro edafo-climático prevalecente no semi-árido imprime grande fragilidade à economia agrícola nordestina e, em particular, ao Ceará. O produto e emprego oscilam de ano para ano, como consequiência da irregularidade das precipitações. A análise do efeito das secas entre 1979 e 1983 sobre a produção agrícola cearense mostra uma redução de $83 \%$ em 1983 em relação ao ano de 1978, que teve precipitações normais. As perdas totais do período chegaram a 1,6 milhões de toneladas de algodão, 4 milhões de toneladas de mandioca e 3 milhões de toneladas de milho (Campos \& Khan, 1989). Uma das conclusões do estudo é que foram desempregados no meio rural 850.000 nordestinos em 1983. Segundo a Superintendência de Desenvolvimento do Nordeste (SUDENE, 1984), "Com as frustrações de safra e redução da renda decorrente do período de seca 1978-83, a única saída para sobrevivência da população afetada foi a migração para os centros urbanos à procura de emprego. O saldo migratório (imigração menos emigração) dos estados do Nordeste, em 1980, foi de cerca de $-5,5$ milhões de pessoas".

O caráter intermitente dos rios incentivou a construção de reservatórios de pequenos, médios e grandes tamanhos, para regularização do suprimento de água no verão, tanto pelo poder público quanto pela iniciativa privada. Os açudes de tamanho 
pequeno e médio ${ }^{3}$ desempenham importante papel mas não conseguem atender às necessidades de suprimento em longas estiagens. Mota (1995) afirma que os grandes açudes são dimensionados para fornecer água mesmo em secas severas com períodos de 2 ou 3 anos seguidos de duração.

Esse é o caso do açude do Cedro, no Ceará, inaugurado em $1906^{4}$, com $50 \mathrm{~km}$ de canais de irrigação. Deste então, até o ano de 1992, o Departamento Nacional de Obras Contra as Secas (DNOCS) já construiu, no Estado, 76 açudes de grande porte, com capacidade total de acumulação da ordem de 7,93 bilhões de $\mathrm{m}^{3}$ dágua (Mota, 1995). Segundo este autor, os custos de projeto, construção e desapropriação de 40 destes grandes reservatórios foram de US\$ 194 milhões, a preços de fevereiro/93, evidenciando o alto investimento feito no setor de recursos hídricos no Ceará.

Até a década de 60, os esforços do DNOCS na Região se limitavam à execução de obras de engenharia para formação de infra-estrutura. Questões institucionais importantes como a estrutura fundiária limitavam qualquer projeto de irrigação em larga escala. Em 1940, a área irrigada em todo o Nordeste não ultrapassava 500 ha, o que é muito reduzido, considerando que o IFOCS havia sido criado há 34 anos (França \& Pereira, 1990).

Mas a necessidade dágua em pontos dispersos da Região era imperiosa para atender às necessidades humanas e animais. Isto levou o governo federal à construção de grandes açudes dentro de um sistema de cooperação entre o setor público e o grande proprietário rural.

A partir de 1963, as ações voltadas para o aproveitamento dos recursos hídricos foram racionalizadas através do I Plano Diretor da SUDENE. Este foi o início de uma política bem mais definida na área de irrigação, para melhor utilização de todo este

${ }^{3}$ O DNOCS classifica como açude pequeno aquele que pode armazenar um volume de até 1 milhão de $\mathrm{m}^{3}$ dágua e açude médio até 10 milhões de $\mathrm{m}^{3}$.

${ }^{4}$ Ano de criação do IFOCS (Inspectoria Federal de Obras Contra as Secas). O DNOCS ( Departamento Nacional de Obras Contra as Secas) foi instituído em 1945, sendo sucedâneo do IFOCS. 
potencial de armazenamento dágua. Esta política foi viabilizada pelo Estatuto da Terra, que, em um de seus dispositivos, permitiu a intervenção fundiária, inclusive desapropriações, por interesse social. Isto fez com que, no período entre 1970 e 1992, o DNOCS desapropriasse 207,7 mil ha, com área total indenizada de 138 mil ha (DNOCS, 1993).

Reconhecendo a necessidade da irrigação para o progresso da agricultura regional, o Governo Federal criou, via decreto 92.344, de 29.01.86, o Programa de Irrigação do Nordeste (PROINE). Em 1992, o DNOCS já contava com uma área irrigada de 18.697 ha no Ceará, beneficiando direta e indiretamente 44,3 mil pessoas, através de seus projetos de irrigação pública (DNOCS, 1993).

A partir do início da década de 90, a tradicional política de combate às secas via formação de infra-estrutura e historicamente voltada para o setor de engenharia, passou por significativa reorientação. Primeiro porque a constituição de 1988 permitiu a descentralização administrativa, e segundo, em virtude das reformas institucionais promovidas no governo Collor, acarretando esvaziamento do DNOCS, inclusive com ameaças de sua extinção. Ainda, neste mesmo período, terminava a vigência dos contratos de financiamentos internacionais, com poucas perspectivas de renovação.

Nessa época, havia uma multiplicidade de planos, programas e projetos de irrigação, sem que houvesse uma compatibilização entre o programado e executado, e quase total ausência de avaliação dos resultados até então alcançados.

O PROINE contratou diversas pesquisas sobre os aspectos agroeconômicos e a capacidade de pagamento do pequeno irrigante no Nordeste. A maioria dos estudos, mostravam que os irrigantes encontravam-se num patamar de renda muito longe do desejável. Mesmo assim, muitos investimentos tinham sido feitos em irrigação no Nordeste. A orientação política passou a ser voltada para o gerenciamento de toda a infra-estrutura, com forte interveniência dos governos estaduais e gestão participativa dos irrigantes. A prioridade era agilizar o processo de emancipação dos projetos públicos 
de irrigação, sem o qual haveria a necessidade de manter um esquema permanente de subsidios.

O ajuste institucional do governo no Estado do Ceará à nova orientação política deu-se através do Sistema Integrado de Gestão dos Recursos Hídricos (SIGERH), criado pela Lei 11.996 de 24.07.92. Em 1993, o Estado criou a Companhia de Gerenciamento dos Recursos Hídricos (COGERH).

Todo este aparato institucional pretendia congregar as instituições estaduais, federais e municipais intervenientes no planejamento, administração e regulamentação dos recursos hídricos (sistema de gestão); os responsáveis pelas obras e serviços de oferta, utilização e preservação dos recursos hídricos (sistemas afins); serviços de planejamento e coordenação geral, incentivos econômicos e fiscais, ciências e tecnologia, defesa civil e meio ambiente (serviços correlatos); e colegiados representativos dos usuários de água e da sociedade civil.

Como parte da estrutura do SIGERH, foi instituído um órgão colegiado, o Conselho de Recursos Hídricos do Ceará (CONERH), de caráter deliberativo. A Lei No 11.996 considerava no seu Art.2 que, “ um dos princípios fundamentais que a Política Estadual de Recursos Hídricos atenderá é o de que a água, como recurso limitado que desempenha importante papel no processo de desenvolvimento econômico e social, impõe custos crescentes para sua obtenção, tornando-se um bem econômico de expressivo valor". O Art. 3 parágrafo único da mesma Lei afirmava que: "Os recursos hídricos utilizados serão cobrados segundo peculiaridades de cada Bacia Hidrográfica, na forma como vier a ser estabelecido pelo CONERH e o produto encaminhado ao Fundo Estadual de Recursos Hídricos (FUNERH). 
Embora o dispositivo do Art. 3 seja flexível, inicialmente, foi estabelecida a cobrança com base em portaria ministerial ${ }^{5}$, que definia tarifas diferenciadas para a água, dependendo do local e dos distintos usos (apêndice 8).

Mas como a portaria só podia ser cumprida com a existência de medidores, e como a água não é medida em grande parte dos projetos de irrigação pública federal no Ceará, sua aplicação tornou-se inviável. Além disso, as tarifas não cobriam os custos de suprimento da água. Isto significava pesados subsídios e com as restrições orçamentarias em decorrência das razões já mencionadas, o governo passou a estimular uma política de emancipação dos perímetros irrigados. Em articulação com o DNOCS, o Estado estabeleceu um modelo tarifário de cobrança pelo uso da água baseado no princípio de cost recovery. Ressalte-se, tudo isto ocorreu em plena vigência da portaria ministerial.

Young (1985) alerta que os EUA adotaram tal princípio nas 3 (três) primeiras décadas deste século, com insucesso. A partir de 1939, os EUA passaram a utilizar o principio da capacidade de pagamento que preconiza a recuperação plena apenas dos custos operacionais, mais uma pequena fração do investimento inicial. Este autor considera "um conceito subjetivo e sujeito a pressão política por parte dos usuários". Se a tarifa cost-recovery for maior do que aquela que o usuário estaria disposto a pagar (DAP), torna-se evidente a necessidade de subsídios. Caso contrário, o governo fica em condições de fixar uma tarifa capaz de cobrir todos os custos, além da possibilidade de prover melhorias e expansão do sistema no longo prazo.

Neste modelo, a tarifa deve ser fixada de maneira tal que, considerando um certo horizonte temporal, sejam recuperados os investimentos realizados e cobertos os custos operacionais. O item pago pelos irrigantes é energia elétrica. Mensalmente, o DNOCS faz um rateio entre os usuários da água, da fatura de energia, independente dos gastos de água de cada um.

\footnotetext{
${ }^{5}$ Portaria No 18, de 13 de fevereiro de 1995, do Ministério do Meio Ambiente, dos Recursos Hídricos e da Amazônia Legal que autorizou o DNOCS a cobrar os valores fixados nos perímetros irrigados, com vigência até 31 de dezembro de 1995.
} 
O problema é que, embora as despesas sejam equitativas, cada produtor capta uma quantidade diferente de água. Segundo Randall (1987), este é um problema típico de falha de mercado. $O$ autor conceitua especificamente este fato como uma atenuação do direito de propriedade. A água passa a ser um bem não-exclusivo e um eventual "mercado de água" passa a ser distorcido e emitir permanentemente sinais errados. Neste caso, o preço não racionaliza o uso da água. Não é garantido ao produtor mais eficiente, e que esteja disposto a pagar mais, o direito de ter água na quantidade e no tempo desejados.

Sendo um critério de natureza política refletindo profundas raízes culturais do Nordeste, sentimentos como - "a água não deve ser submetida as severas leis do mercado"-, então, normas no domínio res communis são estabelecidas. São regras de acesso à água que emergem dos próprios irrigantes, com interesses comuns, tais como, escalonamento de datas de suprimentos, horários alternados, equipamentos homogêneos, dentre outros. Mas, sendo regras "não oficiais", não existem sanções ou penalidades, com necessário suporte jurídico, para quem não obedecê-las, sendo uma permanente fonte de conflitos.

Este modelo de cobrança e distribuição não incentiva o uso econômico de água ${ }^{6}$. O irrigante não procura utilizar água de forma parcimoniosa. O estímulo ao super uso, talvez, possa explicar culturas de baixa rentabilidade ocupando grandes áreas nos lotes. Os produtores mais próximos das fontes são extremamente beneficiados. Aqueles situados na porção final do sistema de distribuição são ainda mais prejudicados pela manutenção deficiente dos canais.

Existe também uma tendência para sub-investimentos em manutenção. Um relatório da primeira reunião anual da COGERH (1995) aponta a falta de adequada manutenção num canal com $31,3 \mathrm{~km}$, que serve ao projeto Curu-Recuperação, no

\footnotetext{
${ }^{6}$ O irrigante não tem incentivo para adotar uma tecnologia, por exemplo, irrigação por gotejamento, se vai pagar no final do mês, uma conta de energia elétrica idêntica ao seu vizinho perdulário. Além disso, teria que investir em novos equipamentos, num projeto que não dispõe de crédito.
} 
Município de Pentecoste-CE, que reduziu a capacidade de vazão do canal de $0,94 \mathrm{~m}^{3} / \mathrm{s}$, para $0,42 \mathrm{~m}^{3} / \mathrm{s}$. Outro estudo no mesmo projeto mostrou que os lotes situados na porção final dos canais de irrigação ficam prejudicados em virtude da escassez dágua decorrente de inúmeros vazamentos existentes em toda a sua extensão (DNOCS, 1993).

O modelo vigente também incentiva gastos em equipamentos com maior poder de captação, dentro do ambiente de escassez. Embora estes devam ser padronizados, muitos artifícios são utilizados, como por exemplo, aumento no diâmetro das tubulações, da vazão dos aspersores ${ }^{7}$ e capacidade de armazenamento. Nestas condições, tecnologias poupadoras de água (como seria o caso de irrigação por gotejamento) são desistimuladas. Isto poderia explicar o reduzido percentual de adoção destas técnicas nos projetos de irrigação pública no Ceará.

A questão distributiva da água entre culturas, lotes, setores e projetos não tem sido devidamente focalizada. Na política de gestão dos recursos hídricos, o interesse maior está no consumo global para estabelecer o balanço hídrico de toda a Bacia. A decisão sobre a quantidade de água a ser suprida no ano agrícola para um dado projeto de irrigação pouco considera a rentabilidade econômica das culturas. Os critérios são mais respaldados em projeções da área cultivada e do consumo médio. A SRH (1991) orienta os executores da irrigação pública a utilizar uma quantidade média que pode atingir o limite de até $18.000 \mathrm{~m}^{3}$ de água por ha/ano. A quantidade total dágua a ser ministrada é calculada, às vezes, pela simples multiplicação deste número ${ }^{8}$ pela área total de plantio. Quando os reservatórios não conseguem acumular água suficiente em virtude das baixas precipitações, a média de distribuição cai em função da quantidade total disponível.

\footnotetext{
${ }^{7}$ Aspersores com bicos de plástico podem ser manipuláveis para aumentar a vazão.

${ }^{8}$ Quando as disponibilidades dágua armazenada nos açudes permitem.
} 


\subsection{A Importância do Estudo}

As políticas de gerenciamento do uso da água atualmente adotadas dão prioridade aos custos de suprimento e ao consumo global no projeto. Quase toda orientação é voltada para o lado da oferta; não contemplam um modelo de demanda, que reflita a DAP, na formulação de uma política de preço e de distribuição da água internamente no projeto de irrigação.

Isto atenderia às necessidades de estudos sobre o uso racional da água, num Estado onde este é um dos principais fatores limitantes ao seu desenvolvimento.

Sendo a água escassa no semi-árido e com alto custo de obtenção, o seu uso na irrigação deveria objetivar o melhor retorno possível. Se o critério de alocação com base no consumo médio fosse substituído por um modelo de demanda confrontado com as disponibilidades, haveriam várias vantagens. A primeira seria a possibilidade de se estimar a DAP pelos irrigantes e o preço que deveria ser cobrado. Estas informações forneceriam elementos para estimar o valor da água para as culturas mais importantes, para os setores e projeto como um todo, e a quantidade a ser distribuída entre culturas e setores. A segunda seria permitir uma análise comparativa entre preços e quantidades definidas pelo modelo proposto, com preços e quantidades estabelecidos segundo o critério de cost recovery. Isto evidenciaria os ganhos potenciais e executar direitos exclusivos para quem paga pela água.

Análises de produtividades dos demais fatores que não a água e de rendimentos de escala serão consideradas nesse estudo, embora, sendo um enfoque de curto prazo sobre uso da água, não permita determinar o uso ótimo dos demais fatores; isto por falta de conhecimento das relações fator-fator e fator-produto numa perspectiva em que todos os fatores sejam variáveis. Neste estudo, se examinará o comportamento da demanda de água, frente a uma dada combinação de fatores disponíveis. A identificação destas relações poderia melhor orientar a alocação do recurso dando maior eficiência e eficácia aos instrumentos da política de irrigação. 
O grau de educação junto a outras características sócioeconômicas e à tecnologia adotada pelo produtor têm influência no uso da água. Pressupõe-se que produtores com melhor instrução utilizam tecnologias que contribuem para o aumento da produtividade da água e, eventualmente, dos demais fatores. Esta possível constatação torna-se importante para orientar ações destinadas a melhorar o grau de qualificação dos irrigantes.

Ademais, a determinação teórico-metodológica da disposição a pagar por água pode constituir-se numa contribuição em estudos sobre economia de recursos hídricos. Além disso, poder-se-ia testar a hipótese de que a água não é utilizada com eficiência, do ponto de vista econômico, em projetos de irrigação pública federal no Estado do Ceará.

\subsection{Objetivos}

Este trabalho pretende realizar uma análise econômica de um projeto de irrigação pública federal implantado no Ceará. Inicialmente, será estimada a curva de curto prazo da demanda para água; então, a identificação do ponto onde esta corta a oferta fixa permitirá a estimativa do preço de equilíbrio. O segundo passo será investigar de que modo está ocorrendo a alocação da água para as culturas mais relevantes e setores do projeto. Finalmente, pretende-se analisar o grau de eficiência no uso de recursos e o impacto de algumas características sócioeconômicas dos irrigantes, além da tecnologia, sobre a produção. Especificamente, pretende-se alcançar os seguintes objetivos:

a) Determinar o preço e quantidades ótimas de água a serem alocadas entre distintas culturas e setores de um perímetro irrigado e comparar estes parâmetros com os efetivamente estabelecidos, possibilitando medir os reflexos nos resultados econômicos de irrigantes e órgãos supridores de água; 
b) Analisar as implicações econômicas decorrentes da política tarifária de água exercitada pelo governo, através da comparação do preço praticado atualmente com o preço determinado pelo modelo proposto;

c) Medir o impacto de características sócioeconômicas e da tecnologia adotada pelo produtor sobre a produtividade dos recursos;

d) Identificar as produtividades marginais e taxas marginais de substituição referentes aos principais fatores, exclusive água, e as naturezas dos rendimentos de escala da produção, com vistas a examinar o grau de eficiência do uso dos recursos; e,

e) Apresentar uma proposta metodológica que permita a distribuição de água entre culturas e setores nos projetos de irrigação pública, com base em critérios econômicos. 


\section{OS RECURSOS HÍDRICOS E SEUS ATRIBUTOS}

Recursos naturais são multi-atributáveis e possuem quantidade, qualidade, tempo e dimensões espaciais (Randall, 1987). Quando se busca estabelecer o valor de um recurso natural, algumas ou a totalidade destas dimensões e seus atributos devem ser consideradas, dependendo da natureza do estudo (Giansanti, 1993).

A dimensão qualidade do recurso é multi-atribuída, seja por sua composição química, física, biológica e, inclusive, pelos aspectos estéticos. Todos estes atributos influem no valor do recurso. Eles podem ser percebidos diferentemente pelos diversos usos e usuários, tanto nos seus aspectos tangíveis como nos estéticos.

A avaliação da qualidade dos recursos hídricos, por exemplo, pode ser feita por parâmetros físicos que medem o odor, cor, condutividade elétrica e temperatura da água. Parâmetros químicos refletem o teor de substâncias dissolvidas, tais como sulfatos, metais pesados, agrotóxicos e outros. Os biológicos detectam a presença de organismos superiores, tais como peixes ou outras formas de vida no meio aquático, inclusive microorganismos.

A quantidade é unidimensional, podendo ser medida por uma unidade de massa ou volume, afetando o valor do recurso porque altera a sua reserva ou disponibilidade. A quantidade é valorizada pela reserva, capacidade de renovação e pela forma ou grau de dificuldade da extração.

A dimensão temporal é importante pela sua interação com a intensidade do fluxo e pela taxa de extração que reduz o estoque remanescente do recurso. A dimensão espacial está relacionada com a distância e a dificuldade de acesso. 
Cada uso da água requer um conjunto particular de atributos. Um curso dágua, com baixa energia potencial, teria alto valor para navegação e nenhum valor para a geração de energia elétrica.

Os atributos têm parâmetros próprios e, dado que a água tem múltiplos propósitos, forma-se um conjunto amplo de parâmetros que determinam a disponibilidade hídrica. Basta variar um parâmetro para alterar a disponibilidade hídrica para um determinado uso. Pode, inclusive, ocorrer que o estímulo a uma utilização específica inviabilize outras. A construção de uma hidrelétrica pode, por exemplo, resultar no desaparecimento de uma cachoeira de alto valor estético.

Considerando que a água pode apresentar distintos valores ao longo do tempo para os seus diferentes usos, torna-se fundamental definir claramente as dimensões e atributos que devem ser objeto de análise.

No presente estudo, serão consideradas apenas 3 (três) dimensões: quantidade, tempo e espacial. A dimensão qualidade é importante por envolver diversos problemas ligados à agricultura. A salinização, especialmente no Nordeste, seria um enfoque relevante. Mas, infelizmente, não existem informações detalhadas sobre o teor de sais na água, pelo menos, no Vale do Curu. Mesmo os dados quantitativos apresentam algumas limitações, já que os usuários individuais não dispõem de medidores. Obviamente a dimensão qualitativa é fundamental num estudo que envolva água destinada ao consumo humano.

Outra simplificação é que o estudo será restrito a apenas um uso, caso da irrigação, sem considerar os reflexos que poderiam ocorrer em usos opcionais. A irrigação é um uso consuntivo ${ }^{9}$, que implica o consumo de parte da água utilizada e alteração de alguns atributos na parcela de retorno. Outra característica importante é a derivação, que significa a extração ou captação dágua em um dado ponto na quantidade e qualidade pretendida, quando a dimensão qualidade é também considerada. A retirada

\footnotetext{
${ }^{9}$ Tipo de uso que altera a disponibilidade da reserva, como consumo humano e animal, e irrigação. Os usos não consuntivos conservam fixas as disponibilidades, como navegação, pesca e geração de energia.
} 
dágua de um local provoca uma diminuição na disponibilidade hídrica ${ }^{10}$, o que pode afetar outros usos, sendo fonte potencial de conflitos.

Cada tipo de atributo ait, segundo Randall (1987), pode ser algébricamente expresso da seguinte maneira:

$$
\begin{gathered}
a_{1 t}=g_{1}\left(N_{v}, X_{t}\right) \\
a_{2 t}=g_{2}\left(N_{v}, X_{t}\right) \\
\cdot \\
a_{s t}=g_{s}\left(N_{v}, X_{t}\right) ;
\end{gathered}
$$

que vai depender de $N$, que é um vetor de insumos do sistema natural e de $X$, que é um vetor de insumos controlado pelo homem, incluindo o esforço de captação.

A existência do atributo depende do sistema natural e da tecnologia. O atributo também varia no espaço geográfico. Se uma região possui condições climáticas, geológicas e hidrológicas que propiciem, em qualquer época, grande disponibilidade dágua em relação à demanda, a água, embora útil, não terá um valor econômico. Estritamente, não será vista como um recurso escasso. O atributo necessário para irrigação é, neste caso, atendido apenas pelo ambiente natural. Quando o ambiente não atende satisfatoriamente aos atributos da água para irrigação, a variável $X_{t}$ de (1) ganha importância. No Nordeste brasileiro, isto pode ser comprovado pelo desenvolvimento e uso de tecnologias e medidas de combate histórico às secas nas suas mais distintas formas.

\footnotetext{
${ }^{10}$ Fato comum no Nordeste brasileiro nos anos secos.
} 


\subsection{A Dimensão Espacial}

A principal referência geográfica para análise e manejo dos recursos hídricos é a Bacia hidrográfica. Trata-se de um espaço geográfico, delimitado por um contorno natural, topograficamente estabelecido. Toda água precipitada sobre a Bacia escoa por um sistema de cursos dágua conectado e acaba por passar em um único ponto, o exutório, situado no curso principal (Giansanti, 1993).

2.1 1. O ambiente natural a ser estudado

O objeto do presente estudo é um projeto de irrigação pública inserido na Bacia hidrográfica do Curu. Dentre as 11 Bacias hidrográficas do Estado do Ceará, esta é a mais importante quanto ao aproveitamento agrícola.

Segundo SRH (1994), a Bacia drena aproximadamente uma área de $7.900 \mathrm{~km}^{2}$, e o rio principal é o Curu, que nasce na Serra do Céu e percorre $150 \mathrm{~km}$ até o mar. Seus principais afluentes são os rios Caxitoré e o Canindé. A Bacia engloba 16 municípios e, segundo o IBGE, a população total residente na área na época do censo de 1991 era superior a 227 mil habitantes, sendo 65\% na zona rural. A Figura 1 mostra a localização da Bacia no Estado do Ceará.

$\mathrm{Na}$ parte abrangida pelo litoral, chove em média mais de $1.000 \mathrm{~mm}$ por ano. Mas, no sentido norte-sul, este índice cai para uma média de $600 \mathrm{~mm}$. Cerca de $90 \%$ da chuvas ocorrem no $1^{\circ}$ semestre, com $60 \%$ a $70 \%$ nos meses de março a maio. $O$ coeficiente de variação das séries anuais de chuva ultrapassa $30 \%$.

A temperatura média é de $32^{\circ} \mathrm{C}$ e, no período de verão, a umidade relativa do ar oscila de $50 \%$ a $60 \%$. Uma das principais características do clima diz respeito à forte insolação, variando de 2.650 horas/ano a quase 3.000 horas/ano. 
Quanto à geologia, predominam na área duas importantes formações. A sedimentar, englobando as coberturas fluvio-aluvionais e que representa $35 \%$ da área total. Já as rochas cristalinas estão situadas mais nas zonas do sertão e são consideradas praticamente impermeáveis, comportando-se como aquuiferos em porções descontínuas. As rochas cristalinas têm capacidade de acumulação restritas às zonas fraturadas. Em muitos casos, somente estas formações geológicas representam possibilidades de se conseguir água, mesmo em pequenas quantidades e não raro com alto teor de sais.

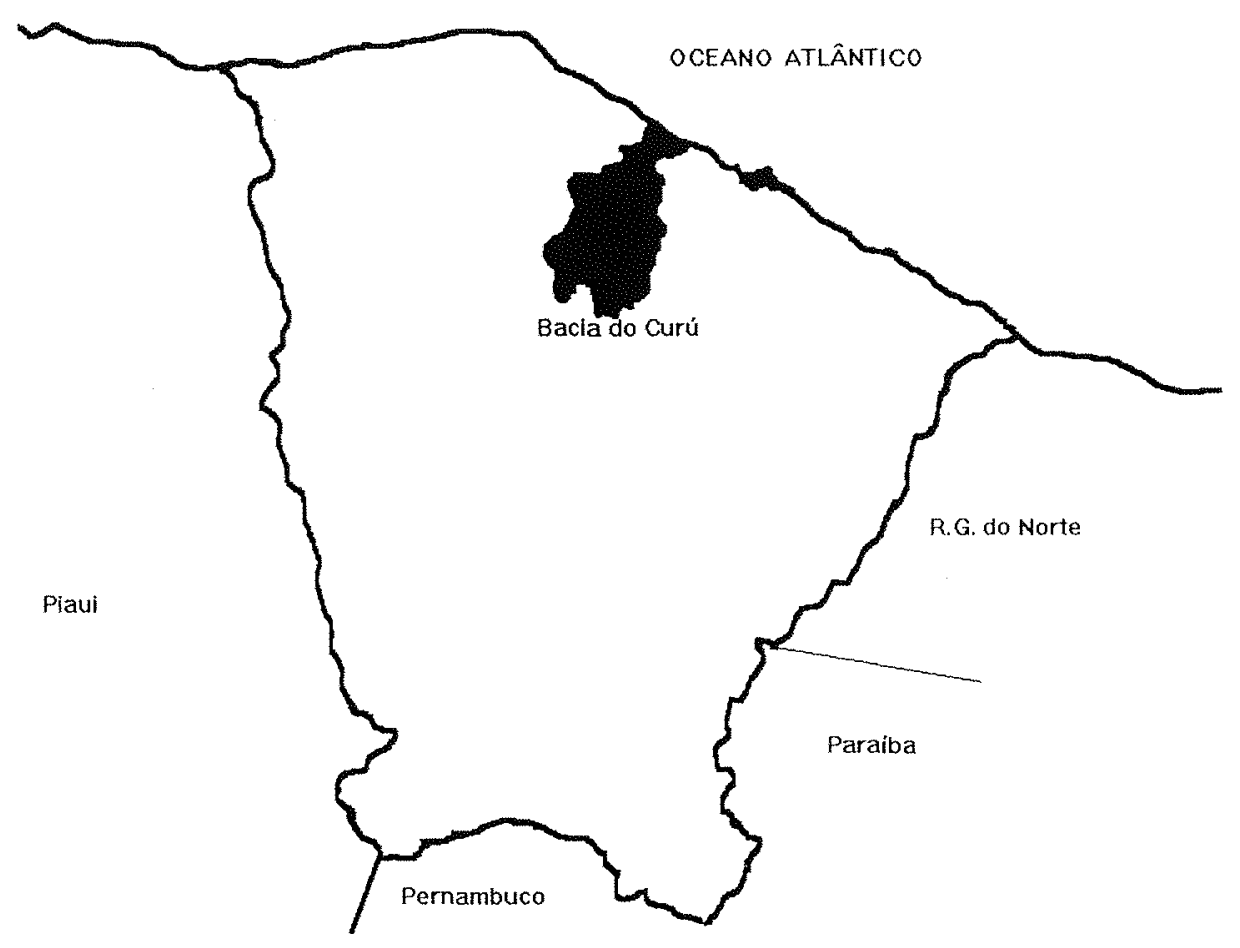

Figura 1. Localização geográfica da Bacia do Curu no Estado do Ceará. 
A área total irrigada na Bacia, em 1995, era de 8.881 ha e existe uma demanda reprimida. A demanda potencial de irrigação é de 30 mil ha (SRH, 1995) ${ }^{11}$. A cana de açúcar é a cultura mais importante, com $42 \%$ da área total cultivada na Bacia, seguida do coco, com $15 \%$ da área total cultivada. Entre as culturas alimentares destaca-se o feijão, ocupando uma área de 1.414 ha. A EMBRAPA, atualmente, vem pesquisando tecnologias poupadoras de água, como irrigação localizada e por gotejamento. Existe grande interesse em viabilizar a expansão da área cultivada e ampliar o potencial de irrigação, principalmente em fruticultura.

A Bacia serve de suporte para distintas atividades econômicas, o que implica usos diversos e alternativos dos recursos hídricos. Na Bacia do Curu, além da irrigação pública empregando 1.139 famílias, existe a irrigação privada, desenvolvida por 265 pequenos, médios e grandes proprietários, distribuídos nas áreas que margeiam o rio Curu. Existem cadastrados, na Bacia, 777 pescadores e 480 vazanteiros $^{12}$.

O presente estudo se propõe a abordar apenas o uso da água na irrigação em um projeto público federal, especificamente no projeto Curu-Paraipaba, sem considerar os reflexos deste uso frente a opções na Bacia.

2.1.1.1. A área de estudo

O estudo será feito no perímetro irrigado Curu-Paraipaba ${ }^{13}$, no Município de Paraipaba, Estado do Ceará, que possui as seguintes coordenadas geográficas:

- Latitude $3^{\circ} 30^{\prime} \mathrm{S}$

- Longitude $39^{\circ} 15^{\prime} \mathrm{W}$.

"Cadastramento dos usuários de água bruta da bacia do Curu. - Relatório final- VBA CONSULTORES e Engenharia de Sistemas Hídricos Lida.

${ }^{12}$ Expressão regional para produtores que residem e exploram terras umidas das margens dos açudes públicos. As disponibilidades de terra vão aumentando, na medida que o volume dágua diminui no verão.

${ }^{13}$ As informaçōes climáticas, geológicas e hidrológicas referentes à área de estudo foram obtidas de relatórios anuais, boletins técnicos-gerenciais, estudos e publicações diversas do DNOCS. 
A figura 2 mostra a localização do projeto dentro da Bacia. É um projeto público federal, desenvolvido por pequenos irrigantes em lotes com área média de 4,02 ha. O gerenciamento é feito conjuntamente, pelo DNOCS e pela Cooperativa dos Irrigantes em virtude do projeto se encontrar atualmente em processo de emancipação. Um fator importante considerado para seleção da área de estudo foi o fato do projeto ser o maior do Estado do Ceará.

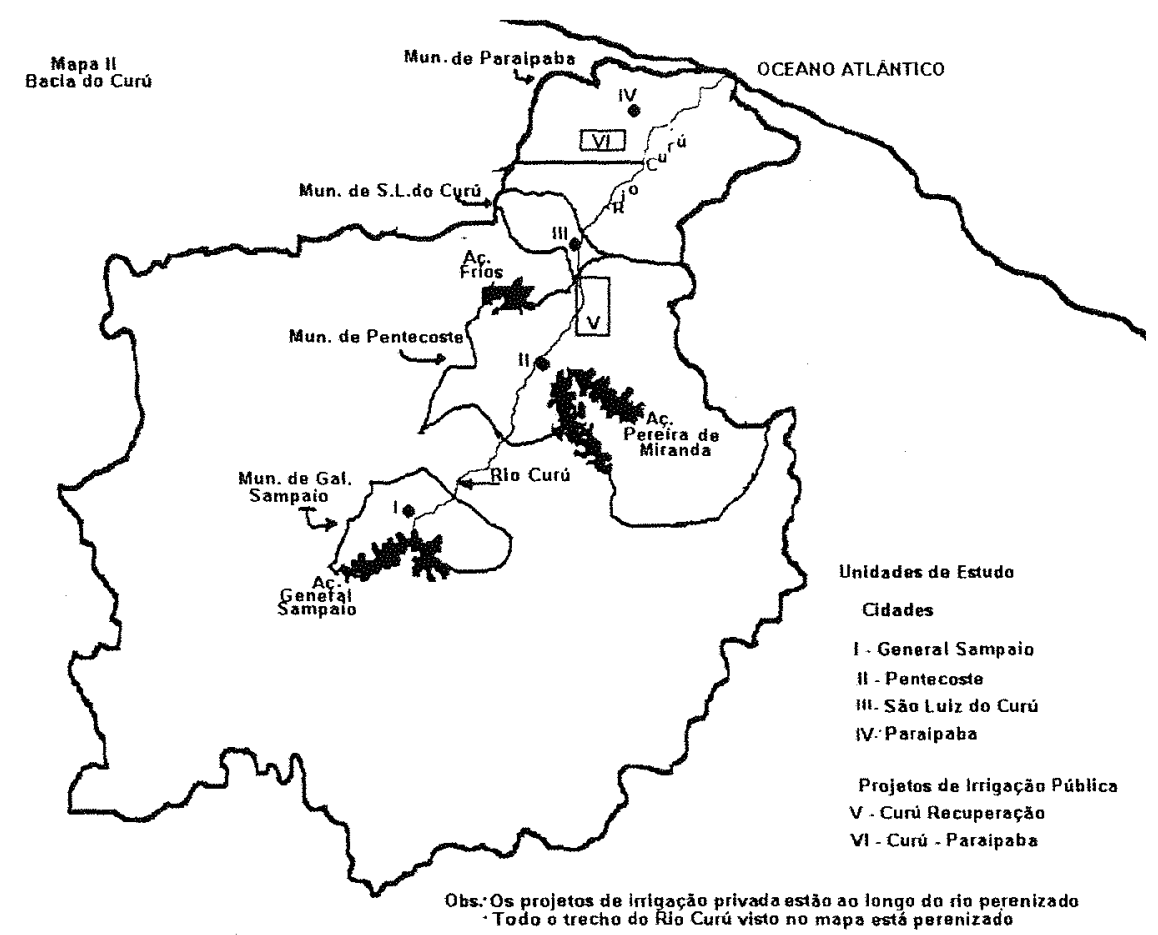

Figura 2. O projeto Curu-Paraipaba no contexto da Bacia do Curu.

O perímetro Curu-Paraipaba está à margem esquerda do rio Curu e dispõe de água dos reservatórios General Sampaio (322 milhões de $\mathrm{m}^{3}$ ), Pereira de Miranda (395 milhões de $\mathrm{m}^{3}$ ) e Caxitoré (202 milhões de $\mathrm{m}^{3}$ ), com capacidade total de acumular 919 milhões de $\mathrm{m}^{3}$. O inicio do perímetro dista $90 \mathrm{~km}$ de Fortaleza, com acesso através da rodovia BR-222 até o Distrito de Croatá, daí seguindo-se pela CE-135. 
$\mathrm{Na}$ sua quase totalidade, a área encontra-se assentada numa unidade geomorfológica denominada tabuleiro, com solos do tipo bruno não cálcico e podzólicos vermelho amarelo eutrófico. Os solos são classificados nos tipos II e III pelo Bureau of Reclamation. Pela classificação de Koppen, o clima da área é do tipo Aw, quente e úmido, com chuvas de verão/outono. A pluviometria média anual é da ordem de 1.108 $\mathrm{mm}$, com desvios acentuados em decorrência da distribuição irregular das chuvas. $O$ trimestre mais chuvoso é o de março/maio, respondendo por $70 \%$ do total das precipitações. No semestre janeiro/junho, este índice supera 95\%. A temperatura média anual é de $26,8^{\circ} \mathrm{C}$, com máxima de $35^{\circ} \mathrm{C}$ em fevereiro e mínima de $18^{\circ} \mathrm{C}$ em julho. A insolação anual está próxima de 2.600 horas e a evaporação potencial anual é de 2.811,6 mm, em média. A formação vegetal fora do perímetro é de xerófilas, típicas da caatinga, de regiões com longos períodos de estiagens, com baixa disponibilidade de recursos hídricos superficiais e subterrâneos durante a estação seca.

A superfície total desapropriada para implantar o projeto foi de 12.347 ha, podendo ser irrigados $65 \%$ desta área. O projeto foi desenvolvido por etapas. A implantação da primeira etapa teve início no ano de 1974, tendo-se concluído em 1980. Em 1995, encontravam-se assentadas 522 famílias, explorando uma área irrigada de 1.317,53 ha (COGERH, 1995). A implantação da segunda foi iniciada em $1987 \mathrm{e}$ concluida em 1995, quando contava com 285 irrigantes explorando 657,8 ha. Cada família tem um lote agrícola com cerca de 3,22 ha e um residencial com 0,8 ha.

A maior parte da renda dos irrigantes, segundo o DNOCS (1993), provém do lote agrícola $(91,8 \%$ ), sendo que 3,5\% conta com aposentadoria, 2,3\% tem outro imóvel rural e 2,4\% tem empregos ou possuem pequenos negócios. No ano agrícola de 1990, a cultura mais importante em termos de área era a do feijão, com 50,32\% do total, seguido da cana-de-açúcar e do milho, com $17,05 \%$ e $10,1 \%$, respectivamente. O plantio de coco vem crescendo de forma acentuada a cada ano. Em 1990, o coco em produção participava com 3,79\% da área total cultivada e, em 1995, os dados do cadastro indicavam uma participação de $14,5 \%$ da área. Neste período, houve grande redução no 
plantio de culturas de subsistência. O mamão também vem sendo bem explorado, participando com $6,2 \%$ da área total irrigada. A cultura mais importante é a cana-deaçúcar, com $51,5 \%$ da área cultivada. Portanto, as 3 culturas mais importantes do projeto participam com $72,2 \%$ da área total cultivada, sendo, por ordem de importância, a canade-açúcar, o coco e o mamão.

As forrageiras apresentam destaque em termos de área total cultivada, mas observa-se reduzido esforço despendido no seu cultivo. Isto significa uma irrisória quantidade de recursos e de maiores cuidados por parte do irrigante na condução da exploração de forragens ${ }^{14}$. Estas, ocupam áreas marginais, e são utilizadas exclusivamente para alimentação dos animais pertencentes ao irrigante. Outra razão, que talvez possa explicar a importância da área com forrageiras, foi a introdução da pecuária mista no início da década de 90 , com o apoio de crédito fornecido pelo Banco do Nordeste do Brasil (BNB).

O sistema de irrigação predominante é por aspersão convencional. O perímetro conta com uma estrutura central de bombeamento, composta por 4 conjuntos de motobombas verticais, suspensos dentro dos poços de sucção individuais, que serve a primeira etapa. $\mathrm{Na}$ segunda etapa existem duas estações de bombeamento. A união da estação principal com o canal de adução se dá através de uma tubulação paralela de aço (dupla) com extensão de $845,00 \mathrm{~m}$ e diâmetro de $1.372 \mathrm{~mm}$, com vazão de $5,1 \mathrm{~m}^{3} / \mathrm{s}$. A estação principal de bombeamento eleva a água para um canal aberto, cuja extensão é de $6.356 \mathrm{~m}$, servindo à primeira etapa.

${ }^{14}$ As informações sócioeconômicas da área de estudo são baseadas no documento "Perímetro Irrigado CuruParaipaba/Plano de Ação Global", elaborado por Serviços Integrados de Assessoria e Consultoria Ltda (1993). 


\subsection{A Dimensão Temporal}

Descrevem-se aqui as modificações que ocorrem nos atributos quando a água é utilizada em seus múltiplos propósitos, ao longo do tempo. A dimensão temporal é representada pelo ciclo hidrológico que mostra o estado ou ciclo da água na natureza como um recurso renovável. Neste período, existem várias fases. A água é normalmente submetida a evaporação, precipitação, interceptação, infiltração e escoamento superficial; estas três últimas, ao chegar ao solo. Algumas dessas etapas podem não ocorrer e a frequiência da irregularidade de ocorrência em uma ou demais fases pode levar à escassez ou excesso em determinado espaço geográfico por unidade de tempo.

O ciclo hidrológico condiciona as atividades agrícolas; determina as épocas em que o produtor cumpre as diversas fases das explorações. $\mathrm{O}$ inicio, desenvolvimento e término de todos estes estágios, dentro do ciclo hidrológico, representam um ano agrícola. Ele pode ser dividido em 2 (dois) períodos ${ }^{15}$ : o primeiro período (das chuvas) de março a junho e o segundo período (das secas), de julho a fevereiro.

No primeiro período, são exploradas as culturas de sequeiro e, no segundo, as culturas irrigadas. As culturas de sequeiro são supridas por água das chuvas em todo o seu ciclo. Quando ocorrem irregularidades na quantidade e distribuição das chuvas ${ }^{16}$, existe a necessidade de complemento hídrico a partir dos reservatórios ou diretamente dos rios.

As culturas de sequeiro ou irrigadas que apresentam uma ou duas safras em cada período podem ser chamadas de culturas temporárias. São formadas e colhidas dentro de um mesmo ano agrícola. Aquelas que são implantadas e apresentam resultados seguidos em vários anos são permanentes, e algumas, que possuem ciclo intermediário, são usualmente classificadas de semi-perenes. Utilizam água das chuvas e,

\footnotetext{
${ }^{15}$ Obviamente, no semi-árido, estes períodos não são rígidos

${ }^{16}$ Fenômeno conhecido no Nordeste como "veranico".
} 
complementarmente, dos reservatórios nos períodos de estiagens, seja nos veranicos ou na estação seca (no segundo semestre do ano).

A dimensão temporal desempenha importante papel na curva da demanda. Dependendo do prazo considerado, a distinção entre fatores fixos e variáveis é importante. O longo prazo é definido como um período suficientemente longo, quando todos os fatores podem variar. O curto prazo pode apresentar múltiplos casos. Num extremo, tem-se a situação em que todos os fatores variam, menos um. No outro limite, tem-se o período de produção, quando apenas um fator varia. Este é o enfoque dado neste estudo. A produção deve ser vista como sendo monoperiódica, ou seja, ocorre independente dos períodos anteriores e posteriores ao do estudo.

No longo prazo, existe um período de ajustamento da curva de demanda, que é mais elástica do que a de curto prazo.

Quando se consegue armazenar mais de $3 / 4$ de capacidade total de acumulação, a disponibilidade dágua nos açudes General Sampaio e Pentecoste, na maioria dos anos, é suficiente para atender às necessidades do projeto (DNOCS, 1993). Se não houvesse ocorrência de anos secos, total ou mesmo parcialmente, e com a atual demanda, a água poderia ser considerada um bem livre. Rigorosamente, não haveria um problema de economia de recursos hídricos.

Uma situação hipotética pode ilustrar esta situação. Considere-se uma região que não tenha as limitações climáticas do semi-árido nordestino. Os rios são permanentes e praticamente não existe nenhuma possibilidade de colapso no abastecimento dágua e o custo de captação seja igual a zero.

A Figura 3 mostra as curvas de demanda dágua, $D_{1}$ e $D_{2}$, e a curva de oferta $S_{O}$, representando o limite de vazão ditado pelas restrições naturais. Tomando-se a demanda $D_{1}$, inexiste a necessidade de poupar água e a quantidade utilizada deve ser Q1. Os irrigantes nada pagarão pela água. Mas, esta situação é estimulante para a entrada de novos projetos de irrigação. 


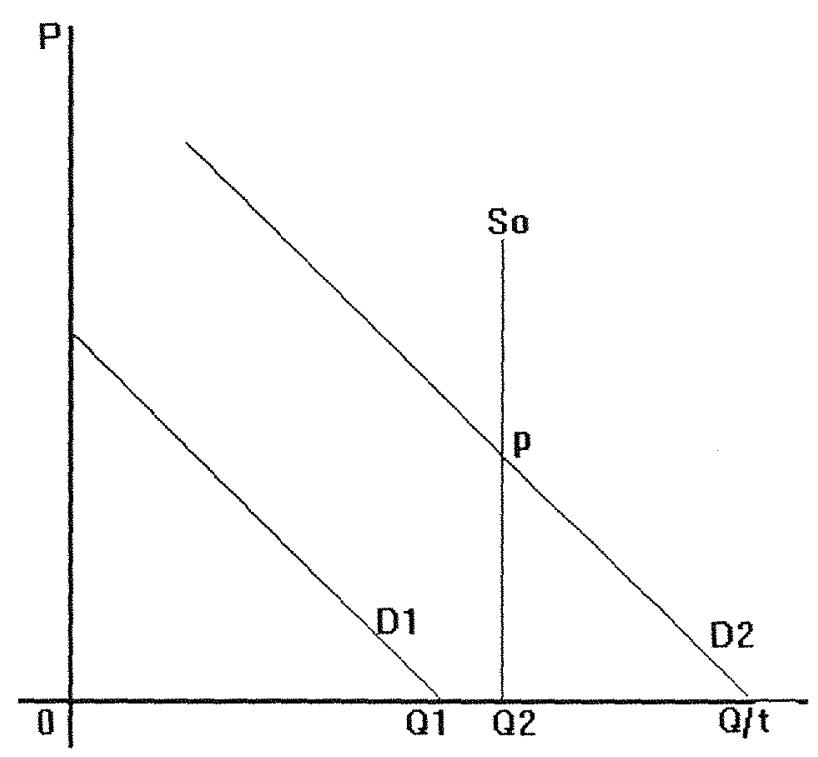

Figura 3 - O impacto econômico resultante do deslocamento da demanda dágua.

O tempo passa e a curva de demanda desloca-se para $\mathrm{D}_{2}$. As condições naturais de suprimento permanecem em $\mathrm{S}_{\mathrm{O}}$. Agora, não existe mais água para atender toda a demanda. O equilíbrio entre $D_{2}$ e $S_{O}$ é obtido com um preço igual a p. Nestas circunstâncias, existe efetivamente um problema econômico (de racionamento).

Outra situação é representada na Figura 4. Os solos que margeiam o rio não são propícios à prática da irrigação, seja por uma forte limitação física e/ou química. Mas, existe uma área extremamente favorável para irrigação, a uma distância razoável do rio. Existe uma demanda potencial $D_{1}$, não atendida, já que a oferta dágua é $S_{0}=0$. Seria necessária alguma providência para transportar água. Admita-se que os estudos de viabilidade demonstraram que a melhor solução seria desviar o curso do rio, de modo que a área propícia ficasse nas margens do curso desviado. Considere-se, ainda, que o desvio do rio não cause nenhuma perturbação ecológica e o custo marginal de suprimento seja igual a zero. 


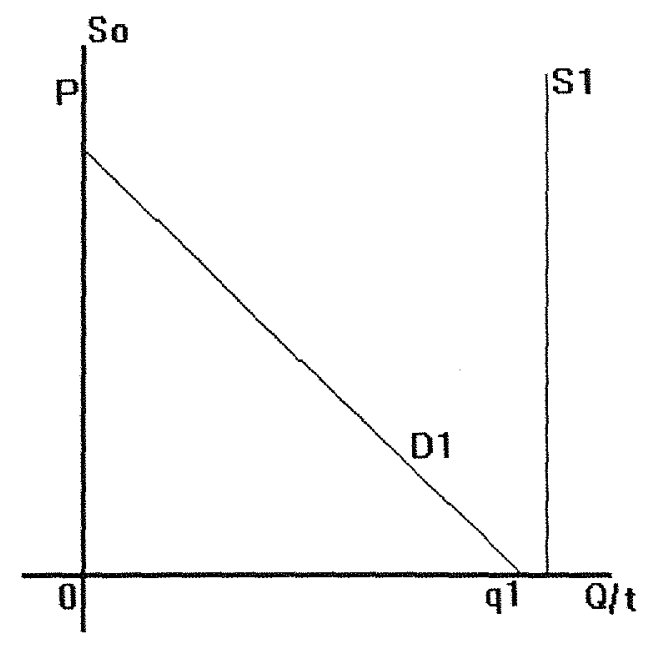

Figura 4 - O impacto econômico resultante do deslocamento da oferta dágua.

Observe-se que, na segunda situação, foram necessários recursos (I) para desviar o rio. Na primeira, o vetor de insumos foi suprido apenas pela natureza. Existe, portanto, uma taxa de juros i que deve refletir o custo de oportunidade dos recursos empregados no desvio do rio. Se os irrigantes com a demanda $\mathrm{D}_{1}$ nada pagam pela água, este custo não será coberto. Para amortizar o investimento I feito no desvio do rio num dado período de tempo $t$, os irrigantes agora devem pagar algo pela água. Uma política tarifária deve ser estabelecida. Mas, como o custo marginal é zero e os produtores dispõem agora da quantidade q1 de água, o preço será também igual a zero. Os ganhos anuais decorrentes do investimento feito com o desvio do rio serão dados pelo excedente Opq $1^{17}$, que os produtores outrora não detinham. A natureza do contrato préinvestimento é o que vai ditar as formas de ressarcimento.

Retornando ao caso do projeto Curu-Paraipaba, ali, como em todo semi-árido, existe sempre a possibilidade da ocorrência de secas. Caso contrário, se não existissem os reservatórios, uma análise econômica da água, num ano agrícola qualquer no segundo

\footnotetext{
${ }^{17}$ Toda área sob a curva da demanda D1.
} 
semeste, sempre mostraria um quadro como o da Figura 4, nas condições de demanda $D_{1}$ e oferta $S_{O}$. O investimento na infra-estrutura hídrica possibilitou o deslocamento de $S_{0}$ para $S_{1}$.

Mas, a ameaça regular de secas totais ou parciais, com duração de um, dois ou mais anos é um fato concreto. Segundo o DNOCS (1993), não é fácil encontrar solução que permita aumentar a segurança no suprimento dágua em período de seca prolongada. Isto porque o incremento dos estoques estratégicos resulta fatalmente em maiores perdas por evaporação. Ao contrário, a redução dos estoques via aumento da vazão destinada a irrigação aumenta o risco de tornar o quadro ainda mais crítico se ocorrer seca no(s) ano(s) seguinte(s). Daí a importância do enfoque econômico dado à água no semi-árido nordestino.

\subsection{A Dimensão Quantidade}

Qualquer um dos usos possíveis de recursos hídricos impõe exigências quantitativas próprias, de modo que é fundamental determiná-las. Uma das medidas é a vazão de escoamento, que é o volume do fluxo que passa via uma determinada seção, na unidade de tempo. Esta é a quantidade do recurso hídrico disponível. Os escoamentos efetivamente disponíveis decorrem de dois tipos de aproveitamentos. As vazões naturais em trânsitos, cujo volume de utilização pelos projetos de irrigação é mínimo em razão da irregularidade do regime e periodicidade dos rios. Este é um exemplo típico de recurso fluxo. Abstraindo a dimensão qualidade, pode-se quantificá-las da seguinte forma (Randall, 1987):

$$
F_{t}=R_{t}+W_{t}
$$


onde: $F_{t}$, é a quantidade fluida no tempo $t, R_{t}$ é a quantidade utilizada no tempo $t ;$ e, $W_{t}$ representa às perdas.

Porém, no semi-árido, o conceito relevante é o estoque de água. A quantidade é valorizada pelo porte do depósito (reserva) e o atributo de quantidade também considera as formas de extração do recurso. Com a construção de reservatórios, o DNOCS deveria procurar a adequada manipulação de um dado estoque dágua. Se esta não fosse represada, escoaria para locais onde teria menor valor. Do ponto de vista conceitual, trata-se da transformação de um recurso fluxo em um recurso fundo. Isto pode ser expresso da seguinte maneira (Randall, 1987):

$$
S_{t}=\sum_{r=1}^{t-1}\left(F_{r}-R_{r}-W_{r}\right)+F_{t} \geq R_{t}
$$

onde: $S_{t}$ é o estoque total de água representado pelo somatório dos acúmulos líquidos dos períodos prévios (t-1), mais o fluxo verificado no tempo t. Obviamente, o uso $R_{t}$ não pode exceder o estoque líquido acumulado nos períodos prévios mais o fluxo do período atual, ou seja, $R_{t} \leq S_{t}$. 


\section{REVISÃO DE LITERATURA}

Nesta parte da pesquisa, serão apresentados, inicialmente, alguns trabalhos que mostram o referencial teórico do conceito de demanda derivada, seguidos de estudos empíricos sobre o assunto. Complementa-se este capítulo com as investigações efetuadas no Nordeste brasileiro, e no Ceará, referentes a projetos de irrigação pública, onde predominam o cálculo de tarifa dágua e rentabilidade destes projetos.

A revisão será explorada dentro de um contexto que se fundamenta no conhecimento das funções de resposta à produção, em relação à água. Aplicando-se derivadas parciais, obter-se-ia o produto marginal da água que, multiplicado pelo preço do produto, forneceria o valor do seu produto marginal.

Randall (1987), afirma que a oferta da indústria pode ser expressa por:

$$
Y_{i}^{s}=f\left(P y_{i}, P x_{j}, P \bar{y}_{\ldots .}\right), \quad \text { sendo } \bar{y}=\text { todo } \mathrm{Y} \neq \mathrm{Y}_{\mathrm{i}}
$$

onde, $\mathrm{Y}_{\mathrm{i}}^{s}$ é a oferta da indústria de $\mathrm{Y}_{\mathrm{i}}$ sendo determinada pelo preço do produto $\mathrm{Py}_{\mathrm{i}}$, o preço dos fatores $\mathrm{Px}_{\mathrm{j}}$, o preço de outros bens $P \bar{y}$, e outras variáveis não especificadas.

Trabalhando com uma função de produção, pode-se determinar a produtividade marginal de cada fator, ou seja: 


$$
P M g X_{j}=\frac{\Delta Y_{i}}{\Delta X_{j}}
$$

onde $P M g X_{j}$ é o produto marginal do fator $j, Y_{i}$ é a produção do i-ésimo produto e $X_{j}$ é a quantidade do j-ésimo fator. Para determinar o uso eficiente do fator, quando os preços $P_{y}$ e $P_{x}$ são paramétricos, o valor do produto marginal do fator é igual ao seu preço:

$$
V P M g X_{j}=P y_{i}\left(\frac{\Delta Y_{i}}{\Delta X_{j}}\right)=P x_{j}
$$

Para determinar o uso eficiente de um fator, segundo Randall (1987), dados os preços dos produtos e dos recursos em concorrência perfeita, o $\mathrm{VPMg}_{\mathbf{i}}$ de $\mathrm{X}_{\mathrm{j}}$ deve ser igual ao seu preço e a demanda derivada por $\mathrm{Xj}$, pode ser expressa por:

$$
X_{j}^{d}=f\left(P y_{i}, P x_{j}, P x_{k}, P y_{k}\right)
$$

sendo: $x_{k}=$ todo $x \neq x_{j}$, e $y_{k}=$ todo $y \neq y_{i}$.

Esta função mostra que $X_{j}^{d}$ é a demanda derivada de $X_{j}$ como função do preço do produto $P y_{i}$, do preço do fator $P x_{j}$, dos preços de outros insumos $P x_{k}$ e dos produtos $P y_{k}$, que podem ser complementares ou substitutos na produção. No modelo acima, todos os fatores estão variando. É uma perspectiva de longo prazo.

Ao analisar a demanda por fatores, Friedman (1971) utilizou as equações abaixo, onde o índice a poderia representar o fator variável e o índice $\mathbf{b}$ os demais fatores mantidos fixos; 


$$
R M g \cdot P M g_{a}=C M g_{a}
$$

$$
R M g \cdot P M g_{b}=C M g_{b}
$$

isto é, receita marginal $(R M g)$ multiplicada por produto marginal do fator $\left(P M g_{a}\right)$ é igual ao custo marginal do fator $\left(C M g_{a}\right)$. Em livre concorrência tanto no mercado de produtos quanto no de fatores, as $R M g$ serão iguais ao preço do produto $\left(P_{y}\right)$ e os custos marginais de cada fator serão iguais aos seus respectivos preços, $P_{a}$ e $P_{b}$, reduzindo as expressões acima a:

$$
\begin{aligned}
& P y \cdot P M g_{a}=P_{a}, \\
& P y \cdot P M g_{b}=P_{b} ;
\end{aligned}
$$

onde se expressa a igualdade do valor do produto marginal de um fator e o preço desse fator, em mercados de livre concorrência.

Considerando-se os índices a e b, Friedman (1971) afirma que o valor do produto marginal de a só pode ser interpretado como a curva de demanda de a, se os demais fatores, no caso, representados por $\mathbf{b}$, se mantiverem fixos. Nesta situação, o único ajuste possível diante de uma variação do preço de a seria alterar sua quantidade empregada. Se b variar, o produto marginal dos outros fatores passa a depender da quantidade de a empregada. Nesse ajuste, a produtividade marginal de a também será influenciada. Na posição final, o preço de a também será igual ao seu valor do produto marginal, embora o ponto não mais esteja no valor inicial da curva do valor do produto marginal. 
Para estimar a curva da demanda derivada pelos recursos naturais, Agüero (1996) inicia com uma função de produção de um bem final $Q$, de cujo processo produtivo participam os recursos naturais $T$ e os demais fatores $L$, num equilíbrio competitivo. Então;

$$
\begin{array}{cc}
Q=f(T, L), & \text { função de produção } \\
P_{q}^{s}=R^{s}+W^{s}, & \text { preço de oferta } \\
P_{q}^{d}=R^{d}+W^{d}, & \text { preço de demanda }
\end{array}
$$

onde:

$P_{q}^{s}-\quad$ preço de oferta do bem final;

$P_{q}^{d}-\quad$ preço de demanda do bem final;

$R^{S}$ - renda ou remuneração de oferta do recurso natural necessário para produzir uma unidade do produto final;

$R^{d}$ - renda ou remuneração de demanda do recurso natural;

$W^{S}$ - remuneração de oferta dos outros fatores produtivos;

$W^{d}$ - remuneração de demanda dos outros fatores produtivos.

Shumway ${ }^{18}$, citado por Agüero (1996) efetuou estudos empíricos sobre demanda derivada e apresentou vários métodos de avaliação econômica da água, tais como, o da função de produção, valor residual, renda capitalizada, custo de uso, custos

${ }^{18}$ C. R. Shumway, "Derived demand for irrigation water. The California aqueduct", Southern journal of agricultural economics, vol 5, n², p.195-203- December 1973. 
diferencias e de programação linear. Agüero (1996) apresenta resultados ${ }^{19}$ obtidos nos últimos anos, em pesquisas efetuadas nos EUA, sobre o valor e preço da água destinada a irrigação que podem ser resumidos na Tabela 1 .

O método residual tem sido um dos mais utilizados em estudos sobre demanda de água (Young, 1986). O autor explicita uma versão detalhada do método residual, apresentada adiante, e sua aplicação só é valida no modelo competitivo, sendo que 2 (dois) postulados deverão ser atendidos. O primeiro é que o preço de cada recurso seja igual ao seu respectivo valor do produto marginal (VPMg). O segundo é que, se o valor total do produto for distribuído nas respectivas remunerações de cada recurso de acordo com a sua produtividade marginal, o valor do produto será totalmente exaurido. Young (1986) afirma que, no caso em que a água seja um bem intermediário, como na irrigação, a sua função de demanda é equivalente à do valor do seu produto marginal da água.

Tabela 1 - Resenha de algumas pesquisas sobre o preço da água, feitas nos EUA, destacando as culturas, métodos e autores. Período 1973 - 1984.

\begin{tabular}{llcll}
\hline Ano & Culturas & US\$/Pes cúbicos $^{\text {T }}$ & Método & \multicolumn{1}{c}{ Autores } \\
\hline 1973 & sorgo & 4 & valor residual & Kelso, Martin, \\
1973 & algodão & 236 & valor residual & Kelso, Martin \\
1979 & sorgo & 133 & valor residual & Martin e Snider \\
1979 & alface & 157 & valor residual & Martin e Snider \\
1979 & cebola & 1280 & valor residual & Martin e Snider \\
1980 & sorgo $^{2}$ & 21 & função de produção & Saliba \\
1980 & tomate $^{3}$ & 536 & função de produção & Saliba \\
1984 & alfafa & 38 & valor residual & Bush e Martin \\
1984 & algodão & 133 & valor residual & Bush e Martin \\
\hline
\end{tabular}

Fonte: Agüero, 1993.

${ }^{1} \mathrm{Um} \mathrm{m}^{3}$ equiivale a 35,31 pés cúbicos

${ }^{2}$ Estudo feito no Arizona-USA

${ }^{3}$ Idem.

19 Dados citados pelo autor a partir de Diana Gibbons. The economics value of water. Washington D.C. Johns Hopkins Univ. 1986. 
Uma aplicação do método residual foi feita por Palácios (1977) no distrito de irrigação de Rio Mayo, no Estado de Sonora (México). Para o ciclo agrícola 1973-74, havia dados disponíveis de áreas e volumes utilizados em 10 culturas temporárias. O objetivo do estudo era determinar o custo de oportunidade da água. Inicialmente, foi estimada uma curva de renda líquida (RL) total, com base na RL de cada cultura e respectivos consumos de água, ordenados acumuladamente desde o cultivo com maior $\mathrm{RL}$ até o de menor. $\mathrm{O}$ valor estimado foi de 0,28 pesos por $\mathrm{m}^{3}$ de água. Mas, o autor não define claramente o que representa esta RL, podendo não ser aquela somente destinada a remunerar a água. Isto significa que neste resíduo podem estar incluídos os pagamentos de outros fatores, e neste caso, segundo Young (1986), o valor obtido poderá ser superestimado.

Loomis (1994) fez um estudo com o objetivo de identificar formas de incentivo econômico para redução de consumo dágua destinada a projetos de irrigação na Califórnia (EUA). Um dos modelos utilizados foi o de computable general equilibrium, que permite estimar a curva de VPMg da água, para uma série de reduções sucessivas de $10 \%$ dágua. A primeira redução em $10 \%$ com relação à que vinha sendo utilizada resultou num valor de US\$38,00 por acre cultivado. A cada redução de $10 \%$ de água, o produtor estava disposto a pagar mais, entre US $\$ 3,00$ a 4,00 por acre irrigado.

Sobre o método da função de produção, Chiang (1982) faz uma abordagem teórica da análise clássica versus programação linear. A análise clássica parte de uma função contínua e diferenciável em todos os seus pontos e pode ser caracterizada pelos rendimentos constantes ou não. No contexto da programação linear, as isoquantas são de proporções fixas de insumos. A isoquanta tem uma forma de $\mathrm{L}$ e o ponto situado no ângulo é necessariamente a combinação mais eficiente de insumos. Além disso, existe o pressuposto de rendimentos constantes na programação linear. Este método foi utilizado por Teixeira (1990), que estimou o preço sombra da água em 5 perímetros de irrigação sob jurisdição da Companhia de Desenvolvimento do Vale do São Francisco (CODEVASF). Os dados foram obtidos nos boletins técnicos da CODEVASF, referentes a novembro de 1985. O modelo consistiu na maximização de uma função 
objetivo representando receita líquida do irrigante, sujeito às restrições de mão-de-obra, terra e água. Uma limitação do trabalho foi a não inclusão do fator capital nas restrições. Para geração da curva da demanda de água, o autor estimou sucessivos "preços-sombra" de água, resultantes da variação continuada de sua disponibilidade em cruzeiros de novembro de 1985. Os "preços sombra" da água variaram de zero a $\mathrm{Cr} \$ 20,14 / 1000 \mathrm{~m}^{3}$ no período de outubro a março e de zero a $\mathrm{Cr} \$ 9,17 / 1000 \mathrm{~m}^{3}$ de abril a setembro, no projeto Bebedouro-BA.

Quanto aos estudos no semi-árido nordestino, somente nos últimos anos, passaram a receber maior atenção por parte dos especialistas. A maioria visava a fornecer subsídios à política de cobrança dágua e tratava de conhecer a capacidade de pagamento dos irrigantes. Isto ganhou importância no Ceará com a criação da lei estadual 11.996, de 24.07.92, criando o Sistema Integrado de Gestão dos Recursos Hídricos do Ceará, tendo como objetivos a outorga de uso e promover a cobrança da água para irrigação.

Mas os estudos não tem levado em consideração estimativas da demanda de água para irrigação. Isto impede contemplar a possibilidade efetiva do preço fixado para água ser muito diferente daquele que os produtores estariam dispostos a pagar. Não avaliam fontes de ineficiências na distribuição. Nestas condições, pode ocorrer que os produtores estejam operando com custos superiores aos benefícios ou vice-versa, o que significa que a água não esteja sendo racionalmente alocada e o lucro não seja maximizado.

Azevedo \& Lemos (1989) estudaram a eficácia da irrigação pública, através dos produtores agrícolas instalados nas áreas irrigadas do DNOCS, sob o ponto de vista de produtividade e renda, no período de 1977 a 1984. Foram estudados 8 (oito) perímetros irrigados, sendo, respectivamente, um na Bahia, Pernambuco, Paraíba e Piauí e 4(quatro) no Ceará. Utilizando análise de taxas de crescimento, concluíram que os rendimentos físicos reduziram-se nas culturas de feijão e milho nos projetos de Icó e Morada Nova no Ceará e São Gonçalo na Paraíba. As causas foram manutenção inadequada de infra- 
estrutura de irrigação, seguida de deficiências da assistência técnica e falta de crédito. Quanto à renda líquida, definida pelos autores como a diferença entre o valor bruto da produção e custos correntes, apresentaram desempenho heterogêneo. Nos perímetros onde havia algumas agroindústrias, como no caso de Curu-Recuperação e CuruParaipaba, no Ceará, a renda foi mais elevada do que nos demais. Naqueles em que se exploram culturas de subsistência, com inadequado sistema de comercialização, o desempenho da renda foi ruim. Projetos como Lagoas-PI, São Gonçalo-PB e Moxotó-PE apresentaram crescimento da renda com taxas negativas. Neste último grupo, os produtores não tinham condições de pagar a tarifa.

França \& Pereira (1990) analisaram a capacidade de pagamento do pequeno irrigante do Nordeste, utilizando dados obtidos em pesquisa direta junto a produtores residentes em projetos sob intervenção do DNOCS e da CODEVASF. Foram aplicados 255 questionários nos seguintes projetos: Curu-Paraipaba e Morada Nova, no Ceará, Cachoeira II, Moxotó e Nilo Coelho, em Pernambuco, Caldeirão, no Piauí, Vaza-Barris, Mandacaru e Estreito, na Bahia, e Gorotuba em Minas Gerais. Utilizando o método de comparação em grupos, obtiveram 3 (três) classes de renda média por produtor/ano, sendo respectivamente menos de US $\$ 1.400,00$, entre US $\$ 1.400,00$ e US $\$ 2.800$, e acima de US\$2.800,00 em valores de dezembro de 1987. Esta renda, segundo os autores, seria destinada a amortizar a parcela, reduzir ou eliminar subsídios embutidos no preço cobrado pela água e energia e até mesmo efetuar reinvestimentos. No estrato de maior renda, constam os projetos Moxotó e Mandacaru. No segundo estrato, estão os projetos Gorotuba, Nilo Coelho e Morada Nova e no terceiro estrato, Caldeirão, VazaBarris e Curu-Paraipabada. O perímetro denominado Estreito apresentou renda média negativa. Com maior renda, situavam-se aqueles perímetros que exploravam culturas dirigidas para a agroindústria, que, inclusive, financiavam assistência técnicas aos irrigantes. Os resultados também mostraram que o custo da água sobre o custo total variou entre $0,87 \%$ e $6,93 \%$. Em termos absolutos e a preços de dezembro de 1987, o menor custo da água foi de US\$3,59/ha em Vaza-Barris, e o maior de US $\$ 35,67 /$ ha no projeto Nilo Coelho, que tinha um nível de subsídio de $75 \%$ na época do estudo. 
Gondim Filho (1992) estimou a tarifa dágua para a etapa I do projeto CuruParaipaba localizado no Ceará, baseado no princípio econômico de recuperação de custos. Nesse caso, a tarifa deve ser fixada em um valor que permita o ressarcimento das despesas anuais de operação, manutenção e administração da infra-estrutura de irrigação. O modelo utilizado para o cálculo, foi:

$$
T=\frac{\left(C_{1} \cdot K_{1}+C_{2} \cdot K_{2}\right)}{V}
$$

onde:

$T$ - Tarifa de água paga pelo usuário, em $\mathrm{Cr} \$ / \mathrm{m}^{3}$;

$C_{1}$ - Coeficiente que varia no intervalo de zero a unidade, permitindo incorporar o nível de subsídio da parcela correspondente à amortização dos investimentos públicos nas obras de infra-estrutura;

$K_{1}$ - Valor correspondente à amortização anual dos investimentos públicos nas obras de infra-estrutura, em $\mathrm{Cr} \$$

$C_{2}$ - Coeficiente que varia no intervalo de zero à unidade, permitindo incorporar o nível de subsídio da parcela correspondente ao valor das despesas anuais de administração, operação e manutenção da infra-estrutura, em Cr\$;

$K_{2}$ - Valor correspondente às despesas anuais de administração, operação e manutenção de infra-estrutura; e,

$V$ - Volume de água disponível $\mathrm{em}^{3}$.

O valor estimado foi de US $\$ 27,00 / \mathrm{mil} \mathrm{m}^{3}$, a preços de outubro/91 enquanto os produtores deveriam pagar US $\$ 18,00 / \mathrm{mil} \mathrm{m}^{3}$ referente às despesas apenas com energia elétrica. Mesmo assim, cerca de $30 \%$ dos produtores encontravam-se inadimplentes na 
época da pesquisa. O autor não explica as possíveis razões desta constatação e apresenta como solução, aumentar o subsídio governamental, via redução da tarifa.

Assirati (1994) fez uma avaliação das políticas de irrigação no Nordeste e estimou que as inversões e subsídios dados nesta área representaram algo entre 4 (quatro) e 5 (cinco) bilhões de dólares no período 1970-89. Comparando os planos governamentais com a realidade objetiva, o autor considera que os estudos de viabilidade foram muito otimistas nas justificativas de inversões. Como os resultados econômicos obtidos nos projetos foram muito aquém das expectativas iniciais, criou-se forte dependência do orçamento da União para o custeio da operação e manutenção dos projetos. Segundo o autor, as subvenções do governo federal aos irrigantes, em 1989, eram de US\$ 500,00/ha/ano. O que comprometia o desempenho econômico destes projetos era:

a) perdas de áreas dotadas de infra-estrutura de irrigação por causa de problemas de salinização;

b) baixo índice de utilização dos solos, raramente atingindo 1,5 vez/ano;

c) exploração de culturas de reduzido valor, produzindo baixo volume de recursos destinados à manutenção. Estes recursos são supridos precariamente pelas dotações orçamentárias dos órgãos executores;

d) contraditoriamente, tem sido dada prioridade a novos projetos de investimento relativamente a manutenção dos existentes. $O$ volume de recursos federais previstos para novos investimentos em recursos hídricos no período do estudo foi cinco vezes superior ao destinado à manutenção; e,

e) as tarifas dágua não têm sido capazes sequer de custear os dispêndios operacionais dos projetos.

Algumas pesquisas analisaram a rentabilidade de projetos de irrigação pública no Ceará sob condições de risco.

Melo Filho (1992) efetuou pesquisa com o intuito de determinar a rentabilidade 
das explorações agropecuárias sob condições de risco do perímetro Curu-Paraipaba. O método utilizado para estimar as funções de distribuições cumulativas de probabilidade dos indicadores foi o de simulação de Monte Carlo, onde chegou à seguinte conclusão: com a atual combinação de atividades e o nível tecnológico utilizado, os irrigantes tendem ao fracasso econômico, mesmo considerando-se o subsídio atual inserido na tarifa dágua. As razões são as baixas produtividades obtidas pelas culturas e os preços deprimidos recebidos pelos produtores da maioria dos produtos. Com isto, o processo de emancipação que visa a transferir para a organização de irrigantes todos os encargos assumidos inicialmente pelo DNOCS não tem perspectiva de êxito, salvo se forem alocados recursos públicos para este propósito, conclui o autor.

Alguns estudos acadêmicos têm incorporado o fator risco nas pesquisas, como o exemplo de Biserra (1994), que procurou determinar a rentabilidade das unidades de exploração do perímetro Morada Nova, no Ceará. O autor estimou os seguintes indicadores econômicos: renda liquida, lucro, taxa de remuneração do capital e valorização da mão-de-obra familiar. Foi utilizado o método de simulação de Monte Carlo para obter a função de distribuição cumulativa de probabilidade dos indicadores. Os dados foram obtidos através de entrevistas com 36 irrigantes selecionados ao acaso, no segundo semestre de 1987 . Os custos e receitas foram determinados dentro de três cenários:

1) com a tarifa cobrada efetivamente no perímetro;

2) com a tarifa cobrindo apenas os custos anuais de administração, operação e manutenção; e,

3) tarifa cobrindo todos os custos, inclusive os referentes à amortização dos investimentos públicos.

Os resultados mostraram que a agricultura no perímetro é altamente rentável sob as condições do primeiro e segundo cenários, cuja tarifa é subsidiada. Não existem, nos 2 (dois) cenários, riscos de prejuízos e mostra-se, inclusive, que o governo pode reduzir o volume de subsídios. No terceiro cenário, que adota o princípio de cost 
recovery, o produtor não teria condições de se adequar em certos anos. Os valores dos indicadores são menores que os permitidos. Para o governo adotar este princípio visando a acelerar a emancipação destes projetos, o autor conclui que a produtividade das culturas existentes deve ser incrementada. Recomenda, também, introduzir culturas com maior valor de mercado e, se possível, recorrer ao seguro agrícola.

Utilizando os mesmos cenários propostos por Biserra (1994), Araújo (1995) procurou avaliar economicamente modelos de exploração típicos do Perímetro CuruParaipaba, no Ceará. O estudo buscava identificar a combinação ótima de culturas à luz dos indicadores econômicos pré-selecionados. Através de programação linear, foi extraída a seguinte conclusão de ordem geral: caso o governo venha a retirar ou reduzir os atuais níveis de subsídios da tarifa dágua, a simples recombinação das atividades atuais não possibilitará manter os irrigantes no Perímetro. Somente com a introdução de culturas mais rentáveis e com melhor nível tecnológico para algumas das atuais, seria possível viabilizar a exploração agrícola do Perímetro, sem subsídio para a água. $\mathrm{O}$ autor não considera o fato de que para melhorar o nível tecnológico, seria necessária a tomada de medidas que permitissem ampliar o estoque de capital.

Uma conclusão comum de todos estes estudos é que os irrigantes de projetos públicos necessitam de subsídios para continuar em suas atividades. Os métodos e bases conceituais utilizados têm sido orientados no semi-árido para o lado da oferta de água. A preocupação é saber se os custos de suprimento dágua podem ou não ser recuperados e se a fixação de tarifas seguem esta orientação.

Se os estudos e análises têm sido feitos apenas pelo lado da oferta, é temeroso utilizar seus resultados conclusivos com fins de subsidiar a formulação de políticas tarifárias. Os anseios dos consumidores podem, em boa parte, estar sendo substituídos por decisões de natureza político-administrativa, única forma de fixar tarifas quando só a oferta é considerada e não se conhece a curva da demanda.

Lanna (1994) apresentou dois modelos para tarifação de água bruta no vale do Curú. Estes contemplam os investimentos e os custos de operação e manutenção de 
sistemas de suprimento. O valor encontrado foi de US\$ $490,00 / 1000 \mathrm{~m}^{3}$ para a tarifa de água, em agosto de 1994. Neste caso, os usuários pagariam por toda a água, mesmo da parcela que não usariam. A razão de custos tão altos deve-se à inclusão dos pesados investimentos públicos efetuados, junto com as despesas de operação e manutenção. Estes custos seriam todos repartidos pelos usuários. Também considera que a oferta dágua estivesse sempre garantida, o que, nas condições do semi-árido, pode vir a não ocorrer. Em janeiro de 1995, o autor introduziu uma modificação no seu modelo de cálculo da tarifa. Pondera o volume utilizado por usuário de per se, não mais pelo volume total utilizado por estes, mas pelo volume regularizável; e pondera a área de cada usuário, não pela soma das áreas irrigáveis, mas pela área total irrigável com base na oferta dágua. Com este procedimento, a tarifa cai para US $\$ 188,60 / 1000 \mathrm{~m}^{3}$. A redução da tarifa no segundo modelo deve-se à divisão dos custos com o Estado, uma vez que a água não utilizada e nem utilizável pelos usuários não seria cobrada.

O Banco Interamericano de Reconstrução do Desenvolvimento (BIRD), em estudo coordenado por Briscoe (1990), feito sobre abastecimento urbano de água no Nordeste, concluiu que os preços eram altamente subsidiados, prendendo o consumidor numa espécie de "armadilha de baixo nível”. Segundo o banco, as pessoas demandam mais água do que o sistema é capaz de fornecer e, para racionar o suprimento, a companhia responsável reduz o número de horas de serviço. Como os sistemas não são confiáveis, as pessoas não estão dispostas a pagar muito pelo serviço e a autoridade não pode cobrar preços realistas. As receitas não são suficientes para gerenciar o sistema adequadamente e a confiabilidade se deteriora cada vez mais. Num estudo efetuado no Ceará, no município de Apuiarés, Briscoe (1990), utilizando o método de avaliação contingencial, determinou que as pessoas estariam dispostas a pagar US $\$ 0,80 / \mathrm{m}^{3}$ de água tratada na área estudada. Em Fortaleza, usuários situados na faixa de consumo de 0 a $10 \mathrm{~m}^{3}$ por mês pagavam o equivalente a US $\$ 0,38 / \mathrm{m}^{3}$ na época do estudo. Talvez este seja um dos fortes motivos da recente exigência por parte do Banco para estimativas das curvas de demanda dágua para abastecimento urbano; é um condicionante para liberação de créditos destinados a investimentos em sistemas de abastecimento no Nordeste. Num 
futuro próximo, talvez isto possa vir a ser uma exigência com relação à água destinada à irrigação. 


\section{METODOLOGIA}

\subsection{O Modelo Teórico}

\subsubsection{A contribuição da teoria microeconômica ao estudo}

Este estudo situa-se no campo da microeconomia, utilizando a teoria da produção e da demanda a curto prazo na análise do uso da água destinada a irrigação.

A teoria microeconômica trata das relações entre agentes econômicos: a firma, que produz bens e serviços; o consumidor, que os procura; e o mercado, que faz a coordenação entre estes agentes. Como resultado desta contínua interação, forma-se o preço. Este é a expressão quantitativa do valor que têm os bens, em termos monetários. Se houver condições para o completo desenvolvimento dos mercados, os preços oferecerão incentivos para a produção, produz rendas pessoais, distribui bens entre consumidores e constantemente informa sobre escassez relativa (Randall, 1987).

Os mercados podem ser melhor explicados através de conceitos básicos como demanda, oferta e equilíbrio. A curva da demanda estabelece o preço máximo com que o consumidor irá se defrontar e ainda assim comprar o bem. A este valor, o indivíduo é indiferente entre adquirir ou não o bem (Varian, 1994). Mas, desde que todos os indivíduos compram num mercado ao mesmo preço, se houver informação completa, a curva de demanda do mercado pode ser obtida pela soma horizontal de todos os indivíduos. Já o conceito de oferta representa o valor mínimo que os ofertantes aceitariam para suprir aquela quantidade. 
A curva da oferta representa custos marginais (CMg) (Young, 1986). Na Figura 5 , qualquer quantidade utilizada do bem (recurso) abaixo de $q^{*}$ significa perdas. Se a curva da demanda representando o benefício marginal superar o custo marginal, ganhos poderiam ser obtidos aumentando-se a quantidade demandada. À direita do ponto de equilíbrio c, ocorre o contrário, ou seja, os custos marginais excedem os benefícios marginais e a redução de perdas só poderia ocorrer pela redução da quantidade demandada.

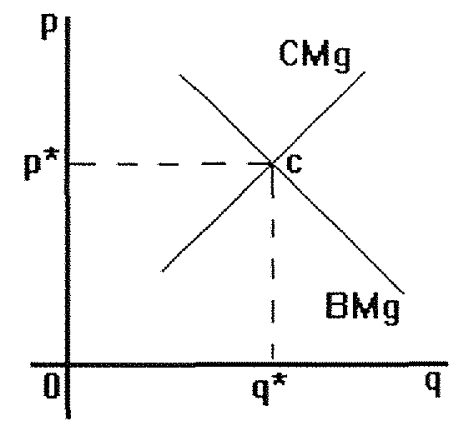

Figura 5. Representação gráfica do modelo benefício-custo.

Então, o locus de maior interesse é dado no ponto c, onde

$$
B M g=C M g
$$

Isto é, benefício marginal $(B M g)$ é igual ao custo marginal $(C M g)$. Todos os fatores utilizados para produzir foram remunerados pelo seu custo de oportunidade. Este constitui-se num dos conceitos-chave da economia (Mishan, 1975). Para algum bem ou serviço, o custo de oportunidade representa o seu valor em algum emprego alternativo, mas, como pode haver mais de um emprego alternativo, trata-se daquele que encerra o maior valor. Então, todos os pontos fora de c são sub-ótimos. 
Mas, existem bens (recursos) que não são transacionados em mercados ordinários e um grande número de recursos naturais enquadram-se nesta categoria. Segundo Agüero (1996, p.34), "a renda da escassez aparece ante os acréscimos da demanda por cada unidade dos recursos naturais e, desde que a quantidade total seja fixa, a única saída para equilibrar o mercado é a subida dos preços. Uma queda na demanda se traduzirá numa queda dos preços". Este processo é diferente para outros bens da economia. Com os bens produzidos pelo homem, é possível que a oferta se ajuste à demanda para neutralizar as oscilações de preços. Então, na Figura 5, tratando-se de um recurso natural, a curva de oferta poderia ser representada por uma linha vertical.

Uma peculiaridade importante dos recursos naturais é a sua heterogeneidade e diversidade de uso. Tomando o exemplo específico da água, pressupõem-se distintos enfoques analíticos em função do uso considerado. Água destinada para um determinado uso interfere nas disponibilidades para outros, os usos não são independentes. Neste caso, o valor e o preço da água poderiam ser analisados sob a óptica de um modelo amplo, de equilíbrio geral, onde fossem considerados todos os elementos da economia, inclusive externalidades. Mas, se o objetivo da análise focaliza para apenas um uso, pode ser considerado o modelo de equilíbrio parcial.

Neste estudo, os conflitos distributivos para cada uso não serão discutidos. O enfoque se restringirá a dotação feito pelo governo para o projeto de irrigação. $O$ problema distributivo será considerado apenas do ponto de vista interno do projeto.

A Figura $6 a$ mostra que existe uma quantidade de água $X_{t}$ disponível num reservatório, e por decisão política são estabelecidas cotas para distintos usos. Se toda a água fosse destinada ao atendimento do projeto, não haveria um problema de economia de recursos hídricos a ser estudado. A quantidade $X_{t}-X_{d}$ é uma quota que pode ser destinada para preservação do ecossistema ${ }^{20}$, permanecendo nos reservatórios, pode ser

\footnotetext{
${ }^{20}$ No Nordeste brasileiro, o governo estabelece esta cota incluindo reserva estratégica para o ano seguinte, reduzindo o risco de desabastecimento das cidades em caso de seca. Para este cálculo são levadas em consideração as perdas por evaporação que são expressivas.
} 
destinada ao uso urbano, culturas não relevantes de projetos públicos e/ou empreendimentos privados.

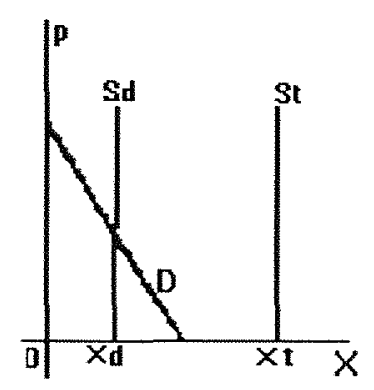

Figura 6a. Água disponível no reservatório, oferta e demanda de água às culturas relevantes.

A Figura $6 \mathrm{~b}$ mostra as disponibilidades de água exclusivamente para uma dada área de estudo e representada pela quantidade $X_{d}$ segundo a oferta fixa $S_{d}$. Com a estimativa da demanda $\mathrm{D}$, completa-se o mercado de água que será o principal elemento de análise do presente estudo.

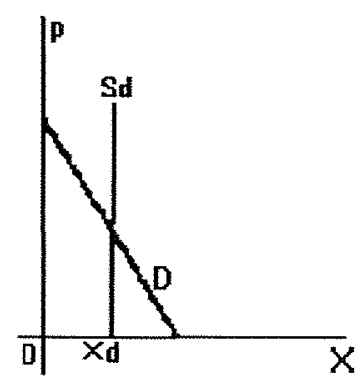

Figura 6 b. Oferta e demanda de curto prazo de água das culturas relevantes. 
Porém outras peculiaridades sobre o mercado de água são pressupostas. Assume-se que o seu preço é determinado exogenamente, não há livre informação entre usuários e existem dificuldades de mobilidade entre os produtores.

Este sistema possui seus arranjos institucionais e culturais específicos, que aloca recursos e fixa preços ditados pelo governo, via mecanismos administrativos, sem refletir maior ou menor grau de escassez relativa.

Nesses casos, o problema pode ser resolvido através da criação de um mercado hipotético. Young (1986) argumenta que pode ser feita uma idealização intelectual de um sistema de mercado. Isto com base na premissa de que as necessidades pessoais dos indivíduos (produtores e consumidores), orientam o emprego dos recursos na produção, distribuição e consumo.

A Figura 5 representa o modelo analítico de benefício-custo e adota os mesmos princípios de um sistema de mercado idealizado (Young, 1985). O autor considera a idéia de que o maior esforço numa análise benefício-custo é a derivação dos "preços sombra" que orienta o sistema de mercado apropriadamente e pode guiar decisões alocativas. Os "preços sombra" de bens ou fatores são aqueles prevalecentes num sistema de mercado perfeitamente competitivo (Mishan, 1975). Utilizando-se "preços sombra", fica estabelecido um sistema de trocas em termos monetários, exatamente como ocorreria num mercado ideal (Young, 1986).

A determinação de preços-sombras tem múltiplas aplicações na economia. No mundo real, é freqüente a existência de fontes de ineficiência econômica fazendo com que os preços observados no mercado eventualmente não reflitam a escassez relativa do bem ou recurso.

Além disso a expressão "preço sombra" foi estendida às estimativas de bens e fatores que não têm preço, ou não os têm satisfatoriamente (Mishan, 1975). Em estudos sobre economia de recursos naturais isto é muito comum, principalmente no caso de bens não- rivais ou com atenuação no direito de propriedade. Estes bens podem ser avaliados de várias formas e Mishan (1975).recomenda as seguintes: i) adotando-se os 
preços de coisas semelhantes em outra parte; ii) calculando-se o preço de um bem implícito na decisão do governo de empreender determinados projetos; iii) calculando as externalidades mediante referência aos preços de mercado.

\subsubsection{Métodos de avaliação}

Os métodos para avaliar os recursos naturais devem se fundamentar, na teoria econômica, observando-se as especificidades de cada recurso (Agüero, 1996). No caso da água, existem alguns métodos apropriados e cada um pode ser utilizado em função da natureza do estudo. Apresenta-se, em seguida, os principais métodos utilizados.

\subsubsection{Método da programação linear}

É um método que faz parte da programação matemática ${ }^{21}$ e que consiste em resolver problemas de otimização, através da maximização de uma função objetivo, sujeita a restrições. Para obter a curva de demanda da água, por exemplo, a função objetivo poderia ser a renda líquida do produtor derivada da utilização de sua parcela de terra. Maximizando a função objetivo, e explicitando restrições quanto à disponibilidade dos fatores, a solução do problema levará a estimativa dos seus "preços sombras". Simulando mudanças relativas quanto à disponibilidade de cada fator, pode-se determinar diferentes "preços sombra", para cada uma destas quantidades.

Uma vantagem deste método sobre aqueles que utilizam otimização clássica é que as restrições estão em forma de desigualdades, permitindo que a alocação seja igual ou inferior as fixadas pela restrição. Mas, as desigualdades não podem ser tratadas pelas regras clássicas de cálculo. A função de produção resultante e gerada pela solução de

\footnotetext{
${ }^{21}$ Termo geral que, além da programação linear, abrange a programação não-linear e teoria dos jogos.
} 
programação linear não é contínua nem diferenciável. Uma isoquanta gerada pela programação linear, difere da clássica porque a sua taxa marginal de substituição tende a permanecer constante em certas regiões e apresentar alterações aos saltos. Mudanças em um fator exigem mudanças proporcionais em todos os fatores. Um pressuposto básico da programação linear é que a função seja homogênea de grau 1.

\subsubsection{Método residual}

Este método permite determinar o valor do recurso hídrico por meio de análise e desagregação dos orçamentos das unidades agrícolas (Agüero,1996). Subtraindo da renda total obtida a remuneração de todos os fatores de produção empregados que não sejam água, obter-se-ia, como resíduo, o valor deste recurso. O método residual permite a determinação do valor da água por atividade agrícola.

Em qualquer área irrigada, existe um número possível de atividades agrícolas e cada uma exibe um único valor com respeito à água usada na irrigação (Young, 1986). Dado um conjunto de atividades agrícolas $i$, e de fatores de produção $j$, onde $j=(1 \ldots n)$ e considerando-se a água como o n-ésimo fator, pode-se escrever;

$$
(P X)_{i n}=V T Y_{i}-\sum_{j=1}^{n-1} P_{j} \cdot X_{i j}
$$

onde: $\mathrm{P}_{\mathrm{n}}$ é o preço da água, $\mathrm{X}_{\mathrm{in}}$ é a quantidade dágua alocada na atividade $\mathrm{i}, \mathrm{VTY}_{\mathrm{i}}$ é o valor da produção, $\mathrm{P}_{\mathrm{j}}$ e $\mathrm{X}_{\mathrm{ij}}$ são os preços e quantidades dos demais fatores com exceção da água. O termo à esquerda da eq. (17), representa a contribuição da água ao processo produtivo i. Assumindo que são conhecidas todas as variáveis da expressão, exceto $P_{n}$, ele pode ser determinado e representa o "preço sombra" da água. Relacionando o preço com a quantidade utilizada de água em cada atividade agrícola, no período e local de estudo, pode-se determinar a curva da demanda de água. 
A desvantagem do método residual é a enorme quantidade de cálculos necessários para a desagregação dos orçamentos das unidades agrícolas. Como os irrigantes de projetos públicos no Nordeste exploram uma agricultura diversificada, com áreas diminutas, a necessidade de cálculos é muito grande. A existência de inúmeros itens de custos comuns necessários a desagregação requer fortes suposições, sendo quase impossível a obtenção de boas estimativas de "preços-sombras".

Não há dados disponíveis na área do presente estudo com o nível de detalhe requerido pelo método. Estimar o valor do fator variável por resíduo, requer o pressuposto de pleno equilíbrio de todos os demais fatores num horizonte de curto prazo. Agüero (1996) acrescenta que caso se qualifique a terra e equipamentos como fixos, a individualização das "rendas e "quase rendas" seria difícil ou quase impossível de determinação. Afirma que caso existam outros insumos sem preço, ou que seus preços não sejam compatíveis, o método residual não oferece a confiança necessária.

\subsubsection{Método da demanda derivada}

O método propõe encontrar o valor da água, por derivação indireta de sua participação na geração do valor do produto final em que ela participa. Conhecendo-se a função demanda do bem final e a participação da água na oferta deste, pode-se deduzir a demanda de água para cada nível de consumo. Conforme Agüero (1996), os passos para estimar a demanda derivada, seriam:

i) Estima-se a demanda do produto irrigado i:

$$
P_{q}^{d}=f\left(Q_{i}\right)
$$


onde $P_{q}^{d}$ é o preço ${ }^{22}$ como função da quantidade demandada $Q_{i}$ do produto estudado.

ii) Estima-se a oferta do produto irrigado,

$$
P_{q}^{S}=f\left(Q_{i}\right)
$$

onde $P_{q}^{S}$ é o preço como função da quantidade ofertada $Q_{i}$.

Na produção do bem final $Q_{i}$, participam a água $\mathrm{X}_{\mathrm{i}} \mathrm{e}$ os demais fatores $\mathrm{X}_{\mathrm{j}}$. Pode-se obter uma função que considere a remuneração de todos os fatores menos água. Como o valor desta remuneração $\left(Z_{\mathrm{s}}\right)$ também depende da variação de $Q_{i}$ e dos preços relativos dos fatores e do produto, supondo equilíbrio competitivo, tem-se:

$$
Z s=h\left[g\left(Q_{i}\right)\right]
$$

onde $Z_{S}$ é a remuneração de todos os fatores menos de água.

iii) A curva da demanda derivada por água, por unidade do bem final, é obtida do seguinte modo:

$$
X_{q}^{d}=P_{q}^{d}-Z s
$$

22 Como se pretende determinar o valor da água, utiliza-se o preço como variável dependente. 


$$
X_{q}^{d}=f\left(Q_{i}\right)-h\left[g\left(Q_{i}\right)\right]
$$

então, para cada nível de $Q_{i}$ (bem final), deduz-se o $X_{i}$ correspondente, que é a remuneração da água.

O método da demanda derivada requer grande manipulação algébrica. Se o objetivo primordial do trabalho é estimar a demanda de água, é razoável pretender-se utilizar um método que atenda diretamente a este propósito em vez de alcançá-lo indiretamente, via demanda de produtos. Este método é bastante interessante se, além da demanda por fatores, pretenda-se fazer estimativas da demanda por produto.

\subsubsection{Método da função de produção}

Conforme mencionado anteriormente, o presente estudo trata da demanda de curto prazo dágua que pode ser estimada a partir de funções de produção, utilizando-se dados de corte seccional. As $k$ variáveis independentes e a variável dependente $Y_{j}$ representam o ponto $\left(X_{1 j}, X_{2 j}, \ldots, X_{k j}, Y_{j}\right)$, num espaço euclidiano de $(k+1)$ dimensões. Então, pode-se usar a expressão:

$$
Y_{j}=f\left(X_{1 j}, X_{2 J}, \ldots, X_{k j}\right)
$$

onde $Y_{j}$ é a quantidade produzida e as $k$ variáveis independentes, são os fatores de produção.

Este método é direto, requer cálculos mais simplificados, gera funções contínuas e diferenciáveis. Permite determinar o VPMg. de qualquer fator de produção incluído no modelo acima. Apresenta a vantagem adicional de apresentar uma grande variedade de informações sobre relações fator-fator e fator-produto. A aplicação deste método pode também fornecer indicações sobre os recursos que não estão sendo 
utilizados da forma mais eficiente, podendo orientar a formulação de políticas que possibilitem o uso ótimo de recursos.

Gibbons (1986) ${ }^{23}$, citada por Agüero (1996), afirma que o método da função de produção foi largamente utilizado na agricultura dos EUA. A autora mostra vários exemplos. Uma desvantagem do método é apresentar a possibilidade estatística de alta correlação entre as variáveis independentes, quando são utilizados dados de corte seccional (Agüero, 1996).

\subsubsection{A função de produção}

Conforme mencionado previamente, e considerando as vantagens e limitações dos métodos apresentados, o da função de produção é o que reúne o melhor referencial para atender aos objetivos do presente estudo.

Produção é um processo de transformação. Na produção, formas de materiais e energia menos valorizadas são transformadas em bens e serviços mais valorizados em benefício do homem (Randall, 1987). O processo de produção pode ser representado pela função de produção.

A função de produção indica a máxima quantidade de produto que pode ser obtida a partir de uma dada quantidade de fatores. É a representação algébrica da tecnologia. Uma função de produção descreve o que é tecnicamente viável de se produzir quando a firma faz cada combinação de fatores, selecionando adequadamente os processos de produção.

Considere-se a seguinte representação de função de produção hipotética:

$$
Y=f\left(X_{1} / \bar{X}_{2}, \ldots, \bar{X}_{n}\right)
$$

${ }^{23}$ Gibbons, D.C. The Economic Value of Water. Washington DC: Johns Hopkins Univ., 1986. 
onde: $Y$ é a quantidade produzida de um bem ou serviço; $X_{1}$ é a quantidade utilizada do fatore variável. Os demais fatores $\left(\bar{X}_{2}, \ldots, \bar{X}_{n}\right)$ são fixos.

Mantendo os demais fatores constantes e fazendo variar apenas $X_{1}$, pode-se obter uma relação que mostra o máximo da produção de $Y$, em resposta as quantidades utilizadas de $X_{1}$.

O produtor racional deverá produzir sempre num ponto onde ele possa obter o máximo lucro, dada a sua função de produção. O lucro do produtor é dado por:

$$
L=R B-C T
$$

onde: $L$ é o lucro; $R B$ é a renda bruta; e, $C T$ é o custo total. Considerando que:

$$
R B=Y \cdot P_{Y}
$$

onde: $Y$ é a produção total; $\mathrm{P}_{\mathrm{Y}}$ é o preço unitário do produto $Y$. Multiplicando-se a quantidade do fator $X_{1}$ pelo preço do fator $\mathrm{P}_{\mathrm{X} 1}$ tem-se o custo total CT;

$$
C T=X_{1} \cdot P_{X}
$$

Substituindo as eq.(26) e (27) em (25), tem-se:

$$
L=Y \cdot P_{Y}-X_{1} \cdot P_{X}
$$


A condição necessária para que $L$ seja um máximo é aquela em que a sua derivada em relação a $X_{l}$, seja igual a zero, ou seja:

$$
\frac{\partial L}{\partial X_{1}}=0
$$

Resolvendo (29), obtém-se:

$$
P_{Y} \cdot \frac{\partial Y}{\partial \mathrm{X}_{1}}=P_{X}
$$

onde o preço do produto $P_{Y}$ multiplicado pela derivada de $Y$ em relação a $X_{1}$, que representa o produto marginal de $X_{1}\left(P M g_{\chi_{1}}\right)$, é o valor do produto marginal $\left(V P M g_{X_{1}}\right)$, que deve ser igual ao preço do fator $P_{X_{1}}$. Esta é a curva da demanda de curto prazo do fator $X_{1}$.

A eq. (30) mostra que na concorrência perfeita o lucro é maximizado no ponto de utilização do fator em que o seu VPMg é igual ao seu preço.

A condição dada em (30) pode estar associada com um máximo ou mínimo. Para determinar se a função lucro é estritamente côncava, é suficiente que:

$$
\frac{\partial^{2} L}{\partial X_{1}^{2}}<0
$$

ou seja; 


$$
\frac{\left(P_{Y 1}\right) \frac{\partial \mathrm{Y}_{\mathrm{i}}}{\partial \mathrm{X}_{\mathrm{j}}}-P_{X}}{\partial \mathrm{X}_{\mathrm{j}}^{2}}<0
$$

Para que o lucro seja máximo nesse ponto, ele deve crescer a uma taxa decrescente. Portanto, a eq.(32) deve ser menor do que zero.

$$
\frac{\left(\frac{\partial Y_{i}}{\partial X_{j}}\right)}{\partial X_{j}}<0
$$

Se a eq. (32) é negativa e $P_{Y}$ é positivo, obrigatoriamente a eq. (33), será negativa e descreve a lei de retornos marginais decrescentes (Beattie \& Bruce, 1989). Isto demonstra que a curva de demanda por fator é negativamente inclinada.

A eq. (30) atende o primeiro postulado da teoria da produção, ou seja, o de que o preço do recurso seja igual ao valor do seu produto marginal, que é uma condição para escolha ótima do fator visando à maximização de lucros (Varian, 1994). Um argumento em defesa deste pressuposto foi apresentado por Friedman (1971), questionando o seguinte: $\mathrm{O}$ que ocorreria se o proprietário de um recurso pagasse por todos os outros recursos os valores de seus produtos marginais e o que sobrasse fosse maior que o $\mathrm{VPMg}$ do recurso deste proprietário? A resposta literal é que "os proprietários dos outros recursos teriam um incentivo para fazer o mesmo, eliminando a diferença" (Friedman, 1971 p.133). Caso contrário, conclui Friedman (1971, p.145), "o proprietário do recurso teria um incentivo para renunciar sua atividade presente e ceder o uso de seu recurso pelo seu $V P M g "$.

O argumento apresentado é válido depois que todos os agentes econômicos tiverem tido tempo de se ajustar às mudanças de relações de preços. Tisdel (1978, p. 212) afirma que, "só no longo prazo e sob concorrência perfeita, os recursos recebem uma taxa de retorno, ou o preço unitário, igual ao seus VPMg". 
A procura de produtos finais reflete diretamente a utilidade (Friedman, 1971). A demanda por fatores reflete isto indiretamente. O autor conclui, afirmando que "o vínculo entre estes 2 (dois) tipos de demanda é mais forte quando a quantidade exigida do fator está ligada rígida e tecnicamente a quantidade do produto".

\subsubsection{A utilização da função de produção.}

4.1.4.1. A eficiência técnica e econômica no uso dos fatores.

Um dos objetivos mais importantes perseguidos em pesquisas que envolvem economia da produção refere-se à eficiência no usos dos fatores. Esta pode ser definida como a minimização do custo para um dado nível de produção ou maximização do produto a partir de determinada quantidade de recursos.

O segundo postulado da teoria da produção assegura que, se a remuneração dos fatores de produção for de fato efetuada de acordo com suas produtividades marginais, resultará na completa exaustão do produto total no longo prazo. Esta é uma condição de equilíbrio competitivo e faz com que o lucro de todas as empresas seja zero no longo prazo (Tisdel, 1978). O autor salienta que, num regime de concorrência perfeita, a firma tende a operar com uma função de produção homogênea de grau 1, o que é confirmado por (Friedman, 1971). A derivada de uma função homogênea de grau k é uma função homogênea de grau k-1. Então, no caso específico de uma função homogênea de grau 1, uma variação proporcional de todos os insumos resulta numa variação igual do produto. É o sentido exato de rendimento constante de escala. Em funções de produção estimadas para 17 produtos agropecuários do Brasil, para relacionar rendimentos de escala com distribuição de terra, Cline (1970) concluiu que existe uma nítida tendência dos rendimentos serem de natureza constantes. 
Este postulado complementa o primeiro, quando afirma que o valor do produto marginal de um fator variável deva ser igual ao seu preço como condição necessária para maximização de lucros. Então, a mesma pressuposição deve ser válida para os demais fatores no longo prazo.

Segundo Stiegler (1970, p.122), "o teorema de Euler foi introduzido na economia para resolver o problema de verificar se cada fator produtivo está sendo pago a taxa de sua produtividade marginal". O teorema assegura que o produto total é a soma das quantidades de cada insumo multiplicadas por seus respectivos produtos marginais, onde:

$$
Y=K \frac{\partial Y}{\partial K}+L \frac{\partial Y}{\partial L}
$$

Se $Y=f(K, L)$, onde $Y$ é produção como função de $K$ (capital) e $L$ (trabalho ) e for homogênea de grau 1, apresentará rendimentos constantes à escala e todas as condições citadas anteriormente serão satisfeitas.

Neste estudo, o cerne da questão refere-se ao estudo de apenas um fator variável, no caso específico da água. Mas as funções de produção a serem obtidas contemplam um conjunto de informações relevantes sobre os demais fatores empregados no processo. É importante um exame das relações entre estes fatores e destes com o produto. Um primeiro passo para estudos da eficiência dos fatores pode ser dado através das elasticidades parciais de produção $\left(\mathrm{E}_{\mathrm{p}}\right)$, que permitem medir a influencia de cada fator, isoladamente, sobre a produção. A função de produção é uma relação eminentemente técnica e reporta-se a aspectos de engenharia. A abordagem econômica relevante requer o envolvimento indispensável das relações de preços dos fatores e do produto.

A determinação da elasticidade total de produção $\left(E_{t}\right)$ permite identificar os rendimentos à escala da função de produção. Esta análise pode sugerir recomendações que possibilitem a expansão, manutenção ou retração dos recursos alocados na produção, 
pode orientar comparações entre culturas que devam ser estimuladas em maior ou menor escala.

Alguns fatores podem estar sendo empregados fora do estágio econômico de produção. A determinação dos produtos médios (PMe) e marginal (PMg) de cada fator ganha importância para identificar em que estágio da função o fator está sendo utilizado. Para analisar o nível de uso do recurso produtivo, é necessário relacionar o valor do produto marginal (VPMg) de cada fator com o seu preço (p). Quando a relação for maior do que 1, deve-se aumentar a quantidade empregada do fator. Caso contrário, deve-se reduzir, pois o fator está sendo utilizado em quantidades excessivas. Se for igual a 1 , significa que o fator está sendo empregado no seu nível ótimo. Esta análise preliminar requer, em suma, extrair das funções de produção informações sobre elasticidades parciais de produção (Ep), elasticidades totais de produção $(\mathrm{Et})$ e valor do produto marginal (VPMg). Do mercado, serão obtidos os preços dos produtos e dos fatores.

Enquanto as quantidades dos demais fatores poderiam se ajustar aos seus preços de mercado, a quantidade de água fixada pelo governo é que vai determinar o preço deste fator. O preço da água é endógeno e sua determinação constitui-se num dos objetivos desta tese.

Dispondo-se do PMg de cada fator, pode-se determinar a taxa marginal de substituição (TMS) entre os fatores incluídos no modelo. A TMS de um fator $\mathrm{X}_{1}$ por outro fator $\mathrm{X}_{2}$ é a quantidade adicional de $\mathrm{X}_{2}$ necessária para manter inalterado o volume de produção, com a redução de uma unidade do fator $\mathrm{X}_{1}$. Então, TMSx $\mathrm{X}_{1}$ é igual a relação entre $\mathrm{PMgx}_{1} / \mathrm{PMgx}_{2}$. A combinação entre os dois fatores que proporciona o menor custo é obtida quando: $\mathrm{TMSx}_{1} \mathrm{x}_{2}$ é igual à relação inversa dos preços destes fatores. Sempre que TMSx $x_{1}>\mathrm{Px}_{2} / \mathrm{Px}_{1}$, seria recomendável substituir $\mathrm{X}_{2}$ por $\mathrm{X}_{1}$. 


\subsubsection{A demanda por um fator variável}

Dado um grupo de produtores que utilizam $k$ fatores de produção e exploram a cultura $j$, pode-se estimar a função de produção:

$$
Y_{j}=f\left(X_{1 j}, X_{2 j}, \ldots, X_{k j}\right)
$$

onde $Y_{j}$ é a quantidade produzida da cultura $j$, como função das quantidades dos fatores $X_{\mathrm{ij}}$. Considerando-se $X_{1 j}$ como o único fator variável, a eq. (30) mostra que o preço do recurso deve ser igual ao valor do seu produto marginal (VPMg), como condição para maximização de lucro. Se na função de produção for mantido apenas um fator variável e os demais ficarem fixos, pode-se derivar o produto marginal daquele fator. Com o preço do produto dado pelo mercado competitivo, pode-se estimar o VPMg do fator variável. Nestas circunstâncias, o único ajuste que pode ser feito diante de uma variação no preço do fator é alterar a sua quantidade. (Friedman, 1971). Esta pode ser considerada a curva de demanda de curto prazo pelo fator produtivo.

É isto o que ocorre no curto prazo, numa situação em que apenas um fator é variável. Mas, no longo prazo ocorrem alterações importantes. Com o aumento na quantidade utilizada do fator variável decorrente de uma eventual queda no seu preço, ocorrerão ajustes nas quantidades utilizadas dos demais fatores. Isto faz com que a curva do VPMg do fator variável focalizado se desloque. Determinando apropriadamente e unindo um ponto situado na curva inicial com um ponto da curva que se deslocou, podese estimar a demanda de longo prazo do fator. Esta apresenta-se mais elástica do que a curva estimada inicialmente. 
4.1.4.3. Procedimento analítico com as funções de demanda

Com as estimativas das demandas por um fator variável para distintos grupos de produtores, pode-se fazer uma proposta de distribuição ótima de recursos escassos.

Considere-se 2 grupos de produtores, A e B, que maximizam lucros e que estejam produzindo duas culturas diferentes, $U$ e V. Cada grupo exibe funções de produção diferentes, gerando distintas curvas de PMg de água. Derivando-se as curvas de VPMg para ambos os grupos de produtores, a partir das curvas de PMg e preços dos produtos, tem-se $\mathrm{VPMg}_{u}$ e $\mathrm{VPMg}_{v}$. Existe uma disponibilidade de água Xt para o período em que estas culturas serão exploradas pelos 2 grupos. O mercado alocaria para o grupo $\mathrm{A}$, a quantidade de água $\mathrm{Xa}$ e para o grupo $\mathrm{B}, \mathrm{Xb}$. Ambos pagariam um preço Po pela água. Então, $X t=X a+X b$. Se o preço e quantidades de água são guiados pelo mercado, o grupo A teria um excedente de Sa e o grupo B teria um excedente de Sb, conforme a Figura 7.

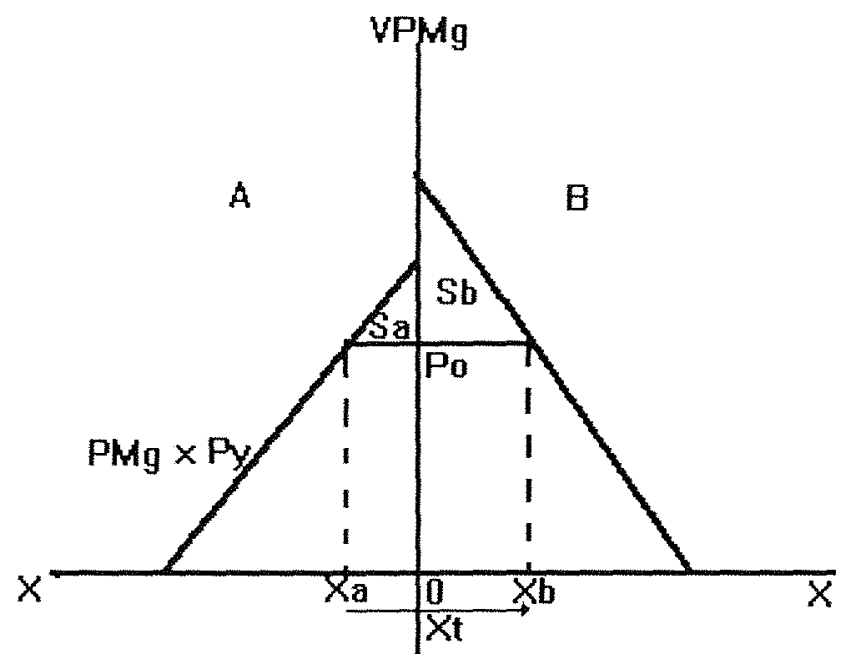

Figura 7. Alocação ótima de água entre dois produtores.

Assuma que o preço seja fixado no nível $\mathrm{P}_{1}$ (Fig.8). Se as mesmas quantidade de água fossem distribuídas, o resultado seria uma escassez de $(X d b-X b)+(X d a-X a)$ de 
água. $\mathrm{O}$ agente externo deixaria de arrecadar as áreas $\mathrm{Ra}$ e $\mathrm{Rb}$, que passariam a incorporar os excedentes de A e B. O grupo A passaria a ter um excedente de $\mathrm{Sa}+\mathrm{Ra}$ e o grupo $\mathrm{B}$ um excedente $\mathrm{Sb}+\mathrm{Rb}$. Na verdade, $\mathrm{Ra}+\mathrm{Rb}$ representam subsídios para os irrigantes, conforme a Figura 8.

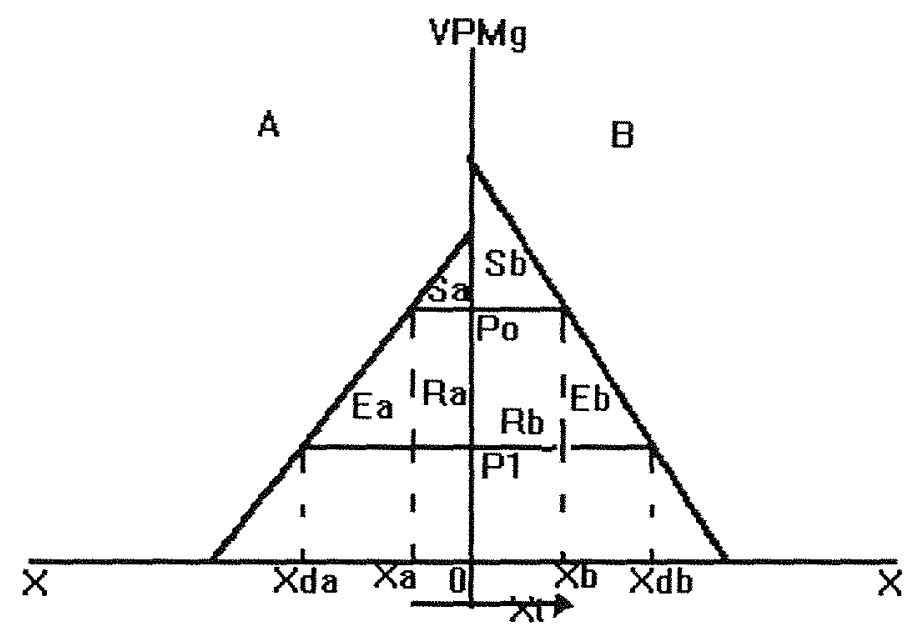

Figura 8. Alocação ótima versus alocação feita pelo governo.

Mas, além de fixar um preço abaixo de mercado, o agente externo intervém, distribuindo uma cota de água igual a Xa' para o grupo $\mathrm{A}$ e $\mathrm{Xb}$ ' para o grupo $\mathrm{B}$, conforme a Figura 9. O agente externo não conhece a curva de demanda de água de cada grupo. A alocação é feita com base na área cultivada ao invés do critério econômico, que distribuiria $X \mathrm{X}$ e $\mathrm{Xb}$, respectivamente, para os grupos A e B. Então, o grupo A, recebe $X a^{\prime}$, sendo $X^{\prime}{ }^{\prime}>X a$, e o produtor $B$, recebe $X b^{\prime}$, sendo $X b^{\prime}<X b$. Mas $X a^{\prime}+X b^{\prime}=X a+$ $\mathrm{Xb}=\mathrm{Xt}^{24}$. Como reagiriam as forças de mercado para que este voltasse ao equilíbrio?

O grupo de irrigantes $\mathrm{B}$ adquire $\mathrm{Xa}$ '- $\mathrm{Xa}$, porque a área $(\mathrm{Db}+\mathrm{Ib}+\mathrm{Kb}+\mathrm{N})$ é maior do que a área de $\mathrm{A}$, que é $(\mathrm{Da}+\mathrm{Ia}+\mathrm{Ka})$. Esta diferença de área eqüivale a $[\mathrm{N}+$ $(\mathrm{Kb}-\mathrm{Ka})]$. Embora para o agente externo, oficialmente, a quantidade disponível para

${ }^{24}$ Pode-se assegurar que os grupos continuarão recebendo a mesma quantidade Xt prevalecentes ao preço Po, porque é a única quantidade efetivamente disponível e ditada pelo sistema natural. 
cada grupo seja de $\mathrm{Xa}$ 'e $\mathrm{Xb}$ ', algum ajuste deve ocorrer. O grupo $\mathrm{A}$ pode vender água para o grupo B. Para esta quantidade de água negociada, prevalece o preço de mercado. O grupo $\mathrm{B}$ paga efetivamente para o grupo $\mathrm{A}$, a quantia $(\mathrm{Db}+\mathrm{Ib}+\mathrm{Kb})$. Como $\mathrm{Db}+\mathrm{Ib}$ é igual a $\mathrm{Da}+\mathrm{Ia}$ e $\mathrm{Kb}$ é maior do que $\mathrm{Ka}$, conforme Figura 9, é melhor para o grupo $\mathrm{A}$ receber $\mathrm{Kb}$, do que apenas $\mathrm{Ka}$. Se não for possível ocorrer trocas entre os grupos $\mathrm{A}$ e $\mathrm{B}$, além das perdas do agente externo decorrentes de $\mathrm{P}_{1}<$ Po mostradas na Figura 8 , ocorrerão perdas de excedentes dos produtores iguais a $[\mathrm{N}+(\mathrm{Kb}-\mathrm{Ka})]$ como mostra a Figura 9.

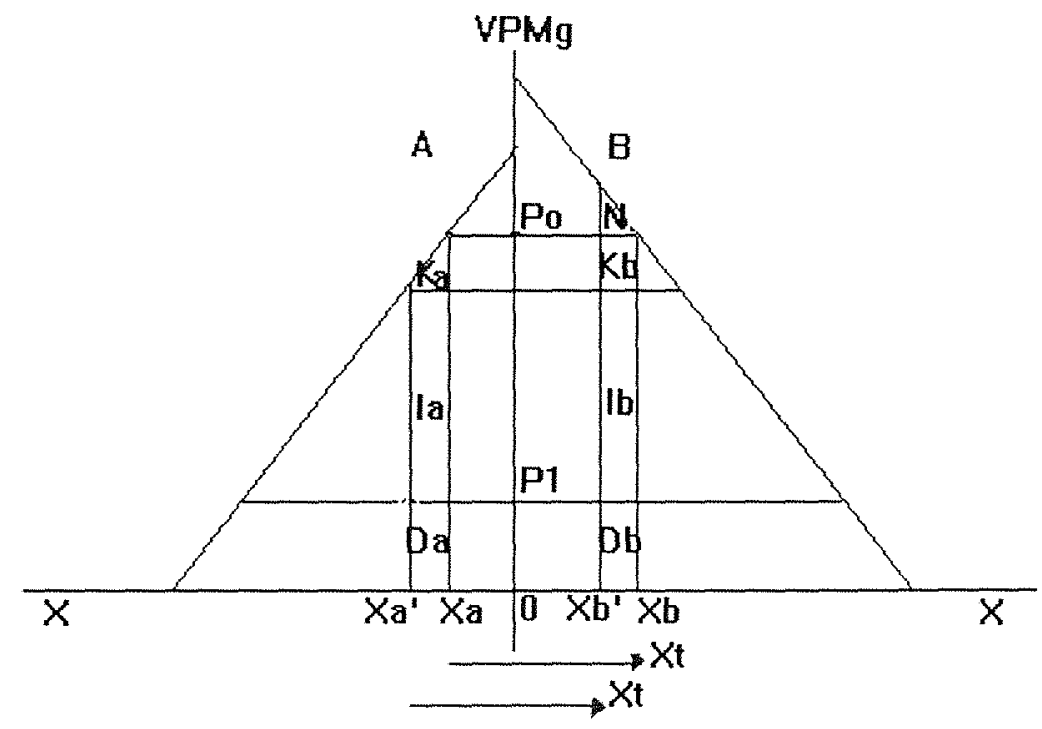

Figura 9. Ajustamento do mercado decorrente de ineficiências.

4.1.5. Disposição a pagar (DAP) por um fator de produção

A curva da demanda inversa mostra, para cada quantidade demandada, existe um preço que os consumidores estão dispostos a pagar (Varian, 1994). Em outras palavras, significa quantas unidades monetárias o consumidor está disposto a pagar pela última unidade adquirida do bem. Este é um enfoque marginalista. Em termos absolutos, a DAP total pode ser medida pela área situada abaixo da curva da demanda. É um 
conceito que se usa para medir benefícios totais. Toda esta área corresponde à avaliação máxima da sociedade para a quantidade do bem (recurso) em questão (Yong, 1986, p.158)

Quando se analisa um bem final, a sua função de demanda mostra a máxima quantidade que se está disposto a consumir deste bem, dado o seu preço. Distintamente de uma avaliação privada ou financeira de projetos, a DAP supera o real pagamento que se faz através do preço. A diferença entre a DAP e o que realmente se paga é igual ao excedente do consumidor. Ele faz parte dos benefícios totais, ainda que não represente uma transferência efetiva de dinheiro entre quem oferece o bem ou serviço e aquele que os recebe.

Se o valor efetivamente pago pelo bem (recurso) for subtraído dos benefícios totais, obtém-se o benefício econômico líquido. Esta medida tem sido muito utilizada pelos estudiosos na avaliação de bens não transacionados em mercados ordinários. Casimiro Filho \& Shirota (1997), propõem o uso do benefício líquido como medida de valor de áreas de recreação no Ceará, utilizando o método do custo de viagem.

Quando se focaliza os mercados para os fatores de produção, algumas de suas características especiais são dignas de menção. A primeira, é que trata-se de uma procura derivada. Consequentemente, o emprego e os preços dos fatores vão depender não só das condições do mercado de fatores, como do mercado dos produtos.

Quanto à água destinada para irrigação, Agüero (1996, p.209) conclui que o seu valor é equivalente ao valor do produto marginal da água, ou a diferença entre o valor do produto total obtido com esta água, e a despesa efetuada com todos os fatores fixos.

Neste particular, dois enfoques podem ser apresentados para esclarecer o conceito de DAP. A base está na definição de curto prazo, como um período dentro do qual alguns insumos são variáveis enquanto outros são mantidos constantes. Existem muitos "curtos prazos" e o número de serviços produtivos variáveis aumenta na medida em que o tempo é cada vez mais prolongado. 
O primeiro considera apenas um fator variável, mantendo-se os demais insumos/fatores fixos. Portanto, pode-se isolar o valor do produto marginal (VPMga) de um serviço produtivo, mantendo-se constante as quantidades dos outros fatores. O custo de oportunidade destes é igual a zero. A Figura 10 mostra que a área sob a curva do VPMgx é constituída das sub-áreas $V$, que representa a remuneração do fator variável e $F$, que representa a remuneração dos fatores mantidos fixos. Esta seria um equivalente ao excedente do consumidor, quando se analisa o problema sob a ótica do mercado de produtos.

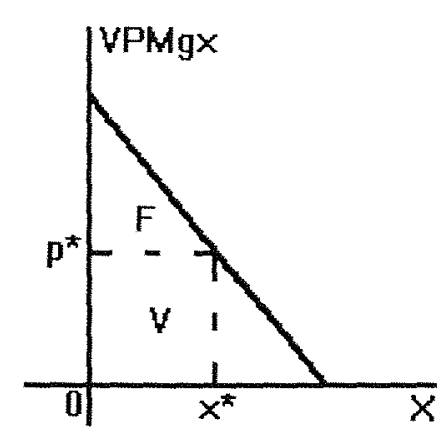

Figura 10. Valor do produto marginal de um serviço produtivo

A eq.(36) mostra que a área sob a curva do VPMgx eqüivale ao valor bruto da produção (VBP), ou seja:

$$
V B P=P y \int_{0}^{x^{*}} \frac{\partial \mathrm{y}}{\partial \mathrm{x}} \cdot d x
$$

onde, VBP é o valor bruto da produção, Py é o preço do produto e $\frac{\partial y}{\partial x}$ é o produto marginal do fator $\mathrm{x}$.

Então pode-se afirmar que DAP é igual ao VBP, que também eqüivale a 
$(V+F)$, conforme mostra a Figura 10 .

$\mathrm{Na}$ vida real, o empresário pode fazer variar alguns fatores muito mais rapidamente do que outros. O irrigante, por exemplo, pode variar a quantidade utilizada de água, ou energia, em breve espaço de tempo, mas levará muito mais tempo para formar uma área com culturas permanentes em franca produção. Na agricultura, o problema da rigidez no uso de alguns fatores é ainda mais acentuado, por ser uma atividade regida e ditada por leis biológicas.

A grande contradição do conceito apresentado de DAP pelo fator $x$, é decorrente da inclusão da remuneração $\mathrm{F}$ dos fatores fixos. Uma visão mais apropriada, seria considerar a existência de algum custo de oportunidade para os demais fatores, onde $C$ seja igual a $\left(\Sigma P_{i} X_{i}\right)$, sendo que $i \neq x$.

Observa-se que $C$ representa a remuneração de todos os fatores com exceção de $x$. Então, poderia ser determinada a DAP*, como sendo:

$$
\mathrm{DAP} *=\mathrm{VBP}-\mathrm{C},
$$

com a condição de que $\mathrm{C} \leq \mathrm{F}$.

4.1.6. Elasticidade da demanda derivada.

A demanda de um fator pelo produtor nada mais é que uma demanda derivada (Barros, 1987). Conforme Hicks (1957), citado por Barros (1987, p.79), a elasticidade da demanda derivada pode ser determinada através de:

$$
E_{a} P_{a}=\frac{\eta \sigma+e_{b}\left(K_{a} \eta-K_{b} \sigma\right)}{e_{b}+K_{a} \sigma-K_{b} \eta}
$$

onde: $\mathrm{E}_{a} \mathrm{P}_{a}$ é a elasticidade preço da demanda derivada de $a, \sigma$ é a elasticidade de 
substituição, $\mathrm{e}_{b}$ é a elasticidade da demanda de $b$; e, $\mathrm{K}_{a}$ e $\mathrm{K}_{b}$, são as elasticidades parciais de produção dos fatores $\boldsymbol{a}$ e $\boldsymbol{b}$.

Dada a pressuposição de homogeneidade linear da função de produção e mantendo-se fixo o fator $\boldsymbol{b}$, então, $\mathrm{e}_{b}=0, \eta=\infty, \sigma=1$. Assim, a equação 38 fica igual a $\sigma /\left(\mathrm{K}_{a}-1\right)$, dado que $\sigma=1$ e o denominador é igual a elasticidade parcial de produção de a menos 1, representando o expoente da sua curva de demanda.

\subsection{O Modelo Empírico}

\subsubsection{Os dados}

O perímetro irrigado Curu-Paraipaba é dividido em dois (2) grandes setores, denominados de etapas I e II, que possuem, respectivamente, 517 e 214 irrigantes. O projeto é muito diversificado. Apenas $8,34 \%$ dos produtores assentados nas duas etapas exploram uma só cultura. Em 1994, haviam 17 linhas importantes de exploração entre culturas consorciadas e solteiras (SRH, 1995).

A Tabela 2 mostra que a área explorada em consórcio representa 15,5\% da área total, sendo que o consórcio de duas culturas é o mais freqüente, representando $87,1 \%$ da área total consorciada. 
Tabela 2 - Área cultivada por etapa segundo as formas de exploração no projeto CuruParaipaba, safra 1994/95.

\begin{tabular}{lrrr}
\hline $\begin{array}{c}\text { Forma de } \\
\text { exploração }\end{array}$ & $\begin{array}{c}\text { Etapa I } \\
\text { Areatha }\end{array}$ & $\begin{array}{c}\text { Etapa II } \\
\text { Area(ha) }\end{array}$ & $\begin{array}{c}\text { Total-Área } \\
\text { (ha) }\end{array}$ \\
\hline Consórcio-4 culturas & 4,85 & 2,15 & 7,00 \\
Consórcio-3 culturas & 25,50 & 11,80 & 37,30 \\
Consórcio-2 culturas & 276,26 & 22,95 & 299,21 \\
Culturas solteiras & $1.221,00$ & 647,36 & $1.868,36$ \\
\hline Total & $1.527,61$ & 684,26 & $2.211,87$ \\
\hline
\end{tabular}

Fonte: Cadastro dos produtores do vale do Curu.

A Tabela 3 detalha a área cultivada do conjunto de linhas de exploração condensadas na Tabela 2. Mostra também a importância relativa das linhas de exploração em termos de área cultivada, o que representa um critério para seleção daquelas que serão objeto deste estudo.

Observa-se que a área total registrada na Tabela 3 difere da área contida na Tabela 2 porque, desta, foram excluídas as seguintes informações: os consórcios de três e quatro culturas que possuem pequena relevância de área cultivada, apenas 44,3 ha. A segunda exclusão refere-se às forrageiras com aproximadamente 300 ha explorados. Elas não foram consideradas por ocuparem áreas marginais e serem destinadas quase que exclusivamente à pecuária do próprio irrigante. A terceira exclusão foi de áreas exploradas em regime de sequeiro, tais como, feijão isolado, áreas com macaxeira que de um modo geral não tem irrigação intensiva, e alguns consórcios, com área total de aproximadamente 170 ha. Finalmente, foram excluídas áreas ocupadas por culturas permanentes ainda não produzindo, totalizando 412 ha. Embora utilizem água na irrigação por aspersão convencional, não seria apropriado utilizar estas culturas num estudo de curto prazo. Grande parte da área com culturas nesta fase, está na segunda etapa, de implantação mais recente. 
Tabela 3 - Área cultivada das linhas de exploração e importância relativa por etapa do projeto Curu-Paraipaba, safra 1994/95.

\begin{tabular}{|c|c|c|c|c|c|c|}
\hline \multirow{2}{*}{$\begin{array}{l}\text { Linhas de exploração } \\
\text { Consórcio e cult. solteira }\end{array}$} & \multicolumn{2}{|c|}{ Etapa I } & \multicolumn{2}{|c|}{ Etapa II } & \multicolumn{2}{|c|}{ Total } \\
\hline & ha & $\%$ & ha & $\%$ & ha & $\%$ \\
\hline Coco + macaxeira & 11,73 & 1,33 & & & 11,73 & 0,92 \\
\hline Coco + mamão & 9,30 & 1,05 & 12,30 & 3,13 & 21,60 & 1,69 \\
\hline $\operatorname{coco}+$ feijão & 3,19 & 0,36 & & & 3,19 & 0,25 \\
\hline coco + abóbora & 7,29 & 0,83 & & & 7,29 & 0,57 \\
\hline acerola + mamão & 27,44 & 3,12 & & & 27,44 & 2,15 \\
\hline cana + feijão & 35,84 & 4,08 & 2,81 & 0,71 & 38,65 & 3,04 \\
\hline laranja + macaxeira & 8,00 & 0,91 & & & 8,00 & 0,62 \\
\hline feijão + mamão & 19,65 & 2,23 & & & 19,65 & 1,54 \\
\hline outros consórcios & 22,91 & 2,60 & 7,84 & 1,99 & 30,75 & 2,41 \\
\hline melancia & 9,15 & 1,04 & & & 9,15 & 0,71 \\
\hline mamão & 59,39 & 6,76 & 19,34 & 4,92 & 78,73 & 6,19 \\
\hline macaxeira & 25,31 & 2,88 & 12,19 & 3,10 & 37,50 & 2,95 \\
\hline feijão & 25,20 & 2,86 & 5,60 & 1,42 & 30,80 & 2,42 \\
\hline $\operatorname{coco}$ & 156,99 & 17,87 & 27,40 & 6,97 & 184,39 & 14,50 \\
\hline laranja & 33,10 & 3,76 & & & 33,10 & 2,60 \\
\hline cana-de-açúcar & 354,25 & 40,33 & 301,27 & 76,72 & 655,52 & 51,57 \\
\hline caju & 8,20 & 0,93 & & & 8,20 & 0,64 \\
\hline Acerola & 45,00 & 5,12 & & & 45,00 & 3,54 \\
\hline outras culturas solteiras & 16,36 & 1,86 & 3,92 & 0,99 & 20,28 & 1,59 \\
\hline Área Total & 878,30 & 100,00 & 392,67 & 100,00 & 1270,97 & 100,00 \\
\hline
\end{tabular}

Fonte: Cadastro dos produtores do vale do Curu.

A cultura do coco é a mais significativa em termos de área recém-implantada com $70 \%$ desta, seguida da cana-de-açúcar, com 10\%. As $20 \%$ restantes estão distribuídas em várias culturas solteiras ou exploradas em regime de consórcio.

A Tabela 3 mostra que, no âmbito global do projeto, as culturas mais importantes quanto à área cultivada são a cana-de-açúcar, ocupando $51,57 \%$ da área, o coco, ocupando $14,5 \%$, seguidos pelo mamão, $\operatorname{com} 6,2 \%$, todas exploradas 
individualmente. No conjunto, estas culturas ocupam $72,26 \%$ da área total. Na etapa I, estas culturas utilizam $65 \%$ da área, enquanto na etapa II, só a cana-de-açúcar participa com $76,72 \%$ da área total cultivada e em franca produção.

A Tabela 4 mostra o valor da produção das diversas linhas exploradas e sua importância relativa. O coco lidera as demais, participando com $32,2 \%$ do valor bruto da produção (VBP) total. Seguem-se, em ordem de importância, a cana-de-açúcar com $30,54 \%$ do VBP, e o mamão, com $11,1 \%$ do VBP. No conjunto, estas culturas, todas exploradas isoladamente, representam $73,84 \%$ do VBP total.

Foram selecionadas para este estudo as culturas da cana-de-açúcar, coco e mamão, considerando-se que, no conjunto, ocupam $72,26 \%$ da área em produção e participam com $73,84 \%$ do VBP. Esta três culturas serão objeto de estudo na etapa I por participarem em $65 \%$ da área cultivada e com 70,36\% do VBP. Procurou-se manter um certo equilíbrio do grau de importância relativa das culturas no tocante à área e VBP nas duas etapas do projeto. Isto justifica a seleção apenas da cana-de-açúcar para o estudo na etapa II, por participar com $76,72 \%$ da área e $71,77 \%$ do VBP nesta etapa do projeto. 
Tabela 4 - Valor bruto da produção das linhas de exploração e importância relativa por etapa do projeto Curu-Paraipaba, safra 1994/95.

\begin{tabular}{|c|c|c|c|c|c|c|}
\hline \multirow{2}{*}{$\begin{array}{l}\text { Linha de exploração } \\
\text { consórc./cult.solteira }\end{array}$} & \multicolumn{2}{|c|}{ Etapa I } & \multicolumn{2}{|c|}{ Etapa II } & \multicolumn{2}{|c|}{ Total } \\
\hline & $\mathrm{R} \$$ & $\%$ & R\$ & $\%$ & $\mathrm{R} \$$ & $\%$ \\
\hline coco+macaxeira & 38735,0 & 2,45 & & & 38735,0 & 1,96 \\
\hline coco+mamão & 46200,6 & 2,92 & 18289,0 & 4,67 & 64489,6 & 3,27 \\
\hline $\operatorname{coco+feijão~}$ & 10824,0 & 0,68 & & & 10824,0 & 0,54 \\
\hline coco+abóbora & 21183,0 & 1,34 & & & 21183,0 & 1,07 \\
\hline acerola+mamão & 19080,0 & 1,20 & & & 19080,0 & 0,96 \\
\hline cana +feijão & 38959,0 & 2,47 & 2403,0 & 0,61 & 41362,0 & 2,10 \\
\hline laranja+macaxeira & 23342,5 & 1,47 & & & 23342,5 & 1,18 \\
\hline feijão + mamão & 63900,0 & 4,05 & & & 63900,0 & 3,24 \\
\hline outros consórcios & 28836,0 & 1,82 & 10615,0 & 2,71 & 39451,0 & 2,00 \\
\hline melancia & 23232,0 & 1,47 & & & 23232,0 & 1,18 \\
\hline mamão & 185184,0 & 11,74 & 33510,0 & 8,56 & 218694,0 & 11,10 \\
\hline macaxeira & 15215,0 & 0,96 & 6885,0 & 1,75 & 22100,0 & 1,12 \\
\hline feijão & 21156,0 & 1,34 & 2466,0 & 0,62 & 23622,0 & 1,19 \\
\hline $\operatorname{coco}$ & 604317,0 & 38,31 & 29656,0 & 7,57 & 633973,0 & 32,20 \\
\hline laranja & 39769,0 & 2,52 & & & 39769,0 & 2,02 \\
\hline cana-de-açúcar & 320439,6 & 20,31 & 280956,0 & 71,77 & 601395,6 & 30,54 \\
\hline caju & 2908,0 & 0,18 & & & 2908,0 & 0,14 \\
\hline acerola & 48750,0 & 3,09 & & & 48750,0 & 2,47 \\
\hline outros & 25194,0 & 1,59 & 6663,0 & 1,70 & 31857,0 & 1,61 \\
\hline Total do VBP & 1577225,0 & 100,00 & 391443,0 & 100,00 & 1968668,00 & 100,00 \\
\hline
\end{tabular}

Fonte: Cadastro dos produtores do vale do Curu.

A cana-de-açúcar é explorada na etapa I por 268 produtores, com uma área média de 1,31 ha (Tabela 5). São 148 produtores que exploram a cana-de-açúcar isolada. O restante explora uma ou mais culturas, além da cana. As áreas cultivadas variam de 0,15 a 6 ha, sendo que o maior número de produtores exploram áreas de até 1 ha e exibem produtividade superior aos dos outros estratos. 
Tabela 5 - Número de produtores, área cultivada, produção e valor da produção por estrato de área da cana-de-açúcar, etapa I do projeto Curu-Paraipaba, safra $1994 / 95$.

\begin{tabular}{ccccc}
\hline $\begin{array}{c}\text { Estrato de área } \\
\text { ha }\end{array}$ & $\begin{array}{c}\text { Produtores } \\
\text { número }\end{array}$ & $\begin{array}{c}\text { Área } \\
\text { ha }\end{array}$ & $\begin{array}{c}\text { Produção } \\
\text { ton. }\end{array}$ & $\begin{array}{c}\text { Valor da } \\
\text { Produção } \\
\text { R \$ }\end{array}$ \\
\hline até 1 & 141 & 99,30 & $5.858,70$ & $105.456,60$ \\
de 1 a 2 & 112 & 209,45 & $9.418,78$ & $169.538,04$ \\
mais de 2 & 15 & 45,50 & $2.524,72$ & $45.444,96$ \\
\hline Total & 268 & 354,25 & $17.802,20$ & $320.439,60$ \\
\hline
\end{tabular}

Fonte: Cadastro dos produtores do vale do Curu.

$\mathrm{Na}$ etapa II, a cana-de-açúcar é a cultura dominante, razão de ser a única focalizada nesta etapa no presente estudo. Os 157 irrigantes que compõem o universo de produtores registrados na Tabela 6 representam $73,36 \%$ da totalidade dos assentados. $O$ estrato de área entre 1 e 2 ha é o que apresenta maior frequiência em número de produtores, área, produção e valor da produção.

Tabela 6 - Número de produtores, área cultivada, produção e valor da produção por estrato de área da cana-de-açúcar, etapa II do projeto Curu-Paraipaba, safra $1994 / 95$.

\begin{tabular}{ccccc}
\hline $\begin{array}{c}\text { Estrato de Área } \\
\text { ha }\end{array}$ & $\begin{array}{c}\text { Produtores } \\
\text { número }\end{array}$ & $\begin{array}{c}\text { Área } \\
\text { ha }\end{array}$ & $\begin{array}{c}\text { Produção } \\
\text { ton. }\end{array}$ & $\begin{array}{c}\text { Valor da Produção } \\
\text { R\$ }\end{array}$ \\
\hline até 1 & 19 & 16,60 & 819,00 & $14.742,00$ \\
de 1 a 2 & 98 & 160,45 & $7.740,70$ & $139.332,60$ \\
mais de 2 & 40 & 124,22 & $7.049,00$ & $126.882,00$ \\
\hline Total & 157 & 301,27 & $15.608,70$ & $280.956,60$ \\
\hline
\end{tabular}

Fonte: Cadastro dos produtores do vale do Curu. 
O mamão tem a menor área explorada dentre as incluídas neste estudo. É uma cultura que apresenta quase o triplo do VBP/ha em relação à cana-de-açúcar ${ }^{25}$. Mas, a possibilidade de expansão da área de cultivo do mamão é pequena, decorrente de limitações da demanda regional. Sendo um produto perecível, não existem condições tecnológicas no projeto que permitam atender aos condicionantes qualitativos exigidos pelo mercado. Os cultivos estão concentrados em áreas com até 1 ha, representando 64,6 $\%$ da área total explorada por mais de $90 \%$ dos produtores. É também o estrato que exibe o maior valor da produção, conforme a Tabela 7.

Tabela 7 - Número de produtores, área cultivada, produção e valor da produção por estrato de área do mamão, etapa I do projeto Curu-Paraipaba, safra 1994/95.

\begin{tabular}{ccccc}
\hline $\begin{array}{c}\text { Estrato de área } \\
\text { ha }\end{array}$ & $\begin{array}{c}\text { Produtores } \\
\text { número }\end{array}$ & $\begin{array}{c}\text { Área } \\
\text { ha }\end{array}$ & $\begin{array}{c}\text { Produção } \\
\mathrm{kg}\end{array}$ & $\begin{array}{c}\text { Valor da Produção } \\
\mathrm{R} \$\end{array}$ \\
\hline Até 1 & 64 & 38,37 & 944.618 & $139.150,87$ \\
de 1 a 2 & 6 & 17,27 & 227.141 & $33.460,08$ \\
mais de 2 & 1 & 3,75 & 85.351 & $12.573,05$ \\
Total & 71 & 59,39 & 1.257 .110 & $185.184,00$ \\
\hline
\end{tabular}

Fonte: Cadastro dos produtores do vale do Curu.

O coco, embora ocupando uma área que representa menos de um terço da área ocupada pela cana-de-açúcar (Tabela 8), tem maior VBP que esta. É produzido quase que exclusivamente na etapa I, em áreas que variam de 0,05 a 5,6 ha. A Tabela 8 mostra que o número de produtores, áreas cultivadas, produção e valor concentram-se no estrato de até 1 ha. A área média total explorada com coco é de 0,95 ha.

${ }^{25}$ Informação que pode ser obtida a partir das tabelas 5,6 e 7 . 
Tabela 8 - Número de produtores, área cultivada, produção e valor da produção por estrato de área do coco, etapa I do projeto Curu-Paraipaba, safra 1994/95.

\begin{tabular}{ccccc}
\hline $\begin{array}{c}\text { Estrato de área } \\
\text { ha }\end{array}$ & $\begin{array}{c}\text { Produtores } \\
\text { número }\end{array}$ & $\begin{array}{c}\text { Área } \\
\text { ha }\end{array}$ & $\begin{array}{c}\text { Produção } \\
\text { unidade }\end{array}$ & $\begin{array}{c}\text { Valor da Produção } \\
\text { R\$ }\end{array}$ \\
\hline até 1 & 137 & 90,00 & 1.670 .608 & $334.121,60$ \\
de 1 a 2 & 24 & 38,90 & 677.790 & $135.558,00$ \\
mais de 2 & 10 & 28,09 & 673.187 & $134.637,40$ \\
Total & 171 & 156,99 & 3.021 .585 & $604.317,00$ \\
\hline
\end{tabular}

Fonte: Cadastro dos produtores do vale do Curu.

\subsubsection{A amostra}

Para o cálculo do tamanho da amostra, foi selecionada a variável produtividade da terra por ser a mais relevante das disponíveis no cadastro efetuado no ano agrícola 1994/95. A técnica de amostragem adotada foi a amostra aleatória simples.

O período base considerado, como mencionado anteriormente, foi o do ano agrícola 1995/96, embora os dados tenham sido coletados no $1^{0}$ trimestre de 1997. Isto permitiu que os dados de produção se referissem sempre às áreas colhidas efetivamente no ano-base.

A amostra foi extraída do universo constituído pelos produtores que exploram as culturas do coco, mamão e cana-de-açúcar na etapa I, e cana-de-açúcar na etapa II. Apenas $10 \%$ dos irrigantes não participaram do sorteio por desenvolverem outros cultivos. Cada produtor possui um lote de terra sistematizada com praticamente o mesmo tamanho (4,03 ha), embora a área irrigada total seja distinta. Podem explorar uma, duas ou mais culturas, sejam solteiras ou em consórcio. Como o plano amostral foi feito por produto, um mesmo produtor pôde ser sorteado para responder questionários sobre culturas distintas. Isto ocorreu com $6,2 \%$ do total de produtores entrevistados. 
Esta pesquisa de campo teve o objetivo de complementar o cadastro já mencionado, que não contemplava todas as informações necessárias ao estudo. O tamanho da amostra $\mathbf{n}$ foi determinado através de:

$$
n=\frac{Z^{2} \sigma^{2} N}{d^{2}(N-1)+Z^{2} \sigma^{2}}
$$

onde: $\mathbf{Z}$ é abcissa da curva normal padrão, fixado um determinado nível de confiança; $\sigma$ é o desvio padrão da população; $N$ é o tamanho da população; e, d é o erro amostral expresso na unidade da variável. O erro amostral foi arbitrado em 10\% da média do rendimento observado na população.

A Tabela 9 mostra os dados utilizados na eq. 38 para o cálculo do tamanho da amostra. Os produtores foram selecionados aleatoriamente através de sorteio.

Tabela 9 - Parâmetros utilizados para o cálculo do tamanho da amostra para as culturas de cana-de-açúcar, coco e mamão na etapa I e cana-de-açúcar na etapa II.

\begin{tabular}{crrrrr}
\hline Parâmetros & \multicolumn{3}{c}{ Etapa I } & & Etapa II \\
\cline { 2 - 3 } & cana-de-açúcar & coco & mamão & & cana-de-açúcar \\
\hline$Z^{*}$ & 1,645 & 1,645 & 1,645 & & 1,645 \\
$\sigma$ & 17,89 & 6,7 & 11,5 & & 17,5 \\
$\mathrm{~N}$ & 268 & 171 & 71 & & 157 \\
$\mathrm{~d}$ & 5,02 & 1,8 & 2,419 & & 5,03 \\
\hline $\mathbf{n}$ & $\mathbf{3 0}$ & $\mathbf{3 1}$ & $\mathbf{3 3}$ & $\mathbf{2 7}$ \\
\hline
\end{tabular}

* nível de confiança igual a $90 \%$. 


\subsubsection{O perfil da amostra.}

Nesta seção é feita uma descrição de algumas características predominantes na amostra, por produto estudado, com ênfase nos seus aspectos qualitativos, embora quando necessário, se recorra à informações mensuráveis.

\section{1) Produtores de coco:}

A principal observação feita por esses produtores por ocasião das entrevistas, foi a de como resolver o dilema entre comercializar a produção através da cooperativa dos irrigantes, pagando uma taxa de $18 \%$ sobre o VBP, ou comercializar "por fora", sem a incidência desse ônus.

A cooperativa coloca a sua estrutura a serviço do produtor de coco exclusivamente na área de comercialização. Efetua pesquisas de preços do coco, estabelece contratos de compra antecipada da produção, organiza e financia a colheita, acondicionamento e o transporte interno do produto e negocia as despesas com o frete. Assim, $30 \%$ dos produtores da amostra afirmaram vender sua produção diretamente à compradores avulsos, por considerarem esse procedimento mais vantajoso do ponto de vista econômico.

A idade média do chefe da família produtora de coco é de 51 anos, semelhante a observada dos demais produtores entrevistados nas outras culturas. Sua escolaridade é baixa, com média de 2,5 anos de estudo, o que também é verificado em termos gerais no projeto. O serviço de extensão rural atendeu $30 \%$ dos produtores da amostra. Deve-se destacar que alguns produtores de alta escolaridade, passaram a dar maior atenção à cultura em épocas recentes, obtendo rendimentos muito superiores à média do projeto. A família do irrigante tem em média 6 membros e os dados da amostra indicam que $13 \%$ dos entrevistados possuem 10 ou mais dependentes.

Cada produtor, segundo a amostra, irrigou em média 1 ha com cerca de 195 coqueiros, absorvendo em torno de 80 diárias ao longo do ano agrícola. A quantidade 
usada de água pelo produtor que explora a área média foi de $9.000 \mathrm{~m}^{3} / \mathrm{ha}$ ano As áreas irrigadas apresentam grande variabilidade, com produtores explorando 0,14 ha até o limite máximo de 2,94 ha.

Os produtores obtiveram em média um VBP/ha de $\mathrm{R} \$ 4.234,00$, o maior dentre as culturas estudadas. Como ilustração e em virtude da amostra não contemplar dados de custos totais de produção, recorreu-se aos estudos do DNOCS (1995) sobre o assunto, que apresenta um índice de lucratividade ${ }^{26}$ do coco em 0,24 , em outubro de 1995.

A cultura do coco foi introduzida sistematicamente no projeto, no início da década de 90. Assim, contou com o apoio da EMATERCE e EMBRAPA, e com o efeito-demonstração de alguns produtores inovadores isolados, que haviam introduzido a cultura há mais tempo. Os dados da amostra refletem isto, onde $10 \%$ dos entrevistados exploravam coqueirais com 12 anos, enquanto que a média amostral de idade das plantas é de 5 anos.

\section{2) Produtores de mamão}

Nas observações registradas nos 33 questionários preenchidos com estes produtores, destacam-se dois aspectos relevantes. O mais comum é a falta de crédito destinado principalmente aos tratos fitossanitários. $O$ ataque de nematóides é considerado pelos produtores o principal fator limitante ao incremento da produtividade. Esta é esperada pelo DNOCS em seus projetos de irrigação, em 45 ton/ha, enquanto os dados amostrais indicam um rendimento médio de 20 ton/ha.

A maneira encontrada pelos produtores para enfrentar o problema de nematóides no mamoeiro foi a utilização de mais água na irrigação do que a requerida

\footnotetext{
${ }^{26}$ O DNOCS através do GAP (Grupo de Apoio à Produção) da Diretoria de Irrigação, publica o "relatório trimestral sobre custos e receitas das principais culturas irrigadas nos perímetros irrigados. Seu conceito de Índice de Lucratividade - IL - é igual ao (valor da produção - total geral de custos) / total geral de custos. Em out./1995, este índice foi de 0,24 para o coco e 2,35 para o mamão. A cana-de-açúcar teve IL negativo e igual a $-0,4$.
} 
pelas plantas. Seis produtores admitiram utilizar esta prática, sobre a qual não se conhece nenhuma referência na literatura ou comprovação científica. Acredita-se que mais produtores adotam esse procedimento, considerando-se que 9 (nove) observações ou 27 \% da amostra, evidenciaram um consumo dágua/ha superior ao limite máximo estabelecido de $18 \mathrm{mil} \mathrm{m}^{3} / \mathrm{h}$. Por ser a cultura que utilizou mais água/ha $\left(15.175 \mathrm{~m}^{3} / \mathrm{ha}\right)$ o produtor de mamão obteve menos da metade do $\mathrm{VBP} / \mathrm{mil}^{3}$ de água, quando se compara com aqueles que exploram o coco.

O segundo aspecto, citado pelos produtores, foi a falta de agroindústria na região e/ou falta de oportunidades de venda do produto fora dela, restringindo a expansão da cultura. Os dados amostrais indicam áreas médias por produtor diminutas ( 0,73 ha), tendo a maior área irrigada 1,7 ha e a menor, 0,15 ha.

O VBP/ha médio atinge R\$2.950,00 e, conforme DNOCS (1995), o mamão foi a cultura que apresentou o mais alto índice de lucratividade nos seus projetos de irrigação em outubro de 1995. Pelos menos quanto aos dados amostrais aqui apresentados, é pouco provável isto acontecer no projeto Curu-Paraipaba. Além de exibir menor VBP/ha do que o coco, a cultura do mamão é também a que absorve mais mãode-obra. Isto, talvez seja um incentivo para as famílias de maior tamanho, o que é ratificado pelos dados amostrais (em média 7 membros). Cada produtor gasta em torno de $R \$ 430,00$ com insumos básicos, significando quase o dobro do dispêndio com esses fatores nas demais culturas. Ressalte-se que a área explorada com o mamão é, em média inferior às das demais culturas.

Os dados da amostra demonstram ainda que os produtores de mamão são mais idosos (52 anos), com escolaridade média de 3,2 anos de estudos; cerca de $10 \%$ são analfabetos. Metade dos produtores entrevistados afirmaram ter recebido assistência do serviço de extensão rural. 


\section{3) Produtores de cana-de-acúcar}

Na fase de implantação do projeto Curu-Paraipaba, em 1973, as principais culturas exploradas eram, tomate, laranja, cebola, amendoim, abacate e maracujá. Com a criação do PROALCOOL, o governo federal passou a incentivar em seus projetos de irrigação pública a cana-de-açúcar, substituindo aquelas culturas implantadas inicialmente. O mesmo programa viabilizou a implantação de agroindústrias para a produção de álcool. No vale do Curu, foi instalada a usina AGROVALE, que passou a contar com a garantia da oferta de matéria-prima.

No ano agrícola de 1995/96 havia uma população de 424 produtores de canade-açúcar com uma área irrigada de 655,5 ha. Nesta pesquisa, foram sorteados 57 produtores de cana para compor a amostra, sendo 30 na etapa I e 27 na etapa II.

Estimulados a responder qual o maior problema enfrentado na exploração da cana, $76 \%$ dos produtores entrevistados na etapa I responderam que foi a severa escassez dágua para irrigação. Doze produtores $(40 \%)$, afirmaram que estariam dispostos a pagar mais pela água (sem indicar o valor) para tê-la no volume e tempo desejados. A quantidade utilizada dágua/ha $\left(7.000 \mathrm{~m}^{3}\right)$, foi a mais baixa dentre as culturas estudadas.

Na etapa I, $94 \%$ dos produtores vendiam toda a produção para a usina AGROVALE, enquanto na etapa II, esse percentual caiu para $71 \%$. Estes, não enfrentam maiores problemas de escassez dágua. Mais objetivamente, na etapa II, de implantação recente, o sistema de suprimento e de distribuição é mais novo e melhor conservado, com menor número de irrigantes e, portanto, menos competitivo. Neste caso, o consumo dágua/ha foi de $13 \mathrm{mil} \mathrm{m}^{3}$, quase o dobro do consumo na etapa I. O produtor médio de cana-de-açúcar da etapa II entende que, enquanto estiver vinculado à usina AGROVALE, dada a falta de crédito formal, dificilmente terá progresso econômico. Mais da metade dos entrevistados manifestou o desejo de substituição da cana-de-açúcar por outras atividades mais rentáveis, especialmente o coco. E só não o fizeram por falta 
de crédito. Ressalte-se que os produtores da etapa I aparentemente não apresentam esta pretensão.

As áreas médias cultivadas com cana, são quase idênticas nas duas etapas, em torno de 1,6 ha. As áreas sob cultivo variam entre 0,3 e 4 ha (área total do lote).

A cana-de-açúcar apresentou o mais baixo VBP/ha dentre as culturas analisadas, em torno de R\$ 790,00. Em outubro/95, o DNOCS (1995) afirmou que na média dos projetos de irrigação pública, a cana-de-açúcar apresentou índices de lucratividade negativos, adiantando ainda que isto vinha acontecendo desde 1992.

Nos aspectos sócioeconômicos, os dados amostrais indicam que os produtores de cana-de-açúcar nas etapas I e II situam-se em posições extremas, quando comparados com os demais produtores. Assim, os produtores da etapa II apresentam em média a maior escolaridade (3,6 anos de estudo), embora $11 \%$ destes sejam analfabetos e $15 \%$ detenham de 11 a 15 anos de estudo formal. Na etapa I, a média de escolaridade é a mais baixa (1,3 ano de estudo) e nenhum dos entrevistados admitiu ser analfabeto. $\mathrm{Na}$ etapa II a idade média (44 anos), o tamanho da família é o menor. Os produtores da etapa I têm em média 49 anos, com 5 dependentes. A assistência técnica era feita eventualmente pela EMATERCE e/ou pela usina, neste caso, para aqueles com quem mantinha contrato de aquisição da cana, em intervalos irregulares

4.24. Definição dos elementos de análise

Para estimar o preço e quantidade dágua destinada à irrigação, é recomendável dispor-se de um esquema analítico que ofereça uma sequêencia lógica do objetivo de estudo. Os itens deste esquema, que devem ser clarificados, são: 


\subsubsection{Categoria de uso}

A forma de utilização do recurso hídrico é do tipo consuntivo. Implica o consumo de parte ou totalidade da água, de modo a promover alteração no atributo quantidade por unidade de tempo. Outros estudos podem enfocar perdas na qualidade, tais como salinização, contaminação com metais pesados ou demais formas de alterações qualitativas. Isto significa que a água, depois de utilizada, não tem os mesmos atributos qualitativos de antes. A recuperação de sua qualidade implica na ocorrência de custos para que o recurso passe a ter a mesma utilidade de antes. Da mesma forma, redução da quantidade disponível, significa que utilidades e lucros serão renunciados.

Os métodos envolvidos neste uso, são os de interceptação, armazenamento no reservatório, derivação e distribuição aos usuários. Usos não consuntivos da água deixam seus atributos inalterados, como a pesca, por exemplo. Este tipo de uso não é relevante ao presente estudo.

4.2.4.2. Fonte de suprimento

A destinação consuntiva é constituída pelo uso de água nos lares domésticos, na agricultura e na indústria. Estimando as funções de demanda para cada um destes setores, pode-se obter a demanda total para uma fonte particular. A combinação da demanda com a oferta existente define preços e quantidades dágua para cada setor.

Neste estudo, a fonte de suprimento são os açudes General Sampaio, Pentecoste e Caxitoré que distribuem água para cidades do Vale e os projetos de irrigação. Praticamente, não há indústrias na área.

No início do segundo semestre de cada ano, é feita uma estimativa das disponibilidades de água armazenada. Com base no consumo histórico e indicações de consumo feitas por alguns representantes dos setores, são determinadas as dotações de 
água para o período seguinte. Os dados necessários ao balanço hídrico (entradas, saídas e perdas dágua por evaporação) são medidos com freqüência diária.

\subsubsection{Unidade setorial consumidora}

A irrigação constitui-se no fornecimento de água às culturas agrícolas na quantidade, qualidade e tempo, de forma a assegurar as respectivas produções. Existem várias técnicas empregadas, dentre as quais, por sulcos, aspersão, gotejamento, inundação e pivot central, visando a atender às condições de solo, da cultura, tudo dentro do nível tecnológico prevalecente ${ }^{27}$.

A irrigação possibilita garantir o suprimento constante de água, mesmo nas épocas de seca, fato comum no semi-árido, gerando impactos positivos, tanto nos aspectos econômicos como sociais. No primeiro, garante a possibilidade de obtenção de mais de uma safra por ano, aumentando a produtividade dos fatores de produção, que, de outra forma. ficariam ociosos nos períodos secos. Conseqüentemente, ela pode aumentar a renda do produtor, melhorar a qualidade do produto, estimular o avanço tecnológico e viabilizar a exploração de culturas de maior valor.

Do ponto de vista social, a irrigação amplia as oportunidades de emprego e reduz as suas oscilações ao longo do ano. É uma medida que contribui para a fixação do homem no meio rural.

\subsubsection{Forma funcional}

Uma idéia básica que ganhou corpo e serviu para o desenvolvimento da teoria marginalista remonta a 1838, quando Cournot afirmava: "os incrementos de grandezas

\footnotetext{
${ }^{27}$ No projeto em estudo, o método de irrigação é por aspersão convencional.
} 
econômicas são mais importantes para reflexões econômicas do que as grandezas totais" (Schneider, 1968, p.146). Mas foi Liebig (1855), citado por Thompson (1973, p.149), quem fez a primeira aplicação empírica do conceito emitido por Cournot, descrevendo a produção agrícola em resposta ao uso de fertilizantes. Neste trabalho, Thompson (1973, p.149) afirma que Liebig considerava as relações físicas de produção pré-determinadas, sem considerar a possibilidade de substituição entre fatores, ou seja, a lei de proporções variáveis e, portanto, a influência dos preços relativos.

Em 1909, Mitscherlich apresentou um trabalho que continha a idéia de retornos decrescentes ${ }^{28}$ a um fator variável. Seu modelo, desde então, tem tido grande emprego na experimentação agrícola, principalmente na determinação de dosagens ótimas de fertilizantes. Nesta mesma linha, destacam-se, a partir da década de 20, os trabalhos de Spillman, cuja maior preocupação era a aplicação empírica dos conceitos estabelecidos quanto à lei dos rendimentos decrescentes (Debertin, 1986, p.184).

Muito tem sido feito, desde então, com o intuito de identificar formas algébricas que sejam teoricamente consistentes e empiricamente úteis para descrever e identificar relações entre insumos e produtos. Grande contribuição neste sentido foi dada por de Janvry (1972), que desenvolveu uma forma geral da função de produção tipo potência a "Generalized Power Production Function" (GPPF), que pode ser representada por:

$$
Y=X_{1}^{g\left(K_{i}\right)} X_{2}^{b\left(K_{j}\right)} e^{f\left(X_{i}\right)}{ }_{u},
$$

onde $\mathrm{g}$ é uma função de $\mathrm{n}$ fatores $\mathrm{K}_{\mathrm{i}}$, que representam variáveis sócioeconômicas tais como, anos de estudo, idade do produtor, números de membros da família etc; b é uma função de $m$ fatores $K_{j}$, que representam variáveis tecnológicas, tais como, intensidade de uso do capital, do trabalho, da água, espaçamento etc; $f$ é uma função de $p$ fatores $X_{i}$, que representam variáveis ordinárias independentes, tais como trabalho e capital, cujas quantidades são representadas na eq. (39) por $\mathrm{X}_{1}$ e $\mathrm{X}_{2}$; u é o erro aleatório.

28 As formas e propriedades desta função estão descritas em Beattie \& Taylor (1989, p. 71). 
Os casos especiais que podem ser descritos pela função (39), são:

1) Tipo Cobb-Douglas:

Se $f=0 ; g=\alpha_{1}$ e $b=\alpha_{2}$, a função (39) fica:

$$
Y=A X_{1}^{\alpha 1} X_{2}^{\alpha 2} u,
$$

onde:

$Y=$ Variável dependente

$A=$ Constante

$\alpha_{1}$ e $\alpha_{2}=$ parâmetros da função;

$X_{1}$ e $X_{2}=$ variáveis independentes.

$u=$ erro aleatório.

Este modelo foi utilizado originalmente em 1928 em pesquisa empírica relacionando produtividade do capital e do trabalho com o produto americano.

As principais características deste modelo são:

a) os expoentes $\alpha_{i}$ representam as elasticidades parciais de produção, que são constantes e independentes dos valores atribuídos às variáveis $X_{1}, X_{2}$ e $Y$;

b) os rendimentos de escala são representados pela soma dos expoentes;

c) o valor do produto marginal de um fator é dado pela multiplicação do valor do seu produto médio pelo coeficiente de elasticidade;

d) as curvas de isoproduto são assintóticas aos eixos;

e) a taxa marginal de substituição de $X_{1}$ por $X_{2}$ é dada pela razão entre as respectivas produtividades marginais; $\mathrm{e}$,

f) a combinação ótima dos fatores produtivos mantém uma proporção constante sendo independente do nível de produção. 
A função Cobb-Douglas tem tido larga aplicação em estudos econométricos, com as vantagens de: a) expressar na sua forma logarítmica um modelo linear, o que facilita a determinação dos seus coeficientes; b) as elasticidades parciais de produção serem independentes das quantidades de $\mathrm{Y}$ e de $\mathrm{X}$, permitindo a comparação entre si; c) sendo uma função homogênea, a natureza dos rendimentos à escala pode ser determinada pela soma dos coeficientes de regressão; d) a multiplicação dos coeficientes de elasticidades pela produtividade média do respectivo fator fornece diretamente a produtividade do fator; e, e) permitir maior número do grau de liberdade dos testes estatísticos pelo pequeno número de parâmetros a serem estimados, em relação a outros modelos.

O modelo Cobb-Douglas, no entanto, apresenta algumas limitações, tais como: a) não permitir explicar os diferentes estágios de produção, pelo fato de as elasticidades de produção parcial e total serem constantes; b) as isoquantas são assintóticas em relação aos eixos, significando que os fatores podem ser combinados de forma ilimitada. Isto pode não ser verdade, especialmente na agricultura pois, a partir de certo ponto, a produtividade marginal dos fatores é nula, podendo até ser negativa; e, c) a função mostra que a proporção ótima entre dois fatores é constante, porque as isoclinas são retas que passam pela origem.

Estas restrições do modelo Cobb-Douglas fizeram com que os economistas da década de 50 procurassem explicitar um modelo matemático da função de produção neoclássica com os tradicionais três estágios de produção. A proposta original neste sentido foi desenvolvida por Halter et al. (1957), que introduziram modificações na versão Cobb-Douglas. Surgiu o modelo transcendental, que é mais versátil que a CobbDouglas embora seja mais difícil de manipulação analítica. Pode exibir elasticidade não constante, ou seja, retornos marginais crescentes, decrescentes ou constantes.

\section{2) Tipo Transcendental:}

A função transcendental pode ser derivada da função (39) se: $g=\alpha_{1} ; b=\alpha_{2} ;$ e, $f\left(X_{i}\right)=\beta_{1} X_{1}+\beta_{2} X_{2} ; \mathrm{u}=$ erro aleatório, onde: 


$$
Y=A X_{1}^{\alpha 1} e^{\beta 1 X 1} X_{2}^{\alpha 2} e^{\beta 2 X 2} u
$$

Para apresentar os 3 estágios de produção, os parâmetros devem atender às seguintes condições: $A>0, \alpha_{1}, \alpha_{2}>1$ e $\beta_{1}, \beta_{2}<0$.

O produto marginal de $X_{1}$ pode ser dado por:

$$
\begin{aligned}
\alpha Y / \alpha X_{1} & =A \alpha_{1} X_{2}^{\alpha 1-1} e^{\beta 1 X 1} X_{2}^{\alpha 2} e^{\beta 2 X_{2}}+A \beta_{1} X_{1}^{\alpha 1} e^{\beta 1 X 1} X_{2}^{\alpha 2} e \beta_{2} X_{2} \\
& =A X^{\alpha 1} e^{\beta 1 X 1} X_{2}^{\alpha 2} e^{\beta 2 X_{2}}\left(\alpha_{1} X_{1}^{-1}+\beta_{1}\right), \\
& =Y\left(\alpha_{1} X_{1}^{-1}+\beta_{1}\right),
\end{aligned}
$$

onde, $\partial Y / \partial X_{1}$ representa o produto marginal de $X_{1}$.

Para saber se o produto marginal de $X_{1}$ cresce, decresce ou permanece constante quando $X_{2}$ varia, basta saber os valores da derivada parcial de $\partial Y / \partial X_{1}$ com respeito a $X_{2}$ $\left(\mathrm{F}_{12}\right)$. Valores de $X_{1}$ e de $X_{2}$ que fazem com que $F_{12}$ seja igual a zero mostram que estes fatores são independentes. Quando $F_{12}$ for positivo, indica complementaridade entre fatores; quando negativo, mostra que estes são substitutos.

Para estimar os coeficientes $\alpha_{1}, \alpha_{2}, \beta_{1}$ e $\beta_{2}$ pode-se tomar o logaritmo da eq. (41) transformando-a em:

$$
\ln Y=\ln A+\alpha_{1} \ln X_{1}+\alpha_{2} \ln X_{2}+\beta_{1} X_{1}+\beta_{2} X_{2}+\ln u
$$

A função é linear nos parâmetros e a estimativa pode ser feita pelo método dos mínimos quadrados ordinários.

Uma limitação do modelo transcendental é que os fatores $X_{1}$ e $X_{2}$ são 
independentes na produção, o que pode não ser uma boa descrição da realidade. A elasticidade parcial da produção de $\mathrm{X}_{1}$, é dada por:

$$
E_{i}=\alpha_{1}+\beta_{1} X_{1}
$$

e significa que a variação na produção em resposta a variação de $X_{1}$ não depende de outras variáveis, que não seja somente $\mathrm{X}_{1}$.

No mundo real, se os fatores são complementares, por exemplo, o emprego de maiores quantidades de $X_{1}$ deve significar necessidade de maiores quantidades de $X_{2}$. Então, eles podem não ser independentes.

Neste aspecto, a forma quadrática não apresenta esta limitação, conforme pode ser observado pelo seguinte modelo:

$$
Y=a_{1} X_{1}+a_{2} X_{2}+b_{1} X_{1}^{2}+b_{2} X_{2}^{2}+b_{3} X_{1} X_{2}
$$

Verifica-se que, se $b_{3}>0$ (coeficiente do termo de interação), os fatores serão sempre complementares, ou seja, a variação de $\mathrm{Y}$ decorrente de uma variação de $\mathrm{X}_{1}$, também, dependerá de $X_{2}$. Se $b_{3}<0$, significa que os fatores são substitutos. Uma estimativa de b não significativa, indica inexistência de interação entre os fatores.

O tipo quadrático descrito em (47), no entanto, possui sérias limitações na sua aplicação no presente estudo. As interações e termos quadráticos podem agravar os problemas de multicolinearidade, freqüentemente observados nas estimativas dos parâmetros de função de produção tradicionais, principalmente quando se refere a uma função que expressa produção total ao invés de um modelo de produtividade. Os problemas destas estimativas podem se tornar ainda mais sérios, dada a redução do grau de liberdade quando se trata de pequenas amostras, como é o presente caso. 


\section{3) Tipo CES}

Nas décadas de 60 e 70, segundo Debertin (1986), as pesquisas em economia da produção foram mais direcionadas para os aspectos de substitubilidade entre os fatores de produção. As formas funcionais não teriam necessariamente que explicitar os três estágios preconizados pelo modelo neoclássico. O maior interesse era conhecer as elasticidades de substituição entre fatores de produção. A primeira contribuição importante nesta nova linha de abordagem econômica partiu de Arrow et al. (1961). Os autores conceberam um modelo numa tentativa de generalização da função tipo CobbDouglas, conhecido como "constant elasticity of substuition" ou CES. Esta função é dada por:

$$
Y=A\left[\lambda X_{1}^{-\alpha}+(1-\lambda) X_{2}^{-\alpha}\right]^{-v / \alpha}
$$

onde $\mathrm{Y}, \mathrm{X}_{1}$ e $\mathrm{X}_{2}$ tem o mesmo significado que na função Cobb-Douglas e $\mathrm{A} \lambda, \alpha, v$ são parâmetros a ser estimados.

A elasticidade de substituição $\left(E_{s}\right)$, é constante e dada por (Beattie \& Taylor, 1989):

$$
E_{s}=\frac{1}{1+\alpha}
$$

Sendo $E_{s}$ um número positivo, obrigatoriamente $\alpha>-1$. Quando $\alpha$ tende para menos um, $E_{\mathrm{s}}$ tende para infinito, significando substituição perfeita entre os fatores. Quando $\alpha$ tende para o infinito, a eq.(48) mostra que não existe substituição entre os fatores. Quando $\alpha=0$, tem-se $E_{\mathrm{s}}=1$ e a função CES transforma-se numa Cobb-Douglas (Barbosa, 1985 p.236):

$$
Y=A X_{1}^{v \lambda} X_{2}^{v(1-\lambda)}
$$


O parâmetro $v$ significa retornos de escala, pois quando $X_{1}$ e $X_{2}$ aumentam numa mesma proporção $K$, o produto $Y$ aumenta em $K^{V}$. A função CES é homogênea de grau $v$. Então se $v$ for $>,=$ ou $<$ do que 1 , significa que os retornos à escala serão respectivamente crescentes, constantes e decrescentes.

Uma vantagem da função CES sobre a Cobb-Douglas é que sua forma geral pode descrever uma gama de possibilidades de substituição, cada uma correspondendo a uma isoquanta em particular, quando muda a elasticidade de substituição. Esta pode ser qualquer número entre zero e infinito. A equação (48) mostra, no entanto, que dado um conjunto de parâmetros, $E_{\mathrm{s}}$ é a mesma em qualquer ponto da isoquanta. Mesmo aumentando o número de fatores na função de produção, $E_{\mathrm{s}}$ continua dependendo apenas de $\alpha$. Segundo McFadden (1963) citado por Debertin (1986, p.184), esta característica da CES é altamente restritiva para seu uso, já que a grande maioria dos estudos empíricos envolve mais de dois fatores. Além disso, a manipulação algébrica da CES não é simples. Por não ser linear nos seus parâmetros, o método de regressão linear múltipla não pode ser diretamente aplicado para as estimativas dos parâmetros. Existem um conjunto de técnicas empregadas nestas estimativas, sempre com base em pressupostos ou aproximações, como a de Kmenta ou transformação de Box-Cox (Barbosa, 1985 p.238). O próprio trabalho original de Arrow et al. (1959) partiu do rígido pressuposto de que os retomos de escala seriam constantes para determinar elasticidades de substituição.

\section{4) Tipo Translog}

AS restrições presentes na CES para determinar elasticidades de substituição só foram em parte resolvidas na década de 70 , com o surgimento da função do tipo Translog ${ }^{29}$. Segundo Debertin (1982), esta foi considerada uma grande contribuição à teoria da produção. A especificação da Translog é dada por (Debertin, 1982 p.207):

\footnotetext{
29 A grande preocupação com substitubilidade de fatores parece estar relacionada com a crise mundial de petróleo que eclodiu na época.
} 


$$
\ln Y=\ln \alpha+\beta_{1} \ln X_{1}+\beta_{2} \ln X_{2}+\frac{1}{2} \lambda \ln X_{1} \ln X_{2}+\ln u
$$

que na forma antilog, pode ser descrita por:

$$
Y=\alpha X_{1}^{\beta 1} X_{2}^{\beta 2} e^{(\lambda / 2)\left[\ln X_{1} \mid\left[\ln X_{2}\right]\right.} \cdot u
$$

Pode ser visto que a translog é um membro da família de (39). Difere da equação transcendental (41) pelo fato do parâmetro $\lambda$ ser usualmente positivo. A inclinação das isoquantas da translog vai depender do parâmetro $\lambda$ que, se for igual a zero, transforma a translog na Cobb-Douglas tradicional.

Christensen et al. (1973) incluem termos quadráticos na forma logarítmica da eq. (51), que fica:

$\ln Y=\ln \alpha+\beta_{1} \ln X_{1}+\beta_{2} \ln X_{2}+\frac{1}{2} \lambda \ln X_{1} \ln X_{2}+\frac{1}{2} \theta_{1}\left(\ln X_{1}\right)^{2}+\frac{1}{2} \theta_{2}\left(\ln X_{2}\right)^{2}+\ln u .(52)$

A função Cobb-Douglas é a condição de primeira ordem da série de Taylor em $\operatorname{Ln} Y$, com $\operatorname{Ln} X_{1}$ e Ln $X_{2}$. A translog é a expansão de segunda ordem dos mesmos termos (Debertin, 1982 p.210).

O tipo translog apresenta algumas vantagens sobre os modelos apresentados até aqui. Pode exibir elasticidades de substituição diferentes para cada par de insumos. Como já visto, a Cobb-Douglas e a CES apresentam estas elasticidades restritas à unidade ou a dado valor constante para cada par de fatores. A função de produção translog também contempla várias interações nas equações estimadas, linearizadas em logaritmos. Esta é também uma grande vantagem, pois são inúmeros os fatores que interferem no processo produtivo, seja de forma direta ou indireta.

Isto significa que o modelo translog reduz o risco de exclusão de variáveis 
relevantes e, conseqüentemente, de estimativas de coeficientes viesados das variáveis incluídas no modelo por contemplar grandes alternativas de interações. O problema é que isto leva a uma redução dos graus de liberdade, em razão do pequeno número de observações por culturas selecionadas para este estudo.

As variáveis terra, trabalho, capital na forma de insumos, capital na forma de equipamentos de irrigação, e água, devem ser incluídas no modelo. São fundamentais ao processo de produção em áreas irrigadas, o que significa a estimativa de grande número de parâmetros para cada cultura. Para se ter uma idéia, com cinco variáveis, o modelo requer 21 parâmetros. Isto sem considerar variáveis de alta importância no processo produtivo, como, por exemplo, assistência técnica e variáveis sócioeconômicas e/ou tecnológicas.

Com um número médio de 30 observações por cultura, a solução seria utilizar técnicas que permitissem agregar todas as culturas para ampliar os graus de liberdades. Mas, como um dos objetivos deste trabalho é conhecer o grau de eficiência no uso dos recursos por cultura específica, a forma funcional do tipo translog, não foi utilizada

5) Tipo Cobb-Douglas com retornos à escala variáveis.

Se, na eq. (39), $X_{1}$ e $X_{2}$ são fatores de produção, g é uma função de $n$ fatores $K_{i}$, que representam variáveis sócioeconômicas tais como, anos de estudo, idade do produtor, números de membros da família etc; $b$ é uma função de $m$ fatores $K_{j}$, que representam variáveis tecnológicas, tais como, intensidade de uso do capital, do trabalho, da água, espaçamento etc; f é igual a zero; u é o erro aleatório, então a eq. (53) pode ficar assim:

$$
Y=X_{1}^{g\left(K_{i}\right)} X_{2}^{b\left(K_{j}\right)} u
$$

O modelo foi desenvolvido por Ulveling \& Fletcher (1970) e trata-se de uma modificação da função Cobb-Douglas. Verifica-se que a forma geral descrita em (39) por de Janvry (1972) pode ser adaptada a equação (53). 
Várias pressuposições podem ser feitas em relação aos K's. Pode-se supor que várias variáveis $K$ influenciam um $\beta$ em particular, ou que diferentes variáveis $K$ influenciam cada elasticidade $\beta$ separadamente. É um modelo flexível, que possibilita testar a variabilidade de escala,

Uma limitação citada por Almeida (1972) é a inexistência de fundamento teórico sobre a forma algébrica das variáveis que se pressupõe como capazes de influenciar as elasticidade de produção. Camargo (1974) afirma que isto é compensado pela sensibilidade às variações da organização técnica de produção e pelas respostas ao uso dos fatores ao longo das diversas fases do processo.

Para identificar as interações que podem influenciar as elasticidades, deve-se partir da observação empírica. A função $g\left(K_{i}\right)$ da equação (53), pode assumir a forma linear, quadrática ou cúbica, ou seja:

$$
\begin{gathered}
g\left(K_{i}\right)=b_{1}+b_{2} K_{i} \\
g\left(K_{i}\right)=b_{1}+b_{2} K_{i}+b_{3} K_{i}^{2} \\
g\left(K_{i}\right)=b_{1}+b_{2} K_{i}+b_{3} K_{i}^{2}+b_{4} K_{i}^{3}
\end{gathered}
$$

Como nem sempre a influência e a forma funcional de $g\left(\mathrm{~K}_{\mathrm{i}}\right)$ é conhecida a priori, o critério utilizado para identificar estas opções pode feito a partir dos resultados de testes estatísticos. O mesmo raciocínio se aplica com relação a b $\left(K_{j}\right)$ da eq. (53).

As desvantagens são que o modelo não admite que qualquer fator que entre no ajustamento da equação seja igual a zero, as isoquantas são assintóticas aos eixos coordenados e as isoclinas são retas que passam pela origem, sugerindo que a combinação ótima dos fatores seja constante. 


\subsubsection{Ajustamento das funções (Modelo Ulveling-Fletcher)}

Nos últimos anos grandes esforços tem sido feitos para desenvolver formas de função de produção que permitam estimativas de elasticidades de substituição entre fatores. Mas os modelos aplicados a estas elasticidades relaxam outras importantes relações entre insumos e produtos (Ulveling \& Fletcher, 1970, p.322). Primeiro porque a produção pode ser obtida por diferentes técnicas. Alguns produtores utilizam métodos de cultivo trabalho-intensivo, outros, capital-intensivo, usam mais ou menos água por unidade de área ou por planta, distintos espaçamentos etc.

Cada produtor tem uma peculiar condição social (grau de instrução, idade etc) e todas estas diferenças influem sobre os níveis de produção destes. Educação ou idade que se traduz em experiência do produtor podem ser fatores que influenciam positivamente o uso e manejo da água. As elasticidades parciais de produção, os retornos de escala e o valor do produto marginal podem ser dependentes destas técnicas e atributos. São inúmeros os fatores que afetam a produção e, por hipótese, acredita-se que tecnologia e condição social podem influenciar a produção de forma indireta.

A análise do impacto da tecnologia e de algumas destas condições sobre a relação entre o uso da água e os demais fatores sobre a produção é de grande importância para projetos de irrigação.

Os critérios considerados para inclusão de variáveis nos modelos, foram os aspectos agronômicos, sociais e econômicos.

A influência das variáveis que afetam indiretamente a produção através da medida de seus impactos sobre as elasticidades parciais, são de naturezas diversas, ou seja, muito distinta para cada cultura e cada variável. Daí a importância da utilização de um modelo que considere as especificidades de cada cultura.

Em virtude das considerações feitas até aqui sobre os distintos modelos apresentados, utilizou-se o modelo (53) descrito há pouco. 
As variáveis dependentes $Y_{i}$, onde $i=(1,2,3$ e 4) representam respectivamente a produção total de coco expressa em mil unidades, e as produções totais de mamão e de cana-de-açúcar na etapas I e II, expressas em toneladas, todas da safra 1995/96.

O modelo genérico pode ser apresentado como:

$$
Y=A \prod_{i=1}^{n} X_{i}^{\beta_{i}\left(z_{j}\right)} u \quad \operatorname{com} j=1, \ldots \ldots, r
$$

onde: as variáveis $z_{j}$ podem influenciar as elasticidades parciais de produção $X_{i}$.

A sua forma logarítmica pode ser representada da seguinte maneira:

$$
\ln Y=\ln A+\sum_{i=1}^{n} \beta_{\mathrm{i}}\left(Z_{j}\right) \ln X_{i}+\ln u ; \quad \operatorname{com} j=1, \ldots, r
$$

O efeito de uma variável influenciando a elasticidade da outra é dado pela multiplicação entre a primeira e o logaritmo da segunda. A equação (56) é linear nos parâmetros se as funções $\beta_{\mathrm{i}}\left(\mathrm{Z}_{\mathrm{j}}\right)$ também forem, podendo ser estimada pelo método dos mínimos quadrados ordinários, com a aplicação dos testes estatísticos apropriados.

\subsection{Descrição das Variáveis Independentes}

Dada a caracterização da variável dependente $Y_{\mathfrak{i}}$, as variáveis independentes que afetam direta e indiretamente a produção foram identificadas em cinco categorias. Esta classificação deve-se às peculiaridades de cada cultura : 
a) variáveis independentes ordinárias.

Estas variáveis afetam diretamente a produção e foram incluídas em todos os modelos. São as seguintes:

i) Área $\left(\mathbf{A} \mathbf{C}_{\mathbf{i}}\right)$ efetivamente colhida da cultura i, no ano agrícola 1995/96, expressa em hectares. Representa apenas a área ocupada com a cultura solteira. Como terra é um fator de produção primordial na agricultura, é esperada uma relação positiva entre $\mathrm{AC}_{\mathrm{i}}$ e $\mathrm{Y}_{\mathrm{i}}$.

ii) Mão-de-obra $\left(\mathrm{MO}_{\mathrm{i}}\right)$ empregada na cultura $\mathrm{i}$ ao longo do ano agrícola de 1995/96. Incluiu-se convenientemente o rendimento de homens, mulheres e crianças. Foi medido em dias-homens o trabalho do proprietário e de sua família, do trabalhador permanente e temporário. A força de trabalho padrão (dias-homens) foi considerada para aqueles com idade entre 20 e 60 anos. Aqueles com idade entre 10 e 15 anos, 15 até 19 anos e mais de 60 anos representam, respectivamente, $50 \%$, $80 \%$ e $80 \%$ da força padrão. Não foi feita diferenciação entre o trabalho efetuado por homens e mulheres, mesmo porque a participação do trabalho feminino junto às famílias pesquisadas foi inferior a $5 \%$. Em princípio, é esperada uma relação positiva entre $\mathrm{MO}$ e $\mathrm{Y}_{i}$;

iii) Variável que representa insumos básicos $\left(\mathbf{I B}_{\mathbf{i}}\right)$. Sempre existem dificuldades para uniformizar diferentes unidades, marcas, formulações e tipos de adubos, inseticidas e fungicidas, utilizados pelos produtores. Para contornar o problema, determinou-se o valor de todos estes insumos utilizados na cultura i no ano agrícola de 1995/1996 para cada produtor e sua unidade foi em reais. A variável sendo expressa em valor, também apresenta a vantagem de sugerir aspectos qualitativos, e portanto, deve-se esperar uma relação positiva entre o volume de gastos com insumos básico com a produção $\mathrm{Y}_{\mathrm{i}}$;

iv) A variável $\left(\mathbf{K}_{\mathbf{i}}\right)$ representa capital na forma de máquinas, motores e equipamentos de irrigação utilizados na cultura i em estudo durante o ano agrícola de 1995/96. Ela foi medida em reais, estimada com base no valor de reposição e considerando-se a vida útil de cada uma desta forma de capital. O valor estimado multiplicado pela relação área explorada pela cultura/ área total irrigada pelo produtor, 
deve ser $\leq 1$. Quanto maior for o montante de capital na forma de máquinas, motores e equipamentos de irrigação, espera-se maior produção e, em princípio, acredita-se numa relação positiva entre $K_{i}$ e $Y_{i}$.

v) Esta variável representa água $\left(\mathbf{A G}_{\mathbf{i}}\right)$ ministrada à cultura i durante o período de julho de 1995 a fevereiro de 1996, expressa em $\mathrm{m}^{3}$. É esperada uma relação positiva entre $A G_{i}$ e $Y_{i}$, considerando que água é imprescindível em projetos de irrigação.

b) Variáveis tecnológicas independentes específicas de efeito indireto.

Neste grupo são incluídas 2 categorias de fatores que podem influenciar a produção de coco e mamão representadas pelo número de plantas (NP) e idade das plantas (IP).

Número de plantas (NP) é uma variável que expressa adensamento do plantio. Produtores com uma mesma área podem ter números de plantas diferentes e o modelo pretende captar este adensamento influenciando a produção. A princípio, espera-se uma relação positiva entre NP e Y.

Idade das plantas (IP) significa anos de cultivo. A relação entre e IP e Y pode ser positiva num período inicial e negativa quando as plantas se tornam mais velhas. Não é possível estabelecer uma relação entre esta variável e a produção a priori.

Já no caso da cana-de-açúcar, o número de plantas é medido através da distância entre sulcos, que fornece uma indicação de densidade.

Distância entre sulcos (DS) é uma variável que expressa adensamento do plantio. Produtores com uma mesma área podem ter números de plantas diferentes e o modelo pretende captar este adensamento influenciando a produção. A priori, não se pode ter hipóteses na relação de DS com $Y$, porque adensamento maior pode não ter como resposta maior produção. Na verdade, existem muitos fatores interagindo para determinar o adensamento ótimo, tais como, fertilidade do solo, habilidade empresarial e qualidade da mão-de-obra, dentre outros. 
c) Variáveis tecnológicas independentes, de efeito indireto.

São variáveis que podem influenciar indiretamente a produção $Y_{\mathrm{i}}$. através do seu impacto sobre a elasticidade do fator $\mathrm{j}$. São representadas pela intensidade de uso do fator. Para melhor especificação destas variáveis, arbitrou-se que (MO/ha $)_{\mathrm{ij}}$, (IB/ha) $)_{\mathrm{ij}}$, $(\mathrm{K} / \mathrm{ha})_{\mathrm{ij}}$ e (AG/ha) $)_{\mathrm{ij}}$ significam, respectivamente, mão-de-obra/ha, valor dos insumos/ha, valor do capital/ha e água $\mathrm{em} \mathrm{m}^{3} /$ ha. Cada uma destas variáveis pode ser expressa na forma linear, quadrática ou cúbica.

d) Variáveis sócioeconômicas independentes, de efeito indireto.

São variáveis que podem ser testadas em todas as culturas para estudo de seu efeito indireto sobre a produção $Y$, através do seu impacto sobre a elasticidade do fator $j$. São representadas por:

i) escolaridade $(\mathrm{AE})_{\mathrm{ij}}$, que foi medida pelo número de anos de estudo do produtor. Acredita-se numa relação positiva entre escolaridade e produção;

ii) idade $(\mathrm{AV})_{\mathrm{ij}}$, que foi medida pelo número de anos de vida do produtor. Quanto a esta variável; não pode ser estabelecida nenhuma relação a priori com a produção.

e) Variáveis independentes de efeito direto.

Esta é uma variável binária utilizada para verificar a existência ou não de diferença na produção i em decorrência da assistência técnica $(\mathrm{AT})_{\mathbf{i}}$ recebida pelo produtor. Atribuiu-se o valor 1 para produtores que receberam assistência técnica nas culturas na safra agrícola 1995/96 e zero para aqueles que não a receberam. Não foi considerada a frequiência com que estes produtores receberam assistência técnica. Acredita-se numa relação positiva ente $\mathrm{AT}_{\mathrm{i}}$ e $\mathrm{Y}_{\mathrm{i}}$.

Para todas as culturas, os modelos testados deverão contemplar as variáveis da categoria (a). Alternativamente, são testados modelos que incluam a variável da categoria (e) para verificar a influência ou não da assistência técnica sobre a produção das culturas a serem estudadas. 


\subsection{Considerações Sobre as Variáveis Utilizadas nos Modelos Apresentados}

São inúmeros os fatores que interferem direta ou indiretamente no produção. $\mathrm{O}$ pesquisador pode ser levado a excluir variáveis importantes neste processo, gerando estimadores viesados, ou incluir variáveis de pouca relevância e/ou intercorrelacionadas, trazendo problemas de multicolinariedade. Então, o dilema de se obter estimativas viesadas ou imprecisas está sempre presente quando se pretende ajustar funções de produção. O importante então é minimizar esta provável possibilidade e fazer as ressalvas necessárias quanto às limitações da qualidade dos resultados obtidos.

Uma questão relevante refere-se aos erros de medida. Nesta pesquisa, por exemplo, a mera observância dos dados "oficiais" fornecidos pela cooperativa dos irrigantes quanto a produção de coco, iria contribuir para gerar este tipo de problema, porquanto os dados de produção da cooperativa diferem das informações oriundas dos produtores entrevistados. As despesas de comercialização representam o seguinte percentual sobre o valor da produção: Funrural $(2,84 \%)$, taxas e comissões $(6,3 \%)$, capatazia $(1,95 \%)$, colheita $(4,4 \%)$ e frete $(2,53 \%)$. Para evitar parcela destes custos, principalmente Funrural, taxas e comissões, parte da produção é vendida "por fora", num volume que representa $30 \%$ da produção total. Obviamente, os dados da produção de coco utilizados nesta pesquisa foram os fornecidos pelo produtor. Quanto aos dados de produção da cana-de-açúcar, quase que integralmente vendida para a única usina na região, pelo menos na etapa I do projeto e a de mamão, sem a interferência da cooperativa, não se constatou os problemas verificados com dados da produção do coco.

Alguns produtores relataram a não utilização de insumos no ano agrícola de 1995/96, e, questionados sobre o motivo, alegaram terem feito adubações (principalmente orgânica) no ano agrícola anterior. Isto ocorreu com o coco e a cana-deaçúcar. Nesse caso, substituiu-se o valor zero, registrado nos questionários, pelo valor arbitrário 1, o que pouco representa em termos absolutos. Pode-se aceitar, portanto, que, na relação da produção com o uso de insumos, além dos valores levantados para o ano 
agrícola de 1995/96, existe um reflexo na produção decorrente também de algum tipo de efeito residual, não considerado neste estudo. Esta é uma limitação, dado o pressuposto de monoperiodicidade, ou seja, a produção de um período independe da anterior e da subseqüente ao ano agrícola 1995/96.

Outro problema surgiu com respeito à variável capital. Primeiro foi a não inclusão de todas as modalidades deste fator, dada a grande possibilidade de erros para desagregação da participação do capital na cultura específica em estudo. Considerou-se apenas o capital diretamente utilizado na irrigação. Seria inviável tentar desagregar outras formas de capital, como instalações, por exemplo. Assim, utilizou-se na sua forma de participação efetiva, considerando-se apenas a depreciação, sem envolver juros e despesas de reparos. Como este capital é utilizado em diferentes culturas, o valor da depreciação foi multiplicado pela relação área irrigada com a cultura em estudo/área irrigada total.

Quanto à mão-de-obra, considerou-se as quantidades utilizadas apenas no ano agrícola das culturas em produção. Não foi computado o trabalho efetuado no período de implantação das culturas. Como estas são permanentes, ou semi-permanentes, aqueles gastos com preparo de solo, plantio e manutenção também não foram considerados.

Para determinar a quantidade de água ministrada às culturas, levantou-se junto a cada produtor o número de aspersores, tempo médio gasto para uma irrigação completa, turno de rega, número total de irrigações integrais no ano agrícola de 1995/96 e a vazão. Para cada aspersor, foi determinado o tempo que a água leva para encher um recipiente de volume conhecido (20 litros). Segundo Bernardo (1982), este é um método simples, barato, que requer poucos equipamentos e apresenta razoável precisão. Ainda sobre o uso da água, existem algumas dificuldades para uma acurada medida de resposta da produção à água utilizada na irrigação.

i) A agricultura, sendo um processo biológico, é sujeita a complexas leis regidas pela composição gamética das plantas, condições ambientais e interação entre estes fatores, o que confere alta influência na produção. A decisão no uso da água é feita pôr 
muitos produtores, cada um representando pequena proporção da água total utilizada;

ii) A resposta à irrigação é sensível à taxa com que a água é combinada com outros fatores. Entre outros, o nível de nutrientes no solo é talvez o principal deles. Investimentos de capital, terra e distribuição do sistema de irrigação são importantes. Capital pode substituir água (dependendo do tipo de irrigação) e influencia a produtividade da água;

iii) A resposta da produção agrícola à irrigação pode ser inibida por concentração de sais no solo, que atua e se localiza na zona da raiz das plantas;

iv) As mudanças tecnológicas podem afetar a resposta da produtividade física à irrigação e esta pode não ser percebida inicialmente. A introdução de variedades melhoradas pode gerar um incremento da produtividade física da água.

v) Da mesma maneira, a existência de variabilidade genética reflete-se em termos de produção, à aplicação da água.

vi) A comparação entre produção total e a quantidade de água aplicada ao longo de todo o ciclo produtivo, pode ignorar muitas características determinadas por fatores biológicos. Em cada fase da cultura, tais como, desenvolvimento vegetativo, floração, e frutificação, os requerimentos de água são diferenciados. O rendimento de muitos produtos, por exemplo, é altamente sensível à disponibilidade de umidade durante o período da floração. Caso a umidade do solo seja zero ou negativa, o que é comum no semi-árido, a produtividade tende a crescer no tempo com o uso da água.

Finalmente, um comentário a respeito da omissão de variáveis, como trabalho mecânico, variedades cultivadas e crédito rural.

O trabalho mecânico participa basicamente das operações de preparo de área, que, no caso de culturas permanentes, ocorrem no período de implantação.

As variedades exploradas são praticamente as mesmas, para as três culturas, quais sejam, anão verde para o coco, Havaí para o mamão e 45-X para cana-de-açúcar. Cerca de $5 \%$ dos produtores exploram a variedade de cana CB-3825. 
Um conjunto de problemas administrativos impede o fornecimento de crédito formal para os irrigantes, dentre os quais se destaca a inadimplência de crédito pecuário fornecido em 1993 por bancos oficiais, tanto para a cooperativa como para os associados. Dada esta situação, surgiram neste período formas de crédito informal específicas para cada cultura. Grande parte dos produtores de cana-de-açúcar, especialmente os situados na etapa I do projeto, foram financiados pela usina Agrovale. Cada produtor utiliza quatro horas de trabalho de trator para preparo de 1 ha do solo e uma diária para cada tonelada colhida de cana. O corte da cana é feito pela usina. No momento de venda do produto, estas despesas são subtraídas do valor da produção. Além disso, a usina fornece, em média, seis ton/ha de cana-semente (toletes) para cada produtor. Essa quantidade é abatida da quantidade total de cana vendida para a usina. $O$ coco é financiado pela cooperativa apenas na fase de colheita e no custeio do transporte. O valor desse custeio é recuperado pela cooperativa através de uma dedução de $8,89 \%$ sobre o valor da venda efetuada. Já as despesas de implantação, manutenção e comercialização de mamão não contam com nenhum tipo de financiamento.

Esta pode ser, talvez, uma explicação da influência do crédito no tamanho das áreas cultivadas, que, no projeto em estudo, é liderada pela cana-de-açúcar, vindo em seguida pelo coco e finalmente, pelo mamão. 


\section{ANÁLISE E DISCUSSÃO.}

\subsection{Cultura do coco.}

Vários modelos foram testados para estimar a função de produção de coco (ver Tabela 30, apêndice 2). A produção de coco ( $Y_{1}$ ) (em milheiros) é a variável dependente e as independentes são: área cultivada ( $\mathrm{AC})$, trabalho humano (MO), valor dos insumos básicos (IB), valor do capital na forma de materiais e equipamentos de irrigação $(K)$ e água ( $A G)$.

Foram testadas algumas variáveis que poderiam influenciar indiretamente a produção de coco. Examinou-se as variáveis idade e escolaridade do produtor e tamanho de sua família, todas de natureza social. Representando a tecnologia, utilizou-se a intensidade de uso dos fatores e a idade das plantas. Considerando-se diferentes posições de influência das variáveis não convencionais, a educação (AE), influenciando a produtividade do capital $(\mathrm{K})$, foi a que melhor se comportou.

A seleção das variáveis foi feita com o intuito de considerar os fatores que realmente interagem na produção. Procurou-se, inicialmente, construir um modelo fundamentado na lógica física, biológica e econômica do sistema de produção do coco. Os critérios foram discutidos no capítulo anterior.

Num modelo de produção total, assume-se o risco proveniente de multicolinearidade com todas as suas implicações. A eventual existência de alta correlação entre variáveis independentes é fato ditado pela realidade. As medidas 
necessárias para solução deste problema, devem ser tomadas caso a caso, quando isto é pertinente.

A cultura do coco, conforme comentado, é de implantação recente no projeto. Apenas 15\% dos produtores atuais produziam coco antes de 1992, mesmo assim de forma incipiente. A cultura vem despontando como uma das alternativas econômicas mais promissoras do projeto.

Inicialmente, estimou-se os coeficientes de correlação simples entre as variáveis que entrariam nos modelos testados. Obteve-se uma idéia abrangente das variáveis mais relevantes para explicação da produção de coco, safra 1995/96. Em seguida, foram feitas estimativas preliminares para observar o comportamento simultâneo destas variáveis. A Tabela 36 (apêndice 3) mostra que as correlações entre as variáveis independentes não são elevadas. A variável terra $(\mathrm{AC})$ tem uma correlação de 0,76 com a variável número de plantas (NP). Como ambas podem explicar a escala da produção de coco, optou-se pela manutenção da variável (AC) no modelo por ser mais significativa estatisticamente, sendo feita a exclusão de NP.

Greene (1990), examina vários métodos para análise de multicolinearidade. Num deles, o autor refere-se a recomendação de Belsley et al. (1980) como uma boa sugestão para tratar do problema. Basta utilizar as raízes características ou eingenvalue ( $\lambda$ ) obtidos da matriz $X^{\prime} X$. A raiz quadrada do resultado da divisão entre o máximo $\left(\lambda_{\max }.\right)$ pelo mínimo $\left(\lambda_{\min }\right)$, identificado como condition number $(\gamma)$, não deve superar 20. Se isto ocorrer, existem indícios de que podem ocorrer sérios problemas de multicolineaidade. Assim, na análise de colinearidade para a cultura do coco, o valor encontrado foi igual a 3,7 (ver Tabela 35, apêndice 3). Tampouco pode-se rejeitar a hipótese $\mathrm{H}_{\mathrm{o}}$ de que os erros da regressão do coco sejam homocedásticos, conforme o teste de Glejser (ver Tabela 34, apêndice 3).

A variável MO foi incluída em todos os modelos, ao passo que trabalho mecânico foi descartado. Sua relevância é observada apenas na fase de preparo do solo, que ocorre no ano agrícola em que a planta ainda não se encontra em fase produtiva. 
Procedeu-se, assim, por ser uma cultura permanente. Em culturas anuais, o trabalho mecânico (quando existente) deve ser considerado, pois todas as fases de cultivo são realizadas no mesmo ano agrícola.

Os valores de IB (calcário, adubos e defensivos) foram incluídos nos modelos e utilizou-se um artifício matemático. Três produtores da amostra responderam não utilizar qualquer tipo de insumo no ano agrícola investigado e dois afirmaram ter utilizado quantidades ínfimas. Alegaram falta de crédito e/ou terem feito correções de solo e aplicações de adubo orgânico no ano anterior. A solução encontrada para incluir esta importante variável no modelo foi substituir o valor zero destes produtores que não usaram insumos por uma constante arbitrária igual a 1 (ver Tabela 26, apêndice 1). Este procedimento não traz nenhum prejuizo para as estimativas, dado que foram apenas três observações no caso do coco, que sofreram alterações irrisórias. Mesmo assim, esta variável em nenhum modelo testado é significativamente diferente de zero, embora o valor do parâmetro estimado seja sempre superior ao do seu erro padrão, exceto no modelo IV.

Nos modelos testados, verificou-se que os parâmetros de $K$, na forma de máquinas e equipamentos de irrigação, apresentam uma sensível variação. No modelo III, por exemplo, este chega a ser negativo. Do ponto de vista estatístico, isto pode se dever a uma alta correlação entre o fator educação na sua forma linear e quadrática $(0,94)$, que influenciam o capital e que se encontram incluídos simultaneamente no modelo III.

O valor do capital foi medido pelo somatório da depreciação dos diversos itens levantados. Os valores obtidos não foram ponderados pelos dias de uso mas, foram ponderados pela relação da área cultivada de coco com área total irrigada, para melhor evidenciar a especificidade deste fator na cultura. O juros sobre o capital empatado não foram incluídos no cálculo,

O capital é a variável que apresenta maior dificuldade para uma correta aferição. Além do problema da divisibilidade e de ser muito difícil medir sua ociosidade, 
ele não permanece constante durante todo o período produtivo. O seu potencial de fornecer serviços correntemente se reduz. Por ocasião da pesquisa, pôde-se observar que muitos produtores utilizam equipamentos fornecidos ainda pelo DNOCS, com 10 anos e mais de uso, mantidos de forma precária e com adaptação artesanal. O valor médio deste fator utilizado pelos produtores é muito baixo, em torno de $\mathrm{R} \$ 58,00$. A única reposição considerada efetiva é a dos bicos de aspersores de metal substituídos por bicos de plástico. Para o cálculo do capital, considerou-se as referências de vida útil máxima, sem atentar para estas situações específicas. Observou-se, também, que, de forma generalizada, não ocorre coexistência de produtores com equipamentos obsoletos ao lado de produtores com equipamentos novos, mais modernos e consequentemente, mais eficientes. Existe uma certa uniformidade qualitativa do capital na forma de equipamento de irrigação utilizado.

No modelo I, a variável educação, expressa em anos de estudo do produtor, influencia a elasticidade do capital e encontra-se na forma linear. Os parâmetros estimados para os valores dos insumos e do capital não são significativos ao nível de 10\%. No modelo II, a variável educação encontra-se na forma quadrática e apenas a variável valor de insumos apresenta seu coeficiente não significativo ao nível de $10 \%$. Mas o valor do parâmetro estimado supera o seu erro padrão.

Os coqueirais foram formados em sua grande maioria a partir da década de 90 , e as diferenças de idade das plantas do conjunto de produtores é muito pequena para ter uma influência importante sobre a produção.

Mas, uma forma de superar a falta de experiência e tradição no cultivo do coqueiro é através da habilidade gerencial. Isto pode ser medido pelo grau de escolaridade do produtor. Embora apresentem, em média, baixa escolaridade ${ }^{30}$, o número de anos de estudo do produtor de coco pode ser uma proxy de habilidade gerencial. O modelo II selecionado demonstra que, na medida em que o produtor aumenta sua escolaridade, o capital passa a ter uma influência crescente sobre a

${ }^{30}$ Com 2,5 anos de estudo. 
produção. Isto talvez possa ser explicado por um melhor manejo dos equipamentos em termos do número de horas de serviço, distribuição mais homogênea da água e horário de irrigação mais apropriado. Uma manutenção adequada do capital pode significar redução das perdas de água, traduzindo-se num maior rendimento do fator.

Uma variável binária foi incluída no modelo $\mathrm{V}$ para testar a influência da assistência técnica (AT) na produção. Ele mostra que o coeficiente de AT não é significativo. Isto pode ser atribuído à falta de regularidade do serviço de extensão no Estado, que, a partir de 1990, vem passando por crises financeiras sucessivas, sem os meios, freqüência e constância requeridos. Além disso, com o processo de emancipação preconizado pelo governo, o DNOCS retirou a maioria dos seus técnicos da área do projeto. O conhecimento acumulado ditado pela escolaridade tem um efeito mais efetivo sobre a produção do que uma assistência técnica da forma ora descrita.

Comparando-se o modelo selecionado II (Ulveling-Fletcher) com o modelo IV (Cobb-Douglas tradicional) do apêndice 2, verifica-se que o primeiro é superior tanto em termos do coeficiente de determinação como na significância dos parâmetros. Os valores dos coeficientes estimados são relativamente parecidos, mas, o modelo II é melhor.

A função de produção de coco tem a seguinte forma algébrica:

$$
Y=0,3103 \cdot A C^{0.2999} \cdot M O^{0.2258} \cdot I B^{0.0417} K^{0.1705+0,0014(A E)^{2}} \cdot A G^{0.2486}
$$

Pelo valor dos coeficientes, terra e água são os fatores que causam maior impacto na produção do coco, seguidos de perto pelo fator trabalho. Os insumos básicos apresentam pouca influência sobre a produção.

Enquanto as elasticidades parciais de $\mathrm{AC}, \mathrm{MO}, \mathrm{IB}$ e $\mathrm{AG}$ são constantes, a elasticidade de $\mathrm{K}$ é diretamente proporcional ao grau de escolaridade (AE) do produtor, medido pelo número de anos de estudo. Fixando-se a variável educação nos seus níveis mínimo, médio e máximo, obtém-se as seguintes elasticidades parciais de K: 
$\mathrm{AE}$ mínimo $=1 ; \mathrm{E}_{\mathrm{k}}=0,1719 ;$

$\mathrm{AE}$ médio $=2,54 ; \mathrm{E}_{\mathrm{k}}=0,1796$;

$\mathrm{AE}$ máximo $=11 ; \mathrm{E}_{\mathrm{k}}=0,3399$.

$\mathrm{Na}$ medida em que o grau de escolaridade aumenta, cresce a influência do fator K sobre a produção de coco. O número de anos de estudo do produtor significa conhecimento acumulado, que, de alguma forma sugere que o produtor apresente melhores condições no manejo dos equipamentos.

Por definição, a elasticidade total de produção (e) é igual à soma $\left(\Sigma b_{i}\right)$ das elasticidades parciais de produção. Como $\left(\Sigma b_{i}=0,995\right)$ a eq. 57 indica rendimentos constantes à escala. $\mathrm{O}$ aumento da produção ocorreria na mesma taxa de um aumento simultâneo e homogêneo dos fatores.

A Tabela 10 mostra que não existem fatores sendo utilizados no estágio 3. Mas a utilização dos fatores não se encontra no ponto ótimo no estágio 2. Todos poderiam ter seu uso incrementado porque o valor do produto marginal (VPMgX) de cada fator é superior aos seus respectivos preços de mercado. Isto mostra que existe uma forte tendência de ampliação da área cultivada com coco, que levaria ao incremento no uso dos demais fatores.

Como o preço da água não é dado pelo mercado e sim fixado pelo governo, sua análise será feita separadamente na seção seguinte. Uma análise de longo prazo iria requerer que as quantidades de cada fator se ajustassem em função dos próprios preços, e das quantidades e preços dos demais fatores. 
Tabela 10 - Valor do produto médio (VPMe $\mathrm{xi}_{\mathrm{i}}$ ) (exceto água), valor do produto marginal (VPMg $\mathrm{Xi}_{\mathbf{i}}$ ), preços dos fatores $\left(\mathrm{Px}_{\mathbf{i}}\right)$ e relação entre os valores dos produtos marginais e os preços fatores $\left(\mathrm{VPMg}_{\mathrm{Xi}} / \mathrm{Px}_{\mathrm{i}}\right)$, incluídos na função de produção de coco, projeto Curu-Paraipaba, Estado do Ceará, ano agrícola 1995/96.

\begin{tabular}{lrrrc}
\hline Fatores de produção & VPMexi & VPMgxi & Pxi & VPMgxi/Pxi \\
\hline Terra (ha) & $3.640,70$ & $1.091,84$ & 390,00 & 2,80 \\
Mão-de-obra (h/d) & 54,20 & 12,24 & 4,00 & 3,06 \\
Valor dos insumos (R\$) & 30,04 & 1,32 & 1,09 & 1,21 \\
Equip. de irrigação (R\$) & 62,50 & 11,22 & 1,05 & 10,65 \\
\hline
\end{tabular}

Fonte: Dados da pesquisa.

Se a TMS entre $\mathrm{Xi}$ e $\mathrm{Xj}$, vista na Tabela 11 , for igual ao inverso da relação entre os respectivos preços (Pxj/Pxi) da Tabela 12 para um dado volume de produção, tem-se uma combinação de 2 (dois) fatores com custo mínimo.

Tabela 11 - Taxa marginal de substituição entre os fatores (exceto água) incluídos na função de produção de coco do projeto Curu-Paraipaba, Estado do Ceará, ano agrícola 1995-96.

\begin{tabular}{lrccc}
\hline TMS xixj & $A C$ & $M O$ & $I B$ & $K$ \\
\hline AC & 1,00 & 0,01 & 0,00 & 0,01 \\
MO & 89,20 & 1,00 & 0,10 & 0,92 \\
IB & 827,15 & 9,27 & 1,00 & 8,50 \\
K & 97,31 & 1,09 & 0,12 & 1,00 \\
\hline
\end{tabular}

Fonte: Dados da pesquisa. 
Para uma produção de coco igual à média geométrica dos dados observados na amostra (14,45 milheiros), seria aconselhável aumentar a intensidade de uso dos fatores trabalho e capital por unidade de área. Como visto, investimentos em educação podem contribuir para aumentar os retornos à escala, o que significa melhorar a produtividade dos fatores.

Tabela 12 - Relação entre os preços dos principais fatores (exceto água) utilizados no projeto de irrigação Curu-Paraipaba, Estado do Ceará, ano agrícola 199596.

\begin{tabular}{lrrrc}
\hline & PAC & PMO & PIB & PK \\
\hline PAC & 1,00 & 0,01 & 0,02 & 0,002 \\
PMO & 97,50 & 1,00 & 0,27 & 0,26 \\
PIB & 357,79 & 3,66 & 1,00 & 0,96 \\
PK & 370,22 & 3,79 & 1,03 & 1,00 \\
\hline
\end{tabular}

Fonte: Cooperativa dos Irrigantes do Perímetro Curu-Paraipaba

5.1.1. A demanda de água para coco.

A substituição dos valores médios (geométricos) de AC, MO, IB e AG na eq (57) tem-se:

$$
Y_{l}=1,6574 .(A G)^{0,2486}
$$


Multiplicando-se a eq. (58) por 171, pode-se obter uma função de produção representativa da população que explora coco no projeto, que fica:

$$
Y_{1 t}=283,41 \cdot(A G)^{0,2486}
$$

pode-se, então, determinar o PMg da água:

$$
\mathrm{PMg} A G=70,45 \cdot(\mathrm{AG})^{-0,7514}
$$

Multiplicando-se a equação (60) pelo preço do milheiro de coco ( $\mathrm{R} \$ 200,00$ ), obtém-se o valor do produto marginal da água (VPMgAG) que no equilíbrio, é igual ao preço da água. Então, a função de demanda da água para a cultura do coco pode ser assim expressa:

$$
P_{A G}=14.091,42 \cdot\left(\mathrm{AG}_{\mathrm{C}}\right)^{-0,7514}
$$

\subsection{Cultura do mamão}

Vários modelos foram testados considerando diferentes posições das variáveis que afetam indiretamente a produção de mamão. Os cinco melhores resultados são contemplados na Tabela 31 do apêndice 2 . O modelo selecionado foi o de número I.

A produção de mamão $\left(\mathrm{Y}_{2}\right)$ em toneladas é a variável dependente. São as seguintes as variáveis independentes influenciando diretamente a produção: Área cultivada em hectares (AC), trabalho humano (MO), valor dos insumos básicos(IB), valor do capital na forma de materiais e equipamentos de irrigação (K), e água (AG). 
Considerou-se uma variável tecnológica, afetando indiretamente a produção do mamão, representada por densidade de plantio (NP/ha) e uma variável sócioeconômica representada pela idade do produtor (AV). A densidade de plantio está expressa em mil plantas/ha e influência a elasticidade parcial de MO. A idade do produtor influencia a elasticidade parcial da água.

A cultura do mamão foi uma das incluídas na proposta de diversificação que o perímetro experimentou no inicio dos anos 90 . Seu cultivo em alguma escala começou antes da cultura do coco, embora venha evoluindo mais lentamente. Em 1988, a área cultivada com mamão representava apenas $1 \%$ da área total irrigada. No ano agrícola 1995/96, representou $10 \%$ da área total e vem mostrando uma tendência para estabilização.

É uma cultura que apresenta um razoável grau de risco, tanto no tocante à produção como na sua comercialização. Estas são fortes razões pelas quais a área cultivada com mamão nos últimos anos não ultrapassar 70 ha em todo o projeto. Os produtores exploram áreas pequenas, com média de 0,72 ha.

A alta incidência de pragas e doenças, principalmente nematóides, são grandes limitantes ao incremento dos cultivos, em especial pela restrição dos irrigantes ao crédito rural. A falta de agroindústrias na região e a maneira como os frutos são manuseados, transportados e comercializados, levam a perdas que podem atingir até $30 \%$ (Pinto Filho, 1994). O mercado de frutos in natura é mais restrito, com coeficiente de variação no preço médio mensal ao longo do ano agrícola de 1994/95 de $20 \%$.

Considerando estas características da cultura, inicialmente, estimou-se os coeficientes de correlação simples entre as variáveis independentes. A variável terra (AC) é altamente correlacionada $(0,96)$ com a variável número de plantas (NP) e a exemplo do que ocorreu com a cultura do coco, foi mantida no modelo apenas a variável $\mathrm{AC}$ por sua maior significância estatística. Além disso, tanto $(\mathrm{AC})$ como o número de plantas (NP), podem explicar o tamanho da exploração. 
Mas a variável NP/ha afeta indiretamente a produção de mamão, através da influencia positiva sobre a elasticidade parcial da produção de MO. O número de plantas/ha (NP/ha) pode significar intensidade de uso do capital. Todos os investimentos e gastos com a cultura são materializados e constituídos no número de plantas exploradas.

Em nenhum modelo da Tabela 31 do apêndice 2, o coeficiente estimado para o fator terra é significativamente diferente de zero ao nível de $10 \%$. No modelo selecionado, isto ocorre ao nível de $30 \%$, mas o valor do coeficiente é superior ao seu erro padrão. Isto talvez, em decorrência da alta correlação (superior a 80\%) entre a terra com MO, $\mathrm{K}$ e, principalmente, com IB $(0,93)$, conforme mostra a tabela 37 do apêndice 3. Como já dito anteriormente, problemas de multicolinearidade ocorrem com certa freqüência em modelos de produção total, considerando-se a proporcionalidade entre o uso dos fatores com a área cultivada. Mas com os cálculos utilizando-se os eingenvalue $(\lambda)$ obtidos da matriz X'X na análise de colinearidade para a cultura do mamão, mostra um valor igual a 5,36 para o condition number não indicando problemas mais sérios de multicolinearidade (ver Tabela 35, apêndice 3). Também não se rejeita a hipótese $H_{0}$ de que os erros da regressão do mamão sejam homocedásticos, conforme o teste de Glejser (ver Tabela 34, apêndice 3).

Retirando parte ou integralmente as variáveis de efeito indireto sobre a produção nos modelos testados, a elasticidade do fator AC torna-se negativa. Como não existe nenhuma razão forte para se acreditar no uso excessivo de terra, ganha reforço atribuir-se importância às variáveis de efeito indireto. A qualidade de ajustamento do modelo selecionado I é muito boa em relação aos demais, com coeficiente de determinação igual a $82,04 \%$ e o valor de "F" igual a 13,7 .

O mamoeiro absorve muita mão-de-obra, cada produtor utiliza, em média, 157 diárias, sendo a colheita a atividade que mais requer este fator. No mamão, ao contrário do coco, a colheita é feita pelo próprio produtor e sua família. Uma grande vantagem desta cultura é permitir uma boa distribuição do trabalho familiar, que é um fator 
relativamente menos escasso que os demais. A colheita é feita 2 a 3 vezes por mês, possibilitando menor oscilação da renda do produtor ao longo do tempo. No modelo I, o coeficiente estimado do fator trabalho é significativamente diferente de zero ao nível de $19 \%$.

A variedade "havấ" é a mais cultivada, iniciando a produção econômica com 10 meses após o plantio, podendo a planta produzir economicamente até 18 meses consecutivos.

O coeficiente de regressão da variável valor do capital $(K)$ é negativo e estatisticamente diferente de zero ao nível de $1 \%$. É uma constatação surpreendente num projeto que tem restrições ao crédito.

Em todas as tentativas de ajustamentos feitas com o mamão, o coeficiente do (K) sempre mostrou-se estável, negativo e estatisticamente significante. Os dados da amostra, informam que a produtividade média do mamão foi de 20,2 ton./ha. Os produtores que usam mais capital, ou seja, que apresentam uma relação capital por unidade de área acima da média da amostra, obtiveram uma produtividade média de 17 ton./ha. Uma explicação plausível para esta aparente contradição pode ser o exercício de praticas ilícitas no projeto. No decorrer da pesquisa de campo, verificou-se que alguns produtores substituem os bicos de aspersores de metal invioláveis fornecidos obrigatoriamente pelo DNOCS, por aspersores de plástico, cerca de seis vezes mais baratos. Estes possibilitam ampliar o diâmetro dos orifícios, aumentando a vazão da água e diminuindo as disponibilidade para aqueles que não usam tais expedientes.

O capital apresenta alta correlação $(0,82)$ com a terra, talvez em razão da sua ponderação pela área cultivada com mamão em relação às de outras culturas irrigadas, para determinação do seu valor.

Nos modelos testados, a variável valor dos insumos básicos (IB) mostrou-se estável com coeficiente significativo a $1 \%$, evidenciando sua relevância no processo produtivo do mamão. O uso de insumos modernos requer orientação técnica e sua ausência é considerada o maior problema no projeto Curu-Paraipaba (Queiroz, 1992). 
Curiosamente, o modelo $\mathrm{V}$ mostrou que a variável binária (AT) representando assistência técnica não é significativa (ver Tabela 31, apêndice 2).

Em abordagem anterior, o modelo selecionado I revela que a elasticidade parcial da água é influenciada pela idade (AV) do produtor. Em todas as tentativas de ajustamento efetuadas, esta variável apresentou uma sensível e persistente influência na elasticidade parcial da água.

Isto pode significar que produtores mais idosos, na faixa etária que vai da idade mínima até um pouco acima da média da amostra (52 anos), apresentam tendência decrescente na produtividade da água. Esse fato pode está relacionado com aversão ao risco e maior resistência ao associativismo. Produtores mais idosos dedicam menos esforços a exigente cultura do mamão. Os dados da amostra indicam que os produtores mais jovens, com idade abaixo da média, utilizam $30 \%$ mais mão-de-obra de que os mais idosos. A maior concentração de irrigantes incluídos na categoria de não-sócios da cooperativa do projeto Curu-Paraipaba pertencem aos mais idosos (Queiroz, 1992, p.39).

Quanto a influência positiva na produtividade da água dada pelo termo quadrático, pode ter alguma relação com a maior experiência no manejo dos equipamentos de irrigação e quanto a localização do irrigante no projeto. Este foi implantado em 1977. Os produtores mais velhos situam-se mais próximos das fontes de água e, portanto, nos trechos iniciais das tubulações. Nestas áreas, ocorreram os primeiros assentamentos. Segundo Queiroz (1992), 84,15\% dos irrigantes encontravamse instalados no perímetro em 1991, num período que variava de 10 a 14 anos. Parte destes fixaram residência no perímetro desde 1977, ano de inicio do seu funcionamento. Na porção inicial do canal, a pressão da água é sabidamente maior, o que confere uma disponibilidade mais efetiva de água para irrigação, dentro do sistema de distribuição prevalecente. Além disso, as perdas de água decorrentes da manutenção inadequada, ou mesmo agravadas pelo tempo de uso, intensificam-se para os produtores residentes mais longe da fonte. Os dados desta pesquisa mostram que os produtores com idade acima da 
média da amostra, utilizam no mamão $15.895 \mathrm{~m}^{3}$ de água/ha, enquanto que os com média abaixo, usam $14.500 \mathrm{~m}^{3}$ de água/ha.

Além disso, uma prática corrente e específica da cultura do mamão no controle de nematóides é diminuir os níveis de aeração do solo, via utilização da água em quantidades além do necessário pelas plantas. Talvez isso ocorra para compensar a falta de crédito e de maior controle sobre a água. Se for um fato verdadeiro, além da irrigação, o fator água prestaria um serviço adicional à produção de mamão via controle de nematóides. Dados da amostra indicam que, no mamão, são aplicados em média volumes de água/ha superiores a $45 \%$ do que é fornecido a cultura do coco. Por razões já expostas, produtores mais idosos teriam mais condições de adotar esta prática bizarra.

Dada a inexistência de estudos específicos que assegurem os motivos apresentados para explicar a influência da idade sobre a produtividade da água, a análise feita nesse aspecto deve ser vista com reservas. Considerando as características do atributo idade do produtor atuando sobre a elasticidade parcial da água e a densidade de plantio sobre a elasticidade da mão-de-obra, foi selecionado o seguinte modelo:

$$
Y=0,13 A C^{0.2139} M O^{0.2028+0.0336(N P / h a)^{2}} I B^{0.4281} K^{-0.52} A G^{0.6036-0.014 .3(A V)+0.00014(A V)^{2}}
$$

O modelo I da Tabela 31 do apêndice 2 (Ulveling-Fletcher) expresso na eq.(62) é melhor do ponto de vista estatístico do que o modelo $\mathrm{V}$, do tipo Cobb-Douglas tradicional. Ele possui maior coeficiente de determinação e maior valor de $F$, o que significa melhor ajustamento. No modelo $\mathrm{V}$, os coeficientes das variáveis terra e água não apresentam significância estatística, a exemplo do modelo selecionado, mas sugerem que a terra está sendo usada em excesso.

Enquanto as elasticidades parciais de produção da terra, valor de insumos e capital são constantes, as da água e mão-de-obra dependem respectivamente da idade do 
produtor e do número de plantas/ha ${ }^{31}$. Fixando a idade do produtor nos seus valores mínimo, médio e máximo, obtém-se as seguintes elasticidades parciais de produção da água:

$\mathrm{AV}$ mínimo $=26 ; \mathrm{E}_{\mathrm{ag}}=0,3264$

$\mathrm{AV}$ médio $=52 ; \mathrm{E}_{\mathrm{ag}}=0,2386$;

$\mathrm{AV}$ máximo=68; $\mathrm{E}_{\mathrm{ag}}=0,2786$.

$\mathrm{Na}$ medida em que a idade do produtor sai do seu mínimo, a elasticidade parcial da água vai diminuindo. Como já afirmado, a eq.(62) mostra uma tendência crescente desta elasticidade, quando a idade ultrapassa um pouco a sua média.

$\mathrm{Na}$ medida em que a densidade de plantio cresce, a elasticidade parcial de produção do fator trabalho reage positivamente. Fixando-se esta variável em seus valores mínimo, médio e máximo, estas elasticidades assumem os seguintes valores:

$\mathrm{NP} /$ ha mínimo $=0,625 ; \mathrm{E}_{\mathrm{mo}}=0,2159 ;$

$\mathrm{NP} /$ ha médio $=1,5971 ; \mathrm{E}_{\mathrm{mo}}=0,2885$

$\mathrm{NP} /$ ha máximo $=2,5 ; \mathrm{E}_{\mathrm{mo}}=0,4128$.

Sendo o número de plantas/ha uma forma de capital, é consistente esperar que, quando este aumenta, haja influência positiva sobre a elasticidade da mão-de-obra, dado que a intensidade de uso de um fator contribui para aumentar o produto marginal do outro.

Os retornos de escala da função de produção desta fruta diminuem quando, simultaneamente, a densidade de plantio e idade do produtor crescem a partir de seus pontos mínimos. Quando estas variáveis passam do ponto mínimo para o médio, as elasticidades totais de produção caem de 0,6643 para 0,6491 . Os retornos à escala passam a crescer quando os efeitos simultâneos ocorrem nos valores acima de sua média.

31 Esta variável está expressa em mil mamoeiros/ha para reduzir o número de casas decimais do coeficiente. 
Dado que o mamão apresenta retornos decrescentes, torna-se importante conhecer quais e como se comportam os fatores frente a essa cultura, com vistas a influir sempre positivamente no seu rendimento.

A Tabela 13 mostra que os valores do produto médio são superiores aos do produto marginal de cada fator, além de todos serem positivos, com exceção do capital. Pelas razões já citadas, isto significa que aqueles fatores estão sendo empregados na estágio II, que é racional. Mas o emprego dos fatores com elasticidades positivas não está situado no ponto ótimo econômico.

Tabela 13 - Valor do produto médio (VPMe $\mathrm{xi}_{\mathrm{i}}$ ), valor do produto marginal (VPMgxi), preços dos fatores $\left(\mathrm{Px}_{\mathrm{i}}\right)$ e relação entre os valores dos produtos marginais $\mathrm{e}$ os preços fatores $\left(\mathrm{VPMg}_{\mathrm{xi}} / \mathrm{Px}_{\mathrm{i}}\right)$, incluídos na função de produção de mamão, projeto Curu-Paraipaba, Estado do Ceará. Ano agrícola 1995/96.

\begin{tabular}{lrrrc}
\hline Fatores de produção & VPMexi & VPMgxi & Pxi & VPMgxi/Pxi \\
\hline Terra (ha) & 2480,87 & 530,66 & 390,00 & 1,36 \\
Mão-de-obra - (h/d) & 11,51 & 3,32 & 4,00 & 0,83 \\
Insumos básicos-R $\$$ & 4,20 & 1,80 & 1,09 & 1,65 \\
Capital-R $\$$ & 53,76 & $-27,95$ & 1,0534 & $-26,53$ \\
\hline
\end{tabular}

Fonte: Pesquisa direta.

Como a mão-de-obra é o fator relativamente menos escasso do pequeno produtor, talvez possa contribuir para que o fator esteja sendo utilizado além do necessário. A terra, com área de plantio diminutas, e insumos básicos, deveriam ter o seu uso incrementado, dado que os seus valores do produto marginal superam os respectivos preços. A falta de crédito formal ou informal é mais aguda no mamão que nas outras culturas aqui estudadas. Para o capital, a única solução para o seu uso racional no 
modelo de distribuição dágua vigente é promover a fiscalização e tentar reforçar acordo de cavalheiros no uso dos equipamentos de irrigação.

A Tabela 14 evidencia que para um dado volume da produção de mamão, existem condições de se determinar a taxa marginal de substituição (TMS) para cada par de fatores incluídos no modelo.

Tabela 14 - Taxa marginal de substituição entre os fatores (exceto água) incluídos na função de produção de mamão do projeto Curu-Paraipaba, Estado do Ceará, ano agrícola 1995-96.

\begin{tabular}{lrrcc}
\hline TMS xixj & $A C$ & $M O$ & $I B$ & $K$ \\
\hline AC & 1,00 & 0,00 & 0,00 & $-0,05$ \\
MO & 159,84 & 1,00 & 0,54 & $-8,41$ \\
IB & 294,81 & 1,84 & 1,00 & $-15,53$ \\
K & $-18,99$ & $-0,12$ & $-0,06$ & 1,00 \\
\hline
\end{tabular}

Fonte: Pesquisa direta.

Tomando-se por exemplo o valor da $T M S_{x 1 \times 2}$ (terra por trabalho), significa afirmar que, para cada ha de terra renunciado devem ser utilizadas 159,84 diárias, para manter o mesmo nível de produção no ponto da média geométrica observada da amostra. Comparando-se as $T M S_{x i x j}$ com as relações de preços, pode-se chegar à combinação entre os pares de fatores de custo mínimo. Se $T M S_{x i x j}>\mathrm{Pxj} / \mathrm{pxi}$, deve-se substituir Xi por $\mathrm{Xj}$, até o ponto de igualdade, já que esta taxa tende a cair na medida em que vão ocorrendo estas substituições. 
Uma inspeção na Tabela 12, mostra que as relações de preços em comparação com os dados da Tabela 14, permite afirmar que seria conveniente intensificar o uso de insumos por unidade de área.

5.2.1. A demanda de água para mamão

Se na eq. (62) os valores de, $\mathrm{AC}, \mathrm{MO}, \mathrm{IB}$ e $\mathrm{AG}$ forem substituídos por suas respectivas médias geométricas, AV e NP/ha por suas médias aritméticas, a produção de mamão $Y_{2}$ fica dependente apenas de AG (água), ou seja:

$$
Y_{2}=1,0305 \cdot(A G)^{0,2386}
$$

Multiplicando-se a eq. (63) por 71 , pode-se obter uma função de produção representativa da população que explora mamão no projeto, que fica:

$$
Y_{1 t}=73,16 \cdot(A G)^{0,2386}
$$

pode-se então determinar o PMg da água:

$$
\operatorname{PMg} A G=17,45 \cdot(\mathrm{AG})^{-0,7614}
$$

Multiplicando-se a equação (65) pelo preço da tonelada de mamão (R\$ 147,30), obtém-se o valor do produto marginal da água (VPMgAG) que no equilíbrio, é igual ao preço da água. Então, a função de demanda de curto prazo da água para a cultura do mamão pode ser assim expressa: 


$$
P_{A G}=2.571,54\left(\mathrm{AG}_{\mathrm{m}}\right)^{-0,7614}
$$

\subsection{Cultura da cana-de-açúcar (Etapa I)}

A Tabela 32 do apêndice 2 contém cinco equações resultantes dos ajustamento para estimar a função de produção representativa do produtor de cana-de-açúcar na etapa I do projeto Curu-Paraipaba. A equação selecionada foi a de número I. A produção de cana-de-açúcar, expressa em toneladas é a variável dependente, e as independentes são as seguintes: área cultivada em hectares ( $\mathrm{AC})$, trabalho humano $(\mathrm{MO})$, valor dos insumos básicos (IB), valor do capital na forma de materiais e equipamentos de irrigação $(\mathrm{K})$ e água $(\mathrm{AG})$.

A variável relevante que afeta indiretamente a produção é de natureza eminentemente tecnológica e representada pela intensidade de uso da água (AG/ha), expressa $\mathrm{em} \mathrm{mil} \mathrm{m}^{3}$ por hectare. Quanto maior for a intensidade de uso da água, menor será a sua elasticidade parcial de produção. Esta interação é determinada pelo produto da variável $\mathrm{AG}$ ha com o logaritmo de $\mathrm{AG}$.

A cana-de-açúcar sempre foi a cultura predominante em todo o perímetro irrigado. Segundo Oliveira (1994), a cana participava com $84 \%$ da renda bruta do perímetro em 1989. As atividades econômicas tiveram inicio na etapa I em 1974 e a primeira safra obtida em 1977 apresentou um rendimento de 104 ton/ha. (Oliveira, 1994). A autora afirma que "a fase boa de produtividade verificou-se entre 1977 e 1980 quando a energia era barata e o solo era adubado com regularidade". Em 1987, dez anos após a obtenção da primeira safra, o rendimento havia caído para 53 ton/ha. Os dados levantados na amostra indicam que, no ano agrícola de 1995/96, o rendimento da canade-açúcar em todo o projeto foi de 44,26 ton/ha.

A variável intensidade de uso da água está especificada em diversas posições (ver a Tabela 32, apêndice 2). Mostra o modelo selecionado I que considera a variável 
água/ha (AG/ha) na forma quadrática isoladamente, ao lado de outros modelos com esta apenas na forma linear e simultaneamente nas duas formas. Considera, também, a influência da assistência técnica na forma Cobb-Douglas tradicional, que tem elasticidade constante.

A competitividade por água na etapa I é muito elevada, com o desvio padrão da quantidade de água /ha igual a $4,24 \mathrm{mil} \mathrm{m}^{3} / \mathrm{ha}$. A menor intensidade de uso observada foi de $1,735 \mathrm{mil} \mathrm{m}^{3} / \mathrm{ha}$. Vinte por cento dos produtores incluídos na amostra utilizaram mais de $10 \mathrm{mil} \mathrm{m}^{3} /$ ha de água e um deles utilizou $19,883 \mathrm{mil} \mathrm{m}^{3} / \mathrm{ha}$, superando em quase $2 \mathrm{mil} \mathrm{m}^{3} /$ ha o limite estabelecido pelo DNOCS.

Comparando-se a equação I selecionada com a equação II que considera a intensidade de uso da água na forma linear, verifica-se duas diferenças marcantes. Nesta, a elasticidade parcial de produção da água é muito alta e o uso da terra encontra-se no estágio III de produção, embora o coeficiente da terra não seja significativo. Mesmo que a quantidade média de terra utilizada por produtor na cana-de-açúcar seja a mais alta (1,5 ha) dentre as culturas estudadas, acredita-se que não existe excesso de uso da terra em relação aos demais fatores. Estas duas constatações não encontram explicação lógica dentro do sistema de produção vigente. Na equação selecionada I, o coeficiente do fator terra é significativo ao nível de $26 \%$, mas o valor do coeficiente supera ao do seu erro padrão. Esta variável apresenta alta correlação, de certa forma esperada, com a mão-deobra $(0,79)$ e com insumos $(0,78)$ (ver a Tabela 38 , apêndice 3 ).

Mas o cálculo do condition number utilizando-se os eingenvalue $(\lambda)$ obtidos da matriz X’X na análise de colinearidade para a cultura da cana-de-açúcar na etapa I, resulta em um valor igual a 4,35 que, conforme já mencionado, não sugerem preocupantes problemas de multicolinearidade (ver Tabela 35, apêndice 3). Também não se pode rejeitar a hipótese $H_{0}$ de que os erros da regressão do mamão sejam homocedásticos, conforme o teste de Glejser (ver Tabela 34, apêndice 3). 
A equação IV do apêndice 8 incluiu a variável assistência técnica, cujo parâmetro não é significativo, indicando que não existe influência desta variável sobre a produção.

O modelo I foi selecionado não porque apresenta o melhor ajustamento em relação aos demais. Embora o coeficiente de determinação seja considerado bom $(83,15 \%)$, é o menor entre todos os apresentados. Contempla todas as variáveis relevantes e os coeficientes dos fatores terra, capital e água são significativos, respectivamente a $26 \%, 15 \%$ e $18 \%$. Mas, os valores dos coeficientes são todos superiores aos respectivos erros padrões de estimativas. Todos os sinais dos coeficientes possuem explicação plausível.

O capital por exemplo, apresenta valor do coeficiente negativo, embora seja um fator relativamente escasso pelas restrições ao crédito, o que seria uma aparente contradição. Este problema também foi detectado e já comentado na análise da cultura do mamão. O sistema de distribuição dágua entre usuários, pela falta de medidores, obedece a vários critérios. Estes vão desde períodos oficiais de irrigação preestabelecidos e acordos de cavalheiros até o uso de métodos fraudulentos. Negociação de quotas de água entre irrigantes deve ocorrer, embora não tenha sido objeto de investigação nem identificado nesta pesquisa.

Os coeficientes de regressão significativos em graus de probabilidades muito baixos foram mantidos no modelo dada a sua importância no processo produtivo.

Segundo Heady \& Dillon (1972, p.269), não é recomendável nestes casos a exclusão de variáveis cujos coeficientes não sejam altamente significativos. O teste de significância, segundo os autores, mede a força com que é rejeitada a pior hipótese. A aceitação de que $\beta_{\mathrm{ac}} \beta_{\mathrm{k}}$ e $\beta_{\mathrm{ag}}$ sejam diferentes de zero com maior probabilidade, poderá ser confirmada em outras circunstâncias, em futuras pesquisas.

O modelo selecionado I (Ulveling e Fletcher) é claramente superior, do ponto de vista estatístico, ao modelo testado IV do tipo Cobb-Douglas tradicional. A realidade mostra que a média de consumo dágua na etapa I é muito baixa. Os dados da amostra 
indicam que os irrigantes da etapa I utilizam em média, $9,94 \mathrm{mil} \mathrm{m}^{3} / \mathrm{ha}$, enquanto os da

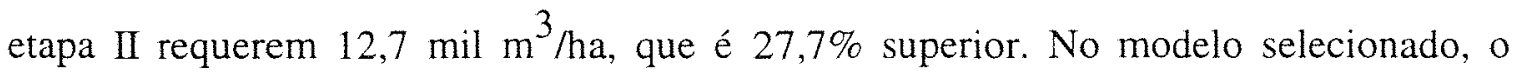
coeficiente da variável AG/ha é negativo e encontra-se na forma quadrática.

Alguns produtores afirmaram não utilizar nenhum insumo na cana-de-açúcar no ano agrícola 1995/96. São produtores independentes, que não possuem nenhum vínculo com a usina AGROVALE e não dispõem de nenhuma forma de crédito. Foram seis casos (20\% da amostra) em que a variável zero foi substituída por 1, a exemplo do que ocorreu com a cultura do coco.

O modelo selecionado para a função de produção de cana-de-açúcar na etapa I, tem a seguinte forma algébrica:

$$
Y=2,275 \cdot A G^{0.31} \cdot M O^{0,357} \cdot I B^{0,0518} K^{-0,1507} A G^{0.2569-0.00047(A G / h))^{2}}
$$

A elasticidade total de produção é de 0,8 o que significa retornos decrescentes de escala. Um incremento simultâneo em terra, trabalho, e, água e insumos básicos concorre para que o acréscimo da quantidade de cana-de-açúcar obtido em resposta aos incrementos seja menos do que proporcional aos verificados nas quantidades empregadas daqueles fatores. Políticas que favorecessem o incremento simultâneo de todos os fatores não seriam recomendáveis. O uso indevido do capital certamente contribui para a baixa eficiência no uso dos fatores. Neste caso, rendimentos decrescentes não sugerem uso excessivo de fatores e sim, o procedimento dos produtores já comentado.

As elasticidades parciais de produção de $\mathrm{AC}, \mathrm{MO}, \mathrm{IB}$ e $\mathrm{K}$ são constantes, enquanto que a da água $A G$ depende da intensidade de seu uso. Fixando-se as quantidades de água por hectare nos seus valores mínimo, médio e máximo, obtém-se as seguintes elasticidades parciais de produção da água: 
AG/ha mínimo; $1,735 \mathrm{~m}^{3} \Rightarrow \mathrm{EAG}=0,2555$

AG/ha médio; $7,021 \mathrm{~m}^{3} \Rightarrow \mathrm{EAG}=0,2344$

AG/ha máximo; $19,883 \mathrm{~m}^{3} \Rightarrow \mathrm{EAG}=0,0762$.

Na medida em que, a partir do nível mínimo de uso da água (1,735 mil $\mathrm{m}^{3} / \mathrm{ha}$ ), a intensidade de seu uso vai aumentando, a elasticidade de AG diminui. Isto é coerente com a lei dos rendimentos decrescentes. No grau de intensidade médio $(7,021$ mil $\mathrm{m}^{3} /$ ha), a elasticidade é igual a 0,2344 , enquanto que na máxima, atinge o valor de 0,0762. A quantidade limite de uso da água que, se ultrapassada, faz com que o produtor saia do estágio racional de produção é de $23.709 \mathrm{~m}^{3} /$ ha.

Os fatores mais importantes quanto a área cultivada são pela ordem ara a cultura são em ordem de importância, trabalho, terra e água, exatamente os que menos dependem do crédito rural.

Uma inspeção na Tabela 15 mostra que as relações VPMgx1/Pxi permitem concluir que terra e insumos poderiam ter seu uso reduzido, talvez decorrente do crédito informal fomentado pela usina, fato não verificado nas outras culturas. O trabalho deveria ser utilizado em maior intensidade. A diferença entre a cultura da cana com as demais estudadas é que, naquela, toda a produção é adquirida por um único comprador, a usina AGROVALE. Apenas aqueles produtores que não estavam comprometidos em vender sua produção para usina tinham limitações no uso de insumos.

Interessada na matéria-prima para sua produção de álcool e açúcar, a usina fazia, no ano agrícola de 1995/96, o fomento de insumos e serviços básicos de apoio aos produtores. Com a crise do setor sucro-alcooleiro no País e Região, o suporte da usina aos produtores vinha diminuindo ano a ano. Mesmo assim, a expressividade da cultura da cana-de-açúcar no projeto, quanto à área cultivada, deve-se em parte ao serviço usual de crédito informal, inexistente nas demais explorações. 
Tabela 15 - Valor do produto médio (VPMe $\mathrm{xi}_{\mathrm{i}}$ ), valor do produto marginal (VPMg $\mathrm{xi}_{\mathrm{i}}$ ), preços dos fatores $\left(\mathrm{Px}_{\mathfrak{i}}\right)$ e relação entre os valores dos produtos marginais $\mathrm{e}$ os preços fatores $\left(\mathrm{VPMg}_{\mathrm{xi}} / \mathrm{Px}_{\mathbf{i}}\right)$, incluídos na função de produção de canade-açúcar (etapa 1), projeto Curu-Paraipaba, Estado do Ceará. Ano agrícola $1995 / 96$.

\begin{tabular}{lrrcc}
\hline Fatores de produção & VPMexi & VPMgxi & Pxi & VPMgxi/Pxi \\
\hline Terra (ha) & 788,42 & 244,41 & 390,00 & 0,63 \\
Mão-de-obra - (h/d) & 16,80 & 5,99 & 4,00 & 1,5 \\
Insumos básicos-R\$ & 5,09 & 0,26 & 1,09 & 0,24 \\
Capital - R\$ & 14,71 & $-0,22$ & 1,0534 & $-0,21$ \\
\hline
\end{tabular}

Fonte: Dados da pesquisa.

A Tabela 16 mostra a taxa marginal de substituição, cujo conceito foi apresentado anteriormente. Comparando-se estes números com os da Tabela 12, que contém as relações de preços dos fatores, pode-se identificar a combinação de custo mínimo entre um par de insumos para uma dada produção. Quando esta, por exemplo, for igual à média geométrica dos valores observados na amostra (43,13 ton), é conveniente aumentar a intensidade de uso do trabalho em relação ao de uso dos insumos por unidade de área. O trabalho adicional poderia ser destinado a uma mais efetiva fiscalização, para possibilitar o uso mais adequado do capital de irrigação, devido os incentivos para algumas pessoas tentarem levar vantagens quando não existem medidores. 
Tabela 16 - Taxa marginal de substituição entre os fatores (exceto água) incluídos na função de produção de cana-de-açúcar (etapa I) do projeto Curu-Paraipaba, Estado do Ceará, ano agrícola 1995-96.

\begin{tabular}{lrrrr}
\hline TMSxIX2 & $A C$ & $M O$ & $I B$ & $K$ \\
\hline AC & 1,00 & 0,02 & 0,00 & $-0,00$ \\
MO & 40,80 & 1,00 & 0,04 & $-0,04$ \\
IB & 940,04 & 23,04 & 1,00 & $-0,84$ \\
K & -1.110 .95 & $-27,23$ & $-1,18$ & 1,00 \\
\hline
\end{tabular}

Fonte : Dados da pesquisa

5.3.1. A demanda de água para cana-de-açúcar na etapa I

Se na eq. (67). os valores de $\mathrm{AC}, \mathrm{MO}, \mathrm{IB}$ e $\mathrm{K}$, forem substituídos por suas respectivas médias geométricas e o valor de AG/ha por sua média aritmética, a produção de cana-de-açúcar $Y_{3}$ fica dependente apenas de AG(água). Partindo da função de produção de cana-de-açúcar, tem-se:

$$
Y_{3}=7,0165 \cdot(A G)^{0,2334}
$$

Multiplicando-se a eq. (68) por 268, pode-se obter uma função de produção representativa da população que explora cana-de-açúcar (etapa I) no projeto, que fica:

$$
Y_{3 t}=1.880,42 \cdot(\mathrm{AG})^{0,2344}
$$

pode-se, então determinar o PMg da água: 


$$
\operatorname{PMg} A G=440,77 \cdot(A G)^{-0,7656}
$$

Multiplicando-se a equação (70) pelo preço da tonelada de cana-de-açúcar (R\$ 18,00), obtém-se o valor do produto marginal da água (VPMgAG) que, por definição, é igual ao preço da água. Então, a função de demanda da água para a cultura da cana-de-açúcar pode ser assim expressa:

$$
\mathrm{P}_{\mathrm{AG}}=7.933,87 \cdot\left(\mathrm{Ag}_{\mathrm{C} 1}\right)^{-0,7656}
$$

\subsection{Cultura da cana-de-açúcar (Etapa II)}

A função de produção selecionada para cana-de-açúcar na etapa II do projeto Curu-Paraipaba no ano agrícola 1995/96 corresponde ao modelo I (ver Tabela 33, apêndice 2). A produção de cana-de-açúcar expressa em toneladas é a variável dependente, e as independentes são as seguintes: área cultivada em hectares (AC), trabalho humano (MO), valor dos insumos básicos (IB), valor do capital na forma de materiais e equipamentos de irrigação (K) e água ( $A G)$.

Cerca de $78,1 \%$ das mudanças na produção de cana podem ser explicadas por estas variáveis.

No modelo escolhido, todos os parâmetros estimados são significativos a 5\% de probabilidade, exceto o fator terra com 10\%. Nas eq. II, III, IV da Tabela 33, foi incluída a variável espaçamento (distância entre sulcos). Foi a que melhor se ajustou, dentre o elenco de opções de variáveis com possível influência indireta sobre a produção. Nos modelos testados, esta variável foi especificada na sua forma linear, quadrática e combinada. Como se observa, a inclusão do espaçamento aumenta a 
variância do parâmetro referente ao valor de insumos básicos, que chega a ser negativo, conforme a eq. II. Como no modelo I, os parâmetros permanecem bem mais estáveis, optou-se por sua seleção e a conseqüente retirada do espaçamento, influenciando a elasticidade do valor dos insumos (IB). A correlação entre os termos linear e quadrático da variável espaçamento é muito alta $(0,97)$ (ver Tabela 39, apêndice 3). Verifica-se, também, que os fatores terra e capital são as únicas combinações altamente correlacionadas $(0,84)$, o que poderia trazer problemas de multicolinearidade. A eq. V considerou a variável assistência técnica (AT), que, do ponto de vista estatístico, não tem influência significativa sobre a produção.

A equação selecionada é do tipo Cobb-Douglas tradicional, ou seja, a elasticidade total é constante para todos os parâmetros. Apresenta-se melhor do ponto de vista estatístico do que os demais testados do tipo Ulveling-Fletcher. Possui menor coeficiente de determinação por envolver menor número de variáveis. Mas, o superior valor de "F" indica melhor ajustamento. A exemplo das outras culturas analisadas anteriormente, e seguindo os mesmos critérios do ponto de vista estatístico, a regressão feita com cana-de-açúcar na etapa II mostrou ausência de heterocedasticidade e de maiores problemas com multicolinearidade (ver Tabelas 34 e 35, apêndice 3).

O modelo apresenta duas particularidades que merecem ser apreciadas. A primeira revela a importância do fator capital na cana-de-açúcar na etapa II. Ao contrário dos produtos (cana-de-açúcar e mamão) analisados na etapa I, aqui, o capital tem grande influência sobre a produção. Sua qualidade é maior na etapa II e sua manutenção mais adequada. A fiscalização e controle devem ser mais efetivos e não há indícios do uso de métodos anti-éticos na irrigação. Isto pode percebido pela menor perda de água entre a fonte e o local da irrigação. Práticas destinadas a levar vantagens podem até ocorrer, mas devem ser pouco freqüentes. Embora o valor por hectare do capital na forma de equipamentos de irrigação da etapa II seja 5\% inferior à média usada na etapa I, a quantidade suprida de água é quase o dobro naquela etapa. Acredita-se que isto não ocorra apenas pela menor competitividade da água entre as culturas na etapa I. 
A segunda particularidade é que a elasticidade parcial da mão-de-obra apresenta sinal negativo. Aparentemente, o fator estaria sendo utilizado no estágio III da produção.

Esta etapa do projeto foi iniciada recentemente, a partir de 1993, e os dados da amostra indicam que existem, em média, 5,7 pessoas por família, cujo chefe tem, em média, 44,7 anos, enquanto os residentes da etapa I tem, em média, 49,3 anos. Isto significa uma força de trabalho um pouco mais jovem.

Oliveira (1994, p.78), a respeito da etapa II do projeto, afirma que "em razão do grande número de filhos dos irrigantes, ocorre um forte excedente de mão-de-obra". Sendo de implantação mais recente, haviam em 1995 apenas 7 linhas de exploração ${ }^{32}$ com alguma relevância e a cana-de-açúcar representava $76 \%$ da área cultivada em 1995/96 ${ }^{33}$. A etapa I, como visto, é bem mais diversificada. Conta com 18 linhas de exploração melhor distribuídas em termos de área cultivada. Na etapa II, existem poucas opções para distribuir sua força de trabalho mais jovem fora da cana-de-açúcar. Mesmo assim, não existem razões para se acreditar que esteja havendo sub-utilização de mão-deobra, embora esta suposição seja mais plausível do que se ocorresse com o capital de irrigação discutido anteriormente.

A razão fundamental, provavelmente, se deve a atividade monopsônica praticada pela usina AGROVALE.

Conforme afirmado no capítulo anterior, a usina adquiria quase toda a produção do projeto Curu-Paraipaba, principalmente na sua primeira etapa. Sua estratégia era fazer o fomento de crédito informal, fornecendo horas-máquinas, adubos, cana-semente, inclusive toda a operação de corte.

Os produtores da etapa II que não possuíam contrato de exclusividade de venda da cana para a usina, faziam o trabalho de corte, o que significava uso mais

\footnotetext{
32 Vide Tabela 3 do capítulo 4.

${ }^{33}$ Esta foi uma das principais razões da seleção apenas da cana-de-açúcar para o presente estudo na etapa II do projeto.
} 
intensivo deste fator em relação aos vinculados à usina. Além disso, por não receberem qualquer tipo de crédito, apresentam rendimentos inferiores.

Um exame dos dados amostrais, indicam que a quantidade média utilizada de trabalho humano na cana-de-açúcar é de 38 diárias por hectare, com uma produtividade média de 44 ton./ha. Isolando-se aqueles que empregam o fator trabalho acima do valor médio da amostra, constata-se o uso de 48 diárias por hectare, com um rendimento apenas de 37 ton/ha. Isto mostra que existe uma relação inversa entre mão-de-obra e produção, nas circunstâncias descritas acima.

O modelo selecionado tem a seguinte especificação:

$$
Y_{4}=1,869 \cdot A C^{0.5949} M O^{-0.5899} \cdot I B^{0.0819} K^{0.5627} \cdot A G^{0.3154}
$$

A elasticidade total de produção, já definida anteriormente é dada por $\left(\sum b_{i}=\right.$ $0,965)$, indicando praticamente rendimentos constantes à escala.

Comparando-se com a cana-de-açúcar na etapa $I$, que tem rendimentos decrescentes, na etapa II, os recursos são combinados com maior eficiência embora haja uma relação inversa captada pelo modelo, entre trabalho humano e produção.

Os valores do produto médio são superiores aos do produto marginal de cada fator, além de todos serem positivos, com exceção da mão-de-obra, conforme pode ser verificado na Tabela 17 . Um detalhe importante é que na etapa II o coeficiente da mãode-obra tem sinal negativo enquanto o capital na forma de equipamento de irrigação é positivo. É exatamente o contrário do que ocorre com a cana-de-açúcar na etapa I. As razões foram explicitadas anteriormente. Os fatores terra e insumos básicos estão próximos do emprego no ponto ótimo econômico. 
Tabela 17 - Valor do produto médio (VPMe $\mathrm{xi}_{\mathrm{i}}$ ), valor do produto marginal (VPMg $\mathrm{xi}_{\mathrm{Xi}}$ ), preços dos fatores $\left(\mathrm{Px}_{\mathrm{i}}\right)$ e relação entre os valores dos produtos marginais e os preços dos fatores (VPMgxi $/ \mathrm{Px}_{\mathrm{i}}$ ), incluídos na função de produção de cana-de-açúcar (etapa II), projeto Curu-Paraipaba, Estado do Ceará. Ano agrícola 1995/96.

\begin{tabular}{lcccc}
\hline Fatores de produção & VPMexi & VPMgxi & Pxi & VPMgxiPxi \\
\hline Terra (ha) & 649,91 & 384,96 & 390,00 & 0,99 \\
Mão-de-obra - (h/d) & 22,46 & $-13,25$ & 4,00 & $-3,31$ \\
Insumos básicos-RS & 15,33 & 1,24 & 1,09 & 1,13 \\
Capital - RS & 23,11 & 11,56 & 1,0534 & 12,57 \\
\hline
\end{tabular}

Fonte: Dados da pesquisa.

Mantendo-se inalterada a produção de cana em torno de sua média geométrica, pode-se obter a taxa marginal de substituição entre os fatores analisados, conforme a Tabela 18.

Tabela 18 - Taxa marginal de substituição entre os fatores (exceto água) incluídos na função de produção de cana-de-açúcar (etapa II) do projeto Curu-Paraipaba, Estado do Ceará, ano agrícola 1995-96.

\begin{tabular}{lcccc}
\hline TMS $1 \times 2$ & $A C$ & $M O$ & $I B$ & $K$ \\
\hline AC & 1,00 & $-0,03$ & 0,00 & 0,03 \\
MO & $-29,05$ & 1,00 & $-0,09$ & $-0,87$ \\
IB & 310,45 & $-10,68$ & 1,00 & 9,32 \\
K & 33,30 & $-1,15$ & 0,11 & 1,00 \\
\hline
\end{tabular}

Fonte: Dados da pesquisa. 
O valor de $\mathrm{R} \$ 310,45$ da Tabela 18 significa, por exemplo, que a redução de 1 ha de terra acompanhado pelo aumento de $\mathrm{R} \$ 310,45$ em insumos básicos, manteria a produção de cana-de-açúcar inalterada em torno de sua média geométrica $(64,82$ ton) por produtor. Isto é interessante economicamente, quando é necessário substituir fatores mais caros por fatores mais baratos, já que a produção não se altera. A relação de preços entre os fatores é quem orienta esta substituição. Comparando-se os números da Tabela 18 com os da Tabela 12, sempre que $T M S_{x i x j}>\mathrm{Pxj} / \mathrm{pxi}$, deve-se substituir $\mathrm{X}_{\mathrm{i}}$ por $\mathrm{X}_{\mathrm{j}}$ Nesse caso, aparentemente seria interessante aumentar a intensidade de capital $(K)$ e diminuir a de trabalho (MO) por unidade de área cultivada. Substituindo-se mão-deobra, dentro de certos limites, por qualquer outro fator, ocorreria melhor combinação, do ponto de vista econômico, dos recursos empregados na cultura da cana-de-açúcar na etapa II.

5.4.1. A demanda de água para cana-de-açúcar na etapa II

Se na eq.(72) os valores de $A C, M O, I B$ e $K$ forem substituídos por suas respectivas médias geométricas, tem-se:

$$
Y_{4}=2,9562 \cdot(A G)^{0,3154}
$$

Multiplicando-se a eq. (73) por 158, pode-se obter uma função de produção representativa da população que explora cana-de-açúcar (etapa II) no projeto, que fica:

$$
Y_{4 t}=467,07 \cdot(A G)^{0,3154}
$$


pode-se, então, determinar o PMg da água:

$$
\text { PMgAG }=147,31 \cdot(\mathrm{AG})^{-0,6846}
$$

Multiplicando-se a equação (75) pelo preço da tonelada de cana-de-açúcar (R\$ 18,00), obtém-se o valor do produto marginal da água (VPMgAG) que, por definição, é igual ao preço da água. Então, a função de demanda da água para a cultura da cana-de-açúcar na etapa II, pode ser assim expressa:

$$
P_{A G}=2 \cdot 651,7 \cdot\left(A_{c 2}\right)^{-0,6846}
$$

5.5. A Oferta dágua para as Culturas em Estudo.

Os critérios gerais de distribuição dágua para irrigação pública no Ceará, obedecem às peculiaridades de cada perímetro, razão das diferenças nos procedimentos operacionais. No caso específico do Curu-Paraipaba, as informações básicas são obtidas com dois ou três meses de antecedência do início das liberações da água, que, normalmente, ocorrem no mês de julho de cada ano. A COGERH e o DNOCS através dos comitês de bacias, promovem reuniões com instituições oficiais, representantes de irrigantes privados e de projetos de irrigação pública, e de usuários de todas as cidades e vilas do vale do Curu, para levantar as necessidades de água. Confrontando estes dados com as disponibilidades nos reservatórios, dos recursos disponíveis para cobrir os custos variáveis de suprimento (principalmente energia elétrica), é elaborado o programa de liberações dágua para o período seguinte.

Dentro das circunstâncias descritas, a Tabela 19 mostra que foram bombeados 14.931,3 mil $\mathrm{m}^{3}$ de água para o projeto Curu-Paraipaba no período de julho de 1995 a 
fevereiro de 1996. A etapa I recebeu $64,3 \%$ da água total distribuída e os gastos com energia elétrica nas duas etapas totalizaram $\mathrm{R} \$ 366.066,72$ no período.

Tabela 19 - Quantidade de água fornecida e despesas com energia elétrica por etapa, no perímetro Curu-Paraipaba, Estado do Ceará, período de julho/95 a fev/96.

\begin{tabular}{lccc}
\hline Suprimento & Ágla-mil $M^{3}(1)$ & Energia-R\$(2) & Energia-R\$/mil/m $\mathrm{m}^{2}$ \\
\hline Etapa I & $9.596,6$ & $241.151,20$ & 25,13 \\
Etapa II & $5.334,7$ & $124.915,52$ & 23,42 \\
\hline Total & $14.931,3$ & $366.066,72$ & 24,52 \\
\hline
\end{tabular}

Fonte: (1) DNOCS; (2) Cooperativa dos irrigantes do projeto Curu-Paraipaba.

Foram irrigados no ano agrícola 1994/95 (época do cadastro) 2.141 ha, o que representou um gasto de quase $7 \mathrm{mil} \mathrm{m}^{3}$ por hectare ${ }^{34}$. A área total cultivada compreendia 300 ha de forrageiras, 412 ha de culturas permanentes ainda em formação e 558 ha de uma miscelânea de culturas isoladas menos relevantes e diversos tipos de consórcio, além dos 871 ha ocupados pelas culturas em estudo. Estas, tiveram um crescimento de 5,28 \% na área cultivada (917 ha) no ano agrícola 1995/96, segundo os dados amostrais projetados para a população, sendo: 178 ha de coco, 52 ha de mamão, 400 ha de cana-de-açúcar na etapa I e 287 ha de cana-de-açúcar na etapa e II.

A Tabela 20 mostra informações de duas naturezas: a primeira refere-se às quantidades previstas de água e de gastos com energia elétrica segundo os critérios preestabelecidos pelo DNOCS e pela COGERH, já mencionados. Neste caso, a água a ser destinada para as culturas em estudo deveria representar 40,9\% do total disponível.

\footnotetext{
${ }^{34}$ No projeto Curu-Recuperação, situado no mesmo Vale, a água é distribuída por gravidade. Como o custo de energia elétrica é zero, havendo disponibilidade nos reservatórios, a quantidade distribuída fica próxima do limite de $18 \mathrm{mil} \mathrm{m}^{3} / \mathrm{ha}$ e a tarifa da água é de apenas $\mathrm{R} \$ 3,06 / \mathrm{mil} \mathrm{m}^{3}$ (apêndice 8 ).
} 
Tabela 20 - Quantidades de água e despesas com energia elétrica previstas e efetivas nas culturas selecionadas para estudo, no projeto Curu-Paraipaba, Estado do Ceará, ano agrícola de 1995/96.

\begin{tabular}{lcccc}
\hline Suprimento & \multicolumn{2}{c}{ Água-mil-m } & \multicolumn{2}{c}{ Energia-Elétrica-R\$ } \\
\hline Situação $\Rightarrow$ & Prevista (1) & Efetiva (2) & Prevista (1) & Efetiva (2) \\
Etapa I & & & & \\
Coco & $1.098,9$ & $1.489,2$ & $27.604,40$ & $37.408,70$ \\
Mamão & 415,7 & 636,4 & $10.442,40$ & $15.976,30$ \\
Cana-de-açúcar & $2,479,7$ & $2.664,7$ & $62.290,00$ & $66.963,91$ \\
Sub-total 1 & $3.994,3$ & $4.790,3$ & $100.336,80$ & $120.348,91$ \\
Etapa II & & & & $81.838,80$ \\
Cana-de-açúcar & $2.108,9$ & $3.494,1$ & $49.390,40$ & $81.838,80$ \\
Sub-total 2 & $2.108,9$ & $3.494,1$ & $49.390,40$ & $202.187,71$ \\
\hline Total & $6.103,2$ & $8.284,4$ & $149.727,20$ & \\
\hline
\end{tabular}

Fonte: (1) DNOCS; (2) Dados da pesquisa.

$\mathrm{Na}$ verdade, são estimativas de interesse meramente programático dado que os órgãos se interessam mais com o volume total de água a ser liberado para o projeto e menos com a distribuição para as culturas. A falta de medidores impossibilita o controle por produtor e, consequientemente, por cultura. Os valores efetivos da Tabela 20 foram estimados através dos dados de consumo obtidos na amostra e projetados para a população, permitindo, da mesma forma, também estimar os gastos com energia. A utilização efetiva de água, representou $55,5 \%$, ou seja, $14,6 \%$ superior à prevista.

No exame da Tabela 20, verifica-se que os produtores seguem uma orientação diferente na distribuição da água entre os seus cultivos, quando esta é comparada com a 
que segue o critério de área cultivada orientada pelo DNOCS/COGERH. Na etapa I, a quantidade dágua é incrementada em 20\%. Para o mamão, há um acréscimo de 53\%, para o coco utiliza-se $35 \%$ a mais, e para a cana-de-açúcar, 7,5\%. Na etapa II o incremento supera $65 \%$, talvez em razão da menor competitividade entre a cana-deaçúcar com outras linhas de exploração. Ademais, nesta etapa, existe um sistema de bombeamento e distribuição mais moderno, eficiente e menos congestionado que na etapa I.

O importante é assinalar que, mesmo no sistema tarifário e distributivo prevalecente, sem o controle de uso individual por falta de medidores, o irrigante busca alocar a água que chega às culturas de maior valor econômico. O suprimento efetivo de água no ano agrícola de 1995/96 foi de $14.931,3 \mathrm{mil} \mathrm{m}^{3}$ (mostrado na Tabela 19) e as culturas registradas na Tabela 20 absorveram $14,6 \%$ além do previsto. Isto significa que as demais culturas tiveram sua parcela de água reduzida para a irrigação.

A quantidade dágua ministrada às culturas em estudo foi de $8.284,4 \mathrm{mil} \mathrm{m}^{3}$, com base nos dados amostrais. Este volume será uma importante referência para toda a análise a ser feita neste trabalho a seguir.

5.6. O Preço da Água

Para determinar os preços da água, inicialmente, fez-se uma simulação, utilizando-se as equações do VPMgag para distintos preços dos produtos observados em Paraipaba-Ce, no período de julho de 1994 até março de 1998. Assim, tomou-se os preços médios mensais de todo o período e as médias mensais máximas e mínimas de cada ano, dos preços recebidos pelos produtores de coco, cana-de-açúcar e mamão. O preço da água seria de $\mathrm{R} \$ 153,93 / \mathrm{mil}^{3}$ se tivessem prevalecido os preços médios mensais dos produtos. Se os produtores tivessem recebido os preços máximos ou 
mínimos registrados na Tabela 40 do apêndice 5, os preços da água seriam respectivamente $\mathrm{R} \$ 187,00 / \mathrm{mil} \mathrm{m}^{3}$ e $\mathrm{R} \$ 124,83 / \mathrm{mil} \mathrm{m}^{3}$.

Para não tornar este estudo repetitivo, a aplicação metodológica que se segue, bem como toda a análise decorrente, serão feitas segundo os preços observados pelos produtores no ano agrícola da pesquisa (1995/96).

Sejam as equações (61), (66), (71) e (76) já estimadas e que representam as demandas totais de água para cada cultura:

$$
\begin{aligned}
& \mathrm{P}=14 \cdot 091,42 \cdot(\mathrm{AG})_{\mathrm{c}}{ }^{-0,7514} \\
& \mathrm{P}=2 \cdot 571,54 \cdot(\mathrm{AG})_{\mathrm{m}}{ }^{-0,7614} \\
& \mathrm{P}=7 \cdot 933,87 \cdot(\mathrm{AG})_{\mathrm{Cl}}{ }^{-0,7656} \\
& \mathrm{P}=2 \cdot 651,7 \cdot(\mathrm{AG})_{\mathrm{C} 2}{ }^{-0,6846},
\end{aligned}
$$

onde $\mathrm{P}$ é o preço da água e $(\mathrm{AG})_{\mathrm{c}},(\mathrm{AG})_{\mathrm{m}},(\mathrm{AG})_{\mathrm{cl}}$ e $\left(\mathrm{AG} \mathrm{K}_{2}\right.$ são, respectivamente, as quantidades a serem alocadas de água para as culturas do coco, mamão e cana-de-açúcar para as etapas I e II do projeto Curu-Paraipaba. Estas 5 incógnitas pertencem a um sistema de quatro equações e para serem estimadas requerem a identidade representada pela oferta fixa de água, onde $\Sigma A G_{i}=8.284,4 \mathrm{mil} \mathrm{m}^{3}$, conforme Tabela 20.

O preço de equilíbrio desse sistema de equações é igual a $\mathrm{R} \$ 140,61$ por mil $\mathrm{m}^{3}$. O apêndice 5 mostra como o sistema de equações foi resolvido.

Substituindo o preço calculado nas equações de demandas totais de água, obtém-se as quantidades de água a serem alocadas em cada cultura. Estas podem ser comparadas com o uso efetivo, conforme pode ser observado na Tabela 21. 
Tabela 21 - Distribuição da água por cultura e etapa, segundo o critério de preço e pelo sistema prevalecente no projeto Curu-Paraipaba, ano agrícola 1995/96.

\begin{tabular}{|c|c|c|c|c|c|c|}
\hline Culturas & $\begin{array}{l}\text { Alocação racional } \\
\text { mil m}^{3} \text { (1) }\end{array}$ & $\%$ & $\begin{array}{l}\text { Alocação efetiva } \\
\text { mil m }^{3}(2)\end{array}$ & $\%$ & $\begin{array}{l}\text { "superávit } \\
\text { mil m" }\end{array}$ & $\begin{array}{l}\text { "deficit" } \\
\text { mil m }\end{array}$ \\
\hline Coco & $4.521,1$ & 54,57 & $1.489,4$ & 17,98 & -- & $3.031,7$ \\
\hline Mamão & 396,2 & 4,78 & 636,4 & 7,68 & 240,2 & --- \\
\hline $\begin{array}{l}\text { Cana-de- } \\
\text { açúcar (et.I) }\end{array}$ & $1.608,3$ & 19,42 & $2.664,6$ & 32,16 & $1.056,3$ & $-\cdots$ \\
\hline $\begin{array}{l}\text { Cana-de- } \\
\text { açúcar (et.II) }\end{array}$ & $1.758,9$ & 21,23 & $3.494,1$ & 42,18 & $1.735,2$ & --. \\
\hline Total & $8.284,5$ & 100 & $8.284,5$ & 100 & $3.031,7$ & $3.031,7$ \\
\hline
\end{tabular}

Fonte: (1) Resultados da pesquisa; (2) DNOCS.

A Tabela 21 indica que a cultura do coco consome apenas $18 \%$ da água total disponível às culturas em estudo, quando deveria utilizar $54,6 \%$ se a distribuição fosse fundamentada na disposição marginal a pagar. Com o alto subsídio verificado no preço da água, todos os produtores têm acesso ao fator, sejam eficientes ou ineficientes no seu uso. Ressalte-se que este deficit não se deve apenas ao baixo preço cobrado. Os problemas de distribuição são também decorrentes da não exclusividade de uso.

A quantidade adicional de água para o coco deveria ser oriunda das demais culturas que a receberam em excesso. Pelo volume efetivo, os produtores de coco estariam dispostos a pagar $\mathrm{R} \$ 324,00 / \mathrm{mil} \mathrm{m}^{3}$. Este preço pode ser facilmente determinado, substituindo-se na eq. 61 a quantidade de água efetivamente alocada para o coco. É a cultura que atribui o mais alto valor pela água em relação às demais estudadas.

A cultura do mamão deveria utilizar somente $62,2 \%$ da água que foi efetivamente absorvida nas circunstâncias prevalecentes no ano agrícola de 1995/96. Mantida a mesma quantidade de água neste ano os produtores estariam dispostos a pagar $\mathrm{R} \$ 98,00 / \mathrm{mil} \mathrm{m}^{3}$ de água. Ao preço de equilíbrio de $\mathrm{R} \$ 140,61 / \mathrm{mil} \mathrm{m}^{3}$, haveria uma 
renúncia de $240,2 \mathrm{mil} \mathrm{m}^{3}$ de água. A cana-de-açúcar, explorada nas etapas I e II, pagaria respectivamente, $\mathrm{R} \$ 77,60$ e $\mathrm{R} \$ 87,90$ por mil $\mathrm{m}^{3}$ nas duas etapas pelo consumo de água nas quantidades utilizadas no ano 95/96. Em suma, a cultura do coco atribui um maior valor a água e a cana-de-açúcar, o menor valor.

O modelo proposto recompensa com maiores volumes de água as culturas de maior valor e que são cultivadas relativamente com um grau tecnológico superior. Isto pode ser medido através do valor do produto marginal, que depende do preço do produto e da função de produção, que descreve algebricamente a tecnologia.

Assim, quando a política tarifária é negligente do ponto de vista econômico e agronômico, as perdas são muito grandes. Isto pode ser medido pelo uso de grande quantidade dágua em atividades de baixo valor. Pode-se afirmar pela análise da Tabela 21, que o tamanho do desperdício é de 3,031 milhões de $\mathrm{m}^{3}$ dágua, o que representa mais de um terço $(36,6 \%)$ de toda a água ministrada às culturas em estudo. Esta seria a quantidade que a cultura do coco poderia adquirir, pagando o preço de equilíbrio igual a $\mathrm{R} \$ 140,61$ por mil $\mathrm{m}^{3}$ de água.

A Tabela 21 também indica que a distribuição da água entre os setores do projeto apresenta grande diferença quando comparados o modelo tarifário proposto com o sistema de distribuição vigente. Nesta situação, estão sendo captados pela etapa II do projeto $42,18 \%$ de toda a água utilizada, quando deveriam ser alocados apenas $21,2 \%$, ou seja, a metade da água que recebeu no ano 95/96.

As curvas das demandas indicam que a quantidade demandada de água cresce se o seu preço diminuir. No limite, se a água é de graça, o ponto de uso racional de água é aquele que maximiza a produção física de cada cultura.

A demanda por água destinada à irrigação nas culturas estudadas é elástica. Uma diminuição no preço faz com que a quantidade demandada aumente em um percentual proporcionalmente maior do que a correspondente diminuição de preço. As elasticidades preço da demanda de água para as culturas do coco, mamão e cana-deaçúcar nas etapas I e II são respectivamente -1,3308; -1,3134; -1,3062 e -1,4607. Alta 
elasticidade preço da demanda significa potencial de substituição de uso da água. Equipamentos que permitissem irrigação por gotejamento seriam uma forma de substituir água por capital, até um certo ponto. Variedades de plantas menos exigentes por água poderiam ser utilizadas, horários noturnos ou com menor insolação para irrigar, reduzindo perdas por evaporação, constituem alguns exemplos relevantes de manejo. Esses métodos de substituição de água, indicam que existe um grande espaço para o uso de tecnologias poupadoras. Para outras destinações, como por exemplo, uso humano, onde a água é imprescindível e não existem substitutos, a demanda tende a ser inelástica. Em estudos sobre demanda de água de melhor qualidade para consumo humano no meio rural de vários países, Briscoe (1990, p. 52) encontrou as elasticidades preço de $-0,15$ no Brasil, $-0,14$ na Índia, $-0,07$ no Zimbabwe e $-0,06$ no Quênia.

As estimativas de elasticidades preço da demanda dágua encontram-se detalhadas no apêndice 6. São valores muito próximos. Por exemplo, uma redução de 1 \% no preço da água destinada à irrigação do coco e do mamão iria aumentar sua quantidade demandada em respectivamente $1,33 \%$ e 1,31\%. Para a cana-de-açúcar nas etapas I e II, idêntica redução de preço aumentariam as quantidades demandadas em 1,3 $\%$ e $1,46 \%$. Como são grandezas adimensionais, as elasticidades podem ser comparadas. Dentre as culturas estudadas, a menor elasticidade estimada foi a da cana-de-açúcar na etapa II, e a maior, da cana-de-açúcar na etapa I. Isto se deve, talvez, ao fato desta etapa ser mais diversificada e oferecer mais opções de uso da irrigação.

O apêndice 6 indica que, no caso particular deste estudo, as elasticidades calculadas são constantes. Isto significa que as funções de demanda aqui analisadas são do tipo hipérbole equilátera generalizada (Weber, 1977 p.84). Outras propriedades importantes deste tipo de função é que o seu centro está na origem, sendo também assintótica aos eixos coordenados. 


\subsection{Disposição a Pagar por Água}

Segundo Leithold (1988, p.422), uma hipérbole equilátera generalizada é definida quando o integrando tem uma descontinuidade infinita no limite inferior da integração. Trata-se de uma integral imprópria. O apêndice 7 demonstra como foi feito o cálculo das áreas abaixo das curvas da demanda de água por cultura no intervalo que vai de zero até as quantidades de água sugeridas pelo modelo.

A área situada abaixo da curva da demanda equivale ao valor bruto da produção (VBP), registrado por cultura na coluna 1 da Tabela 22. Estes valores também podem ser obtidos substituindo-se, nas funções de produção que originaram a curva da demanda, as quantidades de água recomendadas pelo modelo de distribuição proposto. Basta multiplicar o produto obtido pelo seu preço.

Na segunda coluna desta Tabela 22, consta o VBP obtido de cada cultura estudada, estimado a partir dos dados amostrais ${ }^{35}$ de produção devidamente projetados para a população e multiplicados pelo preço. O mesmo procedimento foi adotado para estimar a remuneração dos fatores fixos, só que utilizando-se os preços e quantidades de todos fatores incluídos nas funções de produção e mantidos fixos.

Existe portanto, o VBP proposto, obtido pelo modelo e o VBP obtido, estimado a partir dos dados amostrais. Nas colunas 4 e 5 da Tabela 22, apresenta-se a DAP* por água do modelo proposto. Esta foi definida como sendo a diferença entre o VBP (área sob a curva da demanda) e a remuneração dos fatores fixos ${ }^{36}$. No modelo efetivo adota-se o mesmo critério, ou seja, a DAP* por água efetivamente é igual a diferença entre o VBP obtido e a remuneração dos mesmos fatores fixos.

Os resultados esclarecem que, o modelo proposto de distribuição de água acarreta um aumento do VBP nas culturas estudadas, em 243,8 \% em relação ao modelo

35 Segundo o cadastro da COGERH, o VBP observado de todas as áreas exploradas com as culturas estudadas na safra agrícola $1994 / 95$ foi igual a R $\$ 1.390,9$ mil.

${ }^{36}$ Este conceito foi apresentado detalhadamente no modelo teórico, capítulo 4. 
prevalecente. Em termos absolutos, os produtores das culturas estudadas aumentariam o VBP em R\$ 3,22 milhões ${ }^{37}$ no ano agrícola deste estudo. O VBP do coco quase quadruplica. A DAP* por água no modelo proposto é 7,15 vezes superior a do efetivamente obtido.

No sistema de produção atual, a cultura do coco é a base de sustentação econômica do projeto, sendo a única capaz de cobrir, com folga, o principal item de custo de suprimento de água, que é o de energia elétrica. Isto talvez possa explicar o crescimento que a cultura vem experimentando nos últimos anos. A cultura do mamão mantém a estabilidade com desempenho discreto e área pouco expressiva, fato que aliás já vem ocorrendo há algum tempo. O produtor médio de cana-de-açúcar na etapa I é incapaz de cobrir seus custos fixos e na etapa II pode pagar apenas $31 \%$ do custo de energia elétrica. Sua DAP* pela água é de $\mathrm{R} \$ 6,70 / \mathrm{mil} \mathrm{m}^{3}$. Isto significa que a cultura da cana-de-açúcar tende a desaparecer do projeto mantendo-se os níveis de preços e tecnologia do ano agrícola de 1995/96. Pelo observado, isto talvez possa explicar a razoável taxa de inadimplência dos irrigantes nos pagamentos das contas de energia elétrica.

${ }^{37}$ As perdas devem ser bem superiores, considerando que este estudo se reporta a $55,5 \%$ da água total . 
Tabela 22 - VBP proposto e obtido, despesas fixas, DAP* proposta e efetiva e gastos efetivos com energia elétrica por cultura, projeto Curu-Paraipaba, Estado do Ceará, ano agrícola 1995/96. (em mil reais).

\begin{tabular}{|c|c|c|c|c|c|c|}
\hline \multirow[t]{2}{*}{ Culturas } & \multicolumn{2}{|c|}{ VBP } & \multirow{2}{*}{$\begin{array}{c}\text { Despesas } \\
\text { Fixas }\end{array}$} & \multicolumn{2}{|c|}{ DAP* } & \multirow{2}{*}{$\begin{array}{c}\begin{array}{c}\text { Energia } \\
\text { Elétrica(1) }\end{array} \\
\text { Efetiva }\end{array}$} \\
\hline & Proposto & Obtido & & Proposto & Efetiva & \\
\hline Coco & $2.558,3$ & 647,3 & 169,2 & $2.389,1$ & 478,1 & 37,4 \\
\hline Mamão & 233,4 & 128,3 & 100,6 & 132,8 & 27,7 & 16,0 \\
\hline $\begin{array}{l}\text { Cana-de-açúcar } \\
\text { (et.1) }\end{array}$ & 964,5 & 315,2 & 321,2 & 643,3 & $-6,0$ & 66,9 \\
\hline $\begin{array}{l}\text { Cana-de-açúcar } \\
\text { (et.2) }\end{array}$ & 784,1 & 229,7 & 206,2 & 577,9 & 23,5 & 81,8 \\
\hline Total & $4.540,3$ & $1.320,5$ & 797,2 & $3.743,1$ & 523,3 & 202,1 \\
\hline
\end{tabular}

Fonte: (1) DNOCS.

Nota: Os demais valores foram calculados pelo autor, utilizando os dados da pesquisa.

A Tabela 23 mostra que a DAP* total por água seria de $\mathrm{R} \$ 3.743,1$ mil no ano agrícola de 1996/96. O coco participaria com 63,8 \% desta disposição a pagar por água, seguido da cultura da cana-de-açúcar nas etapas I e II, com respectivamente 17,2\% e 15,5\%. A menor parcela de DAP* seria do mamão, com R\$132,8 mil.

A alta $\mathrm{DAP} *$ pela água reflete a grande importância deste fator em projetos de irrigação. No caso de culturas permanentes em franca produção, a falta de água pode significar perdas irreversíveis de investimentos feitos e da garantia de rendas presentes e no futuro. 
Tabela 23 - DAP*, valor a pagar, excedente e despesas com energia elétrica proposta, por cultura, no projeto Curu-Paraipaba, Estado do Ceará, ano agrícola 1995/96. (em mil reais).

\begin{tabular}{lrrrr}
\hline Culturas & $\begin{array}{c}\text { DAP* pela Água } \\
\text { (A) }\end{array}$ & $\begin{array}{c}\text { Valor a } \\
\text { Pagar (B) }\end{array}$ & $\begin{array}{c}\text { Excedente } \\
(\mathrm{A}-\mathrm{B})\end{array}$ & $\begin{array}{c}\text { Energia Elétrica } \\
\text { Modelo } \\
\text { Proposto }\end{array}$ \\
\hline Coco & $2.389,1$ & 635,7 & $1.753,4$ & 113,6 \\
mamão & 132,8 & 55,7 & 77,1 & 9,3 \\
cana-de-açúcar (et.1) & 643,3 & 226,1 & 417,2 & 40,4 \\
cana-de-açúcar (et.2) & 577,9 & 247,3 & 330,6 & 41,2 \\
\hline Total & $3.743,1$ & $1.164,8$ & $2.578,3$ & 204,5 \\
\hline
\end{tabular}

Fonte: Dados da pesquisa.

Como se sabe, o valor de $\mathrm{R} \$ 140,61 / \mathrm{mil} \mathrm{m}^{3}$ é um preço marginal, ou seja, da última unidade de água ministrada às culturas em conjunto. O preço intramarginal é sempre superior a $\mathrm{R} \$ 140,61 / \mathrm{mil} \mathrm{m}^{3}$. O que o irrigante na verdade pagaria pela água é inferior à DAP*, sendo o retângulo com os lados representados pelo preço e quantidade. Vai existir um excedente representado pela diferença entre a $\mathrm{DAP}^{*}$ e o que seria efetivamente pago pela água destinada à irrigação, que totaliza $\mathrm{R} \$ 2.578,3$ mil. Vale lembrar que da DAP* já estão deduzidos os custos fixos.

Em suma, se no modelo atual de distribuição, os irrigantes pagassem integralmente as despesas com energia elétrica, sobrariam apenas $\mathrm{R} \$ 321,2$ mil. Este excedente atual é o resultado da subtração dos custos fixos e das despesas com energia elétrica, do VBP obtido, explicitados na Tabela 22. Atente-se que este valor decorre quase que exclusivamente aos retornos verificados na cultura do coco. Como nem todos exploram esta cultura e a cana-de-açúcar é predominante, parte das despesas de energia 
deixa de ser ressarcida, cabendo ao Estado suprir o projeto com elevados subsídios. Isto tem ocorrido historicamente.

A forma vigente de distribuição talvez possa explicar por que muitos irrigantes alugaram, ou mesmo venderam, seus lotes, para se dedicar a outras atividades econômicas. Se tomaram medidas tão extremas, significa que negociações menos radicais foram e continuam sendo efetuadas com fatores de produção. Isto explica a existência, em alguns casos, de produtores de coco que adquirem água adicional. Certos irrigantes abdicam da oportunidade de usar água em suas glebas, inclusive vendendo parte da sua força de trabalho para vizinhos. Este é um sinal inequívoco de que eles estariam ganhando mais pela venda dos seus fatores, do que através de suas próprias explorações.

O valor a ser pago pela água destinada a cada cultura ${ }^{38}$, no modelo proposto, permitiria cobrir os seus respectivos custos de energia elétrica, que é de R\$204,5 mil. Este significa apenas $17,5 \%$ do valor que poderia ser arrecadado, caso o modelo de demanda aqui proposto fosse aplicado. Além de cobrir os custos de energia elétrica, poderia ser constituído um fundo só com o valor arrecadado do pagamento da água, num montante um pouco superior a $\mathrm{R} \$ 960,0$ mil. Estes recursos poderiam ser alocados na manutenção ${ }^{39}$ e até na expansão do sistema de suprimento dágua. Ao preço de RS 100,00/medidor instalado, daria para adquirir 9.600, em apenas 1 ano de uso racional de água, destes equipamentos de controle. Investimentos em desenvolvimento tecnológico e assistência técnica privada poderiam ser viabilizados, beneficiando, no longo prazo, todos os irrigantes. Além disso, o projeto seria capitalizado com um montante superior a $\mathrm{R} \$ 2.500,00$ mil, representados pelo excedente registrado na Tabela 23.

\footnotetext{
${ }^{38}$ Os irrigantes que não quisessem ou não pudessem aderir ao sistema proposto poderiam manter-se no sistema de distribuição vigente. Vale lembrar que $45,5 \%$ da água total liberada no Projeto CuruParaipaba, no ano agricola 1995/96. não foram considerados neste estudo.

${ }^{39}$ Vale relembrar que, no capítulo 1, cita-se uma avaliação da COGERH constatando perdas de vazão superiores a $50 \%$ do potencial do canal no projeto Curu-Recuperação. Isto em decorrência da existência de inúmeros buracos ao longo do canal, por falta de manutenção adequada.
} 
Dividindo-se o valor bruto da produção pela quantidade utilizada de água por cultura nos modelos de distribuição vigentes e propostos, obtém-se uma medida ${ }^{40}$ de produtividade da água. Em termos gerais, esta deve mais do que triplicar. A Tabela 24 mostra que apenas as culturas do coco e do mamão poderiam pagar o valor de $\mathrm{R} \$$ $140,61 / 1000 \mathrm{~m}^{3}$ dentro do modelo de distribuição dágua vigente. Este modelo levaria a grandes perdas da produtividade da água em todas as culturas. Em termos relativos, a cana-de-açúcar explorada na etapa II teria o maior incremento na produtividade da água que cresceria mais de seis vezes, se fosse cobrado o preço eficiente. $O$ baixo incremento da produtividade da água na cultura do coco deve-se ao patamar já elevado da produtividade da água desta cultura no modelo vigente, ao contrário das demais, principalmente da cana-de-açúcar da etapa II. Mesmo assim, a cultura que apresenta a menor produtividade da água no modelo proposto (cana-de-açúcar da etapa II) ainda supera a de maior produtividade no modo de distribuição prevalecente (coco).

Tabela 24 - Produtividade da água expressa pelo valor bruto da produção (em mil reais) por mil $\mathrm{m}^{3}$ de água, do modelo de distribuição proposto e vigente, por cultura, no projeto Curu-Paraipaba, Estado do Ceará, ano agrícola 1995/96.

\begin{tabular}{lccc}
\hline Culturas & $\begin{array}{c}\text { VBP/1000m } \\
\text { Modelo Proposto }\end{array}$ & $\begin{array}{c}\text { VBP/1000 } \\
\text { Modelo Vigente }\end{array}$ & $\begin{array}{c}\text { Incremento } \\
(\%)\end{array}$ \\
\hline Coco & 565,9 & 434,6 & 30,2 \\
Mamão & 589,1 & 201,6 & 92,2 \\
Cana-de-açúcar (et.1) & 599,7 & 118,3 & 406,9 \\
Cana-de-açúcar (et.2) & 445,8 & 65,7 & 578,5 \\
\hline Total & 548,0 & 159,4 & 243,7 \\
\hline
\end{tabular}

Fonte: Dados da pesquisa.

${ }^{40}$ Medidas em termos de valor podem ser comparáveis entre culturas. 
A Tabela 24 mostra algo relevante, ou seja, todas as culturas poderiam pagar $\mathrm{R} \$ 140,61 / \mathrm{mil} \mathrm{m}^{3}$ de água no modelo de distribuição proposto. Em termos gerais, este preço representaria $25,6 \%$ do valor da produção por mil $\mathrm{m}^{3}$ de água. Do modo de distribuição vigente, o valor total da produção por mil $\mathrm{m}^{3}$ de água supera em apenas $8,82 \%$ o preço calculado, isto apenas, em razão da razoável produtividade da água exibida pela cultura do coco.

A Tabela 25 permite a comparação entre a DAP* por água e os custos de operação e manutenção do sistema de suprimento. Estes custos envolvem despesas de pessoal, energia elétrica, manutenção da infra-estrutura, inclusive de veículos, e despesas administrativas. Foram obtidos por Gondim Filho $(1992)^{41}$, e os valores estavam em cruzeiros de outubro de $1991^{42}$. Os custos registrados na Tabela 25, representam o produto do custo de $\mathrm{mil}^{3}$ pela quantidade de água efetivamente utilizada e proposta para cada cultura.

Assim, no sistema de distribuição prevalecente, apenas a os que exploram o coco podem arcar com os custos de operação e manutenção. Estes representam um pouco mais da metade da DAP* por água destinada ao coco. Os produtores de mamão e da cana-de-açúcar não estão DAP* pela água que utilizam, o valor que permita cobrir os custos de suprimento. Estes eqüivalem a $\mathrm{R} \$ 174,6$ mil e a $\mathrm{DAP} *$ por água é de apenas $\mathrm{R} \$ 21,7$ mil, ou seja, cobre apenas $12,4 \%$ dos custos. Isto sem considerar a remuneração necessária à sobrevivência do próprio irrigante.

No modelo proposto, o custo total de operação e manutenção do sistema de suprimento, supera o do modelo efetivo em $35,4 \%$. Isto porque na etapa I, a quantidade recomendável de água é maior do que no sistema prevalecente que aloca um volume

${ }^{41}$ Gondim Filho não fez o estudo de custos de suprimento dágua por cultura. Aqui, apenas utilizou-se os resultados de sua pesquisa, para se ter uma idéia aproximada da capacidade de recuperação de custos da água por parte das culturas estudadas.

${ }^{42}$ Utilizou-se o fator de atualização fornecido pela revista SUMA ECONÔMICA, outubro de 1997, ed. $n^{\circ}$ 230 , pg. 15 . 
acima do necessário para cana-de-açúcar na etapa II, quando deveria ser remanejada para os coqueirais.

Tabela 25 - DAP* por água proposta e efetiva e custos totais de operação e manutenção de sistema de suprimento propostos e efetivos, por cultura, etapa I do projeto Curu-Paraipaba, Estado do Ceará, ano agrícola de 1995/96, em mil reais, a preços de dezembro de 1995.

\begin{tabular}{lcccc}
\hline \multirow{2}{*}{ Culturas } & \multicolumn{2}{c}{ DAP* por Água (1) } & \multicolumn{2}{c}{$\begin{array}{c}\text { Custos de Operação e } \\
\text { Manutenção (2) }\end{array}$} \\
\cline { 2 - 5 } & $\begin{array}{c}\text { Modelo } \\
\text { Proposto }\end{array}$ & $\begin{array}{c}\text { Modelo } \\
\text { Efetivo }\end{array}$ & $\begin{array}{c}\text { Modelo } \\
\text { Proposto }\end{array}$ & $\begin{array}{c}\text { Modelo } \\
\text { Efetivo }\end{array}$ \\
\hline Coco & $2.389,1$ & 478,1 & 239,1 & 78,8 \\
Mamão & 132,8 & 27,7 & 18,9 & 33,7 \\
cana-de-açúcar (et.1) & 643,3 & $-6,0$ & 85,1 & 140,9 \\
\hline Total & $3.165,2$ & 499,8 & 343,1 & 253,4 \\
\hline
\end{tabular}

Fonte: (1) Dados da pesquisa; (2) Gondim Filho (1992).

Nota: Para possibilitar as comparações, assumiu-se a não alteração no período da estrutura de custos de operação e manutenção que foram devidamente atualizados pelo autor para reais, a preços de dezembro de 1995

O exame da Tabela 25 mostra que a DAP* por água no modelo proposto supera os custos em cada cultura. Estes representam apenas $10 \%$ da DAP* por água na cultura do coco, 14,2 \% no mamão e 13,2 \% na cana-de-açúcar. De um modo geral, os custos totais de operação e manutenção do sistema de suprimento representam apenas $10,8 \%$ da real DAP* por água, quando destinada à todas as culturas. 


\section{CONCLUSÕES}

Se prevalecessem na safra 1995/96, os preços médios mensais recebidos pelos produtores de coco, mamão e cana-de-açúcar, observados no período de julho de 1994 a maio de 1998, no projeto Curu-Paraipaba, o preço da água para irrigação seria de R\$ $153,93 / \mathrm{mil} \mathrm{m}^{3}$. Se para o mesmo período, fossem praticados as médias anuais dos preços máximos ou os mínimos dos produtos, os preços da água seriam respectivamente $\mathrm{R} \$ 187,00 / \mathrm{mil} \mathrm{m}^{3}$ ou $\mathrm{R} \$ 124,83 / \mathrm{mil} \mathrm{m}^{3}$.

Este resultados confirmam que, quanto maior for o preço do produto, maior será o valor da água. Daí a grande importância da seleção cuidadosa das culturas a serem irrigadas no semi-árido cearense. Mais objetivamente, se a água é escassa, a maneira de valorizá-la é fazer a irrigação em culturas de alto valor.

Considerando os preços observados no ano agrícola de 1995/96, época do estudo, a identificação e análise das curvas de curto prazo da demanda por água, em face com a oferta fixa, permitiu determinar o seu preço de equilíbrio no projeto CuruParaipaba, em $\mathrm{R} \$ 140,61 / \mathrm{mil} \mathrm{m}^{3}$.

Se o acesso à água fosse limitado apenas àqueles que estivessem dispostos a pagar este preço, o primeiro impacto no projeto seria a seleção dos irrigantes mais eficientes. O incremento observado no valor bruto da produção (VBP) seria de 3,43 vezes. O ganho adicional representaria, em termos absolutos, $\mathrm{R} \$ 3,22$ milhões, no ano agrícola de 1995/96, somente nas culturas em estudo.

As quantidades de água demandadas pelas culturas, ao preço de R $140,61 / \mathrm{mil}$ $\mathrm{m}^{3}$ são diferentes das quantidades alocadas no esquema de distribuição vigente. 
Atualmente as tarifas são estabelecidas com vistas a cobrir apenas os custos de energia elétrica.. A análise mostrou que somente os produtores de coco pagariam R $\$ 140,61 / \mathrm{mil}$ $\mathrm{m}^{3}$ pelos 3 milhões de $\mathrm{m}^{3}$ que foram destinados aos produtores da cana-de-açúcar e do mamão. Estes últimos, só poderiam pagar preços inferiores. Assim sendo, 36,6\% de toda a água ofertada às culturas em estudo estariam sendo alocados em atividades que atribuem menor remuneração ao uso desse importante fator. Este é um possível indicador de tamanho da ineficiência. Se o mercado de um fator fundamental à produção, caso da água, apresenta falhas que levam a sua ineficiência e desorganização, isto se transmite e repercute negativamente em todo o processo produtivo.

O importante é que, se do VBP obtido do esquema de distribuição proposto, fossem deduzidas todas as despesas fixas que totalizam $\mathrm{R} \$ 797,2$ mil e mais os gastos com energia elétrica necessários ao bombeamento e adução, no montante de $R$ \$202,1 mil, ainda sobrariam $\mathrm{R} \$ 3,54$ milhões. Isto representa 2,7 vezes o VBP gerado no atual esquema de distribuição vigente. Nesse, o VBP obtido pelos produtores de cana-deaçúcar na etapa é insuficiente para cobrir os gastos com energia elétrica.

Os resultados desta pesquisa confirmam os verificados em vários estudos econômicos em projetos de irrigação no Nordeste. Ou seja, a baixa produtividade e a insuficiência de renda do irrigante, são prevalecentes na maioria dos casos.

Com baixa rentabilidade, torna-se impossível remunerar os fatores de produção em seu melhor uso alternativo. A terra não recebe reposição de nutrientes, acarretando perdas contínuas de fertilidade. A falta de reposição do capital contribui para a baixa eficiência da irrigação, ocasionando elevadas perdas de água. A evasão de jovens, em busca de outras opções de trabalho, pode ser conseqüência da baixa remuneração no projeto.

Em sua maioria, os irrigantes, antes produtores sem terra, foram selecionados e receberam glebas totalmente sistematizadas com distribuição dágua em pleno semiárido cearense. No inicio do projeto, contavam com generosos volumes de crédito, subsídios para energia elétrica e disponibilidade de mão-de-obra familiar. Esses fatores, 
aparentemente favoráveis, em contradição com o contínuo empobrecimento dos produtores, permitem concluir que o esquema de distribuição dágua vigente teve influência não desprezível no aumento desta pobreza.

Os aspectos políticos e culturais no Nordeste tem sido um entrave ao controle de uso da água em projetos de irrigação. Do ponto de vista político, por envolverem um amplo espectro ideológico. De um lado, justificam interesses corporativos, via fortalecimento da estrutura tecno-burocrática do Estado, carreando recursos para infraestrutura e serviços de assistência técnica e outros, tudo em nome do aumento de produtividade, que como mostrado, vem decrescendo. De outro, pela idéia de a água ser um direito de todos, devendo cumprir um papel social nos projetos de irrigação pública. Isto reflete a cultura predominante, ou seja, a água é uma dádiva da natureza, feita para todos os homens e, portanto, não é legítimo, do ponto de vista ético, submetê-la às leis do mercado.

Neste cenário, a política de emancipação dos projetos públicos de irrigação no Nordeste torna-se limitada. Se a maioria dos irrigantes, conforme os resultados revelados, não podem em muitos casos pagar uma tarifa reconhecidamente baixa pela água, como poderão fazer a irrigação sem um alto grau de subsídio?

$\mathrm{Na}$ forma de distribuição dágua proposta nesta tese, os modelos mostram claramente a necessidade de incentivos para as culturas mais competitivas. Embora em termos quantitativos os resultados obtidos só possam ser conclusivos no tocante à água, pode-se afirmar que a expansão da cultura do coco deveria ser fortemente estimulada.

As estimativas das funções de produção de onde se derivaram as curvas de demanda de curto prazo da água, permitiram identificar elasticidades parciais de produção, rendimentos à escala, valores dos produtos médios e marginais e influência de fatores sócioeconômicos e tecnológicos sobre as elasticidades parciais.

Tais resultados permitem concluir que a educação tem impacto positivo sobre a produtividade do capital na cultura do coco. Assim sendo, fica claro que investimentos em educação aumentaria a economia de escala da função de produção do coco e 
consequentemente, a produtividade de todos os fatores. Sugerem também a existência de alguns problemas decorrentes do atual sistema de distribuição dágua. Isto, porque ele obriga os irrigantes a utilizar água através de "acordo de cavalheiros", em que cada um não tente levar vantagem através de práticas ilícitas, como a do aumento da vazão dos aspersores. Este acordo aparentemente só vem sendo cumprido no caso do coco.

Mas, em economia, raramente os participantes são "cavalheiros" e, se o forem, será por pouco tempo. Isto foi o que se observou com a cultura do mamão e da cana-deaçúcar, principalmente na etapa I. O coeficiente negativo do capital de irrigação nessas culturas, pode não estar apontando para o uso excessivo deste fator. É mais provável que tenha ocorrido quebra de "acordo", ou seja, alguns tiram vantagem ampliando suas vazões. Isto contribui para reduzir o rendimento à escala da função de produção $(0,65)$, causando impactos negativos sobre a produtividade dos fatores.

O modelo proposto diminui $240 \mathrm{mil} \mathrm{m}^{3}$ de água dos produtores de mamão. Recomenda também para os que exploram esta cultura, incentivos específicos para a adoção de tecnologias poupadoras de mão-de-obra e, obviamente, de água. De forma isolada, deve-se aumentar a intensidade de uso dos insumos.

O mesmo poderia ser feito com os produtores de cana-de-açúcar na etapa I, quando o modelo retira um volume de $1.056,3 \mathrm{mil} \mathrm{m}^{3}$ de água. A elasticidade total de produção é igual a 0,8 , ou seja, rendimentos decrescente à escala. Políticas que favorecem o incremento simultâneo de todos os fatores não seriam convenientes e o uso indevido do capital provavelmente contribuiu para esta situação.

Na etapa II, o problema de escassez dágua não é tão agudo como na etapa I e prática ilícitas não foram detectadas pelo modelo. A atividade monopsônica se reflete na relação inversa entre mão-de-obra e produção como demonstrado no capítulo anterior. Por não ser propriamente um problema de natureza tecnológica, verificou-se que os rendimentos à escala da função de produção não foram afetados, daí continuar sendo homogênea de grau 1, ao contrário do que aconteceu com as funções de produção do mamão na etapa I e cana-de-açúcar na etapa I. Mesmo assim, o modelo proposto reduz 
as disponibilidades para esses últimos, retirando-lhes $1.735,2,3 \mathrm{mil}^{3}$ de água $\mathrm{e}$ sugerindo remanejar este volume para a cultura do coco na etapa I.

Quanto à assistência técnica, que a maioria dos estudos recomendam sua expansão para o aumento da produtividade, poderia melhorar o padrão de vida dos irrigantes, se houvesse controle de uso da água. Pouco pode fazer para elevar os níveis de renda dos produtores, no cenário descrito anteriormente. Nos modelos utilizados nesse estudo, os parâmetros testados de assistência técnica sempre se mostraram não significativos.

A partir dessas conclusões, projetos de irrigação no Nordeste, (pelo menos no caso do Curu-Paraipaba e com base nos resultados obtidos) seriam altamente rentáveis, se fosse assegurado o direito de uso da água apenas para aqueles que tivessem com DAP o preço eficiente da água. Não poderia ser de outra maneira, ou seja, esperar uma razoável rentabilidade econômico-financeira num projeto de irrigação em que o principal fator de produção não é submetido ao controle de uso.

O modelo teórico e o procedimento metodológico adotados nesta pesquisa consistem de uma avaliação ex-post, válida apenas nas condições do ano agrícola de 1995/96, do projeto Curu-Paraipaba. Entretanto, poderão ser úteis e adaptados aos esforços de programação visando a distribuição dágua entre culturas exploradas em outros projetos de irrigação. Vale ressaltar ainda que não se propõe nenhuma ampliação do volume de recursos disponíveis; sugere-se tão somente redistribuir a água, através do seu valor econômico. O modelo será válido, se e somente se, forem especificados e assegurados os direitos de uso, apenas àqueles que estejam dispostos a submeter-se ao controle da água por medidores.

Alguns problemas de natureza econométrica e econômica merecem aqui referência especial. No primeiro caso, funções de produção que usam modelos de produção total, podem registrar a presença de multicolinearidade, com todas as suas implicações pouco desejáveis. Felizmente, porém, as análises estatísticas mostram que este problema é irrelevante nesta pesquisa, assim como o de heterocedasticidade. 
Do ponto de vista econômico, há três restrições importantes: i) o modelo utilizado, é de equilíbrio parcial, ou seja, considera como dados os outros usos de água (consuntivos e não-consuntivos), o que é uma simplificação da realidade; ii) nas estimativas do VPMg da água, são mantidos fixos os demais fatores de produção em torno de sua média; e, iii) as elasticidades preços da demanda por água são constantes, em virtude da curva da demanda ser uma hipérbole, o que pode ser uma descrição mais simplificada do mundo real.

Considerando os resultados, conclusões e limitações até aqui descritas, são apresentadas a seguir algumas idéias sobre procedimentos e estudos que poderiam compor uma linha de pesquisa econômica sobre recursos hídricos no Nordeste. São eles:

i) Os estudos seriam feitos prioritariamente, com base em dados primários, por equipes interdisciplinares, pois além dos aspectos agroeconômicos, existem variáveis sócio-culturais de importância decisiva no uso da água. A visão meramente quantitativa, a partir de dados secundários, quase sempre não contempla os aspectos humanos da mais alta importância; e,

ii) Os resultados e conclusões deste estudo poderiam ser testados em outros projetos de irrigação pública, através de novas pesquisas sobre o assunto. Para melhor avaliação, poderiam ser feitos estudos comparativos em projetos com e sem direitos assegurados de exclusividade no uso da água.

Os estudos que poderiam ser desenvolvidos são os seguintes:

a) Testar outros métodos disponíveis para determinar a demanda dágua, tais como, residual, demanda derivada, programação linear, inclusive da função de produção, procurando identificar os mais adequados para situações específicas;

b) Efetuar estudos utilizando modelos de equilíbrio geral, para obter uma visão do conjunto de usos opcionais para água, desde o uso consuntivo (urbano, irrigação, uso de animais), até não-consuntivo (pesca, navegação, lazer e geração de energia elétrica). Esses usos não são independentes, de sorte que uma dada utilização 
pode afetar as demais. A aplicação da matriz insumo-produto, poderia ser um instrumental interessante. Serviria de subsídios para um possível conjunto de ações visando a interligação entre bacias hidrográficas no Nordeste;

c) Contemplar as implicações econômicas, sociais e políticas do processo em vigor de privatização de companhias urbanas de fornecimento dágua;

d) Efetuar estudos de demanda e oferta dágua de longo prazo;

e) Dever-se-ia priorizar estudos que indiquem as estratégias a serem seguidas para um efetivo controle de uso da água em projetos de irrigação pública. Seria especificar e assegurar que o irrigante disponha de água na quantidade, qualidade e tempo requeridos, desde que os usos sejam destinados para as opções de maior retorno econômico deste valioso insumo. 


\section{REFERÊNCIAS BIBLIOGRÁFICAS}

AGÜERO, P.H. Avaliação econômica dos recursos naturais. São Paulo, 1996. 224p. Tese (doutorado) - Faculdade de Economia e Administração, Universidade de São Paulo.

ALMEIDA, J.R.de, Análise econômica da produção de leite da bacia leiteira de Salvador-Bahia. Viçosa-MG, 1972. Dissertação (Mestrado) - Universidade Federal de Viçosa.

ARAÚJO, H.R.G.de. Replanejamento e Rentabilidade Econômica das Explorações Agropecuárias no Perímetro Irrigado Curu-Paraipaba (CE). Fortaleza, 1995. 88p. Dissertação (Mestrado) - Universidade Federal do Ceará.

ARROW, K; MINHAS, B.; SOLOW, R.M. Capital-labor substituition and economic eficiency. Review of economics and statistics 43(1961).,pp 228-232.

ASSIRATI, E.B. Uma avaliação das políticas de irrigação no Nordeste. Revista Econômica do Nordeste, v.25, n.4, p.545-574, out/dez. 1994.

AZEVEDO, R.; LEMOS, J.J.S. Comportamento da renda e da produtividade agrícola em perímetros irrigados do Nordeste. Revista de Economia e Sociologia Rural, v.27, n.3, p.253-269, jul./set.; 1989.

BARBOSA, F. H. de. Microeconomia: Teoria, Modelos Econométricos e Aplicações à Economia Brasileira. Rio de Janeiro, IPEA/INPES, 1985. 556 p.

BARROS, G. S. C. de. Economia da comercialização agrícola. Piracicaba (SP), FEALQ, 1987. $306 \mathrm{p}$. 
BEATTIE, B.R.; TAYLOR, C.R. The Economics of Production - New York: Montana University, 1989.235p.

BERNARDO, S. Manual de Irrigação. Viçosa-MG. $2^{a}$ ed. Imprensa Universitária da UFV, 1982. 463p.

BISERRA, J.V.; Rentabilidade da irrigação pública no Nordeste sob condições de risco.

O caso do perímetro Morada Nova. Revista de Economia e Sociologia Rural, v.32, n.3, p.289-303, jul./set., 1994.

BRASIL. Ministério do Meio Ambiente. Superintendência de Desenvolvimento do

Nordeste. Aspectos Gerais da Agropecuária do Nordeste. Recife, 1984. 406p. (Série Projeto Nordeste, 3).

BRASIL. Ministério da Integração Regional. Departamento Nacional de Obras Contra as

Secas. Estudos de Operações Conjuntas de Reservatórios da Bacia do Curu. Fortaleza, 1993.

BRASIL. Ministério do Meio Ambiente. Departamento Nacional de Obras Contra Secas. Perímetros Irrigados Curu-Paraipaba/Plano de Ação Global-Serviços Integrados de Assessoria e Consultoria Ltda. Fortaleza, 1993.

BRASIL. Ministério do Meio Ambiente. Departamento Nacional de Obras Contra Secas.

Custos e receitas das principais culturas dos perímetros irrigados. Diretoria de Irrigação (DIRGA) - Grupo de Apoio à Produção (GAP). Fortaleza, 1995.

BRASIL. Ministério do Meio Ambiente. Departamento Nacional de Obras Contra as

Secas. Perímetro Irrigado Curú-Recuperação (Plano de Ação Global). Fortaleza: SIRAC-Serviços Integrados de Assessoria e Consultoria Ltda, 1993.

BRISCOE, J. Toward Equitable and Sustainable Rural Water Supplies: A Contingent Valuation Study in Brazil. Washington: BIRD, 1990. 19p. 
CAMARGO. J.R.V.de. Análise da Produtividade nas Culturas de Algodão e Soja com a Aplicação do Modelo Ulveling-Fletcher. Piracicaba-SP, 1974. Dissertação (MS). Escola Superior de Agricultura Luiz de Queiroz.

CAMPOS, R.T.; KHAN, A.S. Efeitos das secas sobre o pequeno produtor rural do Nordeste. Revista Econômica do Nordeste, v.20, n.1, p.9-30, jan./mar., 1989.

CASIMIRO FILHO, F. \& SHIROTA, R. Valoração econômica de áreas de recreação: uma proposta metodológica. Anais do XXXV Congresso Brasileiro de Economia e Sociologia Rural.(CD)-. Sessão I. Agricultura, meio ambiente e condições de vida. SOBER. Natal-RN., pg. 77 a 92., agosto de 1997.

CEARÁ. SECRETARIA DOS RECURSOS HÍDRICOS. A Nova Política de Águas do Ceará. Fortaleza, 1991.30p.

CEARÁ. SECRETARIA DOS RECURSOS HÍDRICOS. Plano Estadual de Recursos Hídricos. (Estudos de base). Fortaleza, 1994.419p.

CEARÁ. SECRETARIA DOS RECURSOS HÍDRICOS. Cadastramento dos Usuários de Água Bruta da Bacia do Curú-Relatório Final - VBA CONSULTORES E ENGENHARIA DE SISTEMAS HÍDRICOS LTDA. COGERH. Fortaleza 1995.

CHIANG, A. Matemática para Economistas. São Paulo: Mc Grau do Brasil; EDUSP, 1982. 683p.

CHRISTENSEN, L.R., JORGENSON, D. W., e LAU, L. J. Transcendental logarithimic production frontiers. Review of Economics and Statistics. 55:1 (1973) pp.28-45.

CLINE, W. R.. Economic Consequences of a Land Reform in Brazil. North-Holland Publishing Company. Amsterdam-London. 1970 - Printed in the Netherlands ISBN: $0720431670-213 \mathrm{p}$.

De JANVRY, A. The Generalized Power Production Function. American Journal of Agricultural Economics, vol 54, maio, 1972, pg.234-237. 
DEBERTIN, D.L. Agricultural Production Economics. Macmillan publishing company, USA. 1986 - 365p.

DORFMAN, R. Preços e Mercados. Rio de Janeiro: Zahar, 1977.

FIGUEROA, M. O Problema Agrário no Nordeste do Brasil: Análise e Proposições.São Paulo: HUCITEC, 1977.272p.

FRANÇA, M. ; PEREIRA, J.A. Análise Agroeconômica e Capacidade de Pagamento do Pequeno Irrigante do Nordeste. Fortaleza: BNB-Etene, 1990. 277 p.

FRIEDMAN, M. Teoria dos Preços. Rio de Janeiro: APEC 1971.320p.

GREENE, W.H. Economic analysis - Macmillan publishing company; USA. $2^{\mathrm{a}}$ ed. $1990.269 \mathrm{p}$.

GIANSANTI, A.E. A Água como um Bem Econômico. São Paulo, 1993. 431p. Tese (Doutorado) - Departamento de Engenharia da Escola Politécnica, Universidade de São Paulo.

GONDIM FILHO, J.G.C. Gestão Integrada dos Reservatórios da Bacia do Rio Curú. Fortaleza, 1988. 114p. Dissertação (M.S) Escola de engenharia civil, Universidade Federal do Ceará.

GONDIM FILHO, J.G.C. Determinação da Tarifa Dágua do Projeto de Irrigação CuruParaipaba. Fortaleza,1992.86p. Dissertação (M.S) - Centro de Ciências Agrárias, Universidade Federal do Ceará.

HAlTER, A.N., CARTER, H. O., HOCKING, J. B., A Note on the transcendental production function. Journal of Farm Economics, 39(1957), pp 966-974.

HEADY, E. e DILLON, J. Agricultural Production Functions. Iowa State University

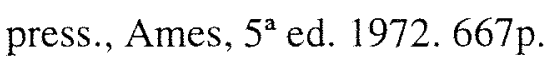

HERBST, P. H. A techique for the evaluation of drought fom raifall data. Journal of Hidrology, v.4, 1986. 
KMENTA, J. Elementos de Econometria, ed Atlas S.A, $1^{a}$ ed.1978.

LANNA, A.E. Estudos para cobrança pelo uso de água bruta no Estado do CearáSimulação tarifária para a bacia do rio Curu. Relatório n². COGERH., Fortaleza, dezembro de 1994.

LANNA, A.E. Estudos para cobrança pelo uso de água bruta no Estado do CearáSimulação tarifária para a bacia do rio Curu. Relatório n²-A. COGERH., Fortaleza, janeiro de 1995.

LEITHOLD, L. Matemática Aplicada à Economia e Administração. São Paulo: Ed. Harbra. 1988., 500p.

LOOMIS, J.B. Water transfer and major environmental provisionais of the Central Valery Project Improvement Act: A preliminary economic evaluation. Water Resources Research, v.30, n.6., p.1865-1871, June 1994.

MELO FILHO, A.N.de, Rentabilidade das Explorações Agropecuárias do Perímetro Irrigado Curu-Paraipaba, Sob Condições de Risco. Fortaleza, 1992. 97p. Dissertação (M.S) - Centro de Ciências Agrárias, Universidade Federal do Ceará.

MISHAN, E.J. Cost-Benefit analysis - An Informal Introduction. London: George Allen \& UNWIN LTD. 1975. 487 p.

MOTA, F.A. Análise dos Custos do Volume Regularizado e da Eficiência Hídrica de Reservatórios do Ceará. Fortaleza, 1995. 86p. Dissertação (M.S) - Escola de Engenharia Civil, Universidade Federal do Ceará.

NIMER, E. Pluviometria e recursos hídricos de Pernambuco e Paraíba. Rio de Janeiro: FIBGE, 1979. (Série Recursos Naturais e Meio Ambiente, 3)

OLIVEIRA, E.M. Avaliação "ex-post" dos Aspectos Socioambientais do Perímetro Irrigado Curu-Paraipaba - Ceará. Dissertação (M.S). Fortaleza. 1994- Centro de Ciências Agrárias, Universidade Federal do Ceará. 
PALÁCIOS, E. V. Introducción a la Teoria de la Operación de Distritos y Sistemas de Riego. Chapingo, México,. 1977.130p.

PINTO FILHO, J. Diagnóstico e Perspectiva da Micro e Pequena Agroindústria de Fruto Tropical no Estado do Ceará. Fortaleza. 1994. Dissertação (M.S). - Centro de Ciências Agrárias, Universidade Federal do Ceará.

QUEIROZ, M. F. de. Impacto socioeconômico do cooperativismo nos perímetros irrigados do DNOCS: O Caso das Cooperativas do Perímetro Irrigado CuruParaipaba. Fortaleza. 1992. Dissertação de mestrado. - Centro de Ciências Agrárias, Universidade Federal do Ceará.

RANDALL, A. Resouce economics: An Economic Approach to Natural Resource and Environmental Policy. 2.ed. Columbus: The Ohio State University, $1987.434 \mathrm{p}$.

SAMPAIO, Y. O setor público e as secas: Uma reflexão sobre a ação governamental em relação as secas nos últimos 25 anos. Revista Econômica do Nordeste, v.18,n.1, p.27-48, jan./mar. 1987.

SCHNEIDER, E. Teoria econômica: capítulos selecionados da história da teoria econômica. $1^{\text {a }}$ ed. Rio de Janeiro: Fundo de cultura S.A., V.4, 1968.395p.

SEMINÁRIO DOS USUÁRIOS DE ÁGUA DO VALE DO CURÚ, 1. Pentecoste, 1995. Relatório Geral.- Fortaleza, COGERH, 1995, 26p.

STIEGLER, G.J.- A Teoria dos Preços-2. ed. São Paulo: Atlas, 1970.358 p.

TEIXEIRA, R.M. Demanda de Água: A Tarifa Vista Sob a Ótica do Preço-Sombra. Rio de Janeiro, 1990. 120p. Dissertação (M.S) - Escola de pós-graduação em economia, Fundação Getúlio Vargas.

THOMPSON, R.L. Economia da produção, Viçosa-MG., Departamento de economia rural-UFV-1973., 222p.(mimeo.). 
TISDEL, C.A. Microeconomia - A Teoria da Alocação Econômica. São Paulo:Atlas, $1978.637 \mathrm{p}$.

ULVELING, E.F.\& FLETCHER, L.B. A Cobb-Douglas production function with variable returns to scale. American Journal of Agricultural Economics. Vol. 52., n. 2 - May 70.

VARIAN, H. R. Microeconomia - Princípios Básicos. Rio de Janeiro; Campos, 1994. 709p.

WEBER, J.E. Matemática para Economia e Administração. São Paulo: Harper \& Row do Brasil Ltda. 1977, 500p.

YOUNG, R. A; GRAY, L. Input-output, economic surplus, and the evaluation of state or regional water plans. Water Resources Research, v.21, n.12, p. 1819-1823, December. 1985.

YOUNG, R.A. On the Allocation, Pricing, and Valuation of Irrigation Water. In: JOHSON, S.H.; YARON, D.; CARRUTHERS, I. Economics aspects: Irrigation management in developing countries - current issues and approaches. Colorado: K.C.Nobe \& K.Sampath,1986. p. 151. 


\section{APÊNDICE 1}

Dados básicos utilizados para a estimativa das funções de produção 


\begin{tabular}{|c|c|c|c|}
\hline 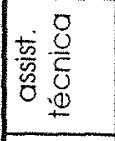 & 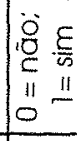 & 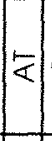 & 100000000--00-00--0000000-0-... \\
\hline 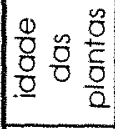 & $\stackrel{2}{0}$ & $\cong$ & $m \sim \infty \omega \infty$ on \\
\hline 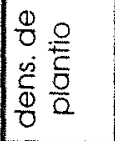 & $\frac{u}{\frac{5}{2}}$ & 号 & 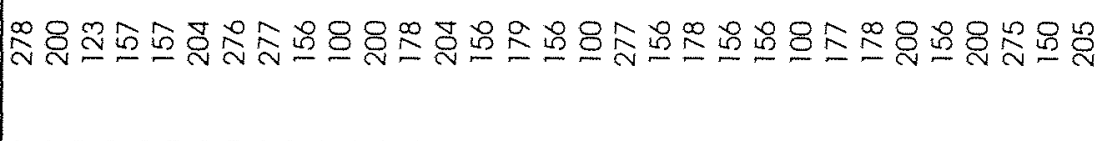 \\
\hline \begin{tabular}{|rr}
0 & $\frac{1}{\frac{1}{3}}$ \\
0 & 0 \\
0 & 0 \\
\end{tabular} & D & $\geq$ & 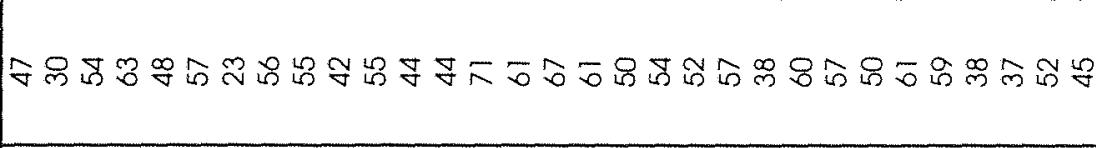 \\
\hline $\begin{array}{l}0 \\
0 \\
0 \\
0 \\
0 \\
0 \\
0\end{array}$ & $\mathscr{l}_{0}^{2}$ & $\frac{\omega}{<}$ & 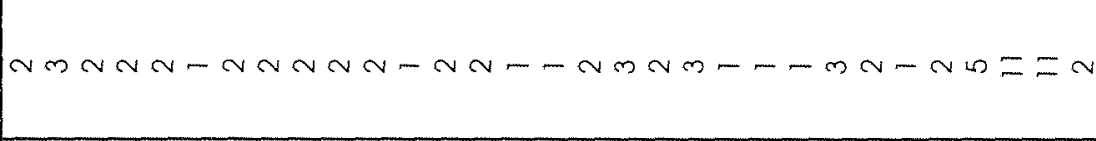 \\
\hline 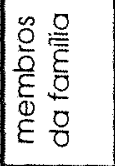 & 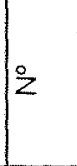 & $\stackrel{4}{\Sigma}$ & 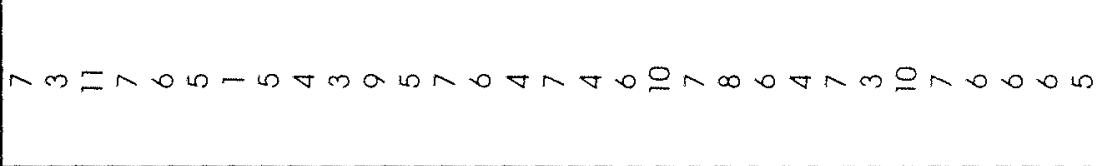 \\
\hline$\frac{\substack{0 \\
\frac{0}{0}}}{\frac{0}{5}}$ & 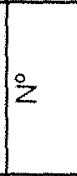 & $\mid \begin{array}{l}\infty \\
0 \\
0 \\
2 \\
z\end{array}$ & 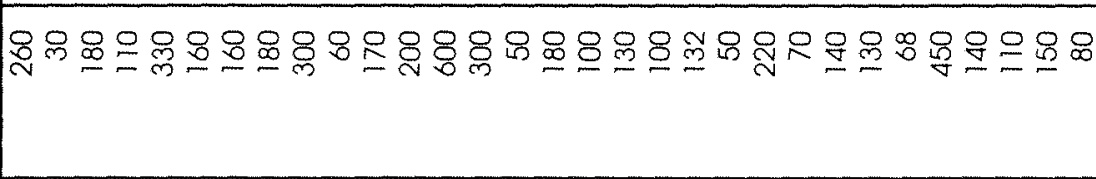 \\
\hline$\stackrel{8}{\mathscr{D}}$ & $\Sigma$ & $\left(\frac{1}{4}\right.$ & 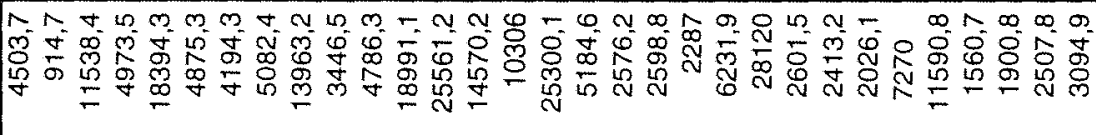 \\
\hline 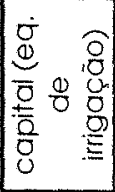 & 2 & & 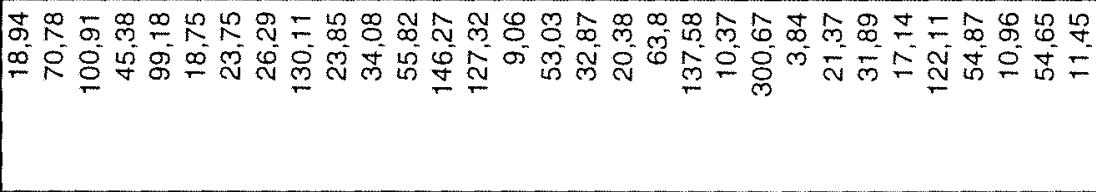 \\
\hline 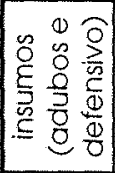 & 分 & & 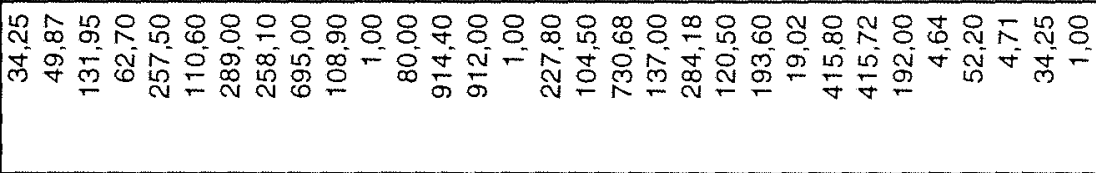 \\
\hline $\begin{array}{l}\frac{0}{0} \\
\frac{\mathscr{E}}{0} \\
\stackrel{0}{E}\end{array}$ & $\frac{0}{2}$ & 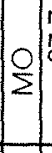 & 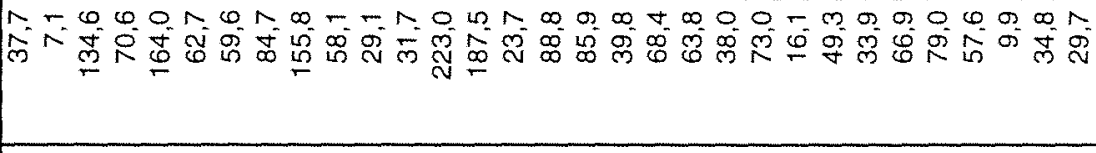 \\
\hline$\stackrel{0}{D} 0$ & I & 4 & 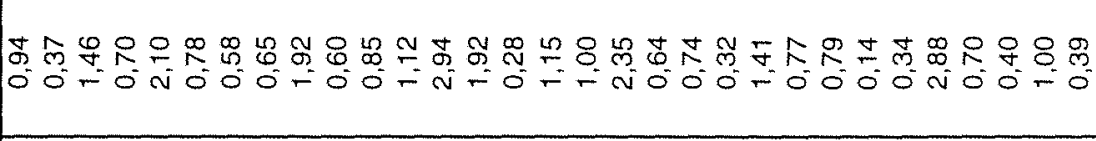 \\
\hline $\mid \begin{array}{ll}0 \\
0 \\
0 \\
0 & 8 \\
3 & 0 \\
0 & 0 \\
0 & 0 \\
0 & 0 \\
0\end{array}$ & $\stackrel{\stackrel{\rho}{\Phi}}{\stackrel{\rho}{=}}$ & $>$ & 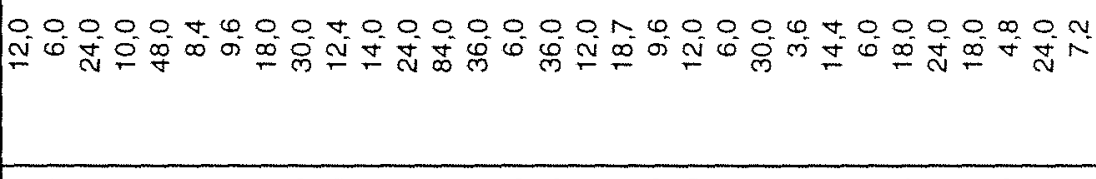 \\
\hline$\stackrel{\leftrightarrow}{0}$ & & & 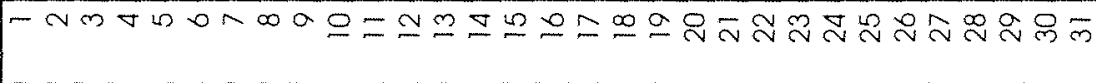 \\
\hline
\end{tabular}




\begin{tabular}{|c|c|c|}
\hline 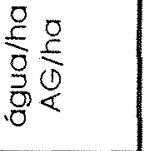 & $\frac{\substack{8 \\
\frac{8}{8}}}{8}$ & 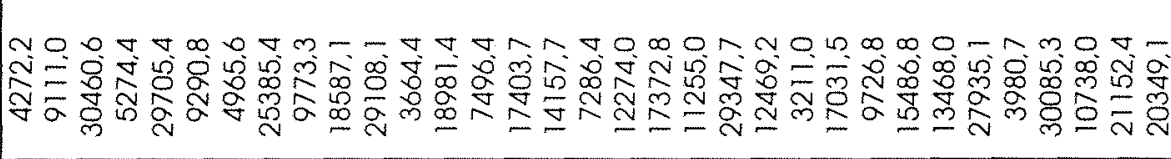 \\
\hline 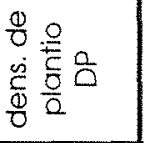 & $\begin{array}{l}\frac{0}{2} \\
\frac{2}{2}\end{array}$ & 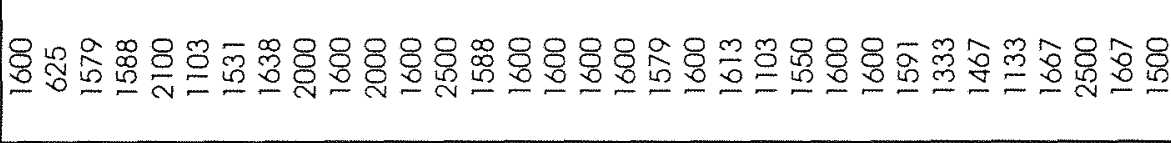 \\
\hline 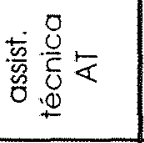 & 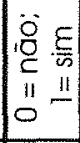 & $0--10-0000--1000--00-0----0--0-0$ \\
\hline 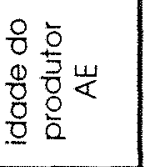 & : & 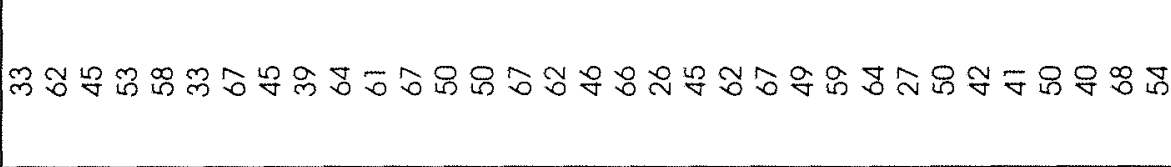 \\
\hline 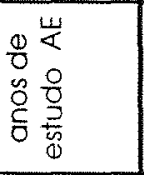 & $\overbrace{0}^{2}$ & 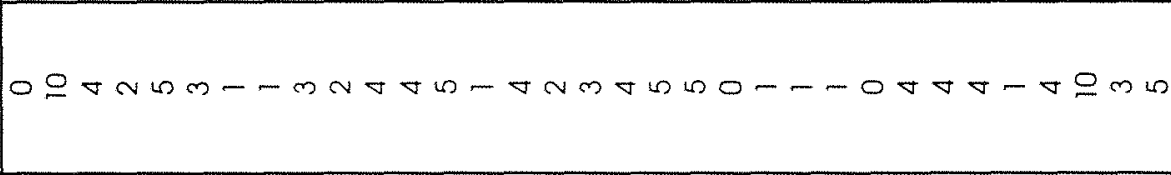 \\
\hline 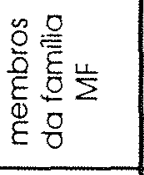 & ic & 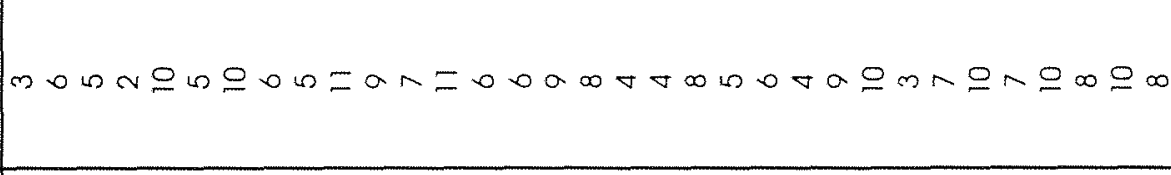 \\
\hline 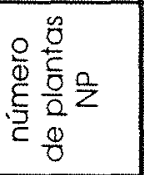 & $\stackrel{\check{E}}{\xi}$ & 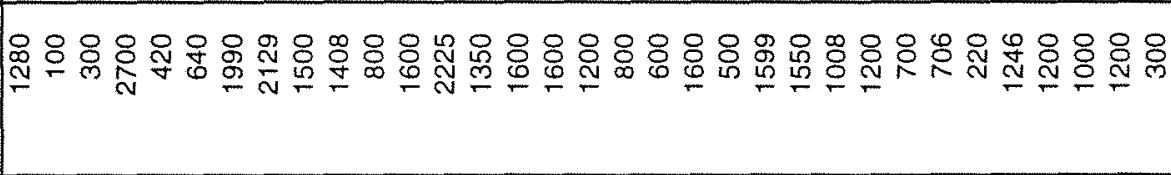 \\
\hline$\frac{0}{8} \frac{0}{8}$ & $\sum$ & 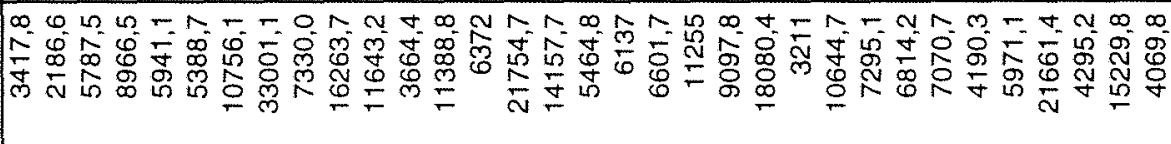 \\
\hline 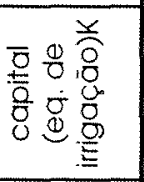 & $\approx$ & 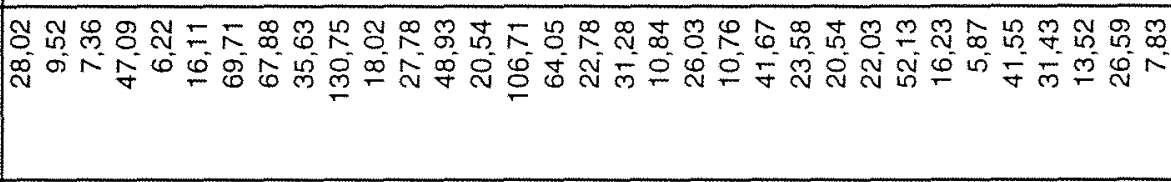 \\
\hline 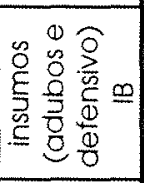 & & 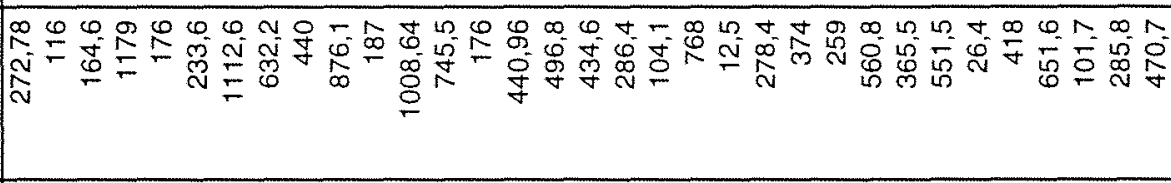 \\
\hline 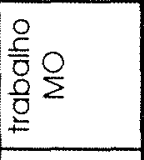 & $\sum_{0}^{2}$ & 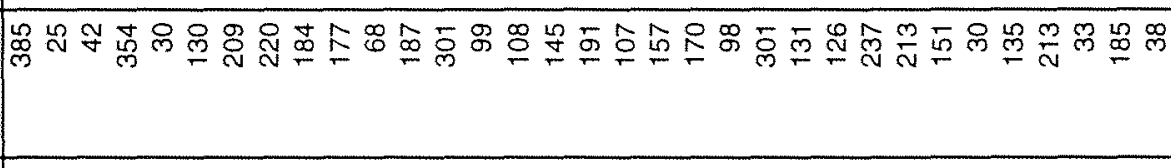 \\
\hline 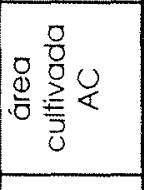 & $\underline{9}$ & 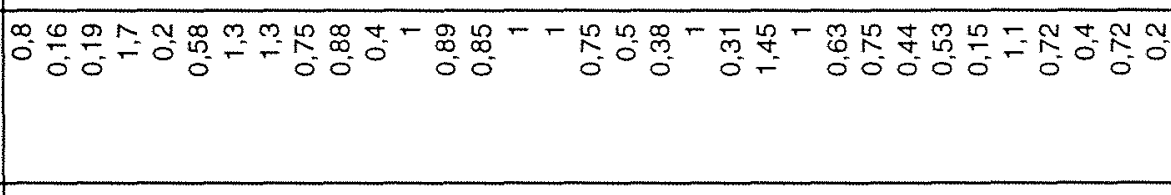 \\
\hline 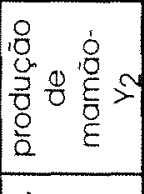 & $\begin{array}{l}8 \\
0 \\
0 \\
0 \\
0 \\
0 \\
0 \\
0\end{array}$ & 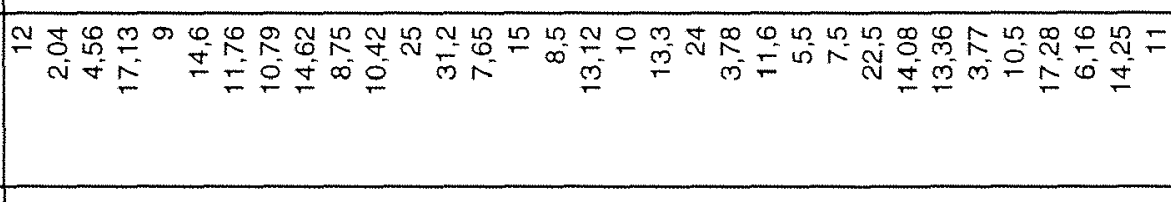 \\
\hline$\frac{10}{0}$ & & 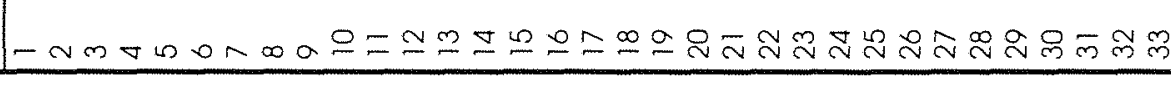 \\
\hline
\end{tabular}




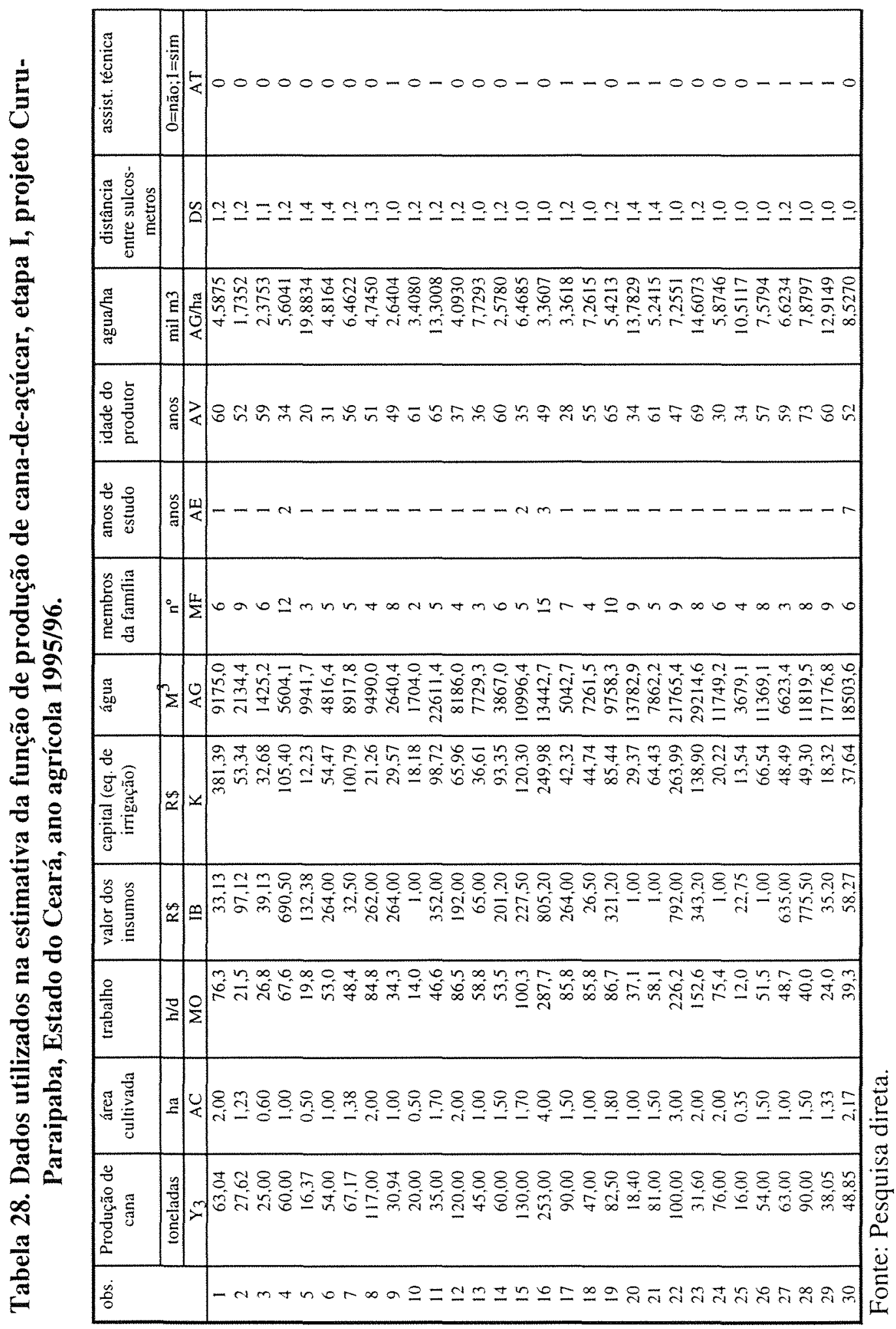




\begin{tabular}{|c|c|c|}
\hline 尊总 & 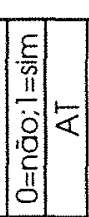 & $0000-000-10-0---0-00-1--00-$ \\
\hline 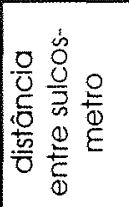 & $\overrightarrow{0}$ & 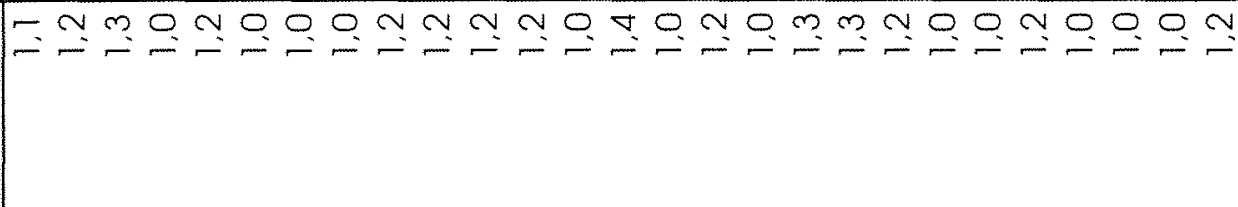 \\
\hline$\frac{0}{8} \frac{0}{2}$ & $\begin{array}{lll}0 \\
0\end{array}$ & 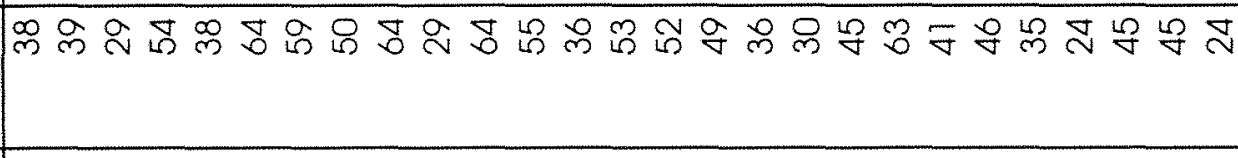 \\
\hline 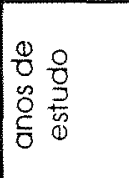 & 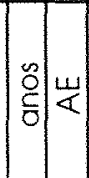 & $n-=N n m 000 n-0-m m n m=\underline{L}-m-m n \underline{-}$ \\
\hline 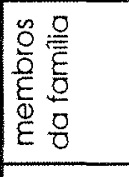 & $\therefore \frac{1}{\Sigma}$ & 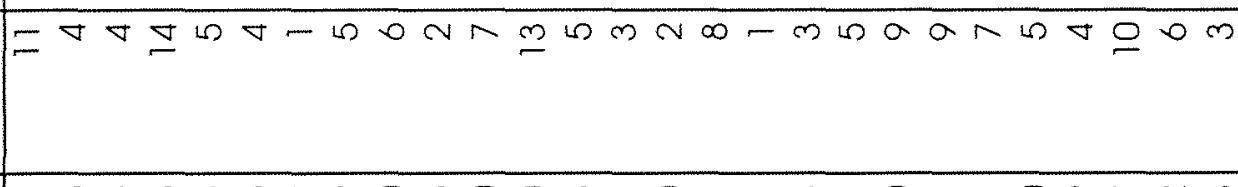 \\
\hline 总 & $2=18$ & 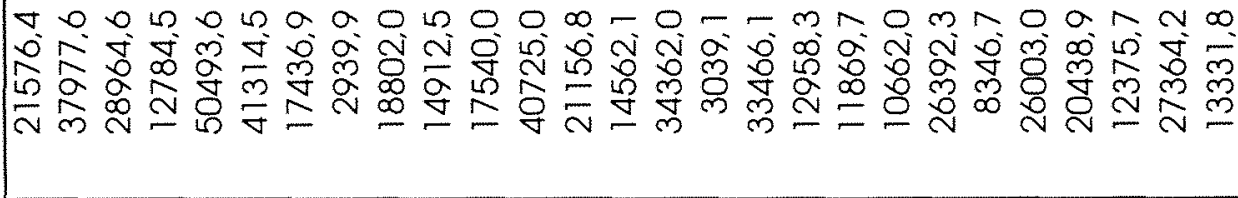 \\
\hline 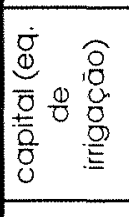 & $(x$ & 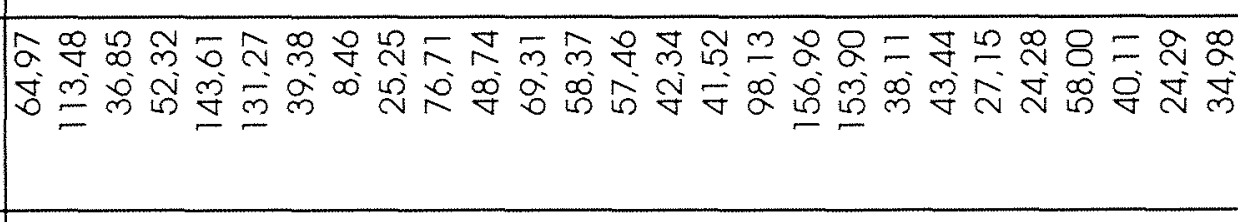 \\
\hline 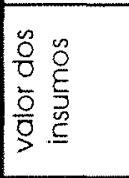 & $\approx \cong$ & 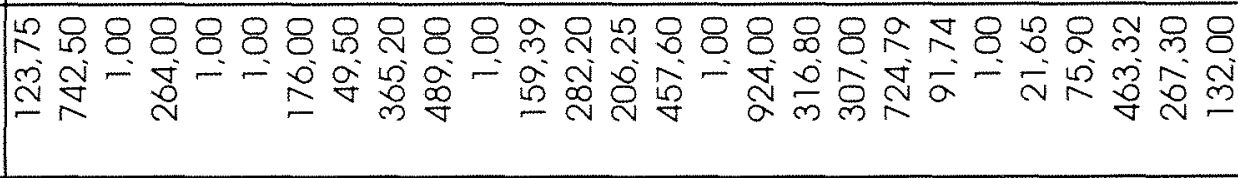 \\
\hline 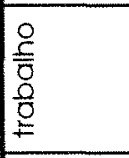 & $\because 2$ & 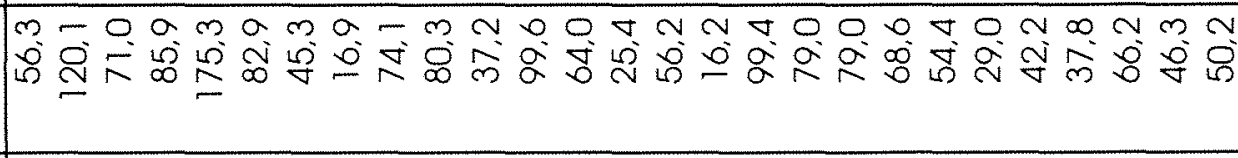 \\
\hline 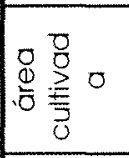 & 9 & 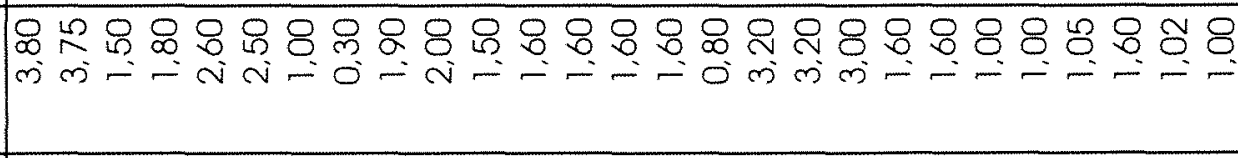 \\
\hline 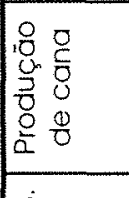 & 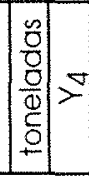 & 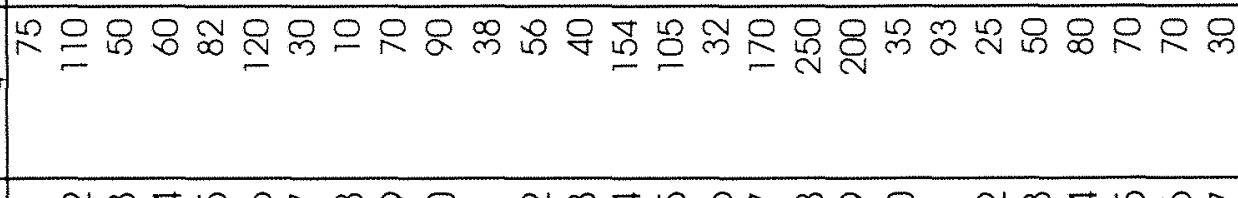 \\
\hline 㻤 & & 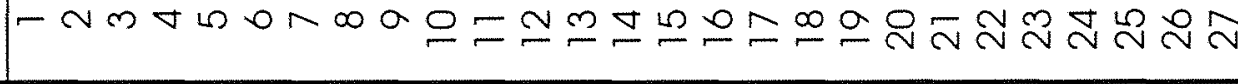 \\
\hline
\end{tabular}




\section{APÊNDICE 2}

Modelos testados nas estimativas das funções de produção 


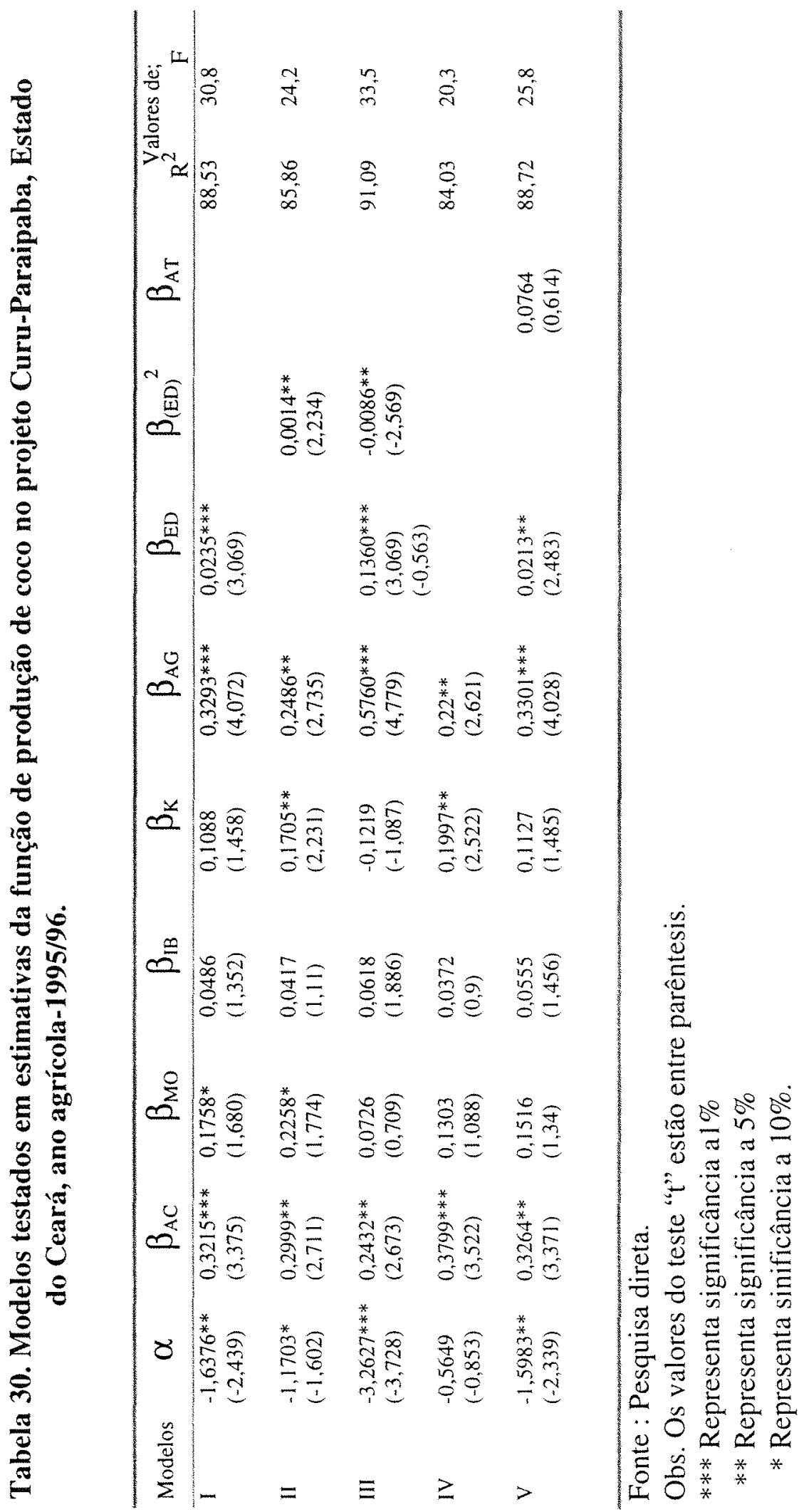




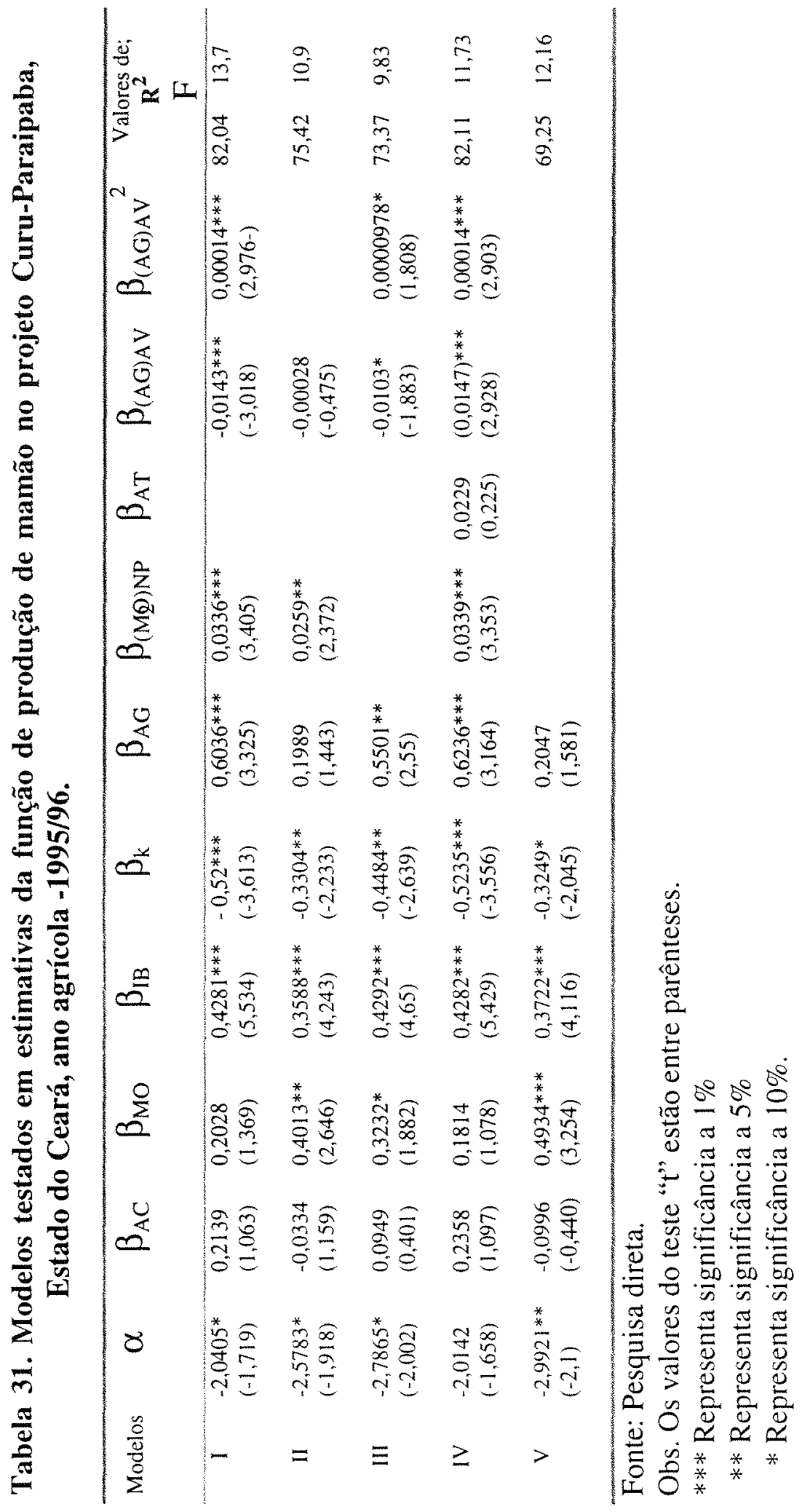




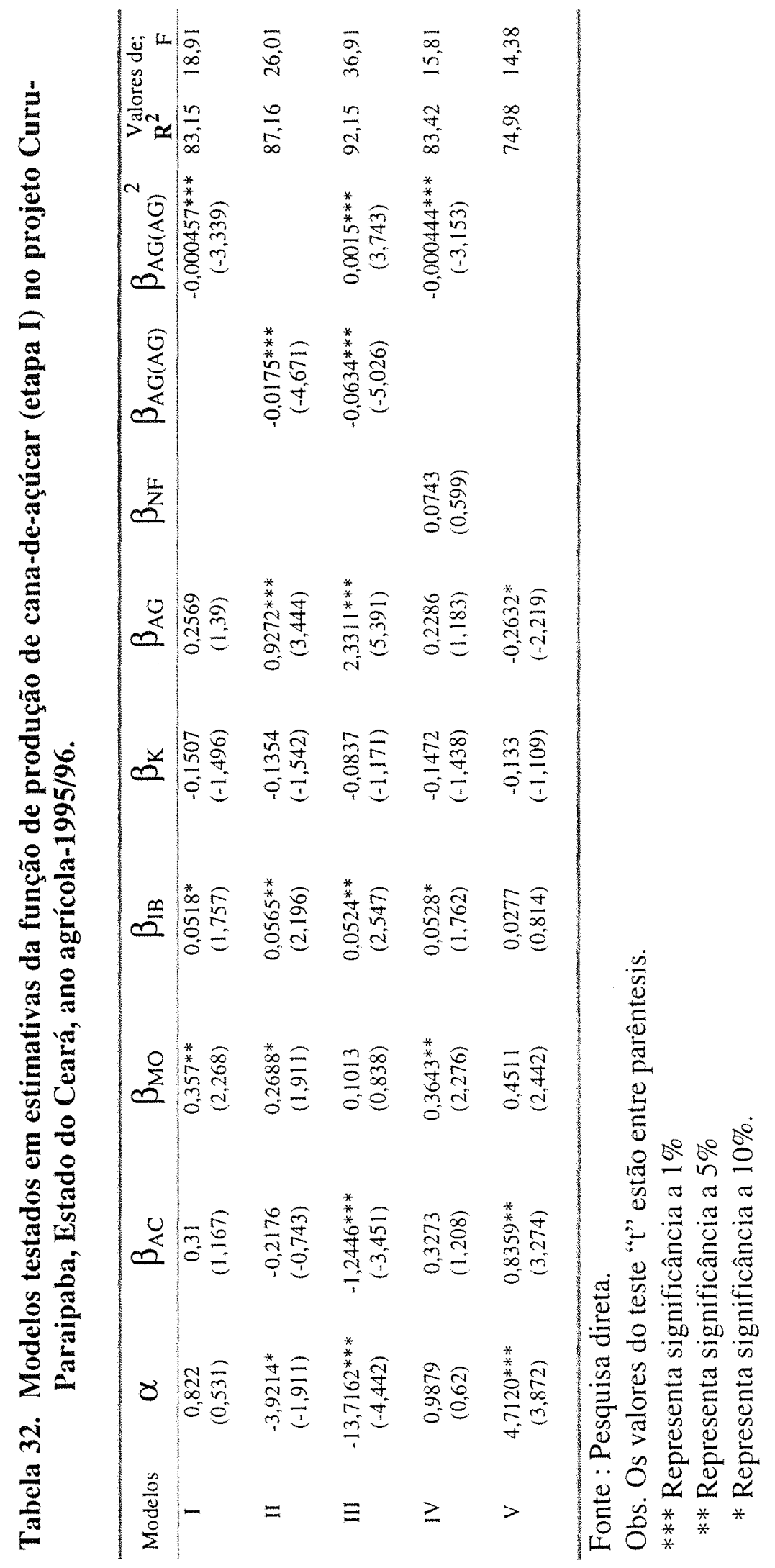




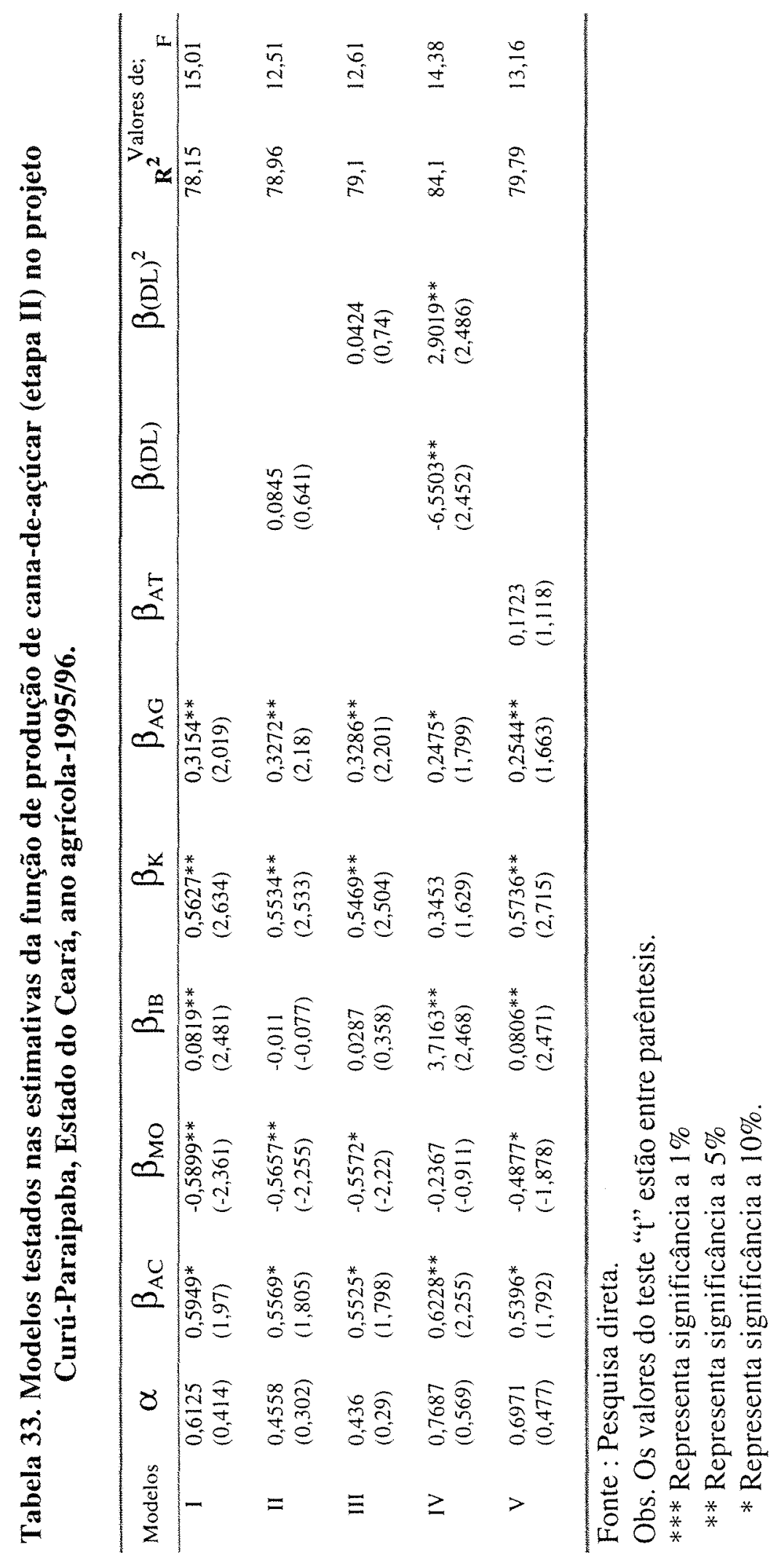


APÊNDICE 3

Testes e análises estatísticas utilizadas 
Tabela 34. Teste de Glejser para heterocedasticidade

\begin{tabular}{cccc}
\hline Produto & g.l & \multicolumn{2}{c}{ Valores de $\mathrm{X}^{2}(5 \%)$} \\
\hline coco & & Tabelados & Calculados \\
mamão & 6 & 12,50 & 1,759 \\
cana-de-açúcar (etapa I) & 6 & 15,51 & 7,763 \\
cana-de-açúcar (etapa I) & 5 & 12,50 & 10,872 \\
\hline
\end{tabular}

Fonte : Dados da pesquisa

Tabela 35. Diagnóstico de colinearidade.

\begin{tabular}{lccc}
\hline Produtos & \multicolumn{2}{c}{ Eigenvalues } & Condition number \\
& $\lambda_{\max }$ & $\lambda \min$ & $\left(\lambda_{\left.\max / \lambda_{\min }\right)^{1 / 2}}\right.$ \\
coco & 3,0146 & 0,2178 & 3,72 \\
mamão & 3,5149 & 0,1222 & 5,36 \\
cana-de-açúcar-etapa I & 3,0691 & 0,1621 & 4,35 \\
cana-de-açúcar-etapa II & 3,097 & 0,1222 & 5,03 \\
\hline
\end{tabular}

Fonte : Dados da pesquisa 


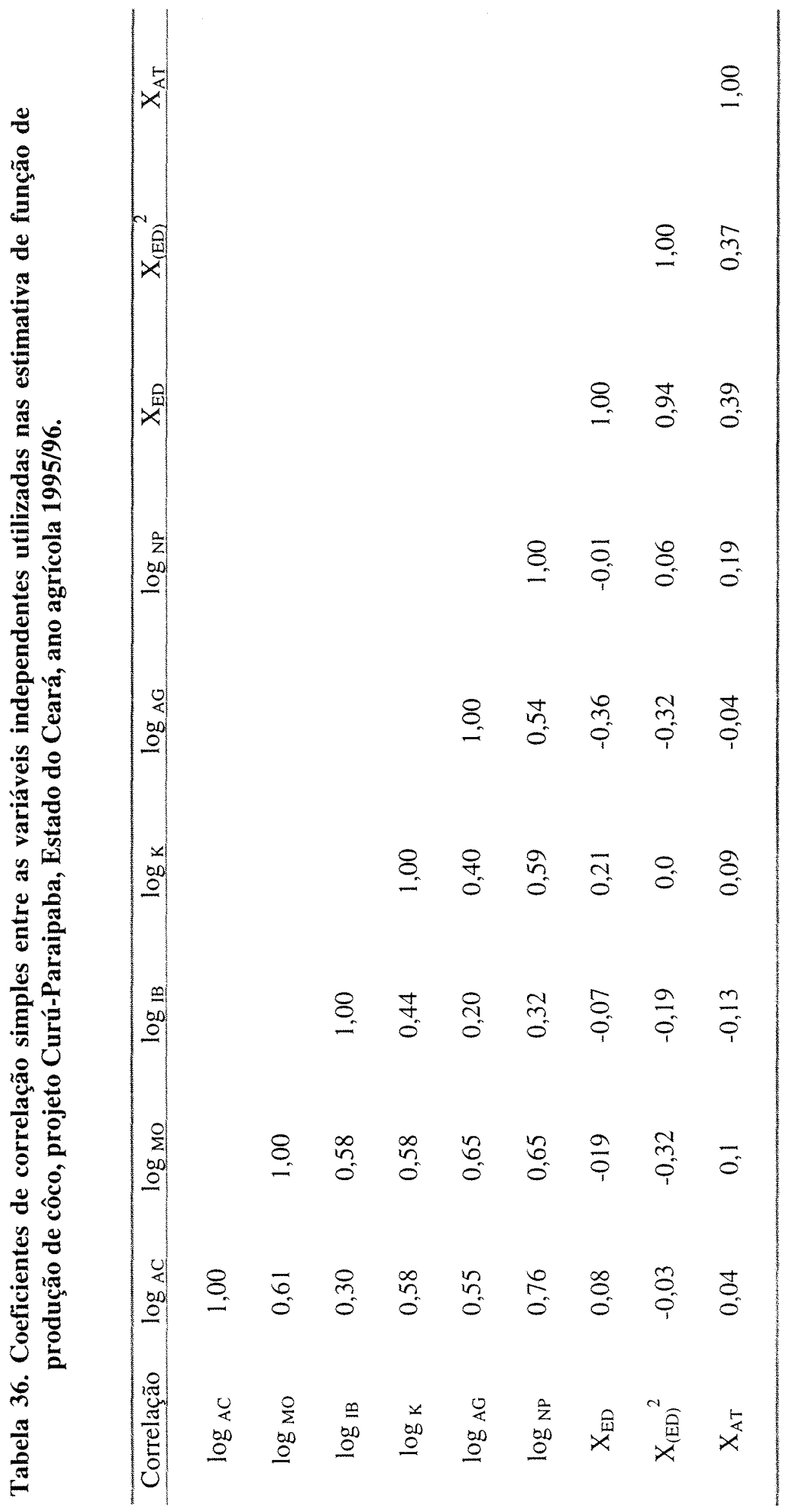




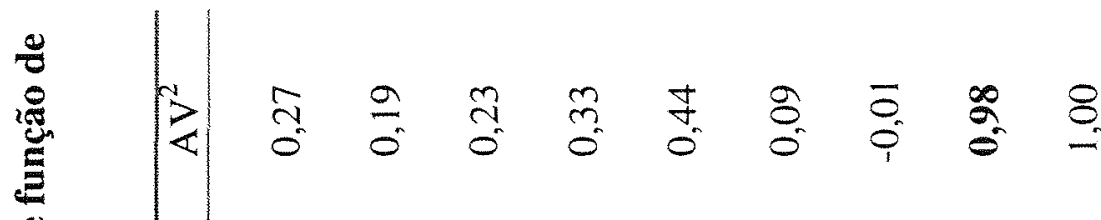

$\stackrel{5}{2}$

:

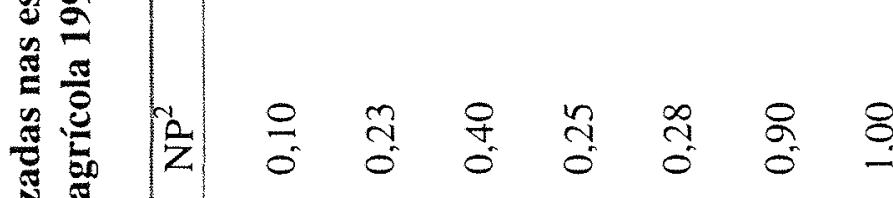

를

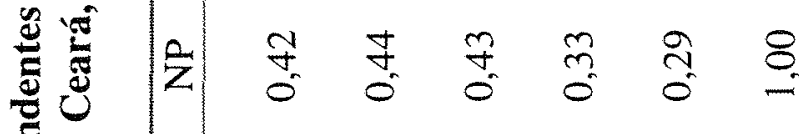

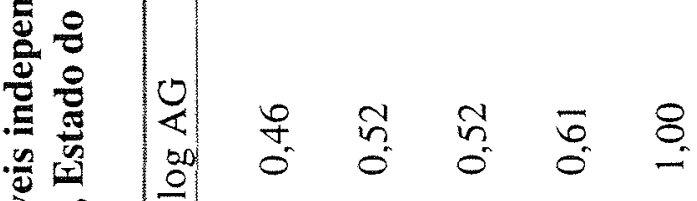

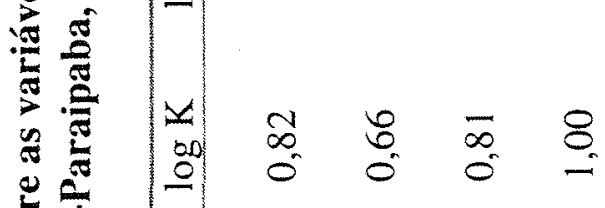

章

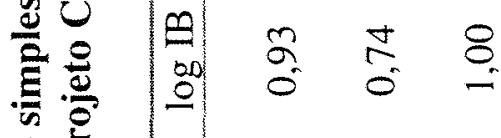

焉

ํํํ

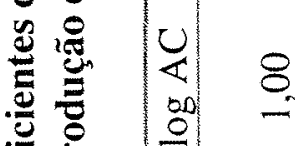

递窇

in

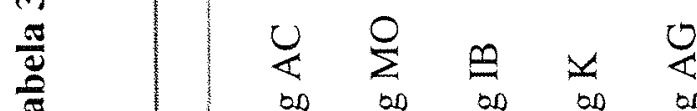

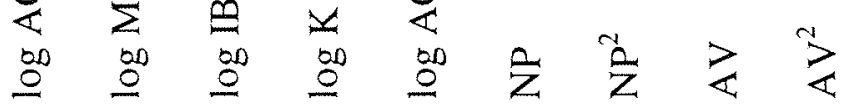


8

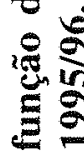

용

:

告

๘

$\stackrel{5}{3}$

雪

-

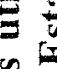

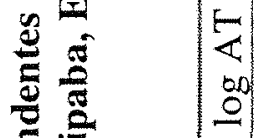

- $\stackrel{\infty}{j}_{0}^{\infty}$

- $\begin{array}{lll}8 & 0 & 0 \\ 0 & 0 & 0 \\ 0 & 0\end{array}$

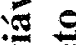

농

$\rightarrow$ 을

$\pi$

$\stackrel{0}{0}$

놀

ह

1ซึ

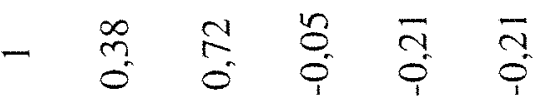

- $\begin{array}{llll}n & n & 0 & 0 \\ 0 & 0 & 0\end{array}$

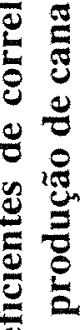

递

- $\begin{array}{cccccc}1 & \infty & 0 & 8 & 0 & 0 \\ 0 & 0 & 0 & 0 & 0\end{array}$

$\mid \begin{gathered}0 \\ \Sigma \\ 00 \\ 0\end{gathered}$

$\begin{aligned} & 0 \\ & 0 \\ & 0\end{aligned}-\begin{array}{lllllll}2 & \infty & 0 & 0 & 0 & \bar{j} & 0 \\ 0 & 0 & 0 & 0 & 0 & 0 & 0\end{array}$

$\infty$

$\frac{5}{0}$

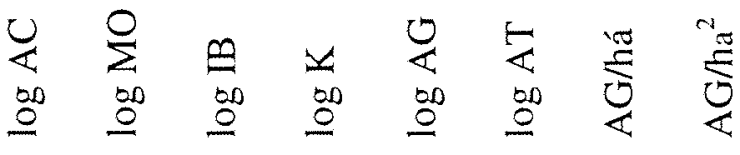


Tabela 39. Coeficientes de correlação simples entre as variáveis independentes utilizadas nas estimativa de função de produção de cana-de-açúcar (etapa II), projeto Curu-Paraipaba, Estado do Ceará, ano agrícola 1995/96.

\begin{tabular}{lccccc}
\hline & $\log \mathrm{AC}$ & $\log \mathrm{MO}$ & $\log \mathrm{BB}$ & $\log \mathrm{K}$ & $\log \mathrm{AG}$ \\
\hline $\log \mathrm{AC}$ & 1 & 0,77 & 0,24 & 0,84 & 0,55 \\
$\log \mathrm{MO}$ & 1 & 0,25 & 0,66 & 0,69 \\
$\log \mathrm{BB}$ & & 1 & 0,05 & 0,05 \\
$\log \mathrm{K}$ & & & 1 & 0,43 \\
$\log \mathrm{AG}$ & & & & 1 \\
\hline
\end{tabular}




\section{APÊNDICE 4}

Metodologia de cálculo do produto médio, do valor do produto marginal, e preços dos fatores e dos produtos. 
Cálculo do produto médio. (Pme) Com os dados da amostra de cada produto, soma-se a quantidade produzida $\left(\Sigma Y_{i}\right)$ e divide-se pela soma do fator $\left(\Sigma X_{j}\right)$. Então:

$$
\mathrm{P}_{\mathrm{me}}=\left(\Sigma \mathrm{Y}_{\mathrm{i}}\right) /\left(\Sigma \mathrm{X}_{\mathrm{j}}\right)
$$

Para se obter o valor do produto médio $\left(\mathrm{VPM}_{\mathrm{e}}\right)$, basta multiplicar $\mathrm{PM}_{\mathrm{e}}$ pelo preço do produto $P_{i}$

Cálculo do valor do produto marginal $\left(\mathrm{VPM}_{\mathrm{g}}\right)$. Para se obter o $\left(\mathrm{VPM}_{\mathrm{gxi}}\right)$. do fator $\mathrm{X}_{\mathrm{i}}$, basta multiplicar o $V_{P M}$ do fator $X_{i}$, pela elasticidade parcial de produção (obtida da função de produção) $e_{p}$ do fator $X_{i}$.

$$
\mathrm{Vpmg}_{\mathrm{xi}}=\mathrm{Vpme}_{\mathrm{xi}} \cdot \mathrm{e}_{\mathrm{p}}
$$

Os preços dos fatores e produtos considerados nos modelos analisados estão expressos em reais $(\mathrm{R} \$$ ) de dezembro de 1995 . Foram indicados com base nos seguintes critérios:

\section{Terra}

O DNOCS estipula que o valor do arrendamento de 1 ha na área do projeto é de $\mathrm{R} \$ 78,00$. Mas, o preço de mercado praticado nos arrendamentos, segundo a direção da Cooperativa dos Irrigantes era de R \$380,00/ha no ano agrícola de 1995/96. Trata-se de áreas sistematizadas e com disponibilidade dágua na época de verão, razão pela qual a média dos arrendamentos de terra no projeto ser bem superior ao valor cobrado na região.

\section{Trabalho}

O preço de um dia de trabalho (8 horas) de um homem adulto, em dezembro de 1995 , era $\mathrm{R} \$ 4,00$, segundo a Cooperativa dos Irrigantes.

Capital na forma de equipamentos de irrigação

O valor do capital foi determinado considerando o rendimento que cada unidade monetária aplicada nessa forma de capital proporcionaria ao irrigante. A taxa de juros em 1995 utilizada para remuneração deste capital foi fixada pela DIRGA/GAP- (Grupo de apoio a produção da diretoria de irrigação do DNOCS). Esta taxa é de 5,34 \% a.a. e o preço, desta forma de capital é igual a $\mathrm{R} \$ 1,0534$.

\section{Insumos básicos}

Da mesma forma, a taxa de juros utilizada para remuneração de insumos é fixada pela DIRGA/GAP- (Grupo de apoio a produção da diretoria de irrigação do DNOCS) em 9\% 
a.a. Esta seria a retribuição a cada unidade empregada em insumos. Então, o preço estimado para esta variável foi de $\mathrm{R} \$ 1,09$.

\section{$\underline{\text { Água }}$}

A tarifa dágua foi fixada através da Portaria Ministerial $n^{\circ} 18$, de 13/02/95, com vigência até $31 / 12 / 95$, no valor de $\mathrm{R} \$ 6,15 / 1000 \mathrm{~m}^{3}$. Uma cópia da Portaria encontra-se no apêndice. 17.

Produtos analisados

Preços fornecidos pela Cooperativa dos Irrigantes e praticados pelo mercado em dezembro de 1995, sendo: $\mathrm{R} \$ 200,00 /$ milheiro de coco, $\mathrm{R} \$ 147,30 /$ ton de mamão e $\mathrm{R} \$$ $18,00 /$ ton. de cana-de-açúcar. 
Apêndice 5

Cálculo do preço da água. 
Para o cálculo do preço da água, utilizou-se os preços dos produtos de duas maneiras. A primeira, os preços efetivamente recebidos pelos produtores em dezembro de 1995, no projeto Curu-Paraipaba, em dezembro de 1995. Toda a análise foi fundamentada neste período.

\section{demonstracão}

$$
\begin{aligned}
& \text { Sejam } p=14 \cdot 091,42 .(A G) c^{-0,7514} ; p=2 \cdot 571,54 .(A G) m^{-0,7614} \\
& \left.p=7 \cdot 933,87 .(A G) \mathrm{ca}_{1}{ }^{-0,7656} \text { e } p=2 \cdot 651,7 . A G\right) \mathrm{ca}_{2}{ }^{-0,6846}
\end{aligned}
$$

onde: $p$ é o preço da água e $(A G) c,(A G) m,(A G) c a_{1}$ e $(A G) c a_{2}$ são respectivamente quantidades demandadas de água para coco, mamão e para cana-deaçúcar das etapas I e II.

Então;

$(A G) c^{-0,7514}=p / 14.091,42 ;(A G) m^{-0,7614}=p / 2.571,54 ;$

$(\mathrm{AG}) \mathrm{ca}_{1}{ }^{-0,7656}=\mathrm{p} / 7.933,87$ e $(\mathrm{AG}) \mathrm{ca}_{2}{ }^{-0,6846}=\mathrm{p} / 2.651,7$.

Mudando o sinal dos expoentes, fica;

$(\mathrm{AG}) \mathrm{c}^{0,7514}=14.091,42 / \mathrm{p} ;(\mathrm{AG}) \mathrm{m}^{0,7614}=2.571,54 / \mathrm{p} ;$

$(\mathrm{AG}) \mathrm{ca}_{1}{ }^{0,7656}=7.933,87 / \mathrm{p}$ e $(\mathrm{AG}) \mathrm{ca}_{2}{ }^{0,6846}=2.651,7 / \mathrm{p}$.

Transferindo os expoentes para o segundo membro das equações acima, tem-se:

$(\mathrm{AG}) \mathrm{c}=14.091,42^{1,3308} / \mathrm{p}^{1,3308} ;(\mathrm{AG}) \mathrm{m}=2.571,54^{1,3134} / \mathrm{p}^{1,3134} ;$

$(\mathrm{AG}) \mathrm{ca}_{1}=7.933,87^{1,3062} / \mathrm{p}^{1,3062}$ e $(\mathrm{AG}) \mathrm{ca}_{2}=2.651,7^{1,4607} / \mathrm{p}^{1,4607}$.

Sabendo que $(A G) c+(A G) m+(A G) c_{1}+(A G) c_{2}=8.284,5 \mathrm{mil} \mathrm{m}^{3}$, pode-se formar a equação:

$$
\begin{aligned}
& 322.222,46 / \mathrm{p}^{1,3308}+30.126,57 / \mathrm{p}^{1,3134}+124.024,61 / \mathrm{p}^{1,3062}+ \\
& 100.171,24 / \mathrm{p}^{1,4607}=8.284 .500
\end{aligned}
$$

A igualdade é atendida quando $p=R \$ 140,61 / \mathrm{mil} \mathrm{m}^{3}$. 
A segunda maneira de se estimar os preço da água foi por simulação, considerando os preços dos produtos da tabela 40. Esses preços são referentes ao período de julho de 1994 a março de 1998.

Tabela 40. Preço máximo, mínimo, e médio mensal do coco, mamão e cana-deaçúcar, recebidos pelos produtores do projeto Curu-Paraipaba no período de julho de 1994 a março de 1998.

\begin{tabular}{lcccc}
\hline Produto & Unidade & \multicolumn{3}{c}{ Preços dos Produtos (R\$/unid.) } \\
\cline { 3 - 5 } & & máximo & mínimo & médio mensal \\
\hline coco & milheiro & 307,40 & 190,52 & 247,70 \\
mamão & ton & 180,62 & 126,60 & 150,60 \\
cana-de-açúcar & ton & 19,02 & 14,49 & 16,33 \\
\hline
\end{tabular}

Fonte: EMATERCE

Nota: Os preços máximos e mínimos dos produtos, são representados respectivamente pelas máximas e mínimas médias mensais de cada ano no período analisado. 
Apêndice 6

Cálculo das elasticidades preços da água $\left(\mathrm{e}_{\mathrm{p}}\right)$. 
A forma algébrica das equações de demanda dágua é:

$\mathrm{P}=A X^{-\beta}$

onde: $\mathrm{X}^{\beta}=\frac{\mathrm{P}}{\mathrm{A}}$, que pode também ser escrito $\mathrm{X}^{\beta}=\frac{A}{P}$. Elevando ambos os membros $\mathrm{a} \frac{1}{\beta}$, fica: $\mathrm{X}=\left(\frac{\mathrm{A}}{\mathrm{P}}\right)^{\frac{1}{\beta}}$

Calculando-se a derivada de $\mathrm{X}$ em relação a $\mathrm{P}$, tem-se:

$\left(\frac{\partial X}{\partial P}\right)=\frac{-1}{\beta} A^{\frac{1}{\beta}} \cdot P^{\frac{-1}{\beta-1}} ;$ agora multiplicando-se ambos os membros por $\frac{\mathrm{P}}{\mathrm{X}}$, tem-

se:

$$
\frac{\partial \mathrm{X}}{\partial \mathrm{P}} \cdot \frac{\mathrm{P}}{\mathrm{X}}=\frac{-1}{\beta} A^{\frac{1}{\beta}} \cdot P^{\frac{-1}{\beta}-1} \cdot \frac{P}{\mathrm{X}}
$$

Substituindo-se $\mathrm{X}$ por $\left(\frac{\mathrm{A}}{\mathrm{P}}\right)^{\frac{1}{\beta}}$, e sabendo-se que $\left(\frac{\mathrm{A}}{\mathrm{P}}\right)^{\frac{1}{\beta}}=\mathrm{A}^{\frac{1}{\beta}} \cdot P^{\frac{-1}{\beta}}$ fica:

$$
\frac{\partial X}{\partial P} \cdot \frac{P}{X}=\frac{\frac{-1}{\beta} A^{\frac{1}{\beta}} \cdot P^{\frac{-1}{\beta}-1} P^{\frac{1}{\beta}} \cdot P}{A^{\frac{1}{\beta}}}
$$

Então $\mathrm{e}_{\mathrm{p}}=-\frac{1}{\beta}$

Verifica-se que a elasticidade preço da água é constante.

Tomando-se os valores de $\beta$ das equações de demanda dágua, tem-se:

$-1,3308,-1,3134,-1,3062$ e $-1,4607$, que são as elasticidades preços da demanda, respectivamente, para coco, mamão e cana-de-açúcar na etapa I e II do projeto Curu-Paraipaba. 
Apêndice 7

Cálculo da disposição a pagar (DAP) por água. 
A área situada abaixo da curva da demanda dágua, cuja quantidade demandada varia de zero até a quantidade ótima determinada pelo preço de $\mathrm{R} \$ 140,61$ $11000 \mathrm{~m}^{3}$ menos os custos fixos, é, por definição, a disposição a pagar (DAP*) por água. Como a curva da demanda é uma hipérbole generalizada, que não corta os eixos, trata-se de uma integral imprópria. Isto ocorre quando o integrando tem uma descontinuidade infinita no limite inferior de integração.

Se $\mathrm{f}$ for contínua em todo $\mathrm{X}$ do intervalo semi-aberto à esquerda $(\mathrm{a}, \mathrm{b})$ e se:

$\lim _{x \rightarrow a^{+}} f(x)= \pm \infty$

então: $\quad \int_{a}^{b} f(x) d x=\lim _{g \rightarrow 0^{+}} \int_{a+g}^{b} f(x) d x$

Se o limite inferior existir.

Se é possível especificar um número finito que represente a área abaixo das curvas de demanda de água, será as integrais impróprias.

Exemplo da cultura do coco: $P=14.091,42 X^{-0,7514}$;

onde: $\quad \int_{0}^{4.521 .100} 14.091,42 X^{-0.7514} d x=\lim _{s \rightarrow 0} \int_{s}^{4.521 .100} 14.091,42 X^{-0.7514} d x$

então; $\left.\quad \lim _{s \rightarrow 0} 56.683,1 X^{0.2486}\right]_{0}^{4.521 .100}=2.558 .275,3$

Esta área situada abaixo da curva da demanda (2.558.275,3), equivale ao valor bruto da produção (VBP) de coco. Subtraindo do VBP os custos fixos 169,2 mil), obtém-se o valor de $\mathbf{R} \$ 2.389,1$ mil, que representa a disposição a pagar pela água (DAP) a preços de dezembro de 1995, destinada ao côco.

Utilizando o mesmo procedimento para as demais culturas, efetuou-se os registros na tabela 22 da DAP por água. 
Apêndice 8

Portaria $\mathrm{N}^{0}$ 18, de 13 de fevereiro de 1995, do Ministério do Meio Ambiente, dos Recursos Hídricos e da Amazônia Legal. 


\section{Ministério do Meio Ambiente, dos Recursos Hídricos e da Amazônia Legal}

\section{GABINETE DO MINISTRO}

PORTARIA NQ 18, DE 13 DE FEVEREIRO DE 1995

O MINISTRO DE BSTADO DO MEIO AMBIENTB, DOS RECURSOS HIDRICOS $B$ DA AMAZÔNIA LEGAL, no uso de suas atribuiçbes que the confere o art. 87. inciso.II, da Constituiçāo, e tendo em vista o art. ". inciso VII, da Lei $n^{*} 6.662$, de 25 de junho de 1979 , combinado com $0^{\prime}$ art. $4^{\circ}$ da Lei $n: 7.739$, de 26 de marco de 1989, bem como o disposto no art. 43, 5 4*, do Decreto $n^{*} 89.496$, de 29 de marco de 1984, RBSOLVB:

Art. 1. Pixar as Tarifas Diagua para as areas jurisdicionadas ao Departamento Nacional de Obras Contra as secas DNOCS, conforme os valores discriminados nos QUADROS 1 e 2 constantes do Anexo desta portaria, com vigéncia ate 31 de dezembro de 1995.

Parágrafo único. o pagamento da tarifa d'água pelo usuario. fora da data do vencimento, implicará na cobrança dos acréscimos legais, nos termos da legislaçăo e cláusulas contratuais vigentes.

Art. 2* Autorizar ao DNOCS celebrar acordos especsficos zom as Organizaços de Irrigantes, visando permitir que estas arrecadem dos usuários dos sistemas de irrigacão dos perfmetros as importáncias relativas a Tarifa D'água e utilizem as receitas correspondentes aos volumes fornecidos para fins de irrigacão pública e outros usos, exclusivamente na execuçáo das atividades de administraça, operaça e

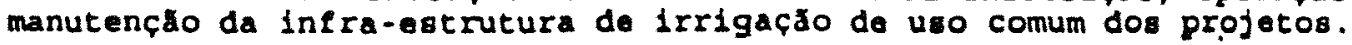
publicacáo.

Art. 3* A presente portaria entra en vigor na data de sua 
TAEELA DE VALORES DAS TARTPAS D hGUA DOS DNOCS COM VIGENCWA ATE 31 DE DE JEMBRO DE 1995

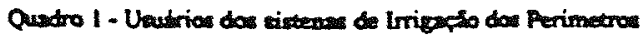

\begin{tabular}{|c|c|c|c|c|}
\hline \multirow{2}{*}{$\begin{array}{c}\text { DN } \\
\text { DERUR } \\
\text { Exdo }\end{array}$} & \multirow{2}{*}{ PeratMETRO } & \multicolumn{2}{|l|}{ DRRGAÇAO } & \multirow{2}{*}{$\begin{array}{c}\text { Outros } \\
\text { (RS/2000 min }\end{array}$} \\
\hline & & $\begin{array}{l}\text { Parcele } K_{1}{ }^{\prime \prime} \\
\text { (nshs/2no) }\end{array}$ & $\begin{array}{l}\text { Percele } K^{2} \\
\text { (Rs/1000m) }\end{array}$ & \\
\hline $\begin{array}{c}I^{\circ} \mathrm{DR} \\
\mathrm{P}\end{array}$ & $\begin{array}{l}\text { CALDERIO } \\
\text { FDALOO } \\
\text { GURGUELA } \\
\text { LAGOAS DO PUAU }\end{array}$ & $\begin{array}{r}12.70 \\
37.93 \\
4275 \\
23,58 \\
\end{array}$ & $\begin{array}{l}12,53 \\
8.74 \\
6.24 \\
9.87 \\
\end{array}$ & $\begin{array}{l}14,41 \\
10,05 \\
7,18 \\
11,35 \\
\end{array}$ \\
\hline FDR & 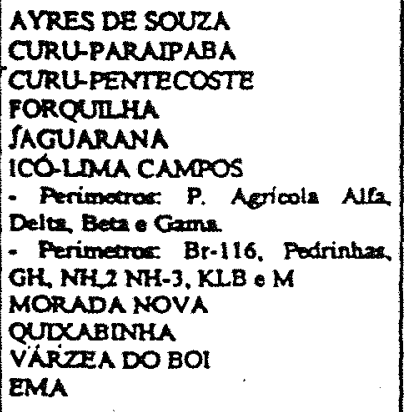 & $\begin{array}{l}30.28 \\
28.55 \\
29.23 \\
28.89 \\
30.16 \\
\\
19.79 \\
19.79 \\
23.96 \\
13.84 \\
41.28 \\
27.46\end{array}$ & $\begin{array}{l}7.25 \\
6.15 \\
3.06 \\
8.24 \\
8,15 \\
\\
3.45 \\
\\
8.10 \\
3,15 \\
15.66 \\
4,50 \\
7.63\end{array}$ & $\begin{array}{c}8.34 \\
7.07 \\
3.52 \\
9.48 \\
9.37 \\
\\
6.27 \\
\\
9.32 \\
3,62 \\
18.01 \\
5.18 \\
8.77\end{array}$ \\
\hline $\begin{array}{r}\text { Y DR } \\
\mathrm{PZ}\end{array}$ & $\begin{array}{l}\text { BOA VISTA } \\
\text { CACHOERA II } \\
\text { CUSTOOUA } \\
\text { MOXOTO }\end{array}$ & $\begin{array}{l}14.84 \\
3.26 \\
12.96 \\
12.56\end{array}$ & $\begin{array}{l}11,02 \\
5,81 \\
13,68 \\
13,26\end{array}$ & $\begin{array}{l}12,67 \\
6,68 \\
15,73 \\
15,25\end{array}$ \\
\hline $\begin{array}{l}A^{\circ} \mathrm{DR} \\
\mathrm{BA}\end{array}$ & $\begin{array}{l}\text { BRUMUDO } \\
\text { VAZA BARRIS } \\
\text { IACURICI } \\
\end{array}$ & $\begin{array}{l}5299 \\
31.25 \\
12.32\end{array}$ & $\begin{array}{l}2,50 \\
5,38 \\
6,31\end{array}$ & $\begin{array}{l}2.88 \\
6.18 \\
726\end{array}$ \\
\hline $\begin{array}{l}\text { I' DERUR } \\
\text { RN }\end{array}$ & 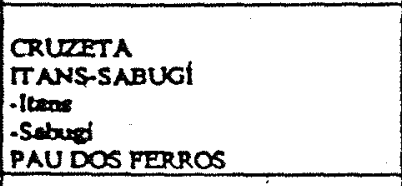 & $\begin{array}{l}24.61 \\
24.95 \\
24,95 \\
28.33\end{array}$ & $\begin{array}{l}5,38 \\
5,80 \\
7,74 \\
4,43\end{array}$ & $\begin{array}{l}6,19 \\
6,68 \\
3,90 \\
5,09\end{array}$ \\
\hline $\begin{array}{c}\text { Y DERUR } \\
\text { PB }\end{array}$ & $\begin{array}{l}\text { ENG ARCOVERDE } \\
\text { SAO GONCALO } \\
\text { SUME }\end{array}$ & $\begin{array}{l}19,24 \\
12,84 \\
14,20\end{array}$ & $\begin{array}{l}10,40 \\
7,14 \\
11,98\end{array}$ & $\begin{array}{l}11.96 \\
8.21 \\
13,72\end{array}$ \\
\hline
\end{tabular}

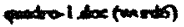

(1) Valor e ex cobrado para cada hectare irrigavel do lote

(2) Outros Usos: Irrigaço Privad; Abastecimento de Centros drbanose Industrials; etc.

QUADRO 2 - Outro Usuario

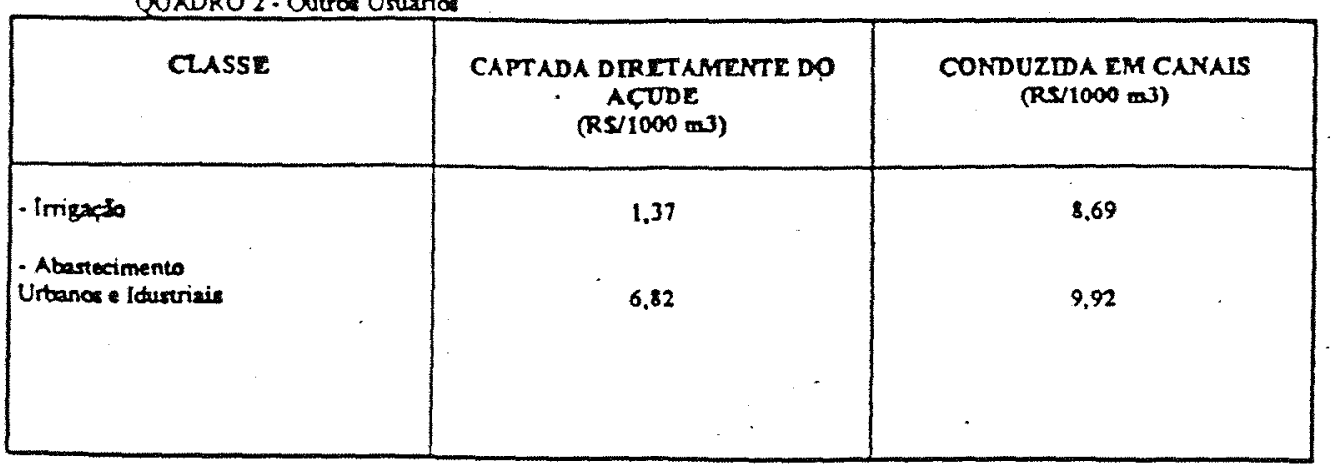


Apêndice 9

Modelo do questionário aplicado no projeto Curu-Paraipaba. 
Código do produtor Nome

Endereço

1. Área e produção:

Área irrigada total

ha: Área irrigada colhida da linha de exploração ha.

Produção efetivamente colhida: Quantidade

Unidade

Ano de implantação da cultura

Espacamento utilizado $N^{\circ}$ de safras já obtidas Variedade $n^{\circ}$ de plantas

2. Măo-de-obra: Quantidade por operaçōes, por faixa etária e por sexo( $\left.{ }^{\star}\right)$

\begin{tabular}{|l|l|l|l|l|l|l|l|l|l|l|}
\hline Quantidade(HD) & $10-15$ anos & \multicolumn{2}{l|}{$15-20$ anos } & \multicolumn{2}{|l|}{$20-60$ anos } & \multicolumn{2}{l|}{60 anos } & Total \\
\hline Operaçðes & masc. & fem. & masc. & fem. & masc. & fem. & masc & fem. & \\
\hline adubacão & & & & & & & & & \\
\hline Tratos fitossanit. & & & & & & & & & \\
\hline irrigação & & & & & & & & & \\
\hline capinas & & & & & & & & & \\
\hline corte (colheita) & & & & & & & & & \\
\hline Outros & & & & & & & & & \\
\hline total & & & & & & & & & \\
\hline
\end{tabular}

(*) Força de trabalho padrão (20-60 anos). De 10 a 15 anos(50\%) e de $15-20$ anos e com > de 60 anos, $(80 \%)$ da força de trabalho padrão.

3. Quantidade de insumos por mês, crédito e outras informações relevantes, relacionadas apenas com a linha de exploração.

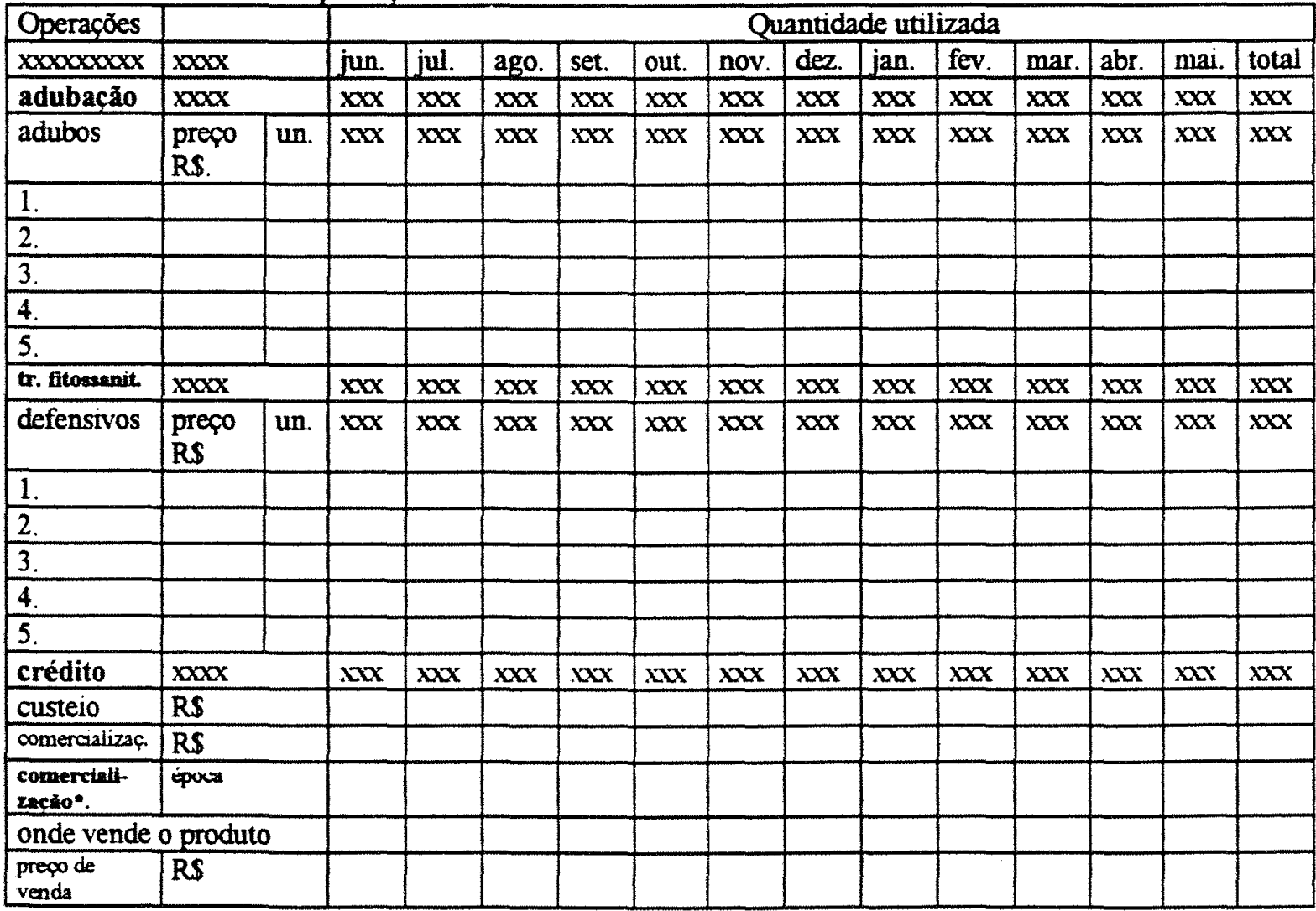

* marque um X nos meses em que comercializa o produto 
-4. Capital (utilizado total ou parciamente na linha de exploração)

\begin{tabular}{l}
\hline 4.1. Motobombas \\
\begin{tabular}{|l|l|l|l|l|l|l|}
\hline conj. & marca & Alt. manométrica & potência-HP & vazão-m $\mathrm{m}^{3} / \mathrm{h}$ & v.reposição RS & vida útil \\
\hline 1 & & & & & & \\
\hline 3 & & & & & & \\
\hline 3 & & & & & & \\
\hline 5 & & & & & & \\
\hline
\end{tabular}
\end{tabular}

\subsection{Tipo de irrigação}

$\square$ por sulco: preencher (4.2.1) $\square$ por aspersão convencional: preencher (4.2.2)

4.2.1. Irrigação por sulco ( exclusivamente na linha de exploraça ).

\begin{tabular}{|l|l|l|l|l|}
\hline num. de sulcos & comp./médio & comprimento total $-\mathrm{m}$ & preco do metro.RS & custo total RS \\
\hline & & & &
\end{tabular}

\subsubsection{Irrigaçăo por aspersão}

\subsubsection{Acessórios}

\begin{tabular}{|l|l|l|l|l|l|}
\hline Itcns & unidade & quantidade & vida útil-anos & $\begin{array}{l}\text { preço unit. } \\
\text { RS }\end{array}$ & valor total-RS \\
\hline curvas & & & & & \\
\hline tampão final & & & & & \\
\hline derivação T & & & & & \\
\hline cotovelos de derivação & & & & & \\
\hline registro de gaveta & & & & & \\
\hline tubo de subida com tripe & & & & & \\
\hline manômetros & & & & & \\
\hline braçadeiras & & & & & \\
\hline aspersores(1 bocal) & & & & & \\
\hline aspersores(2 bocais) & & & & & \\
\hline & & & & & \\
\hline & & & & & \\
\hline
\end{tabular}

\subsubsection{Tubulações}

\begin{tabular}{|l|l|l|l|l|l|}
\hline Linhas & mat.usado* & comprimento-m & vida útil-anos & preco unit.RS & valor-RS \\
\hline principais & & & & & \\
\hline principais móveis & & & & & \\
\hline secundárias & & & & & \\
\hline laterais & & & & & \\
\hline & & & & & \\
\hline & & & & & \\
\hline & & & & & \\
\hline total & & & & & \\
\hline
\end{tabular}

* utilizar para linha principal e secundária: 1- ferro fundido, 2 - aço, 3 - cimento, 4 - amiantoo, 5 - concreto, 6 - aço zincado, 7 - aluminio, 8 - PVC rigido. Utilizar para linha lateral e principais móveis: 8 - aço zincado. 9 - alumínio, 10 - PVC rigido com engate rápido. 
5. Água-, (utilizada na linha de exploração).

5.1. Indique em termos percentuais os meses que faz irrigação:

\begin{tabular}{|l|l|l|l|l|l|l|l|l|}
\hline junho & julho & agosto & setemb & ourubro & novemb & dezemb & janeiro & fevereiro \\
\hline & & & & & & & & \\
\hline
\end{tabular}

\subsection{Marque o numero de horas nos dias sucessivos necessários para completar} uma irrigação na linha de exploração: (Turno de rega)

\begin{tabular}{|l|l|l|l|l|l|}
\hline dias da semana & \multicolumn{2}{|c|}{ no lote - número de: } & \multicolumn{2}{c|}{ no quinfal- número } \\
\hline & horas & aspersores & horas & aspersores \\
\hline segunda-feira & & & & \\
\hline terca-feira & & & & \\
\hline quarta-feira & & & & \\
\hline quinta-feira & & & & \\
\hline sexta-feira & & & & \\
\hline sábado & & & & \\
\hline domingo & & & & \\
\hline & & & & \\
\hline segunda-feira & & & & \\
\hline terca-feira & & & & \\
\hline quarta-feira & & & & \\
\hline quinta-feira & & & & \\
\hline sexta-feira & & & & \\
\hline sábado & & & & \\
\hline domingo & & & & \\
\hline
\end{tabular}

5.3. Vazão de entrada nos sulcos - 1/seg.(apenas para quem responder o ítem 4.2.1).

\begin{tabular}{|l|l|l|l|l|l|l|l|l|l|l|}
\hline V.e. & junho & julho & agosto & setembro & outubro & novembro & dezembro & janeiro & fevereiro & total \\
\hline I/s & & & & & & & & & & \\
\hline
\end{tabular}

5.4. Tabela para calcular o número de dias de irrigação em todo o ano agrícola

\begin{tabular}{|l|r|r|r|r|r|r|r|}
\hline & sexta-feira & sábado & \multicolumn{1}{l|}{ segunda } & \multicolumn{1}{l|}{ terca-feira } & quarta-feira & quinta-feira & total \\
\hline meses & & \multicolumn{3}{|c|}{ NUMERO DE DIAS } & & & \\
\hline julho & 5 & 5 & 4 & 4 & 4 & 4 & 26 \\
\hline agosto & 4 & 4 & 5 & 5 & 5 & 4 & 27 \\
\hline setembro & 5 & 4 & 4 & 4 & 4 & 5 & 26 \\
\hline outubro & 4 & 5 & 5 & 4 & 4 & 4 & 26 \\
\hline novembro & 4 & 4 & 4 & 5 & 5 & 4 & 26 \\
\hline dezembro & 5 & 5 & 4 & 4 & 4 & 5 & 27 \\
\hline janeiro & 4 & 4 & 5 & 5 & 4 & 4 & 26 \\
\hline fevereiro & 4 & 4 & 4 & 4 & 5 & 4 & 25 \\
\hline total & 35 & 35 & 35 & 35 & 35 & 34 & 209 \\
\hline
\end{tabular}


5.5. Vazão - (Quantidade de água por unidade de tempo)

\begin{tabular}{|c|c|c|c|c|c|c|c|c|c|}
\hline $\mathrm{N}^{\circ}$ de Aspersores & persores. & \multicolumn{4}{|c|}{ Vazão dos aspersores - $1 /$ seg. } & \multirow{2}{*}{\multicolumn{4}{|c|}{$\begin{array}{l}\text { quantidade de áqua utilizada na irrigaçao } \\
\text { metro cúbico }\left(\mathrm{m}^{3}\right)\end{array}$}} \\
\hline \multirow[t]{2}{*}{ quintal } & \multirow[t]{2}{*}{ lote } & \multirow{2}{*}{$\begin{array}{l}\text { quint } \\
\text { al } \\
1^{\circ}\end{array}$} & \multirow{2}{*}{\begin{tabular}{|l|} 
bicos \\
$\mathrm{N}^{\circ}$ \\
\end{tabular}} & \multirow{2}{*}{\begin{tabular}{|l|} 
lote \\
$1^{\circ}$ \\
\end{tabular}} & \multirow[t]{2}{*}{ bicos $\mathrm{N}$} & & & & \\
\hline & & & & & & dias/ano & 1 & $=$ & \\
\hline & & $2^{\circ}$ & & $2^{\circ}$ & & horas/dia & 2 & $=$ & \\
\hline & & $3^{\circ}$ & & $3^{\circ}$ & & horas/ano & $\overline{3}$ & $1 \times 2$ & \\
\hline & & $4^{\circ}$ & & $4^{\circ}$ & & $1 / \operatorname{seg}$ & 4 & $=$ & \\
\hline & & $5^{\circ}$ & & $5^{\circ}$ & & $m^{3} /$ hora & 5 & $3.6 \times 4$ & \\
\hline & & $6^{\circ}$ & & $6^{\circ}$ & & $\mathrm{m}^{3} / \mathrm{ano}$ & 6 & $3 \times 5$ & \\
\hline & & $7^{\circ}$ & & $7^{\circ}$ & & & & & \\
\hline & & $8^{\circ}$ & & $8^{\circ}$ & & & & & \\
\hline & & $9^{\circ}$ & & $9^{\circ}$ & & & & & \\
\hline & & $10^{\circ}$ & & $10^{\circ}$ & & & & & \\
\hline & & & & & & & & & \\
\hline
\end{tabular}

\section{Observaçöes:}

